\title{
BATOLITO DE MOGOTES
}

\Cordillera Oriental Departamento de Santander

Ana María Correa Martínez, Gabriel Rodríguez, María Isabel Arango, Gilberto Zapata y José Gilberto Bermúdez

Catálogo de las unidades litoestratigráficas de Colombia / Triásico-Jurásico

Citación: Correa Martínez, A. M., Rodríguez, G., Arango, M. I., Zapata, G. y Bermúdez, J. G. (2020). Batolito de Mogotes. En Catálogos de las unidades litoestratigráficas de Colombia: Macizo de Santander. Vol. 1. Servicio Geológico Colombiano. https://doi.org/10.32685/9789585279445.1 
La actividad magmática del periodo Triásico tardío-Jurásico en el Macizo de Santander queda en evidencia por el emplazamiento de cuerpos intrusivos graníticos, cuerpos hipoabisales y vulcanismo riolítico-riodacítico en basamento metamórfico del Paleozoico (Ward et al., 1973; Van der Lelij, 2013). Los cuerpos son alargados y con dirección preferencial norte-noroeste, que es concordante con el rumbo de las fallas regionales, principalmente la falla de Bucaramanga, que marcan la tectónica del Macizo de Santander y delimitan las diferentes unidades geológicas.

La unidad Batolito de Mogotes es uno de los cuerpos intrusivos graníticos resultantes del magmatismo del Triásico-Jurásico en el Macizo de Santander. En el catálogo del Batolito de Mogotes, a partir de diferentes muestras del mismo que fueron obtenidas en el proyecto de investigación denominado "Magmatismo jurásico del Macizo de Santander", se presentan descripciones generales de campo, análisis petrográficos, de química mineral, resultados geoquímicos y geocronológicos U-Pb en circón por LA-ICP-MS. Este proyecto hace parte del macroproyecto "Magmatismo jurásico en Colombia", llevado a cabo por el grupo de estudios geológicos especiales de la regional Medellín del Servicio Geológico Colombiano, cuyo objeto es caracterizar geológicamente las principales unidades jurásicas de Colombia como un aporte al conocimiento geológico del país.

\section{Proponente del nombre}

El nombre de la unidad fue propuesto por Ward et al. (1973) en la memoria de los cuadrángulos H-1 2 y H-13.

Goldsmith et al. (1971) usaron el nombre Batolito de Mogotes en su trabajo sobre edades radiométricas en el Macizo de Santander, pero no hicieron ninguna definición de la unidad.

En este trabajo se conserva el nombre, ya que es un plutón con más de $100 \mathrm{~km}^{2}$ que cumple con la definición de batolito y la denominación se ajusta a las recomendaciones de la International Subcommission on Stratigraphic Classification of IUGS (1987, 1994). La diferencia con la definición original es que Ward et al. (1973) clasificaron la roca predominante como una cuarzomonzonita según el esquema de clasificación de rocas disponible en esa época, que era el de Travis (1955) y de acuerdo con la clasificación actual el nombre correcto para ese litotipo es monzogranito. Además, aunque predominan los monzogranitos, también se encuentran otros litotipos, como granodioritas.

\section{Origen del nombre y distribución geográfica}

\subsection{Origen del nombre}

El nombre asignado a la unidad en este catálogo es el mismo dado por Goldsmith et al. (1971) y Ward et al. (1973). La unidad toma el nombre del municipio de Mogotes, (Santander), localizado al sur de Bucaramanga, en la cordillera Oriental de Colombia.

\subsection{Distribución geográfica}

El Batolito de Mogotes se encuentra al occidente de la falla de Bucaramanga, tiene cerca de $45 \mathrm{~km}$ de largo y alcanza hasta $21 \mathrm{~km}$ de ancho en su zona más amplia (figura 1). La unidad tiene un rumbo preferencial NW-SE y aflora en dos Planchas geológicas del Ingeominas. La mayor parte del cuerpo está en la Plancha 136-Málaga (Vargas et al., 1984) donde ocupa un área de $390 \mathrm{~km}^{2}$, y una pequeña extensión $\left(13 \mathrm{~km}^{2}\right)$ del mismo se encuentra en el sector NW de la Plancha 152-Soatá (Vargas et al., 1987). 


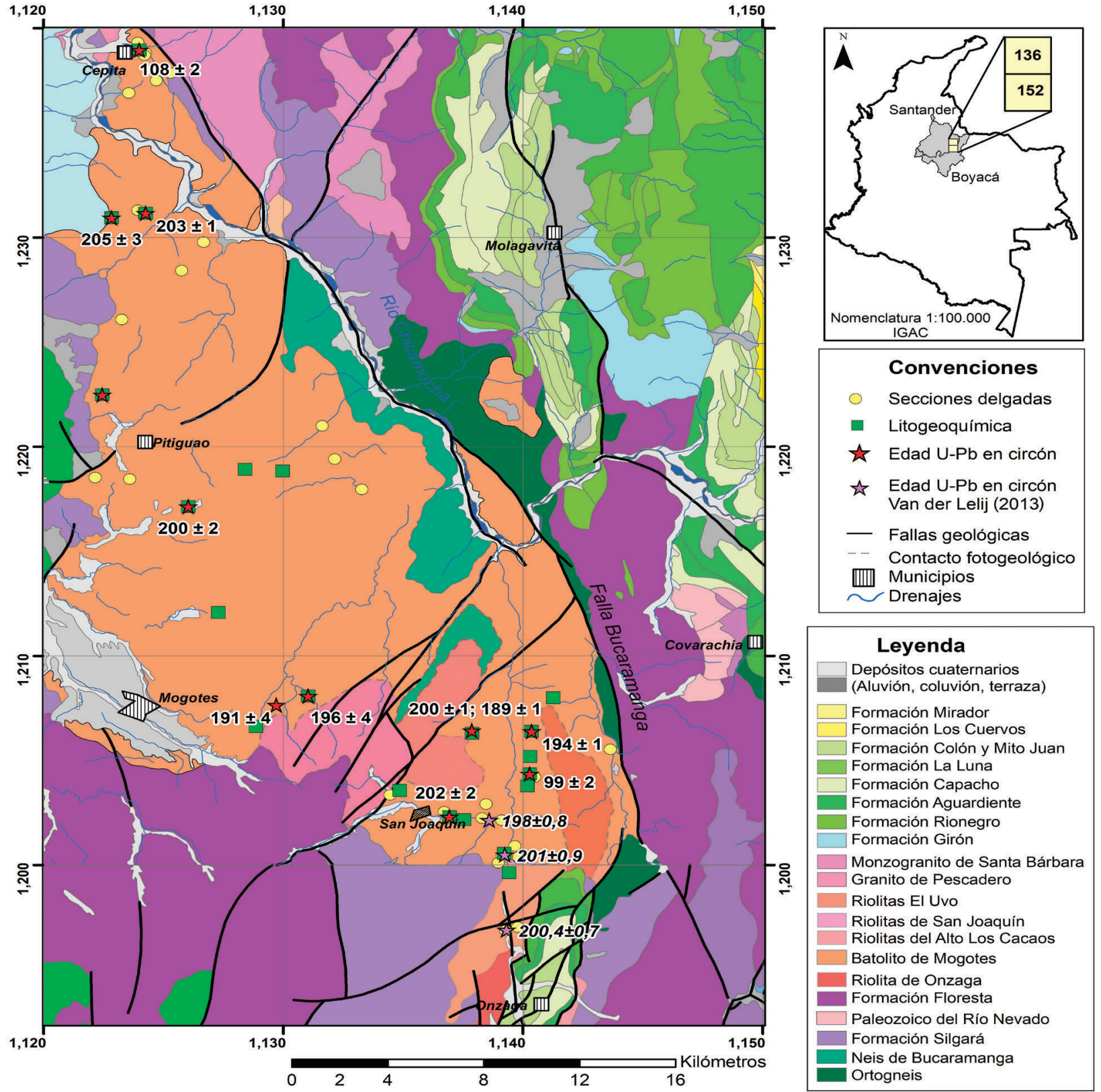

Figura 1. Ubicación del Batolito de Mogotes y estaciones con secciones delgadas, litogeoquímica y geocronología Fuente: modificado a partir de Ward et al. (1977) y Vargas et al. $(1984,1987)$

\section{Reseña histórica}

La primera referencia escrita de este cuerpo plutónico se encuentra en Goldsmith et al. (1971), aunque estos autores no describieron la unidad en términos litológicos, petrográficos o estructurales. Ward et al. (1973) utilizaron el nombre Batolito de Mogotes para designar un cuerpo compuesto por rocas cuarzomonzoníticas y granodioríticas, localizado en la parte media-sur del cuadrángulo I-1 3 del Ingeominas.
En las Memorias de la geología del cuadrángulo I-13-Málaga, Vargas et al., (1976a, 1981) usaron nuevamente la denominación Batolito de Mogotes; sin embargo, en el mapa del cuadrángulo I-13, Soatá (Vargas et al., 1976b) y de la Plancha 152-Soatá (Vargas et al., 1987), la unidad no aparece con el nombre mencionado, sino con la abreviatura y descripción "JRcm: cuarzo monzonita biotítica blanca a rosada grano medio alaskítica”, abreviatura que no consta en la memoria. Por otro lado, en el 
mapa geológico de la Plancha 136-Málaga (Vargas et al., 1976c) esta unidad JRcm (o JTRcm), junto con otras dos unidades (JRcs y JRgp) fueron agrupadas bajo la denominación de Granito de Pescadero.

En el mapa de Ward et al., (1977) aparece cartografiado hacia el extremo suroriental del Batolito de Mogotes un cuerpo de granodiorita denominado JRgd. No obstante, según lo encontrado en el presente estudio del área, no todo el cuerpo es de granodioritas, ya que en esta zona afloran dacitas, riolitas y cuarzolatitas. Van der Lelij (2013) denomina granodioritas de Onzaga y de Mogotes a los granitoides ubicados al norte de Onzaga, en lo que sería la granodiorita de Ward et al. (1977).

\section{Descripción geológica}

\subsection{Marco geológico}

El Macizo de Santander hace parte de un bloque regional triangular formado a grandes rasgos por la falla Bucaramanga, en el lado occidental, la falla de Oca-Ancón, en el lado norte, y la falla de Boconó, en el lado oriental.

Según Ward et al. (1973), las rocas del basamento del Macizo de Santander se encuentran en el Neis de Bucaramanga, el Ortoneis y la Formación Silgará, esta última denominada Esquistos de Silgará por Urueña Suárez (2014). Estas unidades están cubiertas en discordancia por rocas sedimentarias de la Formación Floresta del Devónico (Cediel, 1969).

El Neis de Bucaramanga denominado también Complejo Bucaramanga (Clavijo, 1994), consiste de neises cuarzo-feldespáticos con andalucita, sillimanita, cordierita y granate, con intercalaciones de neises hornbléndicos, anfibolitas, mármoles y migmatitas (Ward et al., 1973), metamorfizados en la facies anfibolita alta. La unidad está cubierta por la Formación Silgará, aunque las relaciones entre ambas unidades no son totalmente claras (Ward et al., 1973, Restrepo, 1995). Las rocas se interpretaban del Proterozoico (Goldsmith et al., 1971; Ward et al., 1973; Restrepo-Pace et al., 1997; García y Ríos, 1999; Cardona, 2003 y Cordani et al., 2005), aunque los resultados geocronológicos obtenidos por Van der Lelij (2013) y en este proyecto sobre el Neis de Bucaramanga indican edades de aproximadamente $465 \mathrm{Ma}$, que corresponden al Ordovícico.

La Formación Silgará de Ward et al. (1973), compuesta de rocas metamórficas pelíticas y semipelíticas, ha sido dividida por Mantilla-Figueroa et al., (2016) en tres con- juntos: el primero, denominado esquistos del Silgará, con edad máxima de depositación del protolito del Neoproterozoico Temprano y metamorfismo en facies esquisto verde situado en el Ordovícico Temprano, durante el evento orogénico Famatiniano principal (Mantilla-Figueroa et al., 2016). El segundo corresponde a los Esquistos del Chicamocha, en el que su protolito tiene una edad máxima de depositación del Cámbrico y metamorfismo en facies anfibolita situado en el Ordovícico Temprano. El tercer conjunto es el de las Filitas de San Pedro, con máxima edad de depositación de su protolito del Ordovícico Tardío; su metamorfismo aún no ha sido determinado geocronológicamente, pero se considera de finales del Ordovícico Tardío, durante el evento orogénico Famatiniano Menor (Mantilla-Figueroa et al., 2016).

El Ortoneis consiste de neises cuarzo-feldespáticos que varían en composición desde granito hasta tonalita (Ward et al., 1973), con lentes de anfibolita. En muchos lugares exhibe concordancia con estructuras del Neis de Bucaramanga y de la Formación Silgará (Ward et al., 1973). Son rocas de medio a alto grado de metamorfismo, con edades del protolito correspondientes al Ordovícico (Mantilla Figueroa et al., 2012; Van der Lelij, 2013).

Algunas edades U-Pb en circón muestran magmatismo posterior al metamorfismo, representado por metavulcanitas y plutones que intruyen el basamento metamórfico, con edades U-Pb en circón del silúrico, Devónico Inferior, Carbonífero y límite Triásico-Jurásico (Goldsmith et al., 1971; Mantilla Figueroa et al., 2012; Van der Lelij, 2013, y en este proyecto).

Durante el límite Triásico-Jurásico se desarrolló un importante magmatismo de arco de margen continental, con el emplazamiento de grandes batolitos, stocks graníticos y cuerpos riolíticos subvolcánicos localizados hacia el margen occidental del Macizo de Santander, en el basamento metamórfico (Goldsmith et al., 1971; Ward et al., 1973; Van der Lelij, 2013 y en este estudio sobre el magmatismo jurásico en Colombia).

Los plutones Triásico-Jurásicos del Macizo de Santander hacen parte del Terreno Santander, en el sentido de Etayo Serna et al., (1985). Según estos autores, el Terreno Santander tiene un basamento con metamorfismo de finales del Proterozoico (945 \pm 40 Ma), una sedimentación acumulada durante el Cámbrico (?) y metamorfoseada durante el Ordovícico-Silúrico (?), con el emplazamiento conjunto de neises graníticos y metadioritas. En este 
terreno también hay registro de una sedimentación ocurrida durante el Devónico-Pérmico y un rifting durante el Triásico-Jurásico, cuando se originaron los plutones, junto con actividad volcánica félsica a intermedia. Posteriormente, en el Jurásico, ocurrió una sedimentación intracontinental, y en el Cretácico, una sedimentación marina epicontinental.

En el sentido de Restrepo y Toussaint (1989) y Restrepo et al. (2011), los plutones Triásico-Jurásicos del Macizo de Santander hacen parte del Terreno Chibcha. De acuerdo con estos autores, dicho terreno tiene basamento continental del Precámbrico, donde el último evento tectonometamórfico es Caledoniano. Estas rocas metamórficas están cubiertas en discordancias por rocas sedimentarias del Paleozoico Superior. En el borde occidental del terreno se originó un cinturón magmático jurásico y se depositó una importante cobertura sedimentaria mesocenozoica.

Unidades sedimentarias cretácicas reposan discordantemente sobre el basamento metamórfico y los plutones. Con posterioridad a la sedimentación cretácica se dio escaso magmatismo durante el Mioceno, que de todos modos emplazó pequeños cuerpos de pórfidos con mineralización de oro (Leal-Mejía, 201 1; Mantilla Figueroa et al., 2013).

\subsection{Descripción macroscópica y microscópica}

El Batolito de Mogotes está constituido principalmente por monzogranitos y, en menor proporción, por granodioritas. En dirección del municipio de Onzaga (sector SE de la unidad), la roca es una granodiorita localmente porfirítica (Ward et al., 1973). Las granodioritas son comunes principalmente al E y NE de San Joaquín, en la vía que conduce de Las Tapias a El Morro, y en menor cantidad se presentan al SE de San Joaquín y norte de Onzaga, en la vía que de Las Tapias conduce a Onzaga, y en la parte noroeste del Batolito de Mogotes, en cercanías de Cepitá. Cuarzodioritas se hallan en la parte norte del cuerpo y como enclaves máficos pequeños de hasta $2 \mathrm{~cm}$ de diámetro, redondeados en el monzogranito en la vía Aratoca-La Palma.

En el extremo suroccidental del cuerpo, en la vía que de Mogotes conduce a San Joaquín, aflora un cuerpo de riolitas y traquitas que fue reportado por Ward et al. (1973) y cartografiado por Ward et al. (1977) como una parte del Granito de Pescadero. En la Plancha 136-Málaga
(Vargas et al., 1984), el cuerpo no aparece cartografiado. Debido a las diferencias litológicas y geocronológicas de estas rocas con los granitoides típicos del Batolito de Mogotes, en este estudio se trata el cuerpo como una unidad distinta, que se denomina Riolitas del Alto Los Cacaos. Las relaciones en campo entre ambas unidades son ambiguas, porque en algunos lugares parece que las rocas hipoabisales intruyen el batolito, y en otras, que la relación intrusiva ocurre al contrario. Este cuerpo de riolitas se describe de manera independiente del Batolito de Mogotes, en otro catálogo. Las rocas del Batolito desarrollan un relieve de montañas con aristas subangulosas y drenaje dendrítico (figura 2 A y B) y exhiben grados variables de meteorización. Donde la meteorización es intensa se encuentran saprolitos de entre 5 y 15 metros de espesor, que originan suelos arenosos de tonalidades que varían entre crema y café claro y anaranjado (figura $2 \mathrm{C}$ y D), que localmente conservan la textura granular fanerítica de grano medio (figura 2D). También hay afloramientos de roca levemente meteorizada y otros de roca fresca sin aparente intemperismo superficial (figura $2 \mathrm{E} \mathrm{y} \mathrm{F}$ ).

Se colectaron muestras de mano representativas de cada litotipo identificado en el Batolito. En algunos casos se colectaron saprolitos (de entre 2 y $3 \mathrm{~kg}$ ) para separar de estos los circones.

\subsubsection{Descripción macroscópica del cuerpo principal}

A continuación se describen las características macroscópicas de los principales litotipos del Batolito.

\subsubsection{Monzogranitos}

Los monzogranitos son de color blanco rosáceo, rosado-naranja, gris rosáceo, moteados de micas oscuras u óxidos de hierro, y comúnmente exhiben un grado alto de meteorización. Estas rocas son equigranulares a inequigranulares, con un tamaño de grano que varía de 1 a $3 \mathrm{~mm}$ (figura $2 \mathrm{E}$, figura $3 \mathrm{~A}-\mathrm{D}$ ). Se encuentran variaciones locales a rocas faneríticas de grano fino con textura sacaroidal granular. Localmente contiene enclaves desde melanocráticos hasta leucocráticos (figura 2F). Las rocas consisten de plagioclasa blanca (30 a 40\%), feldespato potásico rosado (25 a $35 \%$ ), cuarzo de color gris (20 a $30 \%$ ) y biotita (3 a $5 \%$ ), como se puede apreciar en la figura 3 . 
A
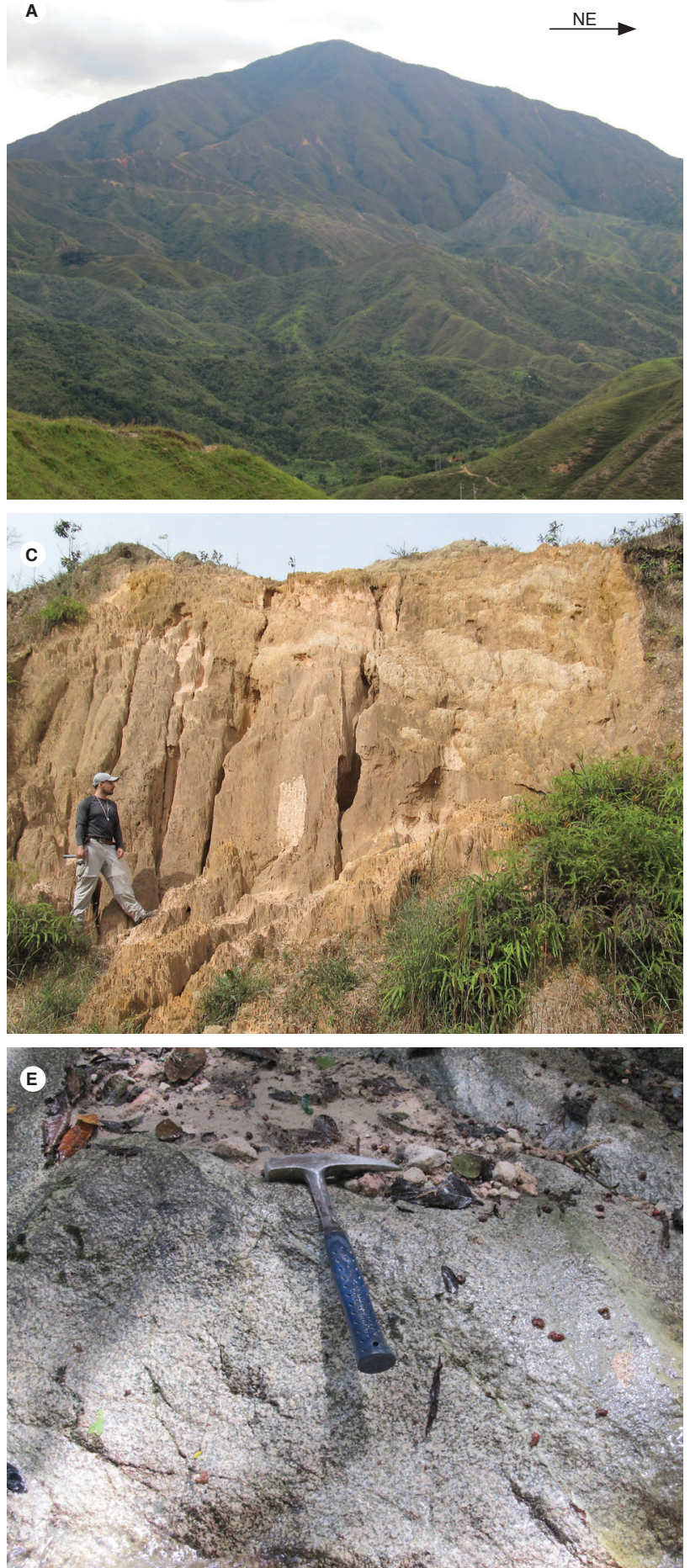
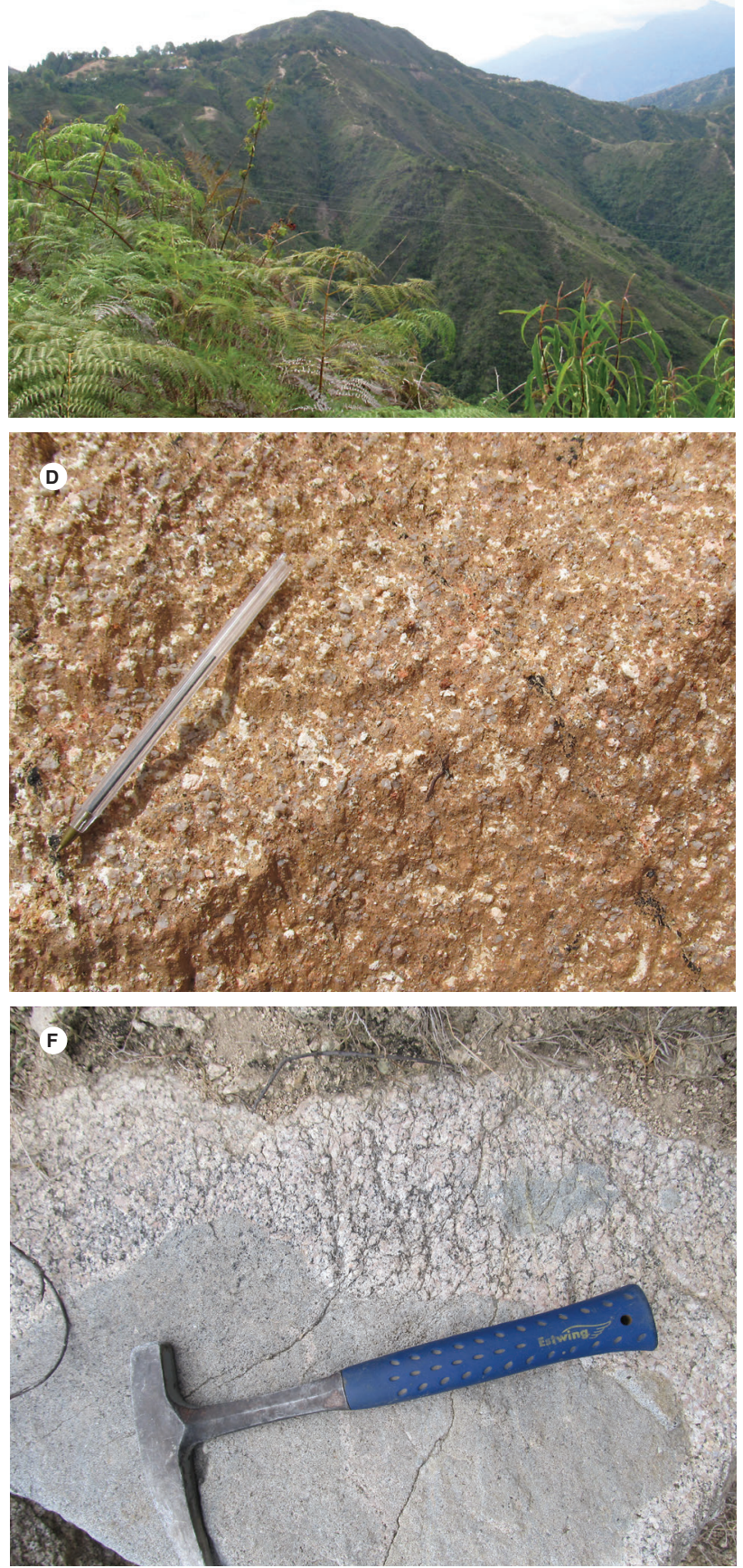

Figura 2. Imágenes de las características macroscópicas del Batolito de Mogotes

A) Geomorfología desarrollada sobre el Batolito de Mogotes de montañas con aristas subangulosas y drenaje dendrítico; imagen capturada desde la estación TCR-379. B) Geomorfología desarrollada sobre el Batolito de Mogotes de montañas con aristas subangulosas y drenaje dendrítico; imagen capturada desde la estación GR-6727. C) Saprolito espeso del Batolito de Mogotes en la estación LMC-072. D) Detalle del saprolito del Batolito de Mogotes, que conserva textura fanerítica medio granular; estación LMC-073. E) Afloramiento de monzogranito fresco en la estación GZ-6828. F) Enclave en monzogranito en la estación MIA-636 

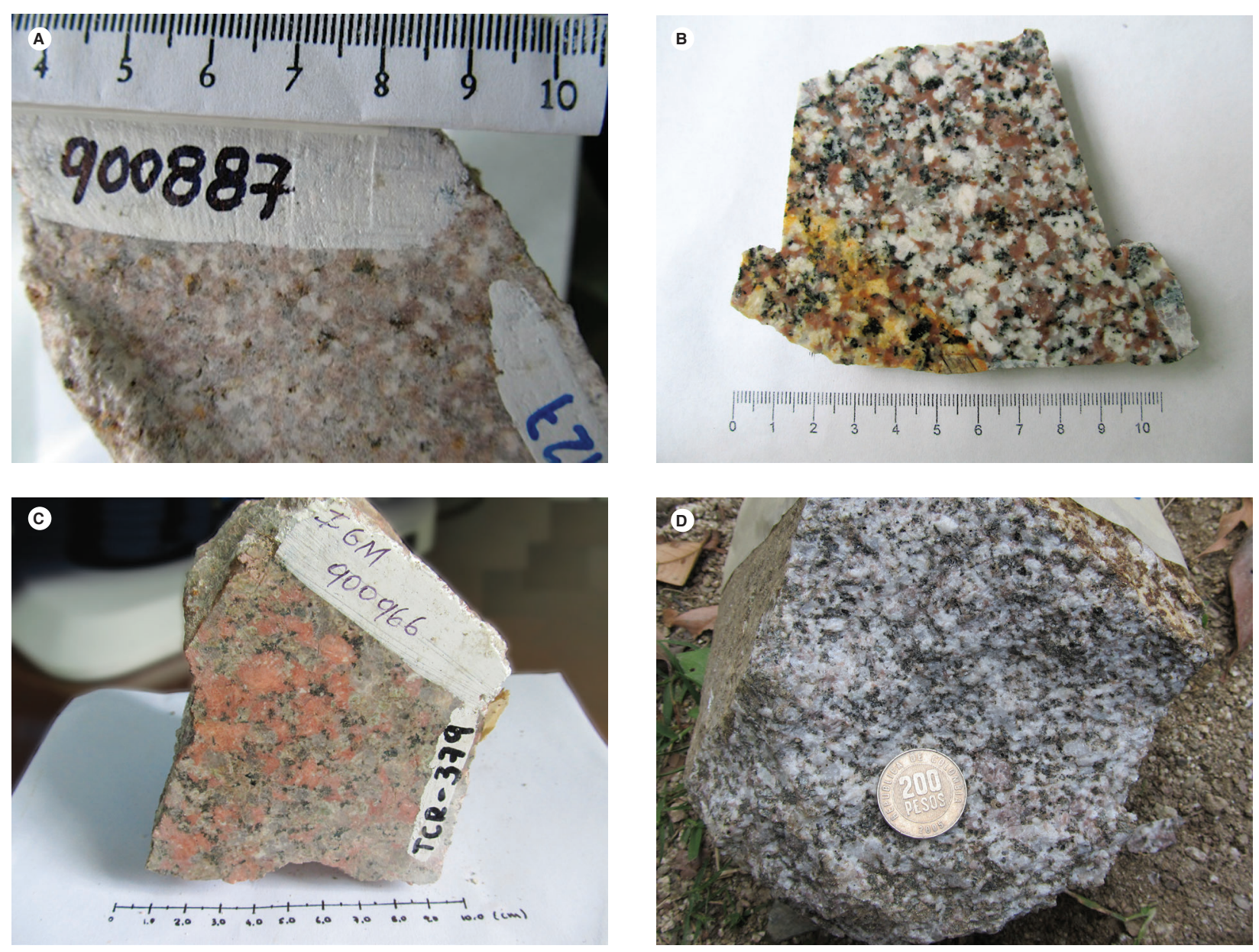

Figura 3. Fotografías de las muestras de mano de monzogranitos del Batolito de Mogotes. A) Estación GR-6727. B) Estación TCR-376. C) Estación TCR-379. D) Estación JGB-470

\subsubsection{Granodioritas y cuarzomonzodioritas}

Granodioritas y cuarzomonzodioritas se encuentran en los extremos SE (alrededores de Onzaga y occidente de San Joaquín) y N-NW del cuerpo principal (cercanías de Cepitá). Los afloramientos de esta roca se observaron frescos en los cortes de quebradas y moderadamente meteorizados en los taludes de las carreteras. Su relación con el monzogranito parece ser intrusiva, por lo que se aprecia en los alrededores del puesto de salud de Las Tapias, donde una roca melanocrática semejante a la granodiorita se presenta en venas de 5 a $10 \mathrm{~cm}$ de espesor dentro del monzogranito.
La granodiorita es gris a gris rosácea o blanco rosado, moteada de gris oscuro (figura 4A), de grano medio a grueso, de equigranular a inequigranular, compuesta por plagioclasa blanca (60\%), cuarzo gris $(10 \%)$, biotita negra y anfíbol verde oscuro (20 a $25 \%$ ) y feldespato potásico rosado a naranja pálido (5 a 10\%). En algunos puntos en la vía Las Tapias-El Morro contiene enclaves (posibles autolitos) de rocas melanocráticas porfiríticas (figura 4A). La cuarzo-monzodiorita es semejante macroscópicamente a la granodiorita, pero exhibe una ligera orientación de los minerales máficos (figura 4B), debido posiblemente a la deformación. 

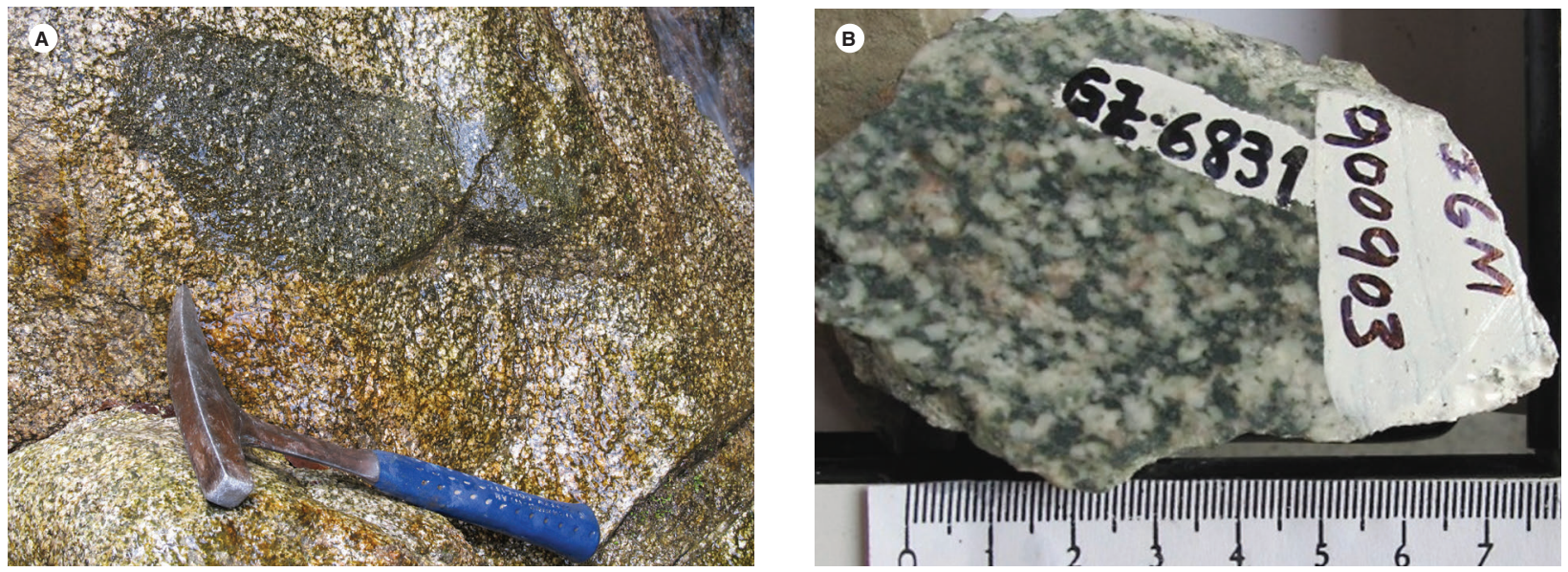

Figura 4. A) Afloramiento de granodiorita con enclaves (posible autolito) en la estación GZ-6830. B) Muestra de mano de cuarzomonzodiorita deformada, en la estación GZ-6831

\subsubsection{Descripción macroscópica de cuerpos menores}

Hay dos cuerpos menores: uno de granófido en la vía Aratoca-La Palma, y otro de sienogranito en la vía San Joaquín-Las Tapias, que exhiben características macroscópicas y edades diferentes a las típicas del Batolito de Mogotes, y por tal motivo se describen de manera independiente.

\subsubsection{Cuerpo menor de monzogranito granofídico en} borde $W$ del batolito, en la vía Aratoca-La Palma

En la parte noroccidental del batolito en la vía Aratoca-La Palma, en el sector Tempranito se encontró una roca ígnea inequigranular con cristales de tamaño de grano fino, menor o igual a $1 \mathrm{~mm}$, leucocrática de color blanco a rosado, ligeramente moteada de pardo por biotitas lixiviadas (figura 5). Consiste de feldespato potásico rosado (40\%), plagioclasa blanca (30\%), cuarzo gris (25) y biotita (5\%). Corresponde a un monzogranito fino con aspecto mesoscópico diferente del monzogranito principal. Debido a las características texturales y a la edad de 204 Ma obtenida en esta muestra se decidió tratar como un cuerpo menor independiente y diferente del Batolito de Mogotes.

\subsubsection{Cuerpo menor de sienogranito Los Trapiches}

Un cuerpo menor de sienogranito aplítico, aparentemente intrusivo en Mogotes, denominado en este trabajo sienogranito Los Trapiches, aflora en la vía San Joaquín-Las Tapias-Onzaga, en el sector de Los Trapiches. Podría corresponder a lo que Vargas et al. (1981) consi- deraron una intrusión pequeña de la Riolita de Onzaga en los alrededores de San Joaquín. Sin embargo, la roca aplítica es macroscópicamente disímil de la riolita de Onzaga, porque esta última es foliada.

El sienogranito aplítico es una roca ígnea finogranular, localmente de aspecto sacaroidal, leucocrática de color beige (figura 6), compuesta por feldespato potásico (60\%), cuarzo (25\%), plagioclasa (10 a $15 \%$ ) y biotita $(<5 \%)$.

\subsubsection{Descripción macroscópica de diques}

Diques porfídicos y aplíticos se observan en varias partes del cuerpo. Riolitas y cuarzolatitas se encontraron en la parte NE del municipio de San Joaquín y al norte Onzaga, que se denominaron Riolita de San Joaquín y Riolitas El Uvo, y se describen como unidades independientes del Batolito de Mogotes. Diques de andesita y

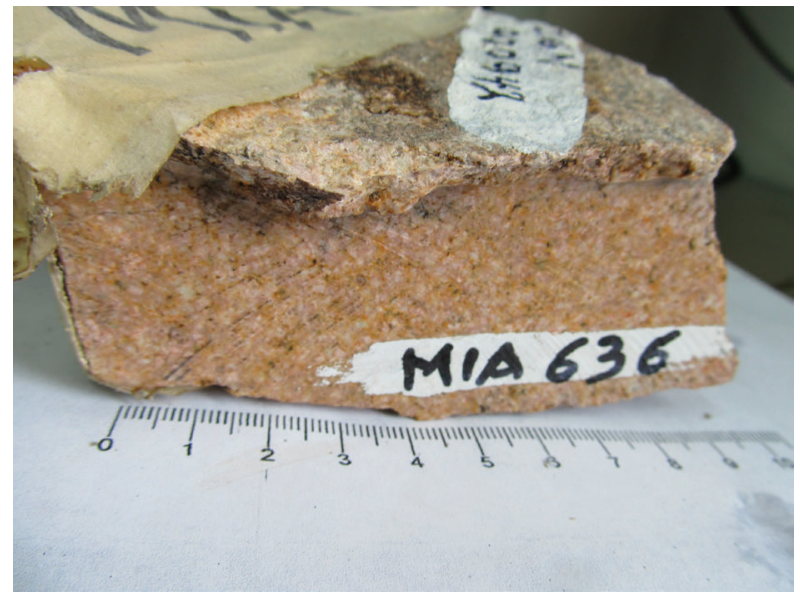

Figura 5. Muestra de mano de monzogranito finogranular encontrado en la vía Aratoca-La Palma, en la estación MIA-636 

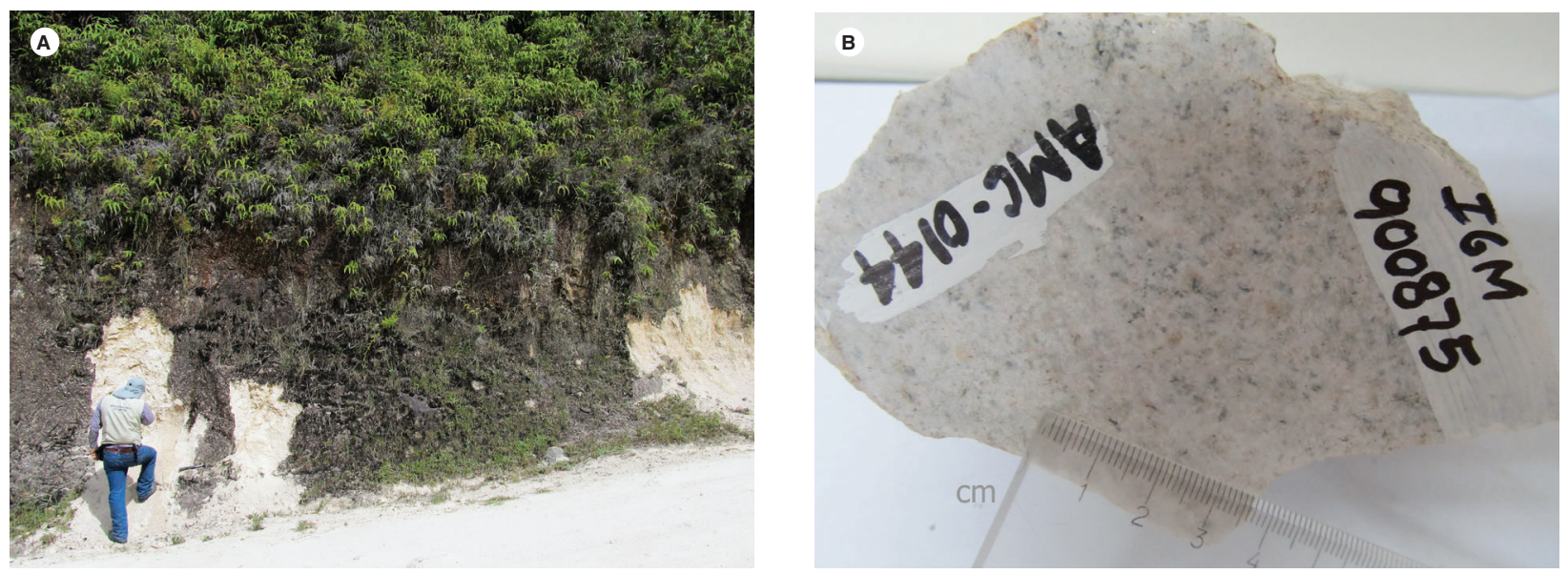

Figura 6. A) Afloramiento de sienogranito aplítico en la estación AMC-0144, en la vía San Joaquín-Las Tapias, sector Los Trapiches. B) Muestra de mano de sienogranito aplítico en la estación AMC-0144

microtonalita se encuentran en la parte sur del batolito, al norte de Onzaga y en la parte norte, en cercanías de Cepitá.

\subsubsection{Diques máficos a intermedios}

Diques de microtonalita alterada que varían en espesor de 0,6 a 1,6 m se encuentran sobre la vía Cepitá-San Miguel, en la parte norte del batolito (figura 7A). Son finogranulares masivos, de color verde oscuro por la presencia de minerales de alteración propilítica, como epidota y clorita. Otro dique de una clasificación similar, pero no tan alterado, se encuentra al norte de Onzaga.

Un dique máfico de aproximadamente $12 \mathrm{~m}$ de ancho saprolitizado y cizallado se halla cortando el Batolito de Mogotes en la vía Aratoca-desvío La Palma, en el sector Tempranito (estación MIA-636).

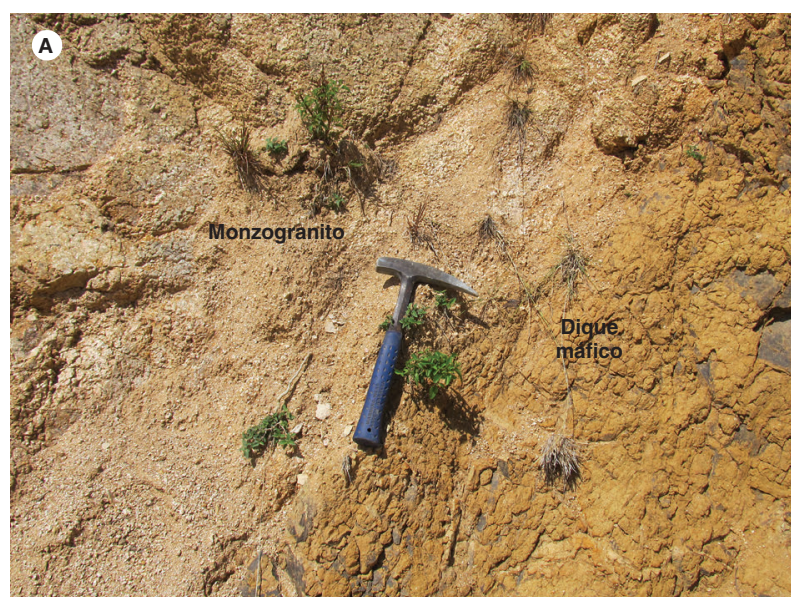

Diques de andesita se hallan en la parte sur del cuerpo, al norte de Onzaga, y otros de andesita hornbléndica, en la parte norte del batolito, al este de Cepitá.

Un dique de granodiorita metamorfizada se encontró en el sector de El Morro, al NE de San Joaquín (estación GZ-6833), donde intruye los esquistos de la Formación Silgará.

\subsubsection{Diques félsicos}

En diferentes partes del batolito se encuentran diques aplíticos de composición sienogranítica a monzogranítica y porfídicos, en su mayoría de composición riolítica.

Diques aplíticos y porfídicos de color blanco se aprecian en la parte SW del batolito, en la vía San Joaquín-San Martín (La Aurora). Los diques aplíticos se presentan de hasta $10 \mathrm{~m}$ de espesor y están cortados a veces por venas

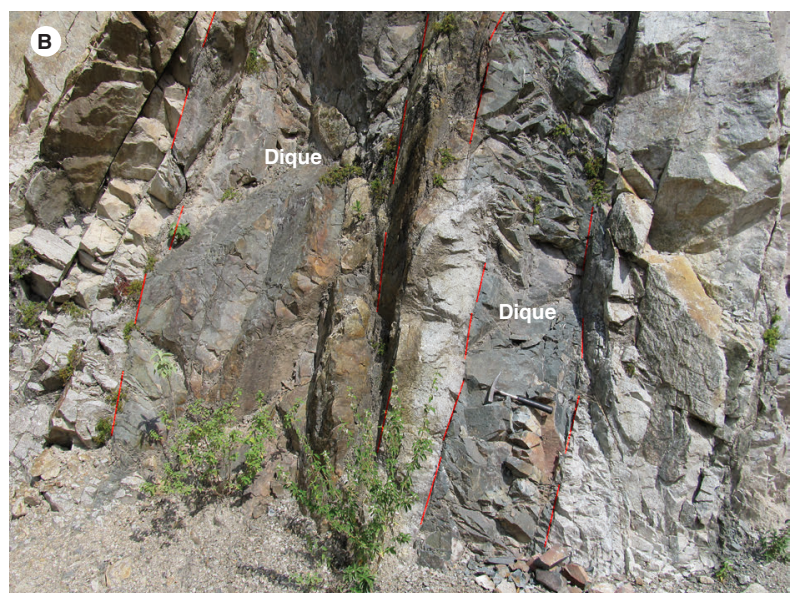

Figura 7. A) Saprolito de dique máfico cortando el monzogranito en la estación MIA-636. B) Diques de microtonalita en monzogranito, en la vía Cepitá-San Miguel, estación AMC-0136 
de cuarzo lechoso. Corresponden a granitoides aplíticos faneríticos de grano muy fino a fino, con textura sacaroidal, y están compuestos por cuarzo (20 a 30\%) y feldespatos blancos (60 a 70\%) con biotita (1\%). Se encontró un dique de monzogranito granatífero (estación GR-6727). En la vía Las Tapias-El Morro (estación GZ-6829) hay diques de sienogranito.

En la parte norte del batolito, sobre la vía Aratoca-La Palma, se hallan diques félsicos finogranulares aplíticos (estación TCR-376A) y porfídicos (estaciones MIA-636 y TCR-376). Los aplíticos son de $15 \mathrm{~cm}$ de espesor en promedio, y están compuestos por cuarzo (60\%), plagioclasa (28\%), feldespato potásico (10\%) y biotita (2\%). En esta vía existen en forma de diques rocas félsicas inequigranulares con fenocristales de feldespato y cuarzo embebidos en una matriz afanítica felsítica.

\subsubsection{Características microscópicas del cuerpo principal}

Las secciones delgadas y delgadas pulidas fueron confeccionadas en el Laboratorio de Petrografía del Servicio Geológico Colombiano, en Bogotá. Para la caracterización petrográfica de las rocas plutónicas en el cuerpo de Mogotes se analizaron catorce secciones delgadas de rocas elaboradas durante la ejecución del proyecto "Magmatismo jurásico en Colombia, Macizo de Santander" (véase la ubicación en la figura 1), se reanalizaron trece secciones delgadas y se compilaron trece descripciones de proyectos anteriores no determinados, del Ingeominas. La composición modal, que se resume en la tabla 1 y se visualiza en la figura 9, se determinó a partir del conteo de puntos. La abreviatura de minerales es la de Whitney y Evans (2010).
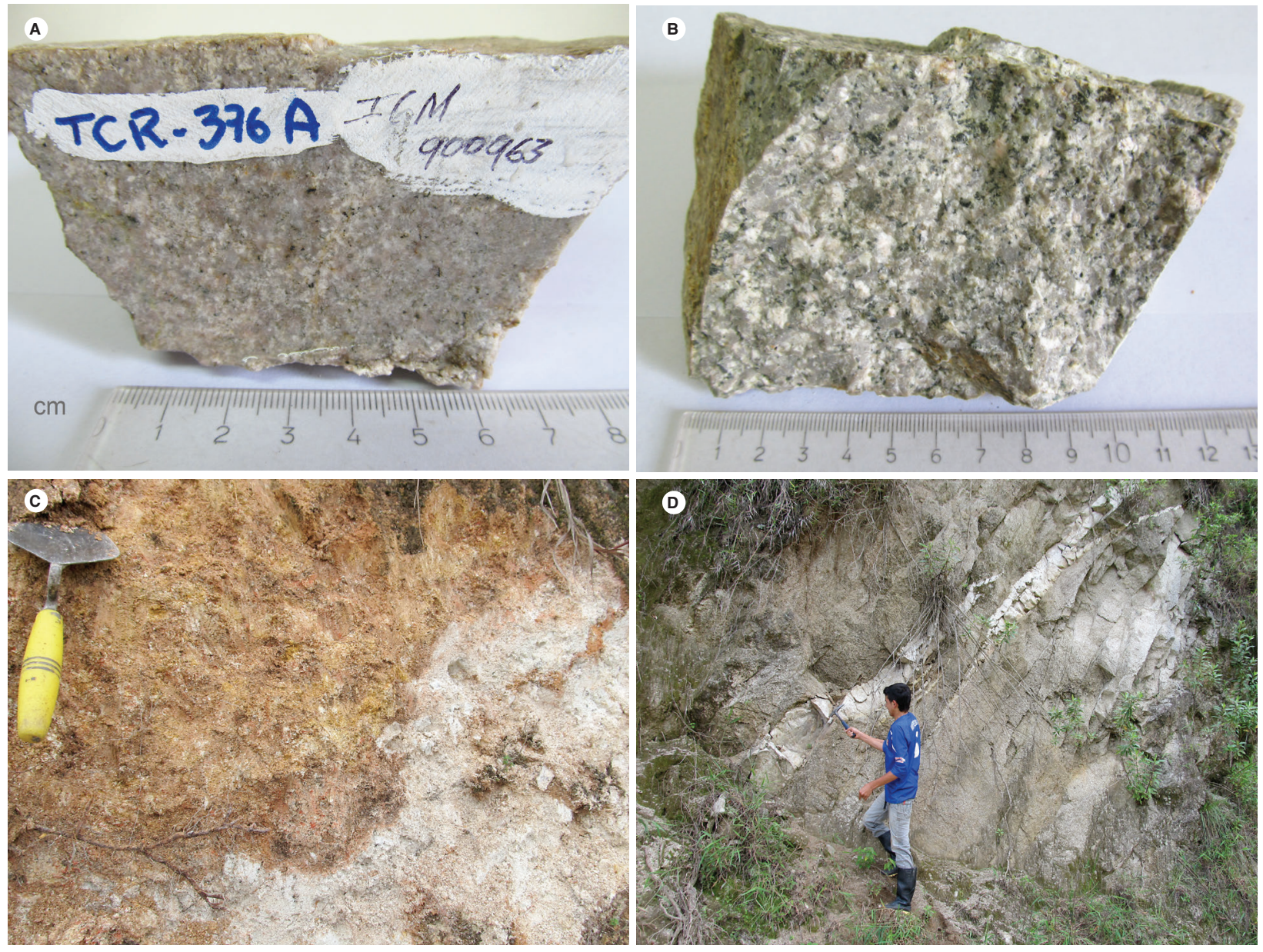

Figura 8. Fotografías de diques félsicos que cortan el Batolito de Mogotes

A) Muestra de mano de dique de sienogranito, en la estación TCR-736. B) Muestra de mano de dique de fenocuarzolatita, en estación TCR-736. C) Dique félsico de cuarzolatita en contacto con monzogranito, en la estación LMC-071. D) Diques félsicos de sienogranito en la estación GZ-6829 
Tabla 1. Composición modal de las rocas plutónicas principales en el Batolito de Mogotes

\begin{tabular}{|c|c|c|c|c|c|c|c|c|c|c|c|c|c|c|c|}
\hline $\operatorname{lgm}$ & w & $\mathbf{N}$ & Qtz & PI & Fsp & $\mathrm{Hbl}$ & Bt & Ms & Op & Ap & Zrn & Ttn & Aln & Otros & Clasificación \\
\hline 37303 & 1124710 & 1237510 & 11 & 83 & & & & & & 0,5 & 0,5 & & & 5 & Cuarzodiorita \\
\hline 37304 & 1125300 & 1237860 & 12 & 75 & 2 & & 6 & & 1 & 1 & 1 & 1 & & 1 & Cuarzodiorita \\
\hline 10909 & 1139824 & 1200391 & 14,5 & 52 & 20 & 0,5 & 10 & & 1 & 0,5 & 0,5 & 1 & & & Cuarzomonzodiorita \\
\hline 900903 & 1140363 & 1206394 & 14,7 & 54,5 & 11,9 & & 18,6 & & $\operatorname{Tr}$ & & $\operatorname{Tr}$ & 0,3 & $\operatorname{Tr}$ & & Metacuarzomonzodiorita \\
\hline 37302 & 1124700 & 1238060 & 18 & 33 & 39 & & 6 & & 1,5 & 1 & 1,5 & & & & Cuarzomonzonita \\
\hline 73670 & 1138480 & 1202240 & 15 & 30 & 35 & & 10 & & 3 & $\mathrm{x}$ & & 2 & & & Cuarzomonzonita \\
\hline 900902 & 1140297 & 1205191 & 21,1 & 46,3 & 16,5 & 6,3 & 8,8 & & 0,5 & $\operatorname{Tr}$ & $\operatorname{Tr}$ & 0,5 & & & Granodiorita \\
\hline 10906 & 1139110 & 1202152 & 26 & 37,5 & 17 & 5 & 12 & & 1 & & 0,5 & 1 & & & Granodiorita \\
\hline 13263 & 1131624 & 1220996 & 21 & 46 & 11 & & 13 & & 2,5 & 0,5 & 1,5 & 4,5 & & & Granodiorita \\
\hline 14356 & 1140492 & 1204203 & 24,5 & 39,4 & 21,6 & 13,4 & 0,7 & & $\mathrm{Tr}$ & & $\mathrm{Tr}$ & 0,3 & 0,1 & & Granodiorita \\
\hline 37307 & 1123940 & 1239320 & 45 & 37 & 11 & & 2 & & 1 & & 1 & & & 3 & Granodiorita \\
\hline 37690 & 1138300 & 1202250 & 24,9 & 45,7 & 18,9 & & 8 & & 0,5 & 1,1 & 0,2 & 0,5 & & 0,2 & Granodiorita \\
\hline 73671 & 1139660 & 1200920 & 28 & 47 & 16 & 1 & 6 & & 1 & $\operatorname{Tr}$ & & 1 & & & Granodiorita \\
\hline 73672 & 1141550 & 1200400 & 16 & 42 & 20 & 9 & 13 & & $\mathrm{Tr}$ & $\mathrm{Tr}$ & $\mathrm{Tr}$ & $\mathrm{Tr}$ & & & Granodiorita \\
\hline 37300 & 1124020 & 1238900 & 27 & 40 & 8 & & & & 1 & 1 & & & & 23 & Granodiorita \\
\hline 73676 & 1139780 & 1197040 & 42 & 40 & 14 & & & & & & & $x$ & & & Metagranodiorita \\
\hline 14346 & 1139460 & 1223192 & 30 & 43 & 15 & & 12 & & $\mathrm{Tr}$ & $\mathrm{Tr}$ & $\mathrm{Tr}$ & $x$ & & & Metagranodiorita \\
\hline 900869 & 1123996 & 1238967 & 34 & 24,5 & 36 & & 4,5 & & 1 & $\mathrm{Tr}$ & $\mathrm{Tr}$ & & & & Monzogranito \\
\hline 900879 & 1139278 & 1196886 & 27 & 37 & 24 & 1 & 10 & & $\operatorname{Tr}$ & $\operatorname{Tr}$ & $\operatorname{Tr}$ & 0,5 & 0,5 & & Monzogranito \\
\hline 900887 & 1129973 & 1218837 & 40,2 & 29,9 & 26,1 & 0,5 & 2,7 & & 0,6 & $\operatorname{Tr}$ & $\operatorname{Tr}$ & $\operatorname{Tr}$ & & & Monzogranito \\
\hline 900900 & 1140183 & 1203787 & 18,5 & 30,9 & 31,5 & 18,5 & & & 0,6 & & & & & & Monzogranito \\
\hline 900917 & 1139227 & 1200562 & 27,6 & 35,4 & 31,0 & & 6,0 & & $\mathrm{Tr}$ & $\operatorname{Tr}$ & $\operatorname{Tr}$ & & & & Monzogranito \\
\hline 900927 & 1131045 & 1208090 & 35 & 25 & 38 & & 2 & & $\mathrm{Tr}$ & $\mathrm{Tr}$ & $\mathrm{Tr}$ & & & & Monzogranito \\
\hline 900943 & 1128418 & 1218926 & 25,2 & 28,7 & 33,2 & & 12,5 & & 0,4 & $\mathrm{Tr}$ & $\mathrm{Tr}$ & & & & Monzogranito \\
\hline 900944 & 1126040 & 1217144 & 25,8 & 32,6 & 39,6 & & 1 & $x$ & 0,5 & 0,5 & $\mathrm{Tr}$ & & & & Monzogranito \\
\hline 900962 & 1124265 & 1231161 & 25,5 & 40 & 24 & & 8 & & 1,7 & 0,5 & 0,3 & & & & Monzogranito \\
\hline 900965 & 1127293 & 1212077 & 37 & 25 & 33 & & 3,5 & & 1 & 0,3 & 0,3 & & & & Monzogranito \\
\hline 900966 & 1128868 & 1206624 & 18,5 & 27,5 & 41 & & 11,5 & & 1,3 & & 0,2 & & & & Monzogranito \\
\hline 10905 & 1138462 & 1202918 & 28 & 23 & 38 & & 7 & & 2 & $\mathrm{Tr}$ & 1 & $\mathrm{Tr}$ & 1 & & Monzogranito \\
\hline 10915 & 1123599 & 1218456 & 30 & 28 & 41,5 & & 0,5 & $x$ & $\mathrm{Tr}$ & & $\operatorname{Tr}$ & & & & Monzogranito \\
\hline 10916 & 1122157 & 1218528 & 22,8 & 31,1 & 43,4 & & 1,7 & & 1 & & $\mathrm{Tr}$ & & & & Monzogranito \\
\hline 13265 & 1123559 & 1236907 & 25 & 38 & 25 & & 6,5 & & 2,5 & 0,5 & 0,2 & 2,3 & & & Monzogranito \\
\hline 13275 & 1123936 & 1231305 & 36,5 & 24,5 & 35 & & 3 & & 0,5 & 0,5 & & & & & Monzogranito \\
\hline 14355 & 1143647 & 1205531 & 26,2 & 28,8 & 32,5 & 1,2 & 10,9 & & 0,2 & $\mathrm{Tr}$ & $\mathrm{Tr}$ & 0,2 & $\mathrm{Tr}$ & & Monzogranito \\
\hline 37291 & 1123270 & 1226081 & 22 & 42 & 27 & & 6 & & & 1 & & 1 & & 1 & Monzogranito \\
\hline 37301 & 1124250 & 1238840 & 26 & 34 & 32 & & 3 & & 1 & 1 & 1 & 1 & & 1 & Monzogranito \\
\hline 37691 & 1133280 & 1217960 & 17 & 34,5 & 30.5 & & 6.5 & 0.5 & 1 & 2 & $\mathrm{Tr}$ & & & 5 & Monzogranito \\
\hline 900874 & 1139427 & 1199642 & 35 & 28 & 34 & & 3 & $x$ & & & $\mathrm{Tr}$ & & & & Monzogranito deformado \\
\hline 13245 & 1125762 & 1228417 & 38 & 20 & 40 & & 1 & $x$ & 1 & $\mathrm{Tr}$ & $\operatorname{Tr}$ & & $\mathrm{Tr}$ & & Sienogranito \\
\hline 37712 & 1132150 & 1219410 & 40 & 20 & 39 & & 1 & & & $\mathrm{x}$ & $\mathrm{x}$ & $x$ & $\operatorname{Tr}$ & & Sienogranito \\
\hline
\end{tabular}




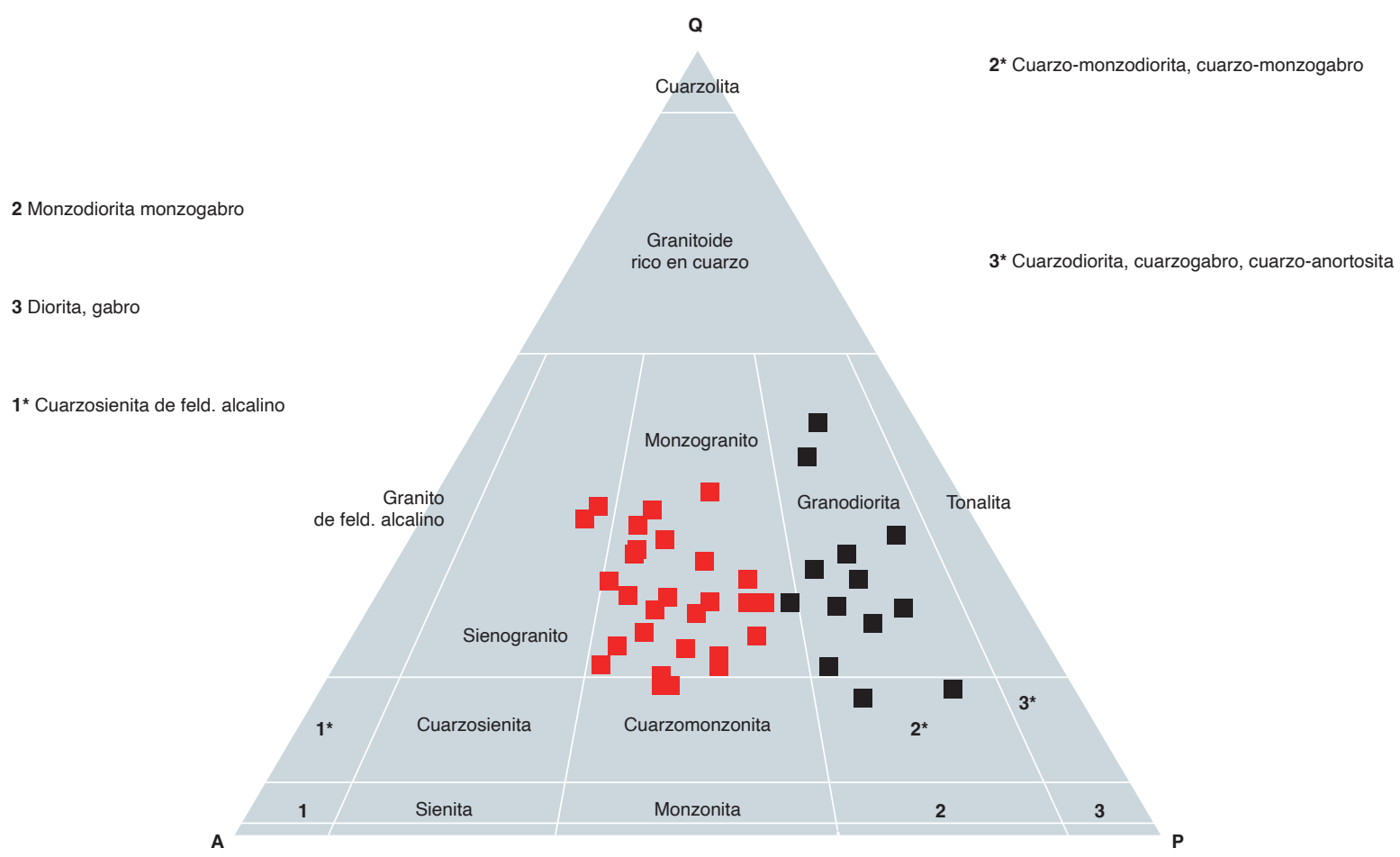

Figura 9. Triángulo QAP de Streckeisen (1974) que muestra la composición modal de las rocas plutónicas del Batolito de Mogotes En cuadrados rojos, monzogranitos, sienogranitos y cuarzomonzonitas; en cuadrados negros, granodioritas, cuarzomonzodioritas y cuarzodioritas

El Batolito de Mogotes está compuesto principalmente por monzogranitos (52,5\%), seguidos de granodioritas $(27,5 \%)$, y en muy baja proporción, por sienogranitos (5\%), cuarzomonzonitas (5\%), cuarzomonzodioritas (5\%) y cuarzodioritas (5\%). A nivel microscópico se observa que muestras del NE de San Joaquín, recogidas en el sector de El Morro y al norte de Onzaga, exhiben deformación, y en su denominación se introdujo el prefijo “meta-".

\subsubsection{Monzogranitos, sienogranitos \\ y cuarzomonzonitas}

Los monzogranitos exhiben principalmente textura hipidiomórfica (figura 10A) inequigranular (IGM 900962, 900917, 900943, 900966, 900900, 10905, 10915, 10916, 13265, 13275, 14355, 37291, 37301 y 37691). En algunas muestras (IGM 900869, 900887, 900944 y 900965) se aprecian además las texturas alotriomórfica inequigranular, la micrográfica y mirmequítica (figura 10 B y C), y en una muestra (IGM900927) se observa que la textura mirmequítica y micrográfica es posterior y se superpone a la alotriomórfica inequigranular (figura 10C). De manera subordinada aparece la textura poiquilítica (figura 10D) con oikocristales de feldespato potásico y cuarzo encerrando cristales menores de plagioclasa, feldespato potásico y biotita.

Al norte de Onzaga, el monzogranito se encuentra con deformación dinámica en la que los cuarzos se hallan en agregados de subgranos, y las biotitas, estiradas y dobladas. Consisten de cuarzo (17 a $40 \%$, si bien la población dominante está entre 22 y $28 \%$ ), plagioclasa (23 a $42 \%$, con la población dominante entre 23 y $31 \%$ ), feldespato potásico (24 a 43,4\%, con la población dominante entre 30 y $41 \%)$, biotita $(0,5$ a $12,5 \%$, con la población principal entre 3 y $7 \%$ ), y en esporádicas muestras se encuentra hornblenda, alrededor de $1 \%$, aunque en una muestra (IGM900900) se encontró en un 18,5\%. Como minerales accesorios se encuentran apatito, circón, opacos, titanita y allanita.

Se encontraron dos secciones delgadas que pueden clasificarse como sienogranitos en límite con monzogranito. De una de las secciones delgadas (IGM37712) se retomó la descripción original realizada en el año de 1992 (formato que hace parte del acervo del Servicio Geoló- 

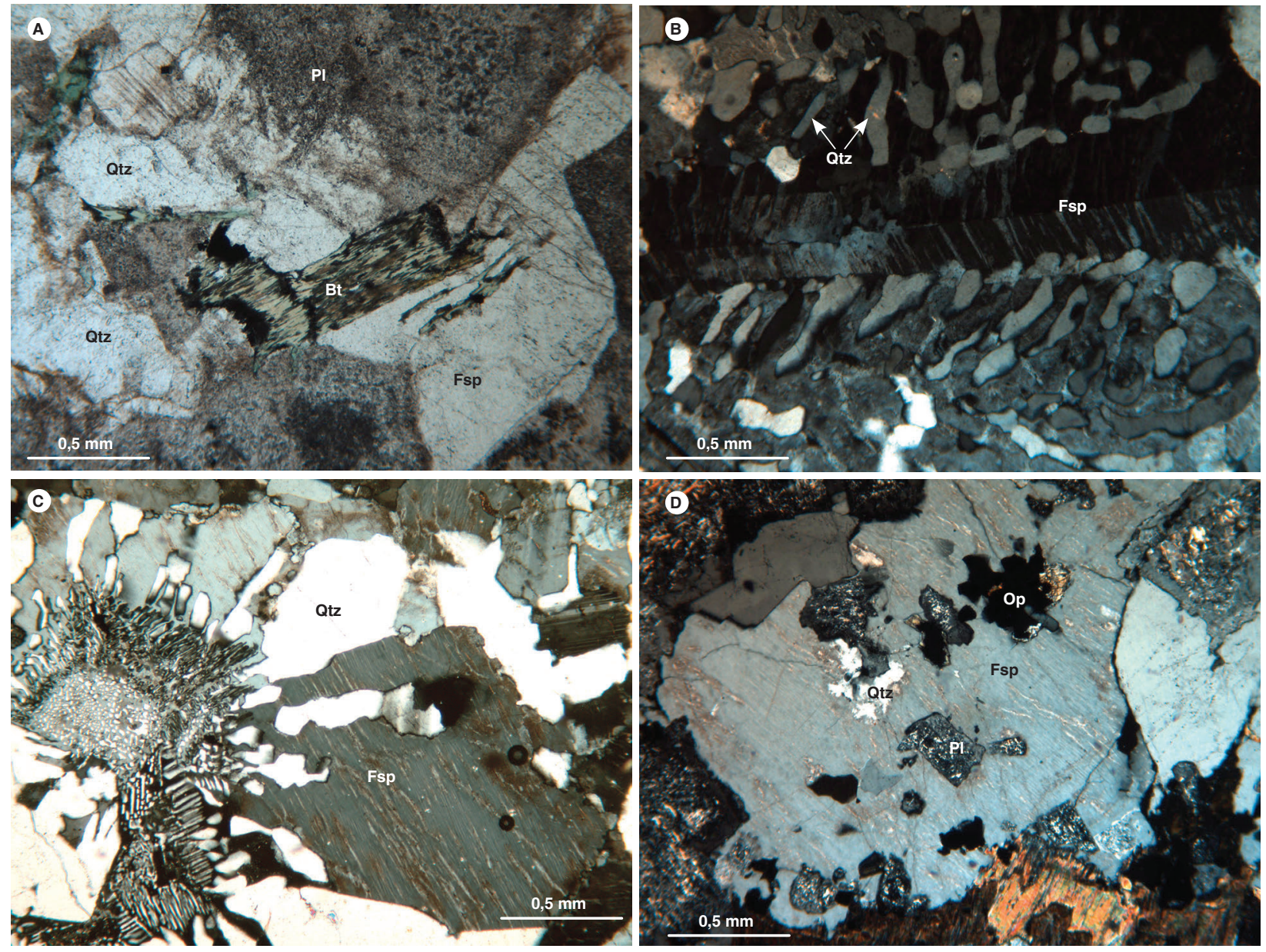

Figura 10. Microfotografías en las que se muestran las texturas de los monzogranitos del Batolito de Mogotes y las características del feldespato potásico en estas rocas. A) GM900962. Textura general, hipidiomórfica inequigranular. Nícoles paralelos. B) IGM900944. Textura micrográfica dada por inclusiones alargadas de cuarzo (Qtz) que contrastan con el feldespato potásico (Fsp) alterado a caolín. Nícoles cruzados. C) IGM900927. Crecimiento mirmequítico sobre feldespato potásico con desmezclas pertíticas. Nícoles cruzados. D) IGM14355. Textura poiquilítica con inclusiones de plagioclasa $(\mathrm{Pl})$, cuarzo $(\mathrm{Qtz})$ y opacos $(\mathrm{Op})$ en feldespato potásico. Nícoles cruzados

gico Colombiano), y la otra (IGM1 3245) se reinterpretó en este estudio. Ambas se describen junto con los monzogranitos, suponiendo que son una variación del monzogranito principal del batolito, pero en realidad no se tiene información sobre su forma de existencia, ni de sus relaciones con las otras rocas. También hay dos muestras (IGM 37302 y 73670) clasificables en el campo de las cuarzomonzonitas, en límite con el monzogranito, que se incluyen en la descripción del monzogranito.

El cuarzo aparece en cristales anhedrales, con bordes irregulares, incoloros, limpios, algunos con inclusiones de polvo a manera de líneas o caminillos, con microfracturas irregulares internas. La extinción es ondulatoria, de moderada a fuerte. En el monzogranito deformado muestra formación de subgranos. Pueden tener inclusiones de plagioclasa, feldespato potásico, biotita y apatito. En algunas muestras forman mosaicos de granos. En varias muestras aparece en los bordes de cristales de feldespato potásico, como producto de reacción entre feldespatos potásicos o entre feldespato potásico y plagioclasa. También puede encontrarse en finas venillas que atraviesan los cristales de feldespato potásico. El tamaño de cristales varía entre 0,2 y $3 \mathrm{~mm}$, si bien predomina el rango de 0,5 a $2 \mathrm{~mm}$.

La plagioclasa se presenta en cristales subhedrales a euhedrales, con bordes rectos. Su grado de alteración es variable, por lo que se los halla desde incoloros, cuando están frescos, hasta parduzcos, por fuerte sericitación y saussuritización. Presentan maclas de albita, Carlsbad y combinadas albita-Carlsbad. Esporádicamente se aprecia macla de la periclina; también son comunes los cristales zonados con zonación oscilatoria (figura 11A), y en ocasiones los núcleos muestran mayor alteración que los 
bordes. La composición según el método de Michel-Lévy varía entre oligoclasa - $\mathrm{An}_{28} \mathrm{y}$ andesina - $\mathrm{An}_{38}$. Ocasionalmente se presenta como inclusiones dentro del feldespato potásico y del cuarzo. Los tamaños varían entre 0,5 y $5 \mathrm{~mm}$, aunque predominan el rango entre 1 y 2,5 $\mathrm{mm}$.

El feldespato potásico se presenta en cristales anhedrales a subhedrales de contornos irregulares, y corresponde a ortosa y, en menor cantidad, a ortosa, pasando a microclina. Los cristales son incoloros cuando están frescos, aunque normalmente exhiben una superficie parduzca debido a la caolinización. Es común que presenten micropertitas, principalmente en cordones (figura 11B), y en menor cantidad en venas y parches. Esporádicamente pueden mostrar macla de Carlsbad (figura 11B) y maclas mal desarrolladas de microclina. Pueden desarrollar texturas poiquilíticas con inclusiones de cuarzo, plagioclasa, biotita y apatito. Ocasionalmente generan bordes de reacción en los contornos de los cristales de mayor tamaño y con las plagioclasas que tienen incluidas. Puede aparecer como inclusiones dentro del cuarzo. En algunas muestras puede desarrollar texturas gráficas con cuarzo. En el caso de la muestra IGM900927, el crecimiento gráfico de feldespato potásico-cuarzo se superpone a los cristales de feldespato potásico con textura pertítica (figura 10C). Los tamaños varían de 0,3 a $4 \mathrm{~mm}$, aunque predomina el rango entre 0,5 y 2,5 $\mathrm{mm}$.

La biotita aparece en láminas subhedrales a euhedrales (figura 12A), algunas de forma hexagonal. De color pardo, con pleocroísmo X: pardo medio, Y-Z: pardo oscuro, con extinción paralela al clivaje y en ojo de pá- jaro. Se puede encontrar inalterada, pero por lo general está alterada a clorita con epidota-clinozoisita, magnetita y en ocasiones con titanita. Comúnmente tiene inclusiones de apatito, circón y opacos, y localmente, de cuarzo y plagioclasa. Algunos cristales en cortes transversales muestran inclusiones de rutilo como finas agujas incoloras que se disponen a $60^{\circ}$, semejando una textura sagenítica. Los tamaños varían de 0,1 a $2 \mathrm{~mm}$, si bien el rango predominante se encuentra entre 0,5 y $1 \mathrm{~mm}$.

La hornblenda se observa en pocas muestras de monzogranitos (IGM 900900, 900887, 14355). Se halla en cristales subhedrales a euhedrales (figura 12B), en cortes basales y longitudinales, pleocroicos de color pardo amarillento a verde oliva. Puede tener inclusiones de opacos, epidota, cuarzo y circón. El tamaño predominante está entre 0,5 y 1,5 mm.

Los opacos se presentan en cristales anhedrales y subhedrales-euhedrales, muy finos a finos. Los muy finos (0,05 a 0,1 mm) son anhedrales y aparecen diseminados en la roca, principalmente en los clivajes de biotita alterada, y deben ser opacos secundarios. Los finos muestran un tamaño predominante entre 0,2 y $0,5 \mathrm{~mm}$, si bien pueden llegar hasta $1 \mathrm{~mm}$, y parecen corresponder a opacos primarios (figura 13A). Hay cristales anhedrales que a la luz reflejada son de color gris con tinte rosado y reflectancia baja; localmente, en bordes presentan hematita de color gris a blanco. Algunos tienen fracturas rellenas de clorita. Los subhedrales-euhedrales exhiben contornos cuadrados resultantes de un hábito cúbico, y pueden corresponder a pirita.
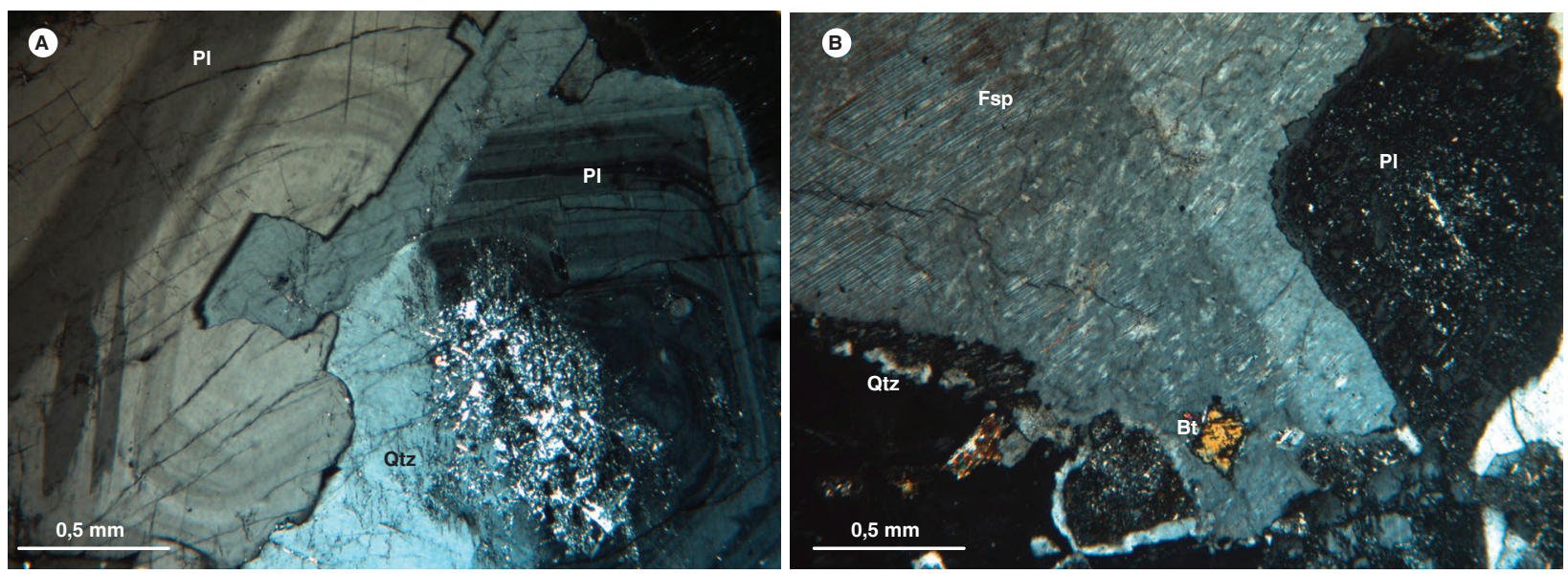

Figura 11. Microfotografías en las que se observan texturas y minerales en los monzogranitos del cuerpo Batolito de Mogotes. A) IGM10905. Cristales de plagioclasa (PI) con zonación oscilatoria. Nícoles cruzados. B) IGM900943. Texturas de exsolución-pertitas y maclas tipo Carlsbad en feldespato potásico (Fsp), plagioclasa (PI) alterada a sericita, láminas finas de biotita (Bt). Nícoles cruzados 

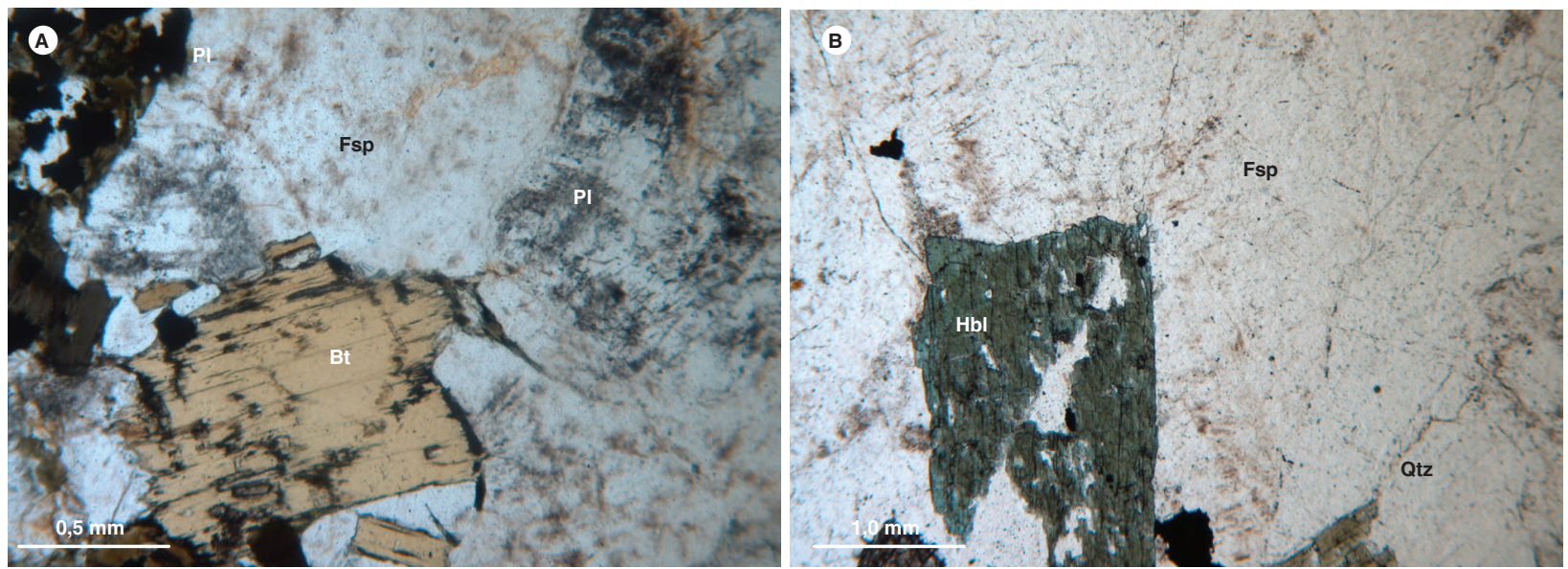

Figura 12. Microfotografías que muestran las características de la biotita y la hornblenda en los monzogranitos del Batolito de Mogotes. A) IGM900917. Cristales euhedrales de biotita (BT), plagioclasa (PL) alterada a saussurita y feldespato potásico (Fsp). Nícoles paralelos. B) IGM900900. Textura hipidiomórfica inequigranular. Compuesta por plagioclasa (PI), cuarzo (Qtz), feldespato potásico (Fsp) y hornblenda (Hbl). Nícoles paralelos

El apatito se presenta en cristales euhedrales y subhedrales prismáticos, en cortes basales hexagonales (figura 13B) y longitudinales, incoloros. Se encuentran principalmente asociados a biotita como inclusiones o en sus bordes, pero también pueden estar incluidos en plagioclasa y feldespato, y diseminados en la roca. En general, son menores de $0,3 \mathrm{~mm}$ en su dimensión mayor.

El circón aparece en cristales euhedrales prismáticos e incoloros (figura 13A). Se presenta como inclusiones, principalmente en biotita, y también puede estar incluido en feldespato potásico, plagioclasa, cuarzo y anfíbol. Es común hallarlo asociado a opacos. El tamaño en general es menor de $1 \mathrm{~mm}$.
La titanita es un mineral accesorio que se aprecia solo en algunas muestras. Se presenta en cristales euhedrales (figura 13A) de hábito rómbico, color amarillo oscurecido, levemente pleocroico a marrón oscuro sin pleocroísmo. Está asociada con los opacos, la biotita cloritizada, los cristales que parecen haber sido anfíbol y como inclusión en los feldespatos. Muestra extinción paralela. Generalmente se observa fracturada, y su tamaño varía entre 0,5 y $1 \mathrm{~mm}$.

La allanita se encuentra en cristales subhedrales y euhedrales. Su forma es prismática, su color, marrón intenso (figura 14), levemente pleocroico, tiene relieve muy alto y desarrollo de marcadas fracturas irregulares.
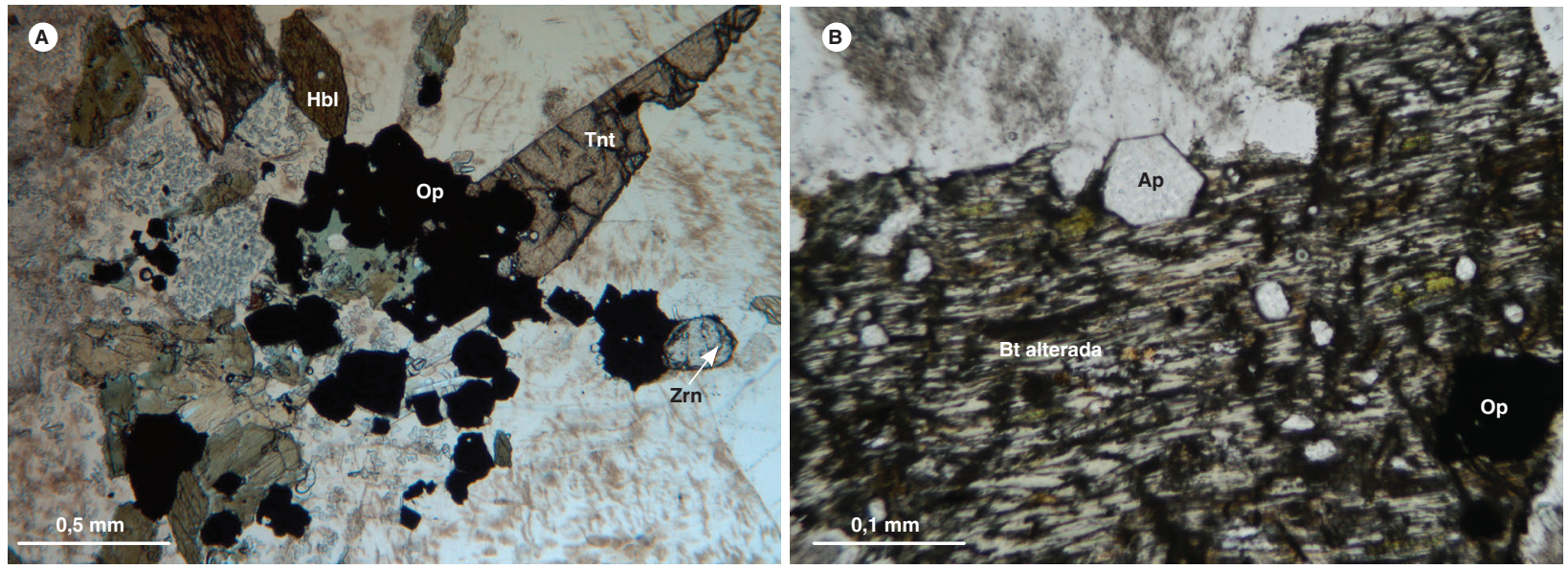

Figura 13. Microfotografías en las que se observa la forma en que aparecen la titanita, los opacos, el apatito y el circón en los monzogranitos del Batolito de Mogotes. A) IGM14355. Opacos (Op), titanita (Tnt), hornblenda (Hbl) y trazas de circón (Zrn). Nícoles paralelos. B) IGM13265. Inclusiones de apatito (Ap) y opacos (Op) en cristales alterados de biotita (Bt alterada). Nícoles paralelos 
Localmente muestra bordes interrumpidos por otros minerales. Puede presentar inclusiones de opacos, apatito y cuarzo. Se halla diseminada en la roca o como inclusión en el feldespato. Los tamaños comunes oscilan de $0,3 \times 0,4 \mathrm{~mm}$ a $0,25 \times 0,75 \mathrm{~mm}$, si bien algunos cristales pueden alcanzar 2,5 $\mathrm{mm}$ de largo.

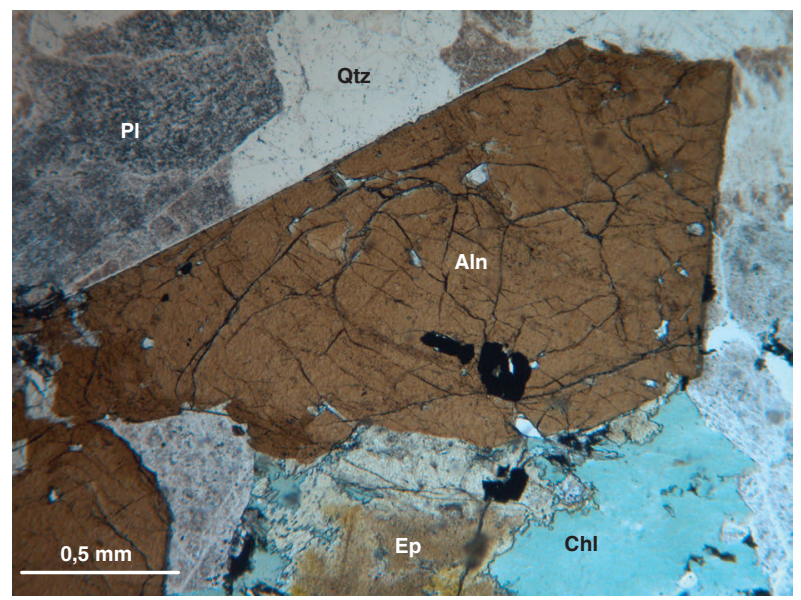

Figura 14. Microfotografía de un cristal de allanita de los monzogranitos del Batolito de Mogotes. IGM10905. Cristal subhedral de allanita (Aln). Nícoles paralelos

\subsubsection{Granodioritas-cuarzomonzodioritas}

Se analizaron once secciones delgadas de granodioritas (IGM 900902, 10906, 13263, 14356, 37307, 37690, $73671,73672,37300,73676$ y 14346) y dos de cuarzomonzodioritas (IGM 10909 y 900903).

Las granodioritas muestran textura hipidiomórfica inequigranular de grano medio (figura 15A). Localmente poiquilítica (figura 15B), donde el feldespato potásico encierra cristales menores de plagioclasa, biotita u hornblenda. Consisten de plagioclasa (38 a 47\%), cuarzo (20 a $30 \%$ ), feldespato potásico (15 a 22\%), anfíbol (0 a 14\%), biotita (0 a 13\%), y como minerales accesorios, opaco, titanita, apatito, circón y allanita. Son comunes los feldespatos potásicos con desmezclas pertíticas. Las cuarzomonzodioritas exhiben textura hipidiomórfica inequigranular, y una de las muestras (IGM900903) exhibe deformación dinámica, por lo que presenta una textura cataclástica con recristalización de cuarzo, que se describe en la parte final del capítulo dedicado a las granodioritas-cuarzomonzodioritas. En menor proporción se observan texturas poquilíticas en las que oikocristales de feldespato potásico encierran cristales de plagioclasa, biotita y opacos. Están compuestas por plagioclasa (52 a 55\%), feldespato potásico (10 a $20 \%)$, cuarzo (15\%), biotita (10 a $20 \%$ ), hornblenda (1\%), y como minerales accesorios se encuentran titanita, opacos, circón, apatito y allanita.

La plagioclasa se presenta en cristales subhedrales, de incoloros a empolvados por la alteración parcial a minerales de arcilla y sericita (figura 15B), y localmente, a saussurita. Maclas de tipo albita y albita-Carlsbad. Algunos cristales exhiben zonación. La composición de la plagioclasa en las granodioritas, estimada por el método Michel-Lévy, es oligoclasa-andesina entre $\mathrm{An}_{30} \mathrm{y}$ $\mathrm{An}_{42}$, mientras que en las cuarzomonzodioritas es oligoclasa-andesina $\mathrm{An}_{30}-\mathrm{An}_{31}$. El tamaño varía entre 0,3 mm y $2,5 \mathrm{~mm}$, si bien el rango predominante se encuentra entre 1 y $1,5 \mathrm{~mm}$.

El feldespato potásico es de tipo ortosa, se encuentra en cristales anhedrales de contornos irregulares, incoloros levemente parduzcos debido a una leve caolinización. Los cristales presentan textura pertítica en filoncillos (figura 15B). Localmente muestran textura poiquilítica con inclusiones de pequeños cristales de biotita, plagioclasa (alterada a sericita), hornblenda, cuarzo y titanita (figura 15B). Los tamaños varían entre 0,5 y $3 \mathrm{~mm}$, aunque predomina el rango entre $1,5 \mathrm{~mm}$ y $2 \mathrm{~mm}$.

El cuarzo se presenta en cristales anhedrales incoloros, y tiene extinción ondulatoria. Algunos cristales están fracturados y otros forman mosaicos de granos. Pueden tener pequeñas inclusiones de plagioclasa y hornblenda. El tamaño varía entre 0,5 y 2,5 $\mathrm{mm}$, pero predomina el rango entre 1 y $2 \mathrm{~mm}$.

La biotita se encuentra en láminas subhedrales a euhedrales con terminaciones fibrosas (figura 16A) de color pardo claro, con pleocroísmo a pardo rojizo. Las láminas varían de frescas a parcialmente alteradas a clorita y epidota. Algunas contienen inclusiones de cuarzo y circón. El tamaño varía entre 0,1 y $2 \mathrm{~mm}$, siendo el promedio de $1 \mathrm{~mm}$.

La hornblenda se halla en cristales euhedrales a subhedrales (figura 16 A y B) de color pardo-verdoso claro. El anfíbol se aprecia desde fresco, parcialmente alterado a epidota, hasta completamente alterado a clorita, epidota y cuarzo; conserva los contornos de cortes basales y longitudinales. Algunos cristales exhiben maclas (figura 16B). La hornblenda aparece en cristales diseminados en la roca, aunque también pueden estar agrupados en un enclave, como en la muestra IGM1 0909. Localmente se presentan acumulaciones de minerales opacos en zonas 

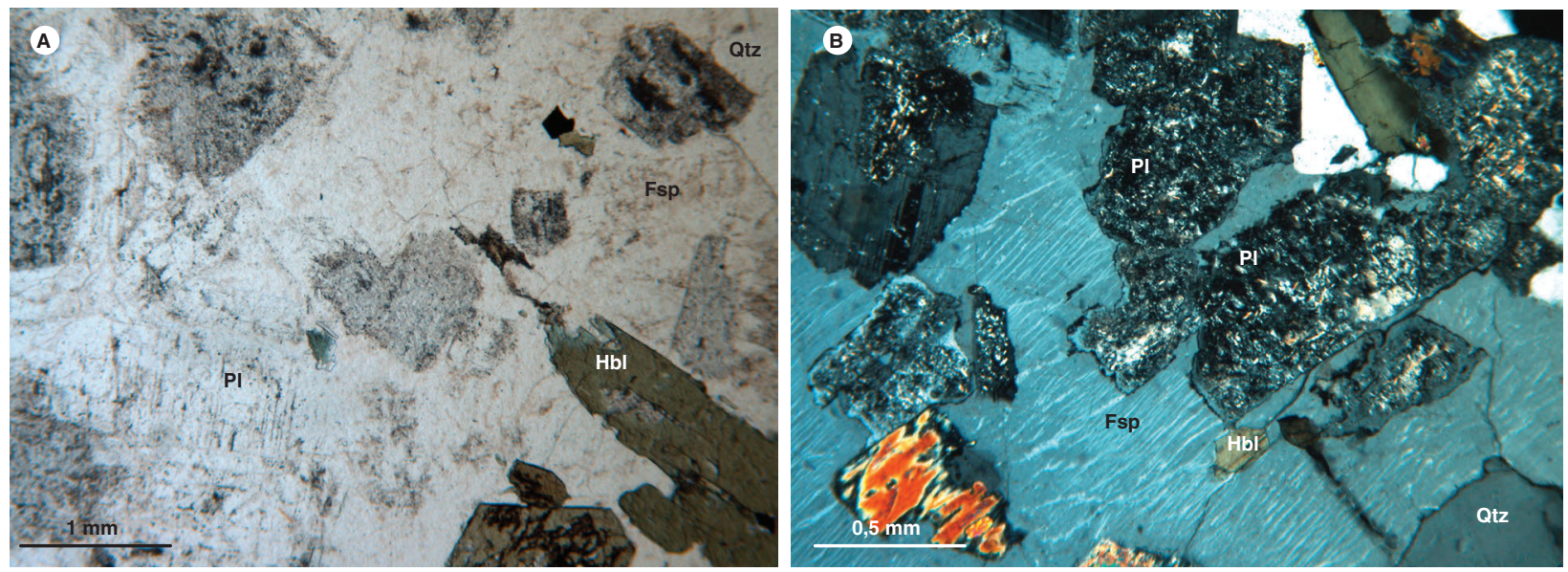

Figura 15. Fotomicrografías en las que se aprecian texturas de las granodioritas del Batolito de Mogotes. A) IGM900902. Textura hipidiomórfica inequigranular. Granodiorita compuesta por plagioclasa (PI), cuarzo (Qtz), feldespato potásico (Fsp) y hornblenda (Hbl). Nícoles paralelos. B) IGM10906. Textura poiquilítica, con inclusiones de plagioclasa $(\mathrm{Pl})$, biotita $(\mathrm{Bt})$ y hornblenda $(\mathrm{Hbl})$ en feldespato potásico $(\mathrm{Fsp})$, el cual tiene pertitas. Nícoles cruzados
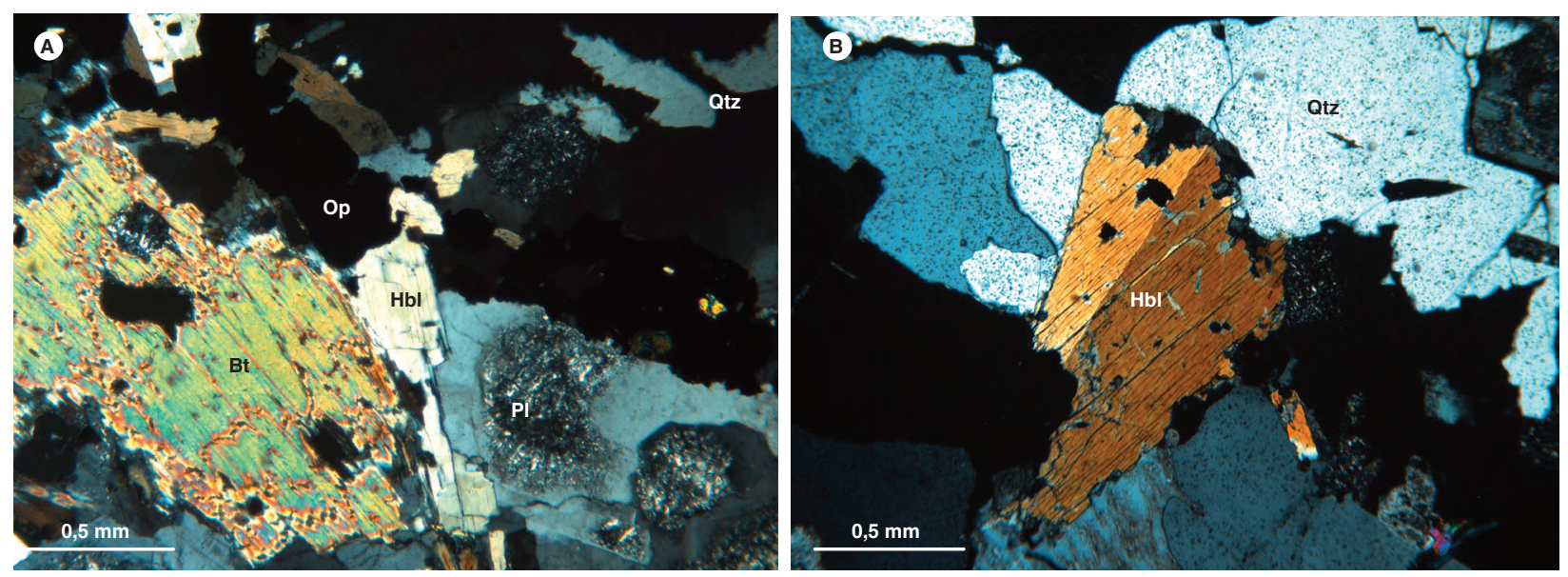

Figura 16. Microfotografías con características de la biotita y la hornblenda en las granodioritas del Batolito de Mogotes. A) IGM10906. Aspecto general de los cristales de biotita (Bt) y hornblenda (Hbl). Nícoles cruzados. B) IGM73672. Cristal maclado de anfíbol (Hbl). Nícoles cruzados
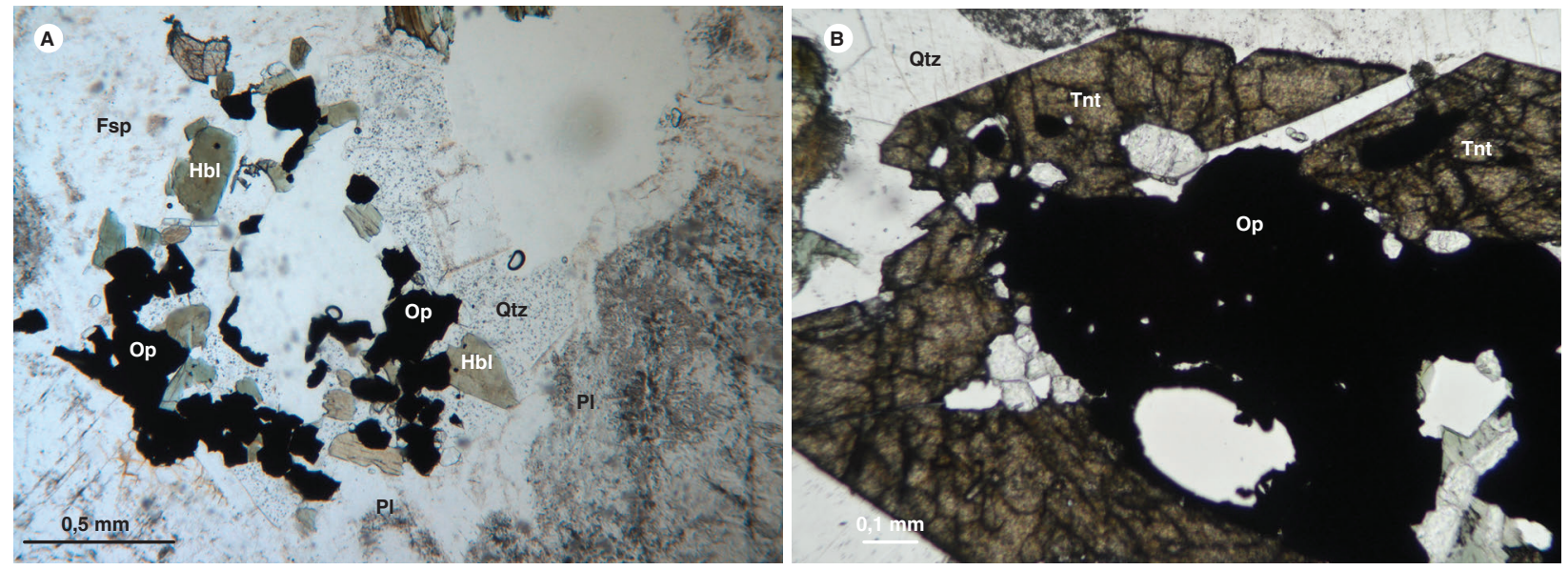

Figura 17. Microfotografías en las que se observa la forma de presentación de opacos y titanita en las granodioritas del Batolito de Mogotes. A) IGM10906. Cristales de opacos (Op) asociados a anfíbol (Hbl). Nícoles paralelos. B) IGM13263. Cristales de esfena (Tnt) y opacos (Op). Nícoles paralelos 
donde hay presencia de hornblenda, generalmente junto a esfena. El tamaño de cristales varía entre 0,5 y 1,5 mm, aunque los que están en el enclave (IGM1 0909) son de menor tamaño: entre 0,2 y $0,3 \mathrm{~mm}$.

Los opacos se encuentran en cristales muy finos a finos, anhedrales a subhedrales, diseminados en la roca, asociados a ferromagnesianos y a titanita (figura 17 A y B). El tamaño en general es menor de 0,2 mm.

La titanita se halla en cristales euhedrales rómbicos a subhedrales (figura 17B), algunos anhedrales, de color marrón oscuro, sin pleocroísmo. Suele estar asociada a los opacos y ferromagnesianos, principalmente a hornblenda. Su tamaño es menor de 0,4 mm.

El apatito se encuentra en cristales euhedrales prismáticos, de bordes rectos, incoloros. También se presenta como inclusiones en el feldespato de potasio y en la biotita. Puede tener inclusiones de epidota. Su tamaño varía entre 0,1 y $0,7 \mathrm{~mm}$.

El circón se presenta en cristales euhedrales incoloros, y se encuentra incluido en plagioclasa, cuarzo y biotita. Su tamaño oscila entre 0,1 y 0,3 mm.
En algunas muestras, la allanita se encuentra en cristales euhedrales de color pardo con pleocroísmo a pardo verdoso. Puede estar rodeada por una corona de epidota. Su tamaño varía entre 0,3 y 0,8 mm.

La muestra, clasificada como metacuarzomonzodiorita (IGM900903), tiene composición similar a las ya descritas, pero se diferencia de estas en que exhibe rasgos de deformación dinámica, con agregados de cuarzo recristalizado y láminas de biotitas cloritizadas dobladas, estiradas y localmente alineadas.

\section{Características microscópicas de cuerpos menores}

De cuerpos menores se analizaron cinco secciones delgadas: una del monzogranito del sector de Tempranito (IGM900942) y cuatro de sienogranitos del sector de Los Trapiches (IGM 900875, 10904, 10912 y 10913). El resumen de la composición modal se presenta en la tabla 2, y la composición modal se grafica en la figura 18.

Tabla 2. Composición modal de cuerpos menores y diques del Batolito de Mogotes

\begin{tabular}{|c|c|c|c|c|c|c|c|c|c|c|c|c|c|c|c|c|}
\hline Igm & w & 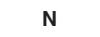 & Qtz & PI & Fsp & $\mathrm{Hbl}$ & $\mathrm{Bt}$ & Ms & Grt & Op & Ap & Zrn & Ttn & Matriz & Otros & Clasificación \\
\hline 900942 & 1122841 & 1230947 & 26,2 & 29,1 & 38,7 & & 6 & $\operatorname{Tr}$ & & $\operatorname{Tr}$ & $\operatorname{Tr}$ & $\operatorname{Tr}$ & & & & $\begin{array}{l}\text { Monzogranito } \\
\text { micrográfico }\end{array}$ \\
\hline 900875 & 1136936 & 1202313 & 25,5 & 12,5 & 60 & & 1 & $\operatorname{Tr}$ & & 1 & & & & & & $\begin{array}{l}\text { Sienogranito } \\
\text { aplítico }\end{array}$ \\
\hline 10904 & 1136722 & 1202554 & 35 & 22 & 40 & & $\operatorname{Tr}$ & $\operatorname{Tr}$ & & $\operatorname{Tr}$ & & $\operatorname{Tr}$ & & & 3 & $\begin{array}{l}\text { Monzogranito } \\
\text { en límite con } \\
\text { sienogranito }\end{array}$ \\
\hline 10912 & 1134224 & 1205402 & 28,5 & 22 & 45 & & 3 & & & 1,5 & & 0,5 & & & & Sienogranito \\
\hline 10913 & 1134462 & 1203358 & 33 & 27 & 35 & & 3 & & & 2 & & 0,5 & & & & Monzogranito \\
\hline 900904 & 1141272 & 1208004 & 34,8 & 38,1 & 14,1 & & 1 & 1,1 & & $\operatorname{Tr}$ & & & & 10,5 & & Metagranodiorita \\
\hline 900888 & 1129973 & 1218837 & 31,2 & 30,6 & 38,2 & & $\operatorname{Tr}$ & & & $\operatorname{Tr}$ & $\operatorname{Tr}$ & $\operatorname{Tr}$ & & & & Monzogranito \\
\hline 900889 & 1134866 & 1203574 & 36,2 & 36,8 & 25,0 & & & $\operatorname{Tr}$ & 2,0 & $\operatorname{Tr}$ & & $\operatorname{Tr}$ & $\operatorname{Tr}$ & & & Monzogranito \\
\hline 900901 & 1140288 & 1204364 & 45,4 & 6,1 & 46,6 & & 1 & & & 0,5 & & & & & & Sienogranito \\
\hline 900963 & 1124265 & 1231161 & 28 & 17,5 & 51,5 & & 2 & & & 1 & & & & & & Sienogranito \\
\hline 900915 & 1137541 & 1202175 & 33,5 & 12,5 & 48,6 & & 4 & 1,4 & & $\operatorname{Tr}$ & $\operatorname{Tr}$ & $\operatorname{Tr}$ & & & & Sienogranito \\
\hline 900868 & 1123996 & 1238967 & 12 & 40 & & & & & & & & Tr? & & 35 & 5 & Microtonalita \\
\hline 10907 & 1139123 & 1200431 & 12 & 50 & & 35 & & & & 1 & 0,5 & & 1,5 & & & Tonalita \\
\hline 10908 & 1138984 & 1200113 & 3,5 & 49 & & 41 & & & & 5,5 & & & 1 & & & Andesita \\
\hline 37711 & 1124220 & 1238720 & & 86 & & 2 & & & & 0,5 & & & 0,5 & & 11 & $\begin{array}{c}\text { Andesita } \\
\text { hornbléndica }\end{array}$ \\
\hline 900926 & 1122453 & 1222482 & 6 & 55 & 39 & & & & & $\operatorname{Tr}$ & & $\operatorname{Tr}$ & & & & $\begin{array}{c}\text { Cuarzolatita límite } \\
\text { con latita }\end{array}$ \\
\hline 900964 & 1124265 & 1231161 & 15 & 37,5 & 36,5 & 9 & & & & 2 & & & & & & Fenocuarzolatita \\
\hline 13246 & 1126681 & 1229783 & 8 & 6 & 4,5 & & 2 & & & & & & & 80 & & Fenorriolita \\
\hline 900914 & 1137541 & 1202175 & 14 & 3,7 & 17,6 & & 1 & & & $\mathrm{Tr}$ & & $\operatorname{Tr}$ & $\operatorname{Tr}$ & 62 & 1,37 & Riolita \\
\hline
\end{tabular}



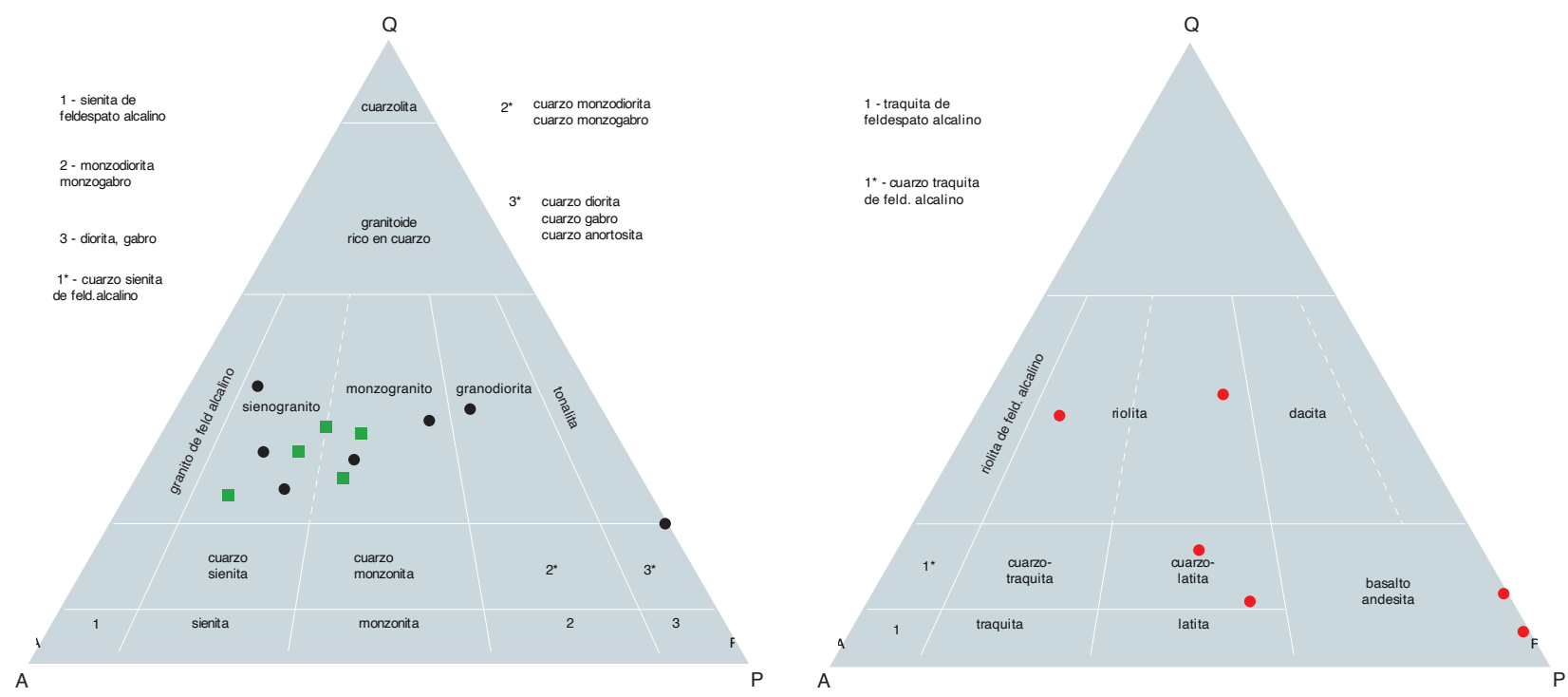

Figura 18. Diagramas de clasificación de cuerpos menores y diques A la izquierda, composición modal de los cuerpos menores (cuadrados verdes) y de los diques plutónicos (círculos negros), en el triángulo de Streckeisen (1974). A la derecha, composición modal de los diques subvolcánicos (círculos rojos) en el triángulo de Streckeisen (1978)

Cuerpo menor de monzogranito en borde $W$ en vía Aratoca-La Palma

Este cuerpo está representado por un monzogranito granofídico (muestra IGM900942). La textura granofídica (figura 20) se presenta como intercrecimientos en los bordes de los cristales de feldespato, cuarzo y plagioclasa que se conservan en forma de núcleos. La roca consiste de feldespato potásico (39\%), plagioclasa (29\%), cuarzo (26\%), biotita (6\%) y, como accesorios, opacos, apatito y circón. En la muestra se distingue una matriz microgranular equigranular aplítica con cristales de tamaños que fluctúan entre 0,1 y 0,2 mm, de color pardo (figura 19). Esta matriz está compuesta por feldespato con alteración a caolín y cuarzo que contrasta por ser cristales limpios sin alteración, y en menor proporción plagioclasa. Se aprecian texturas de reacción entre la matriz y cristales de feldespato y cuarzo con bordes en bahías y cristales corroídos.

El feldespato potásico es ortosa y aparece en cristales anhedrales de aspecto sucio, alterados a caolín, en tamaños que fluctúan entre 0,7 y $1 \mathrm{~mm}$, y presentan maclas tipo Carlsbad. También está en intercrecimientos con el cuarzo, formando texturas micrográficas. Láminas finas de moscovita se encuentran intersticiales entre cristales de cuarzo y feldespato, posiblemente como producto de alteración de feldespato.

La plagioclasa está en cristales finos tabulares en la matriz y muestra maclas tipo albita. En cristales de mayor tamaño $(0,5 \mathrm{~mm})$ muestra maclas tipo Carlsbad, y alteración a sericita y epidota. Exhibe texturas mirmequíticas hacia los bordes por intercrecimiento con feldespato y cuarzo. Según el método Michel-Lévy, la composición es andesina $\left(\mathrm{An}_{34}\right)$.

El cuarzo aparece en cristales desde anhedrales (figura 19B) hasta euhedrales bipiramidales, rodeados por intercrecimientos micrográficos de cuarzo y feldespato, con formas de cuñas triangulares. Hacia los bordes de los cristales pueden presentarse finas láminas de biotita. Los tamaños varían entre 0,2 y 0,5 mm.

La biotita aparece en láminas euhedrales tabulares de color pardo, pleocroicas de pardo amarillento a amarillo claro, con extinción ojo de pájaro. Se hallan hacia los bordes de los cristales de cuarzo, plagioclasa y feldespato, y en nidos a los que se asocian cristales de clinozoisita. El tamaño es fino, de aproximadamente 0,05 mm. 

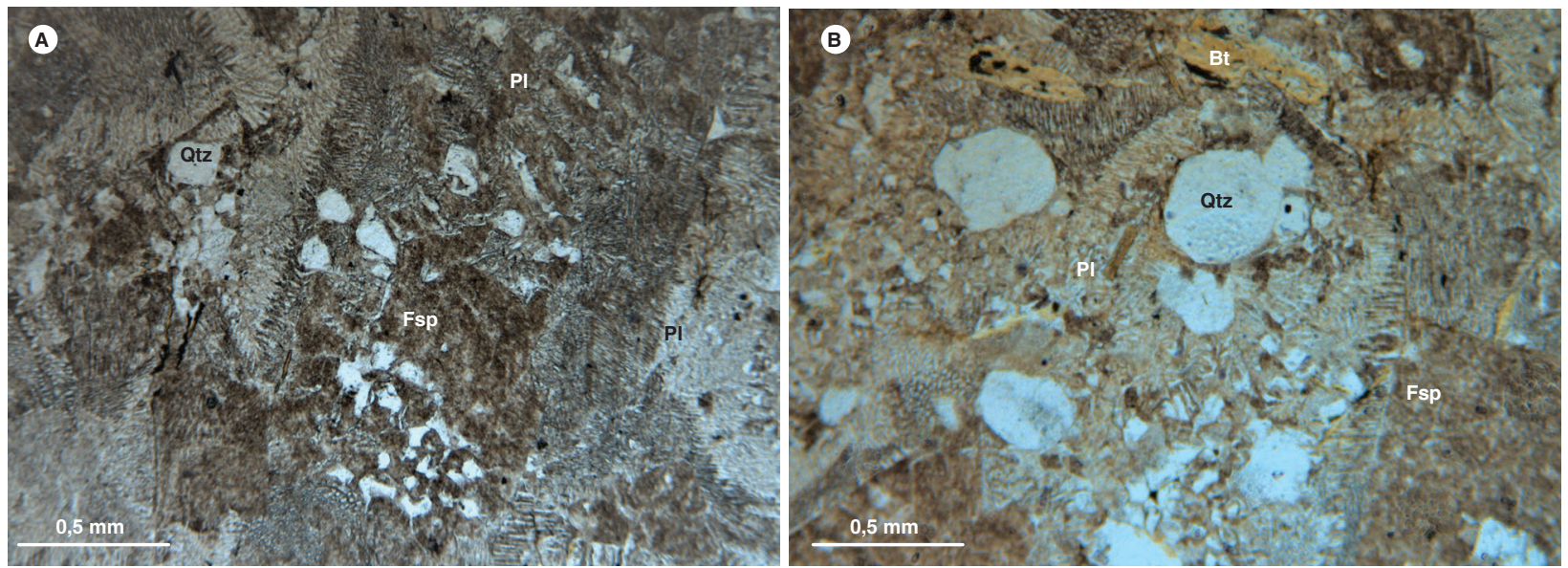

Figura 19. Microfotografías en las que se muestra la textura granofídica en cuerpo menor de monzogranito en vía Aratoca-La Palma. A) IGM900942. Textura holocristalina granofídica, dada por intercrecimientos micrográficos de cuarzo (Qtz) y feldespato potásico (Fsp). Nícoles paralelos. B) IGM900942. Textura granofídica inequigranular compuesta por cuarzo (Qtz) e intercrecimientos micrográficos. Además, láminas de biotita (Bt). Nícoles paralelos

Los opacos son escasos en la muestra y se presentan como cristales isotrópicos de tamaño fino (0,05 mm), incluidos en láminas de biotita.

El circón se presenta en cristales euhedrales prismáticos, se encuentra en los nidos de láminas de biotitas y junto a epidota/clinozoisita. El apatito está en cristales euhedrales prismáticos cortos, incoloros, de 0,05 mm, incluidos en plagioclasa y cuarzo.

\section{Cuerpo menor de sienogranito en Los Trapiches}

Este cuerpo está compuesto por sienogranitos, monzogranitos y monzogranitos en el límite con sienogranitos (IGM 900875, 10904, 10912 y 10913). Consisten de feldespato potásico (35 a $60 \%$ ), cuarzo (25,5 a $35 \%$ ), plagioclasa (12,5 a $27 \%$ ), biotita (desde trazas hasta $2,5 \%$ y como minerales accesorios moscovita, circón y opacos. La textura predominante es la alotriomórfica inequigranular (figura 20A), y de manera subordinada la textura micrográfica (figura 20B); también son comunes las pertitas en los feldespatos potásicos. Los principales minerales de alteración son arcilla (caolín), epidota y sericita. En algunas muestras se aprecian microfracturas y microfallas rellenas de cuarzo finogranular.

El feldespato potásico es ortosa y aparece en cristales anhedrales de incoloros a levemente parduzcos por alteración a caolín. Muchos presentan textura pertítica por desmezcla de plagioclasa en forma de cordones (figura 20A); algunos tienen inclusiones de cuarzo, y otros muestran textura micrográfica (figura 20B). En algunos cristales se insinúa zonación hacia los bordes. Se encuen- tran cristales con macla de Carlsbad. Los tamaños varían desde $0,5 \times 1 \mathrm{~mm}$ hasta $1,5 \times 2,5 \mathrm{~mm}$, si bien los tamaños predominantes están entre 0,5 y $1 \mathrm{~mm}$.

La plagioclasa se aprecia en cristales subhedrales (figura 20A) a anhedrales, incoloros a levemente parduzcos por alteración a sericita, y localmente, a saussurita. Presentan macla de albita en ocasiones mal definida, y Carlsbad. Su composición por el método Michel-Lévy varía entre oligoclasa $\mathrm{An}_{28}$ a andesina $\mathrm{An}_{34}$. Los tamaños varían desde $0,25 \times 0,5 \mathrm{~mm}$ a $0,5 \times 1 \mathrm{~mm}$, y en general son menores que los cristales de feldespato potásico.

El cuarzo se halla en cristales anhedrales (figura 20 A y B), incoloros, con extinción ondulatoria. Se encuentra en los intersticios de cristales de feldespato potásico, plagioclasa y otros cuarzos. En algunas muestras se presentan "gotas" alargadas e irregulares de cuarzo en la ortoclasa que forman textura gráfica (figura 20B). Los tamaños varían entre 0,2 y $1,5 \mathrm{~mm}$, aunque en promedio son menores de $0,8 \mathrm{~mm}$ en su dimensión mayor.

La biotita, presente en láminas subhedrales, es pleocroica de pardo a amarillo claro, con extinción ojo de pájaro. Color de interferencia azul de segundo orden. Puede estar levemente alterada a clorita y presentar un poco de alteración a moscovita en sus bordes. Los tamaños varían desde $0,1 \times 0,15 \mathrm{~mm}$ hasta 0,12 x 1,75 mm.

La moscovita es escasa y solo se encuentra en algunas muestras. Se encuentra presente en láminas subhedrales, con tonalidad verde pálido, relieve variable, $\mathrm{y}$ aparece entre cristales de cuarzo y feldespato potásico. Su tamaño promedio es de 0,25 x 0,5 mm. 

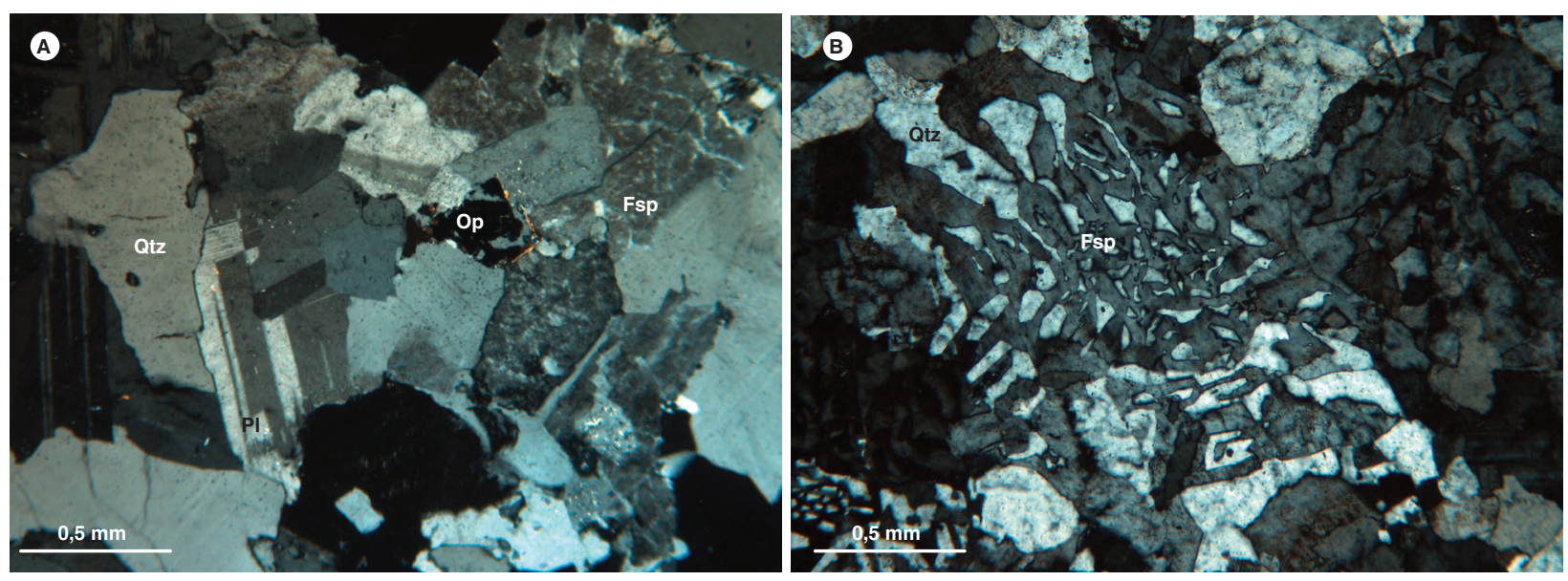

Figura 20. Microfotografías en las que se observan rasgos texturales y los minerales principales del cuerpo menor sienogranito de Los Trapiches. A) IGM10904. Textura alotriomórfica inequigranular, con sus minerales principales: cuarzo (Qtz), plagioclasa (PI), feldespato potásico (Fsp) y, como mineral accesorio, opaco (Op). Nícoles cruzados. B) IGM900875. Feldespato potásico (Fsp) intercrecido con cuarzo, en una textura micrográfica. Nícoles cruzados

Los opacos se presentan en poca cantidad, principalmente en cristales anhedrales con tendencia a ser equidimensionales $(0,15 \times 0,2 \mathrm{~mm})$, diseminados por toda la roca y asociados a biotita. Escasos cristales subhedrales son alargados, de $0,05 \times 0,25 \mathrm{~mm}$.

El circón aparece en poca cantidad, en cristales euhedrales prismáticos incoloros; sus tamaños fluctúan entre 0,05 y $0,1 \mathrm{~mm}$.

\subsubsection{Características microscópicas de diques}

De diques distribuidos por todo el batolito, se analizaron catorce secciones delgadas (IGM 10907, 10908, 13246, 37711, 900868, 900926, 900901, 900963, 900964, 900904, 900889, 90091 4, 900915 y 900888). El resumen de la composición modal se presenta en la tabla 2, y la composición modal se grafica en la figura 18. Para la clasificación de los cristales según los tamaños, en rocas en las que se distinguen fenocristales y matriz, se usan los siguientes rangos: fenocristales, $\geq 2 \mathrm{~mm}$; microfenocristales, entre 2 y $0,5 \mathrm{~mm}$, y microcristales, $<0,5 \mathrm{~mm}$.

\subsubsection{Dique de metagranodiorita}

La metagranodiorita (IGM900904) tiene textura granoporfidoclástica y cataclástica (figura 21). Se caracteriza por ser fracturada con porfidoclastos de minerales de la roca ígnea original, con tamaño $\leq 2,5 \mathrm{~mm}$, y una matriz finogranular $(\leq 0,1 \mathrm{~mm})$ resultante de la blastesis y trituración de la roca, con cuarzo recristalizado con individualización de subgranos formando bandas de deformación frágil junto con las micas blancas, biotita, plagioclasa y feldespato potásico (figura 21). Consiste de plagioclasa (38\%), feldespato potásico (14\%), cuarzo $(35 \%)$, biotita $(1,5 \%)$, mica blanca (1\%) y matriz $(10,5 \%)$, así como trazas de opaco. Los minerales de alteración son arcilla, sericita y clorita.

La plagioclasa está en cristales incoloros, cuando su superficie está fresca, a parduzcos con aspecto sucio por alteración a minerales de arcilla y sericita (figura 21), subhedrales con bordes irregulares; con maclas mal conservadas de albita, albita-Carlsbad y periclina, parcialmente cubiertas por minerales de alteración o sin maclas. Según el método Michel-Lévy, su composición es oligoclasa $\left(\mathrm{An}_{29}\right)$. Localmente muestra inclusiones de biotita. Su tamaño es menor de 2,5 mm.

El feldespato aparece en cristales anhedrales inequigranulares con contornos irregulares, superficie parduzca por alteración a caolín, sin maclas. Algunas maclas de microclina presentan abundantes desmezclas pertíticas en cordoncillos y textura micrográfica. Se presenta con microfracturas, algunas rellenas de mica blanca. Su tamaño es menor de $3 \mathrm{~mm}$.

El cuarzo se presenta en cristales anhedrales (figura 21). Forma cristaloblastos y agregados poligonales con puntos triples (granoblástica poligonal) y bandas lenticulares de subgranos con bordes irregulares, con extinción ondulatoria en cristales individuales y en mosaico, en las bandas de cuarzo. El tamaño en general es menor de $1 \mathrm{~mm}$. Los cristales de menor tamaño forman unas bandas que se pliegan junto con las micas. 

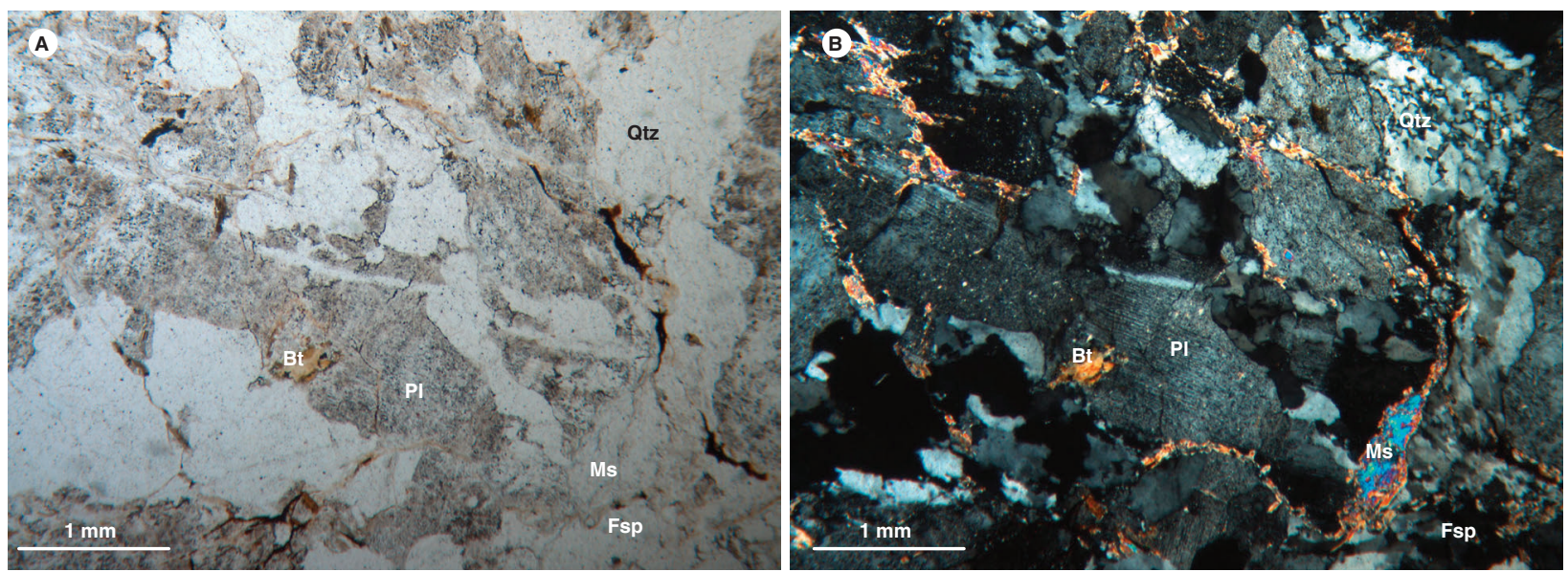

Figura 21. Microfotografías de las características petrográficas de un dique de metagranodiorita en el Batolito de Mogotes. A) IGM900904. Textura granoporfidoclástica y cataclástica. Roca compuesta por feldespato potásico (Fsp), cuarzo (Qtz), plagioclasa (PI), moscovita (Ms) y biotita (Bt). Nícoles paralelos. B) IGM900904. El mismo campo de la fotomicrografía de la izquierda, pero con nícoles cruzados

La biotita se halla en pequeñas láminas anhedrales (figura 21) de hábito fibroso, de color pardo claro con pleocroísmo a pardo oscuro, exfoliación en una dirección, relieve moderado, color de interferencia verde del segundo orden, con extinción paralela, parcialmente alterada a clorita y opaco. Su tamaño varía entre 0,3 y $0,5 \mathrm{~mm}$.

La moscovita se observa en láminas anhedrales dobladas, con tamaños menores de 0,5 mm. Forma delgadas bandas lenticulares plegadas (figura 21) e intergranulares junto con la biotita y el cuarzo microcristalino recristalizado. También se presenta como microinclusiones en la plagioclasa y rellenando microfracturas.

\subsubsection{Diques de monzogranitos y sienogranitos}

De muestras de diques de monzogranito se analizaron dos secciones delgadas (IGM 900888 y 900889), y de sienogranitos, tres (IGM 900901, 900963 y 900915). Estos presentan texturas alotriomórficas e hipidiomórficas equigranulares de grano fino (figura 22). Otra textura común son las pertitas en ortosa en forma de filoncillos (figura 22A). En algunas se aprecia además textura micrográfica. La muestra IGM900889 muestra textura poiquilítica en granate (figura 22B). Están compuestas por feldespato potásico (25 a $52 \%$ ), cuarzo (28 a $45 \%$ ), plagioclasa (7 a $37 \%$ ), biotita (desde trazas hasta $4 \%$ ), trazas de opacos y escasos cristales de apatito y circón. La muestra IGM900889 contiene $2 \%$ de granate. Como minerales de alteración se encuentran sericita, arcilla, clorita, titanita y epidota-clinozoisita.
El feldespato potásico corresponde a ortosa y se presenta en cristales anhedrales de contornos irregulares, de superficie ligeramente parduzca por alteración a caolín. Puede exhibir desmezclas pertíticas en filoncillos irregulares (figura 22 A y C) y parches e intercrecimientos gráficos con cuarzo a manera de gotas y vermicular gruesa. En general, no presenta desarrollo de maclas, aunque en algunos casos muestra maclas de tipo Carlsbad, y en otros desarrollan maclas incipientes de microclina. Puede presentar bordes de reacción con las plagioclasas. En los bordes de contacto entre cristales de feldespato se acumulan agregados finos de plagioclasa. Los tamaños más comunes están entre 0,2 y $1 \mathrm{~mm}$, pero pueden alcanzar $4 \mathrm{~mm}$ en su dimensión mayor.

El cuarzo aparece en cristales anhedrales con bordes irregulares (figura 22), incoloros, con extinción ondulatoria de débil a fuerte. Localmente está intercrecido con ortosa, y en ocasiones, con plagioclasa. Los tamaños varían desde 0,15 hasta $3,7 \mathrm{~mm}$, si bien predominan los menores de $2 \mathrm{~mm}$.

La plagioclasa se presenta en cristales euhedrales tabulares cortos a anhedrales (figura $22 \mathrm{~A}, \mathrm{C} \mathrm{y} \mathrm{D);} \mathrm{en}$ algunas muestras pueden estar levemente doblados. La superficie varía de incolora, cuando los cristales están frescos, a parduzca por alteración a arcilla y sericita. Se presenta con maclas de albita, albita-Carlsbad y localmente de la periclina, mal desarrolladas en los bordes. Según el método Michel-Lévy su composición es de oligoclasa $\left(\mathrm{An}_{28}\right)$ a andesina $\left(\mathrm{An}_{35}\right)$. Algunos exhiben zonación y los núcleos están más alterados que los bordes, 

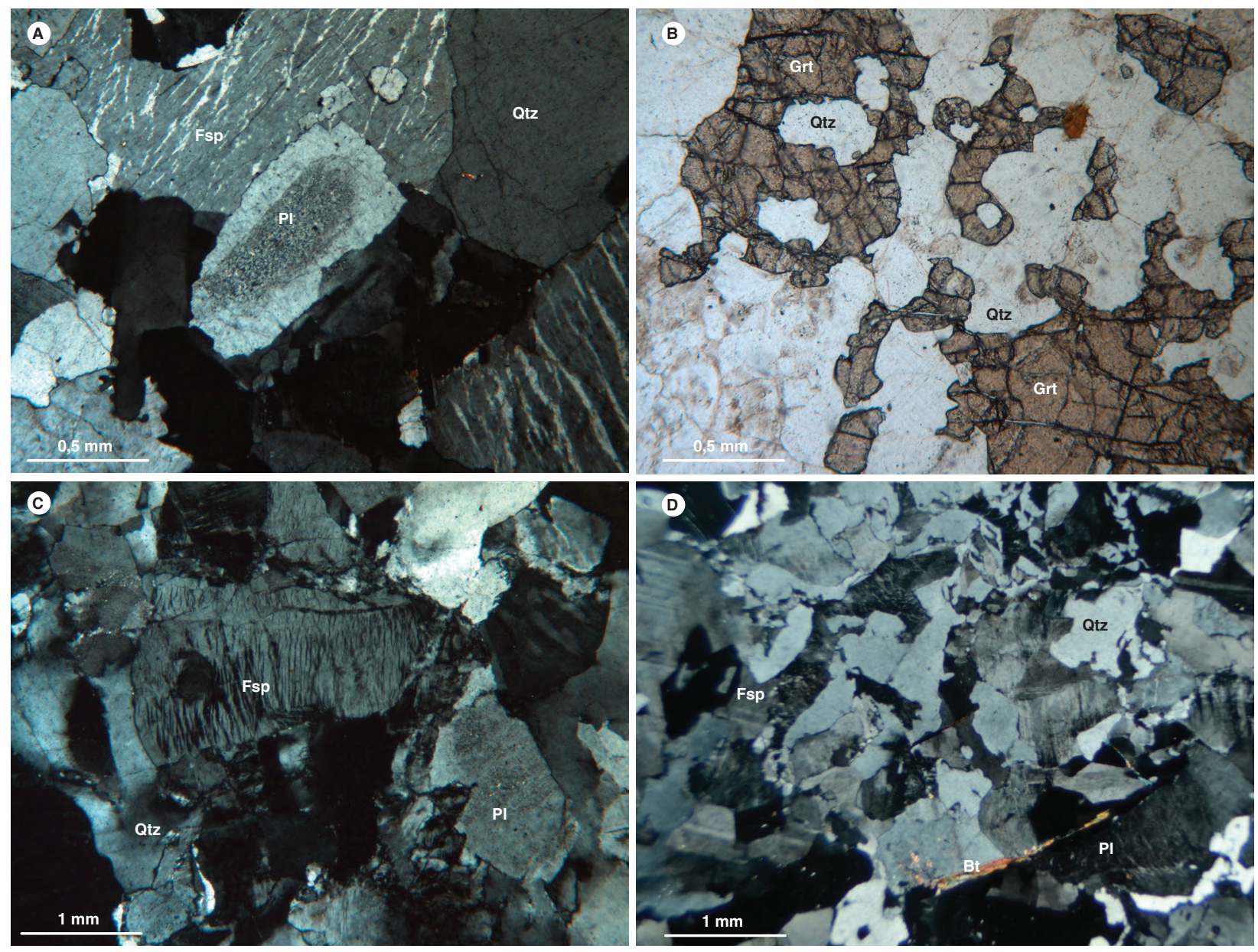

Figura 22. Microfotografías que muestran características petrográficas de diques de monzogranitos y sienogranitos en el Batolito de Mogotes. A) IGM900888. Cristales de plagioclasa (PI), feldespato alcalino (Fsp) con desmezclas pertíticas y cuarzo (Qtz) en un dique de monzogranito. Nícoles cruzados. B) IGM900889. Cristales de granate (Grt) poiquilíticos con inclusiones de cuarzo (Qtz), en dique de monzogranito. Nícoles paralelos. C) IGM900901. Textura hipidiomórfica inequigranular de un dique de sienogranito compuesto principalmente por plagioclasa (PI), cuarzo (Qtz) y feldespato potásico (Fsp). Nícoles cruzados. D) IGM900963. Textura hipidiomórfica equigranular de un dique de sienogranito compuesto por plagioclasa (PL), cuarzo (Qtz), feldespato potásico (Fsp) y biotita (Bt). Nícoles cruzados

reemplazados por sericita en agregados, saussurita y arcilla. Puede estar incluida en feldespato potásico y presenta bordes de reacción. Los tamaños predominantes están entre 0,2 y 1,5 mm, y de manera esporádica se encuentran cristales mayores. La biotita se halla en láminas subhedrales (figura 23D) a anhedrales, pocas euhedrales, de color pardo, con inclusiones de apatito, opacos, allanita y circón. Se altera a clorita en los bordes y a epidota; puede pasar a moscovita, y a lo largo del clivaje se forman magnetita y titanita residual. El tamaño de cristales varía entre 0,1 y 0,5 $\mathrm{mm}$.

Los opacos son principalmente anhedrales, diseminados en la roca o en zonas de alteración de la biotita. De forma esporádica aparecen junto a biotita, circón y apatito, y pueden tener inclusiones de apatito y cristales de circón en sus bordes. Los tamaños predominantes están entre 0,1 y $0,25 \mathrm{~mm}$.

El apatito es escaso y solo se observó en dos muestras, en cristales incoloros, generalmente en cortes basales hexagonales, incluidos en biotita y en opacos, principalmente. Su diámetro está por debajo de $0,1 \mathrm{~mm}$.

El circón también es escaso en estas muestras. Aparece en cristales euhedrales prismáticos, con color de interferencia de segundo orden. Muestra microfracturas. Está junto a opacos e incluido en biotita. Su tamaño es menor de $0,12 \mathrm{~mm}$.

La moscovita se encontró en dos muestras (IGM900889 e IGM900915), donde se presenta en láminas finas anhedrales a subhedrales. Algunas incluidas dentro de plagioclasa, otras individuales. Es incolora, 
con bordes irregulares, algunos de sus cristales con inclusiones de biotita, o pasan gradualmente de biotita a moscovita en los bordes.

El granate también se apreció solo en una muestra (IGM900889) (figura 22B). Se presenta en cristales más gruesos que los minerales principales, anhedrales, con crecimiento intersticial entre los cristales de cuarzo, de relieve alto, color rosado, microfracturas irregulares internas e inclusiones poiquilíticas de cuarzo, con contornos irregulares. El tamaño del mayor es aproximadamente de $0,8 \times 1,6 \mathrm{~mm}$.

\section{Diques de tonalita}

El dique IGM1 0907 se clasifica como una tonalita. Presenta una textura subidiomórfica inequigranular (figura 23) de grano fino y está compuesto por plagioclasa (45\%), hornblenda (29\%), cuarzo (23\%) y titanita, opacos y apatito, que suman el $3 \%$ restante. A diferencia de la muestra IGM900868, la plagioclasa y el anfíbol están preservados.

La plagioclasa se aprecia en cristales subhedrales incoloros (figura 23) a localmente parduzcos en los lugares donde presentan moderada a fuerte alteración a sericita. En algunos cristales localmente es posible ver maclas polisintéticas. Su composición, según el método Michel-Lévy, es andesina $\left(\mathrm{An}_{32}\right)$. En la mayoría de los casos exhibe epidotización, especialmente en el centro de los cristales, dejando una textura esquelética de las plagioclasas hacia los bordes. Los tamaños varían entre 0,3 y $1 \mathrm{~mm}$.

La hornblenda está en cristales euhedrales a subhedrales de color pardo claro (figura 23) con pleocroísmo a pardo. Localmente se presentan cristales maclados. La mayoría de cristales presentan una alteración a clorita entre leve y moderada (figura 24) y epidota. Titanita y opacos aparecen en zonas en donde las hornblendas se encuentran más alteradas. El tamaño de los cristales varía entre 0,3 y $1,5 \mathrm{~mm}$.

El cuarzo se halla en cristales anhedrales incoloros. Aparece intersticialmente entre los cristales de plagioclasa y hornblenda. El tamaño de los cristales no varía mucho, en el margen de 0,2 y $0,4 \mathrm{~mm}$.

La titanita se presenta en cristales subhedrales de color pardo claro, con colores de interferencia de azul a rosado de tercer orden. Se encuentra generalmente asociada a los minerales producto de alteración de la hornblenda. El tamaño de sus cristales varía entre 0,3 y 0,7 mm.

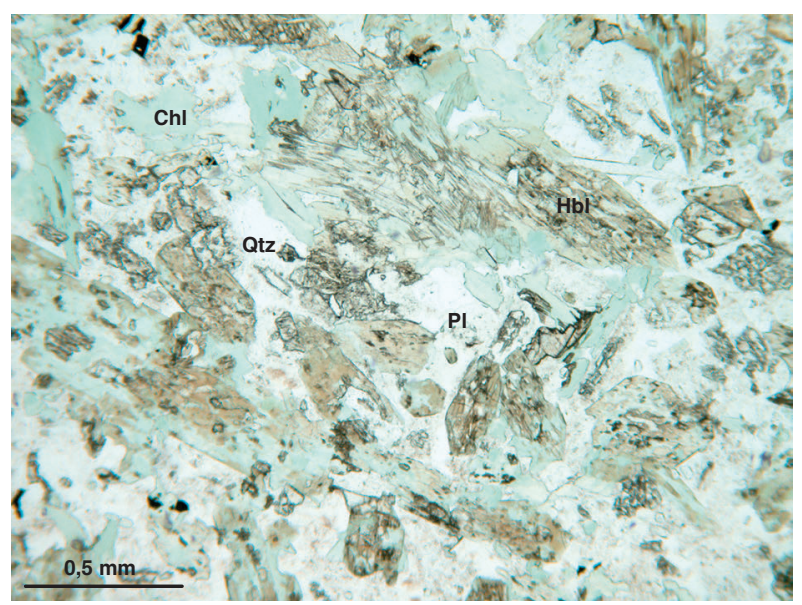

Figura 23. Microfotografía en la que se aprecian la textura y los minerales de un dique de tonalita en el Batolito de Mogotes. IGM10907. Textura subidiomórfica inequigranular con minerales primarios: plagioclasa $(\mathrm{PI})$, cuarzo $(\mathrm{Qtz})$ y hornblenda $(\mathrm{Hbl})$, y secundarios: clorita (Chl). Nícoles paralelos

Los opacos se observan en cristales euhedrales a subhedrales de color negro (probablemente de pirita) y anhedrales de color rojo (probablemente de hematita). Los cristales se encuentran en zonas de alteración de ferromagnesianos y en general diseminados en toda la roca. El tamaño de los cristales es menor de 0,3 $\mathrm{mm}$.

El apatito está en cristales incoloros euhedrales, isotrópicos en corte basal. Su tamaño es menor de 0,2 mm.

El dique de microtonalita alterada (IGM900868) corresponde a una roca en la que la textura original fue obliterada por la alteración hidrotermal (figura 24). Consiste de epidota-clinozoisita, un ferromagnesiano alterado a clorita, cuarzo primario y de introducción, y calcita. De acuerdo con los porcentajes estimados de minerales, su clasificación modal corresponde a tonalita en límite con cuarzo-diorita, pero por los minerales de alteración parece que originalmente correspondía a una roca de composición más básica, posiblemente una cuarzodiorita. Tiene fracturas menores de $0,5 \mathrm{~mm}$ de ancho, rellenas con los siguientes minerales de introducción: epidota-clinozoisita, cuarzo, calcita y clorita. Otras más finas están rellenas de calcita.

La epidota-clinozoisita se presenta en cristales anhedrales de epidota y subhedrales prismáticos o tabulares de clinozoisita, principalmente dispuestos en agregados irregulares (figura 24). Corresponde posiblemente al resultado de alteración hidrotermal de plagioclasa o de algún ferromagnesiano, o de ambos. El tamaño predominante es menor de 0,5 mm en su dimensión mayor. 


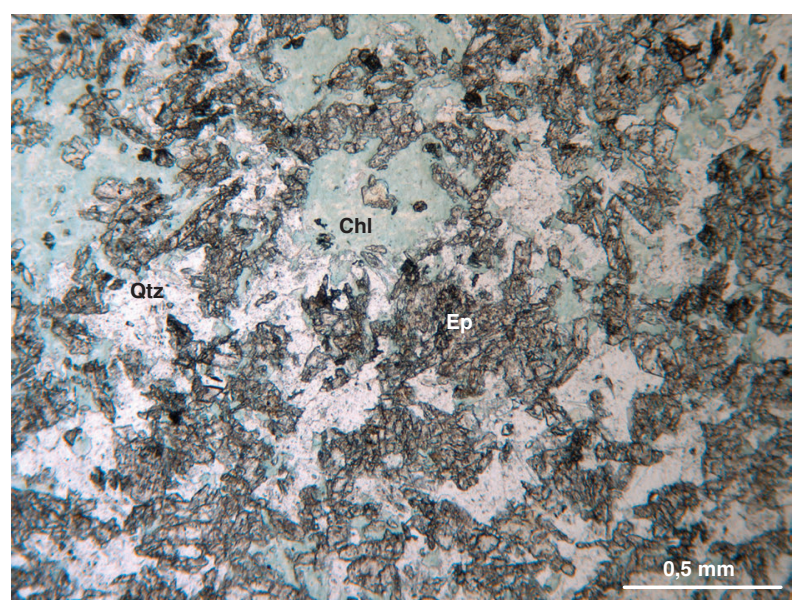

Figura 24. Microfotografía en la que se observan las características de un dique de microtonalita del Batolito de Mogotes. IGM900868. Microtonalita fuertemente alterada a epidota (Ep) y clorita (Chl). Contiene cuarzo (Qtz). Nícoles paralelos

La clorita es de hábito fibroso, color verde claro (figura 24), con leve pleocroísmo. El color de interferencia es pardo anómalo. Puede corresponder a un ferromagnesiano alterado.

El cuarzo aparece en cristales anhedrales entre los otros minerales (figura 24) y rellenando fracturas. En los que se encuentran en los intersticios, algunos tienen extinción ondulatoria moderada, que puede corresponder a minerales primarios, y en otros no se aprecia extinción ondulatoria o, si existe, es leve; estos pueden ser cuarzo secundario y se hallan localmente junto con cristales de calcita. Su tamaño es menor de 0,25 mm.

Hay unos cristales muy finos equidimensionales con relieve y colores de interferencia altos que pueden ser circones, pero no es totalmente seguro, porque también podría tratarse de cristales de epidota muy finos.

La calcita se encuentra en cristales anhedrales asociados a la epidota-clinozoisita, al cuarzo y rellenando fracturas muy finas. También aparecen en cristales subhedrales maclados, como relleno de una fractura más gruesa.

En las muestras se pueden encontrar microfracturas rellenas por cuarzo y carbonato. En estas, el cuarzo es anhedral, exhibe extinción ondulatoria leve y los cristales son de mayor tamaño (hasta $0,3 \mathrm{~mm}$ ) que los que conforman la roca.

\section{Diques de andesita}

Las andesitas (IGM1 0908 e IGM37711) exhiben texturas microporfídicas y subofíticas a levemente porfídicas.
La andesita microporfídica (IGM1 0908) consiste de $8 \%$ de cristales (tanto fenocristales como microfenocristales) y $92 \%$ de matriz. Está compuesta por plagioclasa (49\%), hornblenda (41\%), cuarzo (3,5\%), opacos (5,5\%) y titanita (1,0\%). La matriz consta de cristales muy finos de plagioclasa moderadamente alterada y cuarzo en muy poca cantidad (figura 25A).

La plagioclasa está en cristales subhedrales a anhedrales, incoloros. Su tamaño varía entre 0,1 y 0,3 mm; localmente se observan cristales de mayor tamaño que conforman la fracción de microfenocristales junto con hornblenda. Los cristales se encuentran moderadamente alterados a sericita y muestran bordes corroídos. Debido al tamaño y alteración de los cristales no es posible clasificar el tipo de plagioclasa por el método Michel-Lévy.

La hornblenda conforma la fracción de microfenocristales de la roca junto con algunos cristales de plagioclasa. El anfíbol aparece en cristales subhedrales, tabulares, de color café verdoso claro (figura 25A), con leve pleocroísmo a café un poco más oscuro. El tamaño de los cristales fluctúa entre 0,3 y 0,5 mm. Algunos muestran el clivaje típico de anfíbol. Hay cristales maclados, que exhiben alteración a clorita y localmente a epidota.

El cuarzo se halla en cristales anhedrales incoloros. El tamaño de los cristales oscila entre 0,05 y 0,1 mm; esporádicamente aparecen cristales redondeados de mayor tamaño, de hasta 1,3 mm, que pueden corresponder a amígdalas.

Los opacos están presentes en cristales anhedrales de color negro, localmente rojizo, con tamaños de entre 0,2 y 0,5 mm. Se encuentran diseminados en toda la roca (figura 25A).

La titanita aparece en cristales subhedrales de color pardo claro, levemente pleocroicos a pardo más oscuro, con alto relieve.

La roca presenta una alteración propilítica marcada por la presencia de clorita y epidota. Presenta una microvenilla de epidota y localmente lo que parecen ser amígdalas rellenas de cuarzo.

La andesita hornbléndica de textura subofítica (IGM37711) consiste de 55\% de fenocristales, 43\% de matriz y $2 \%$ de amígdalas. Está compuesta por plagioclasa $(88 \%)$, hornblenda (11\%) y opacos + titanita (1\%). La roca está muy alterada a clorita, epidota y calcita.

En esta roca, la plagioclasa se presenta en cristales euhedrales tabulares, principalmente como microfenocristales y microcristales, y en poca cantidad como feno- 

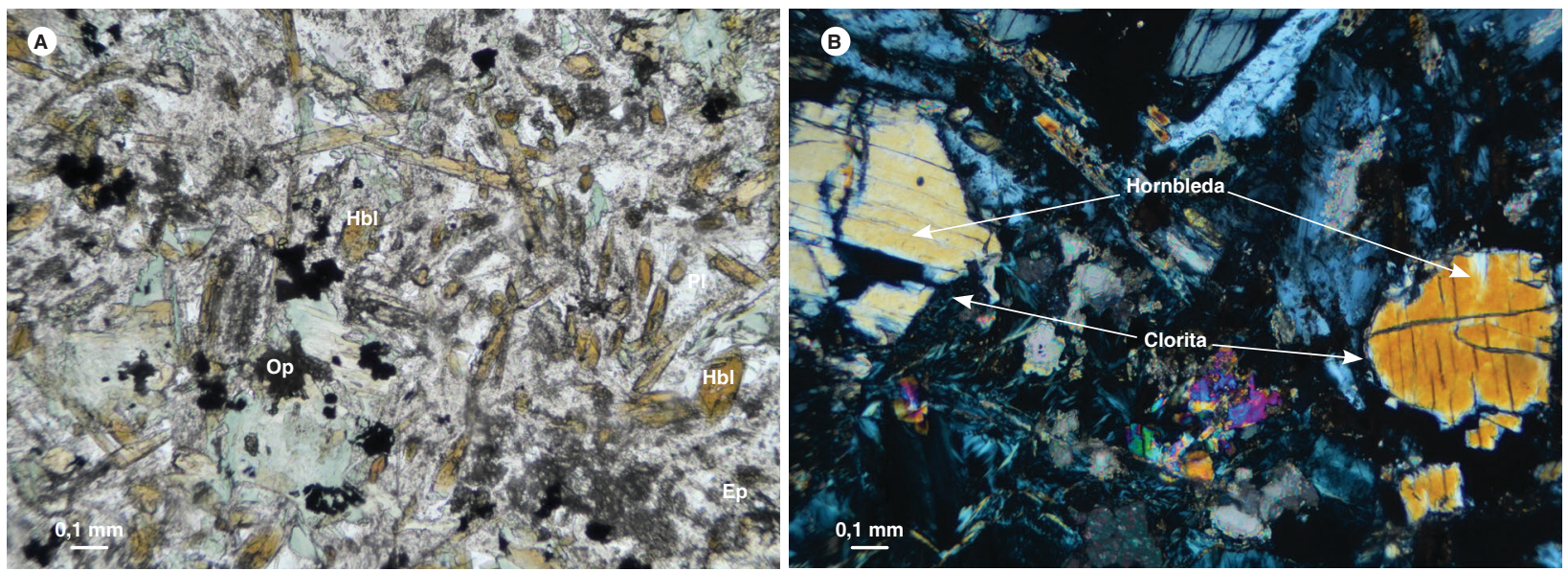

Figura 25. Microfotografías que muestran las características petrográficas de diques de andesita en el Batolito de Mogotes. A) IGM10908. Textura microporfídica con microfenocristales de plagioclasa $(\mathrm{Pl})$, hornblenda $(\mathrm{Hbl})$ en andesita. La roca tiene además opacos (Op) diseminados y epidota (Ep) de alteración. Nícoles paralelos. B) IGM37711. Cristales de hornblenda parcialmente cloritizada en andesita hornbléndica. Nícoles cruzados
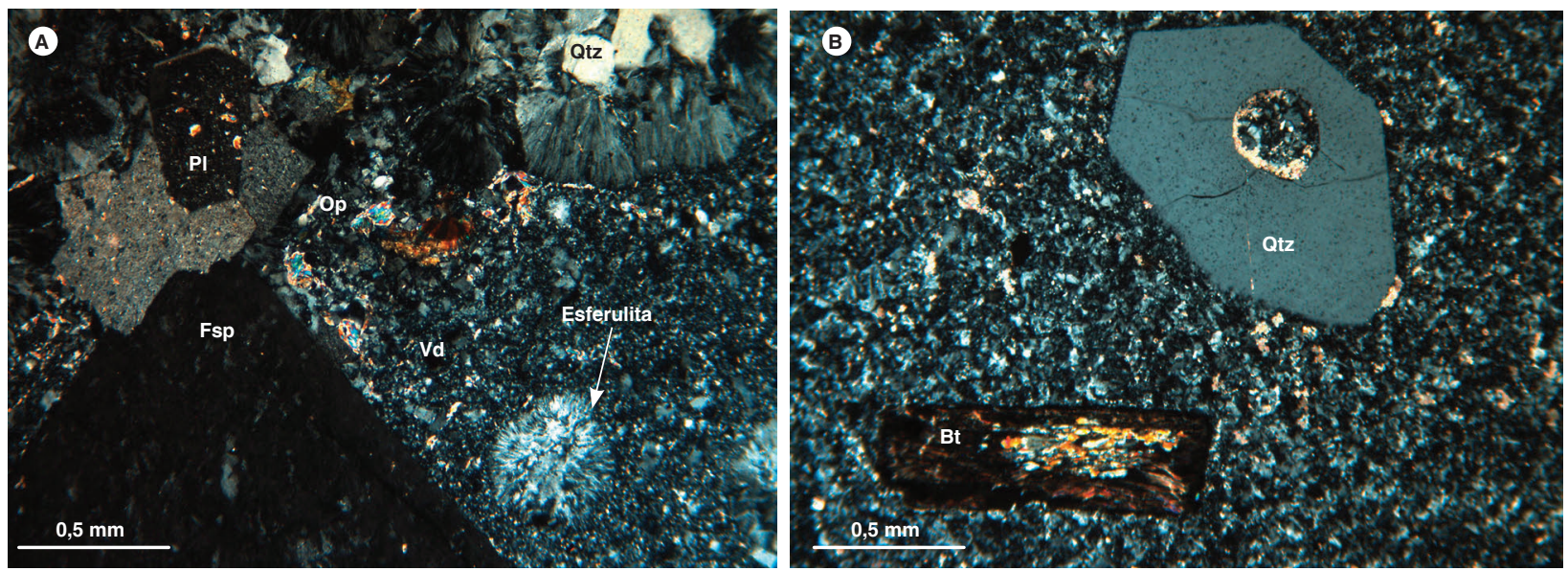

Figura 26. Microfotografías que muestran las características petrográficas de diques de cuarzolatita y riolita en el Batolito de Mogotes. A) IGM900964. Textura porfídica con matriz vítrea (Vd) y microlítica en cuarzolatita. Esferulitas en la matriz por devitrificación. Fenocristales de feldespato potásico (Fsp), plagioclasa (PI) y cuarzo (Qtz). Nícoles cruzados. B) IGM13246. Fenocristal de cuarzo (Qtz) bipiramidal con inclusión de la matriz y fenocristal euhedral de biotita (Bt) en una riolita, con matriz felsítica de grano muy fino. Nícoles cruzados

cristales. Tiene maclas según albita y albita-Carlsbad. Los fenocristales están corroídos por la matriz. No se pudo establecer la composición de la plagioclasa, dada la fuerte saussuritización.

El anfíbol que puede corresponder a hornblenda basáltica se presenta preferentemente en cortes longitudinales, como microfenocristales subhedrales (figura 25B) de color marrón y alterado a clorita en sus bordes.

Las amígdalas son circulares y están rellenas de clorita y calcita; la clorita en ocasiones es plumosa y aparece en láminas con color de interferencia azul Berlín.

\section{Diques de cuarzolatitas y riolitas}

Las cuarzolatitas (IGM 900964 y 900926) presentan como texturas principales la porfídica con matriz microlítica (figura 26) y afanítica microgranular. Otra textura también presente en la matriz es la esferulítica (figura 26A). En la IGM900964, la matriz se compone de vidrio devitrificado con microlitos de feldespato potásico. En la IGM900926 la muestra presenta una fuerte sericitización que impide identificar su composición mineral original, con excepción de las esferulitas.

Las cuarzolatitas consisten aproximadamente de $45 \%$ de cristales y $55 \%$ de matriz. La muestra IGM900964, de textura porfídica y matriz microlítica y esferulíti- 
ca, está compuesta por 37,5\% de plagioclasa, 36,5\% de feldespato potásico, $15 \%$ de cuarzo, $9 \%$ de ferromagnesiano alterado, $2 \%$ de opacos y trazas de allanita; la roca está levemente saussuritizada y sericitizada. La muestra IGM900926, con textura afanítica microgranular y matriz localmente esferulítica, consiste de $55 \%$ de plagioclasa, $39 \%$ de feldespato potásico, $6 \%$ de cuarzo y trazas de opacos y circón; la roca está fuertemente sericitizada.

En la muestra IGM900964, la plagioclasa se presenta en microfenocristales y pocos fenocristales subhedrales (figura 26A) incoloros. Estos están levemente saussuritizados, y algunos, sericitizados. Presentan maclas polisintéticas tipo albita-Carlsbad. Su composición es andesina $\left(\mathrm{An}_{30}\right)$, según estimación por el método Michel-Lévy. En la muestra IGM900926 la plagioclasa está en microfenocristales y microcristales alotriomórficos, alterados casi totalmente a sericita, sin maclas visibles, que pueden estar enmascaradas por la alteración. No fue posible estimar su composición.

En la muestra IGM900964, el feldespato potásico (sanidina) se presenta en mayor porcentaje como microcristales, y en menor proporción como microfenocristales y fenocristales, subhedrales (figura 26A), de incoloros a levemente pardos debido a caolinización. Algunos cristales presentan corrosión en el borde y hacia el centro de los cristales. En la muestra IGM900926, el feldespato potásico aparece principalmente como microcristales, y en menor porcentaje como microfenocristales de textura esferulítica, de incoloros a moteados de color marrón por alteración a caolín, relieve muy bajo y extinción ligeramente radial. El tamaño promedio es menor de 0,5 mm.

En la muestra IGM900964, el cuarzo se presenta principalmente como microfenocristales, y en menor proporción como fenocristales y pocos microcristales. Estos son anhedrales, incoloros, exhiben formas subredondeadas con embahiamientos hacia los bordes y corrosión hacia el centro. Algunos cristales presentan coronas de esferulitas hacia los bordes (figura 26A). En la muestra IGM900926, el cuarzo se presenta como microcristales subordinados, algunos anhedrales, con bordes difusos y otros con un hábito bipiramidal algo irregular, incoloros, con un tamaño promedio de 0,5 mm, y extinción ondulatoria.

En la muestra IGM900964, el ferromagnesiano está completamente alterado a clorita y un poco de epidota. Algunos cristales conservan en cortes basales formas típicas de anfíbol, y otros pudieron corresponder a biotita.
En la muestra IGM900964, la allanita se presenta en microcristales subhedrales, pleocroicos de marrón oscuro a marrón claro, diseminados en la roca.

En ambas muestras, los opacos son escasos. En la IGM900964 son anhedrales y están asociados principalmente al ferromagnesiano alterado, y en la muestra IGM900926 aparecen en microcristales anhedrales de forma irregular alargada y de tonalidad rojiza. Su tamaño está por debajo de 0,1 mm.

En la muestra IGM900926, el circón está presente en cristales euhedrales prismáticos cortos muy finos, menores de 0,01 mm. En la muestra IGM900964 no se observaron circones.

Las riolitas (IGM13246 y 900914) son porfídicas con matriz felsítica de grano muy fino, con un 20\% de cristales y un $80 \%$ de matriz. Están compuestas por cuarzo (8\%), feldespato potásico (4,5\%), plagioclasa (6\%) y biotita $(1,5 \%)$. Pueden presentar glomerocristales, con predominio de feldespatos potásicos sobre la plagioclasa o fragmentos con textura granofídica. Pueden tener fracturas muy finas, menores de 0,1 mm de espesor, rellenas de calcita.

El cuarzo ocurre en cristales subhedrales bipiramidales con inclusiones redondeadas de la matriz y algunas bahías de corrosión en los bordes. Es incoloro y muestra extinción ondulatoria leve. Su tamaño varía desde fenocristales de 1,2 x 1,5 mm y 2 x 2,5 mm hasta microcristales de 0,25 x 0,3 mm.

El feldespato potásico de tipo sanidina se presenta en microfenocristales, microcristales y fenocristales subhedrales tabulares con incipiente desmezcla en pertitas. Exhibe muy leve alteración a arcilla. Su tamaño varía desde 0,75 x 0,75 $\mathrm{mm}$ hasta 1,75 x 2,5 $\mathrm{mm}$.

La plagioclasa se encuentra en microfenocristales, microcristales y fenocristales subhedrales tabulares con macla de albita y albita-Carlsbad, y escasa de periclina. No se hallaron cristales con cortes apropiados para determinar ópticamente su composición. La plagioclasa presenta sericitización moderada e incipiente saussuritización. El tamaño en general es menor de 0,9 x 1,25 mm.

La biotita se presenta en láminas euhedrales y subhedrales, en microfenocristales y microcristales, completamente alterada a clorita y epidota. Puede tener circones incluidos. Su tamaño es menor de 0,9 x 1,2 mm.

El circón se halla en cristales subhedrales redondeados incluidos en biotita alterada y euhedrales prismáticos, con halo pleocroico en la biotita; también en los 
bordes de opacos. Por lo regular su tamaño es menor de 0,06 x 0,1 mm. Algunos cristales de mayor tamaño, clasificados como circones, pueden corresponder a monacita.

El apatito está presente en cristales euhedrales en cortes basales menores de 0,1 mm de diámetro. Se lo encuentra dentro o en los bordes de biotita alterada.

La allanita es escasa y se presenta en microcristales euhedrales diseminados dentro de la matriz. Su tamaño aproximado es de 0,08 x 0,12 mm.

Los opacos se encuentran en cristales anhedrales diseminados en la roca. Su tamaño es menor de 0,25 x 0,3 mm.

\section{Química mineral}

Las secciones delgadas pulidas para análisis de química mineral fueron previamente metalizadas en la Universidad Industrial de Santander. Los minerales representativos de dos muestras del Batolito de Mogotes (IGM900917-JGB470 e IGM900962-TCR376) se analizaron en la microsonda electrónica de la Universidad Nacional de Colombia, sede Bogotá. El equipo usado fue una microsonda JEOL JXA 8230, cuyas condiciones de operación fueron estas: 1 a $10 \mu \mathrm{m}$ de diámetro del haz, tiempo en el pico de $20 \mathrm{~ms}$, intensidad de $20 \mathrm{nA}$ y voltaje de aceleración de $15 \mathrm{kV}$. Los conteos del instrumento son convertidos a porcentajes de óxidos mediante comparaciones con conteos de estándares naturales y sintéticos. Los datos se han tratado mediante la corrección ZAF (Z: número atómico; A: absorción de masas; F: fluorescencia), utilizando el programa de JEOL. La ad- quisición de los datos consistió en obtener imágenes de electrones retrodispersados de los cristales seleccionados para el análisis y en realizar los análisis puntuales.

En la muestra IGM90091 7 se analizaron feldespato potásico, plagioclasa y biotita, mientras que en la muestra IGM900962 se analizaron feldespato potásico, plagioclasa, biotita, magnetita e ilmenita. Los resultados se muestran en las tablas 3 a 7 .

De los feldespatos potásicos analizados en la muestra IGM900917 (JGB-470) no se obtuvieron buenos resultados, al parecer por problemas con la metalización. La plagioclasa se analizó en núcleos y bordes, pero los resultados no fueron buenos en algunos lugares, por lo que se obtuvieron análisis puntales en diferentes cristales, que no permiten interpretar variaciones a lo largo de perfiles núcleo-bordes ni definir la zonación composicional.

\subsection{Feldespato potásico}

El feldespato potásico exhibe micropertitas en filoncillos que se pueden apreciar en las imágenes de las dos muestras analizadas (figura 27). En la muestra IGM900962 (TCR-376) el feldespato potásico corresponde a ortosa pertítica $\left(\mathrm{Or}_{86-95} \mathrm{Ab}_{14-5}\right)$ y a pertita $\left(\mathrm{Or}_{70-74} \mathrm{Ab}_{30-26}\right)$ (tabla 3 , figura 28$)$.

\subsection{Plagioclasa}

La composición de la plagioclasa varía desde andesina $\left(\mathrm{Ab}_{67} \mathrm{An}_{31} \mathrm{Or}_{2}\right)$ hasta oligoclasa-albita $\left(\mathrm{Ab}_{89} \mathrm{An}_{9} \mathrm{Or}_{2}\right)$, según se observa en la tabla 4 y en la figura 28.
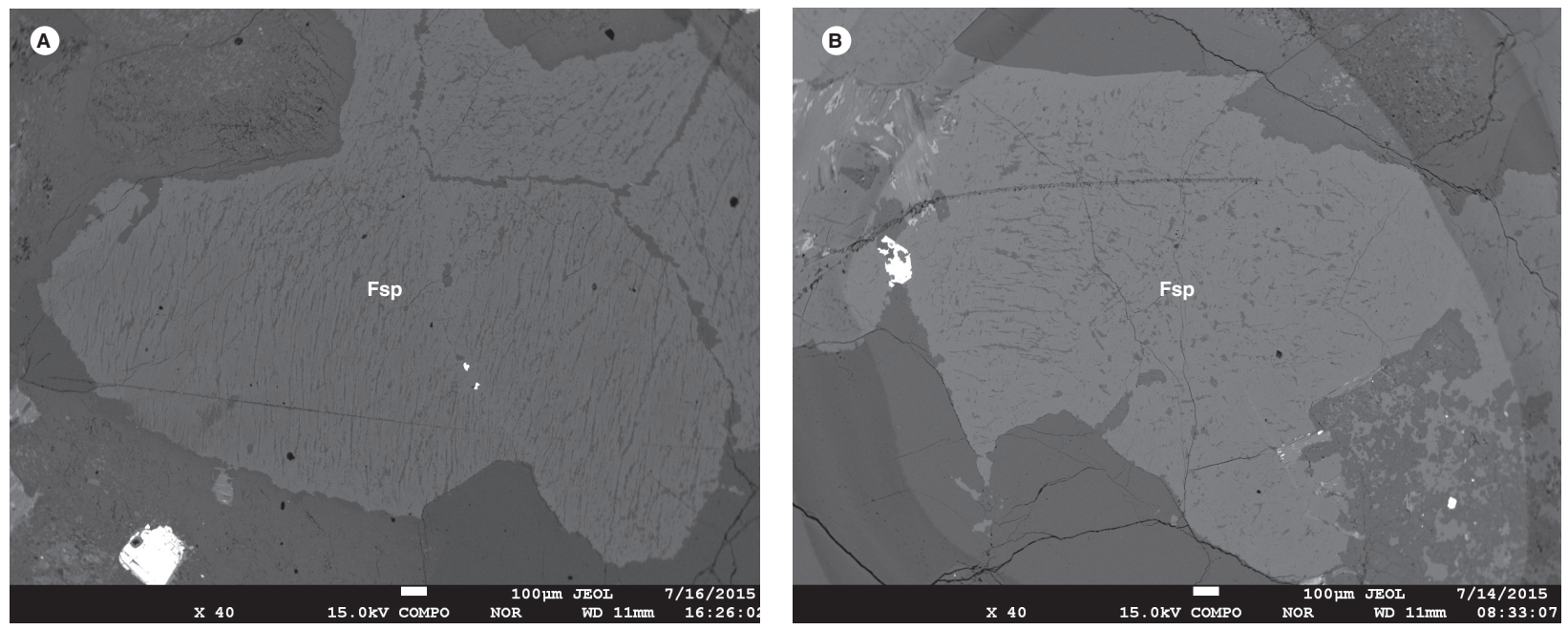

Figura 27. Microfotografía electrónica con imágenes de electrones retrodispersados de cristales de feldespato potásico

A) En muestra TCR-376. Feldespato potásico (Fsp) del campo de análisis C4 en TCR-376. B) En muestra JGB-470. Feldespato potásico con micropertitas en filoncillos, del campo de análisis C3 en JGB-470 


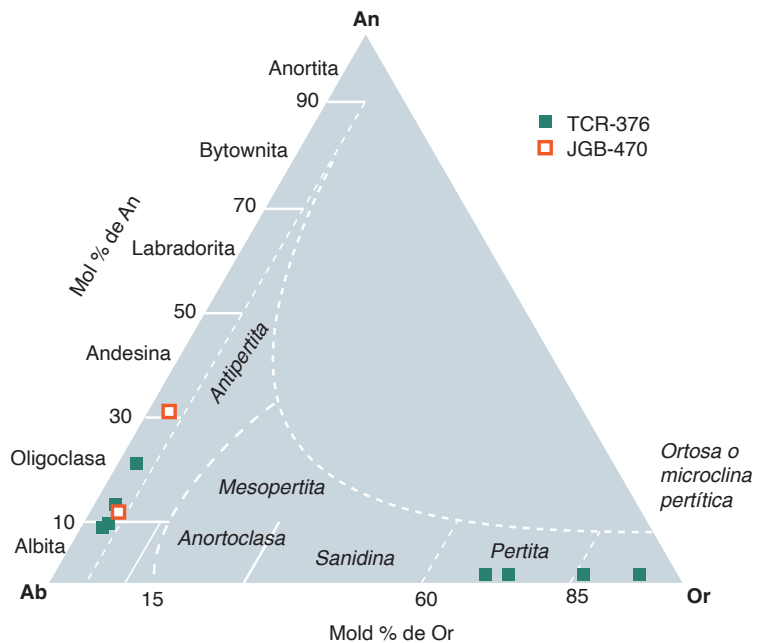

Figura 28. Composición de los feldespatos potásicos y las plagioclasas en monzogranitos del Batolito de Mogotes. Diagrama de Smith y Brown (1988)

Tabla 3. Composición química del feldespato potásico de la muestra IGM900962 (TCR-376) del Batolito de Mogotes

\begin{tabular}{|c|c|c|c|c|}
\hline Punto analizado & TCR-376-C2-Kfs_1 & TCR-376-C2-Kfs_2 & TCR-376-C2-Kfs_3 & TCR-376-C4-Kfs-2 \\
\hline $\mathrm{SiO}_{2}$ & 66,07 & 64,51 & 65,64 & 65,16 \\
\hline $\mathrm{TiO}_{2}$ & 0,01 & 0,01 & 0,00 & 0,00 \\
\hline $\mathrm{Al}_{2} \mathrm{O}_{3}$ & 18,70 & 18,44 & 18,42 & 18,46 \\
\hline $\mathrm{FeO}$ & 0,09 & 0,01 & 0,06 & 0,08 \\
\hline $\mathrm{MgO}$ & 0,00 & 0,00 & 0,00 & 0,00 \\
\hline $\mathrm{CaO}$ & 0,07 & 0,02 & 0,06 & 0,06 \\
\hline $\mathrm{Na}_{2} \mathrm{O}$ & 3,45 & 0,50 & 3,01 & 1,53 \\
\hline $\mathrm{K}_{2} \mathrm{O}$ & 12,29 & 16,01 & 12,96 & 14,64 \\
\hline Total $(\%$ masa $)$ & 100,68 & 99,50 & 100,15 & 99,92 \\
\hline $\mathrm{Si}$ & 11,975 & 11,976 & 11,994 & 11,991 \\
\hline Al & 3,995 & 4,034 & 3,965 & 4,003 \\
\hline $\mathrm{Fe}$ & 0,002 & 0,002 & 0,000 & 0,000 \\
\hline $\mathrm{Ti}$ & 0,009 & 0,001 & 0,006 & 0,008 \\
\hline $\mathrm{Mg}$ & 0 & 0 & 0 & 0 \\
\hline $\mathrm{Na}$ & 1,211 & 0,179 & 1,068 & 0,544 \\
\hline $\mathrm{Ca}$ & 0,013 & 0,005 & 0,011 & 0,011 \\
\hline $\mathrm{K}$ & 2,842 & 3,793 & 3,021 & 3,438 \\
\hline Total (cationes) & 20,047 & 19,990 & 20,065 & 19,995 \\
\hline 0 & 32 & 32 & 32 & 32 \\
\hline z & 15,97 & 16,01 & 15,96 & 15,99 \\
\hline $\mathrm{x}$ & 4,08 & 3,98 & 4,11 & 4,00 \\
\hline Or & 69,90 & 95,37 & 73,69 & 86,09 \\
\hline $\mathrm{Ab}$ & 29,78 & 4,51 & 26,05 & 13,63 \\
\hline An & 0,32 & 0,12 & 0,27 & 0,27 \\
\hline
\end{tabular}


Tabla 4. Composición química de la plagioclasa en las muestras IGM900962 (TCR-376) e IGM900917 (JGB-470) del Batolito de Mogotes

\begin{tabular}{|c|c|c|c|c|c|c|}
\hline Punto analizado & JGB-470-C2-PI-1 & JGB-470-C4-PI-4 & TCR-376-C3-PI1-1 & TCR-376-C3-PI1-3 & TCR-376-C3-PI2-2 & TCR-376-C6-PI-4 \\
\hline $\mathrm{SiO}_{2}$ & 59,49 & 65,09 & 62,86 & 65,87 & 65,12 & 66,13 \\
\hline $\mathrm{TiO}_{2}$ & 0,00 & 0,00 & 0,00 & 0,00 & 0,00 & 0,00 \\
\hline $\mathrm{Al}_{2} \mathrm{O}_{3}$ & 24,25 & 20,95 & 23,68 & 21,51 & 22,05 & 21,26 \\
\hline $\mathrm{FeO}$ & 0,21 & 0,14 & 0,13 & 0,06 & 0,08 & 0,07 \\
\hline $\mathrm{MgO}$ & 0,01 & 0,00 & 0,00 & 0,00 & 0,01 & 0,00 \\
\hline $\mathrm{CaO}$ & 6,79 & 2,48 & 4,66 & 2,21 & 2,92 & 2,00 \\
\hline $\mathrm{Na}_{2} \mathrm{O}$ & 7,99 & 9,69 & 9,31 & 10,65 & 10,28 & 11,10 \\
\hline $\mathrm{K}_{2} \mathrm{O}$ & 0,37 & 0,57 & 0,30 & 0,50 & 0,38 & 0,40 \\
\hline Total (\% masa) & 99,10 & 98,92 & 100,94 & 100,80 & 100,85 & 100,95 \\
\hline $\mathrm{Si}$ & 10,738 & 11,587 & 11,059 & 11,529 & 11,409 & 11,561 \\
\hline $\mathrm{Al}$ & 5,159 & 4,396 & 4,910 & 4,438 & 4,554 & 4,380 \\
\hline $\mathrm{Fe}$ & 0,000 & 0,000 & 0,000 & 0,000 & 0,000 & 0,000 \\
\hline $\mathrm{Ti}$ & 0,021 & 0,014 & 0,013 & 0,005 & 0,008 & 0,007 \\
\hline $\mathrm{Mg}$ & 0,002 & 0,000 & 0,000 & 0,000 & 0,002 & 0,000 \\
\hline $\mathrm{Na}$ & 2,795 & 3,344 & 3,175 & 3,615 & 3,492 & 3,761 \\
\hline $\mathrm{Ca}$ & 1,313 & 0,473 & 0,878 & 0,415 & 0,548 & 0,374 \\
\hline $\mathrm{K}$ & 0,085 & 0,130 & 0,066 & 0,111 & 0,085 & 0,089 \\
\hline Total (cationes) & 20,112 & 19,944 & 20,100 & 20,112 & 20,098 & 20,171 \\
\hline O & 32 & 32 & 32 & 32 & 32 & 32 \\
\hline Z & 15,92 & 16 & 15,98 & 15,97 & 15,97 & 15,95 \\
\hline$x$ & 4,22 & 3,96 & 4,13 & 4,15 & 4,14 & 4,23 \\
\hline $\mathrm{Ab}$ & 66,66 & 84,73 & 77,08 & 87,30 & 84,64 & 89,04 \\
\hline An & 31,32 & 11,98 & 21,31 & 10,03 & 13,30 & 8,86 \\
\hline Or & 2,02 & 3,29 & 1,61 & 2,67 & 2,06 & 2,10 \\
\hline
\end{tabular}

\subsection{Biotita}

Se analizaron láminas de micas pardas en las muestras JGB-470 y TCR-376 (figura 29). Los resultados se presentan en la tabla 5. De acuerdo con el diagrama Si (a.p.f.u.) vs. $\mathrm{Fe} /(\mathrm{Mg}+\mathrm{Fe})$ de Rieder et al. (1 998), se clasifican como biotitas (figura 30A) y genéticamente parecen haberse formado en suites orogénicas calcoalcalinas (figura 30B).
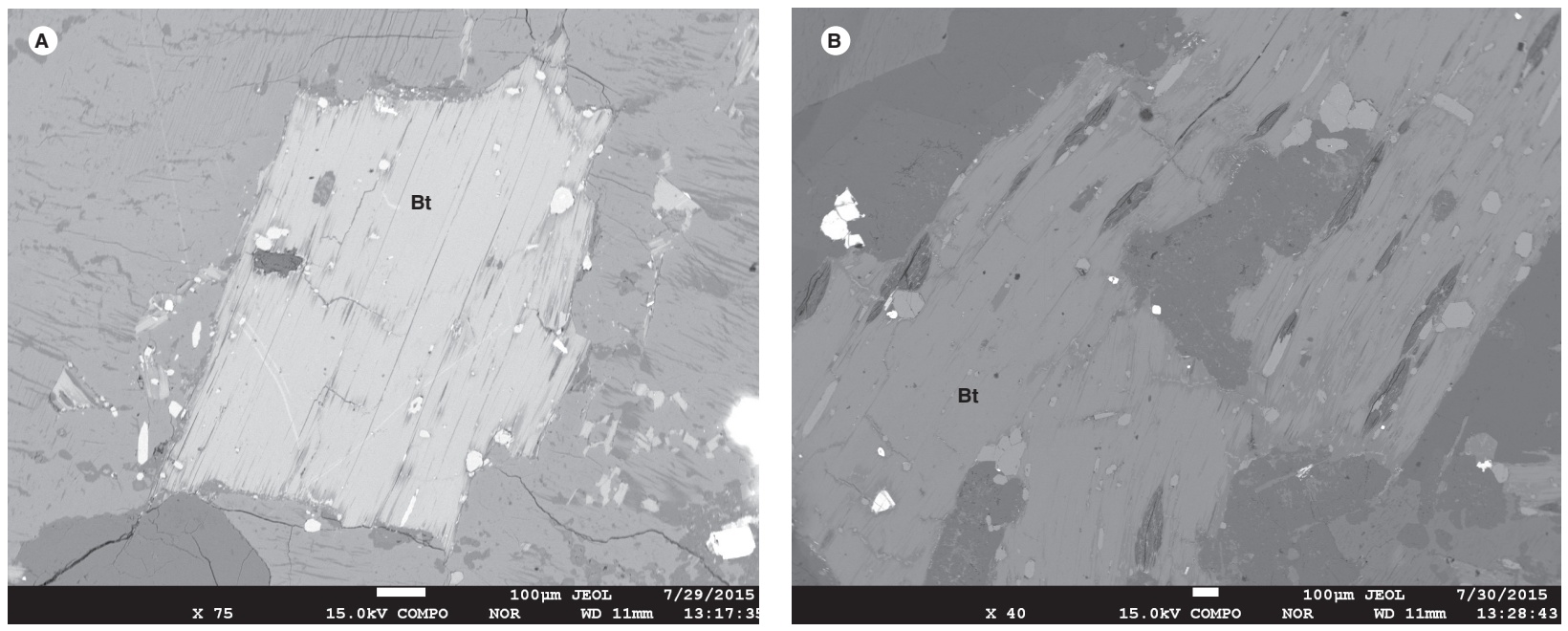

Figura 29. Microfotografías electrónicas que muestran láminas de biotitas analizadas en muestras del Batolito de Mogotes. Imagen de electrones retrodispersados. A) Biotita (Bt) del campo C1 en JGB-470. B) Biotita (Bt) del campo C5 en TCR-376 

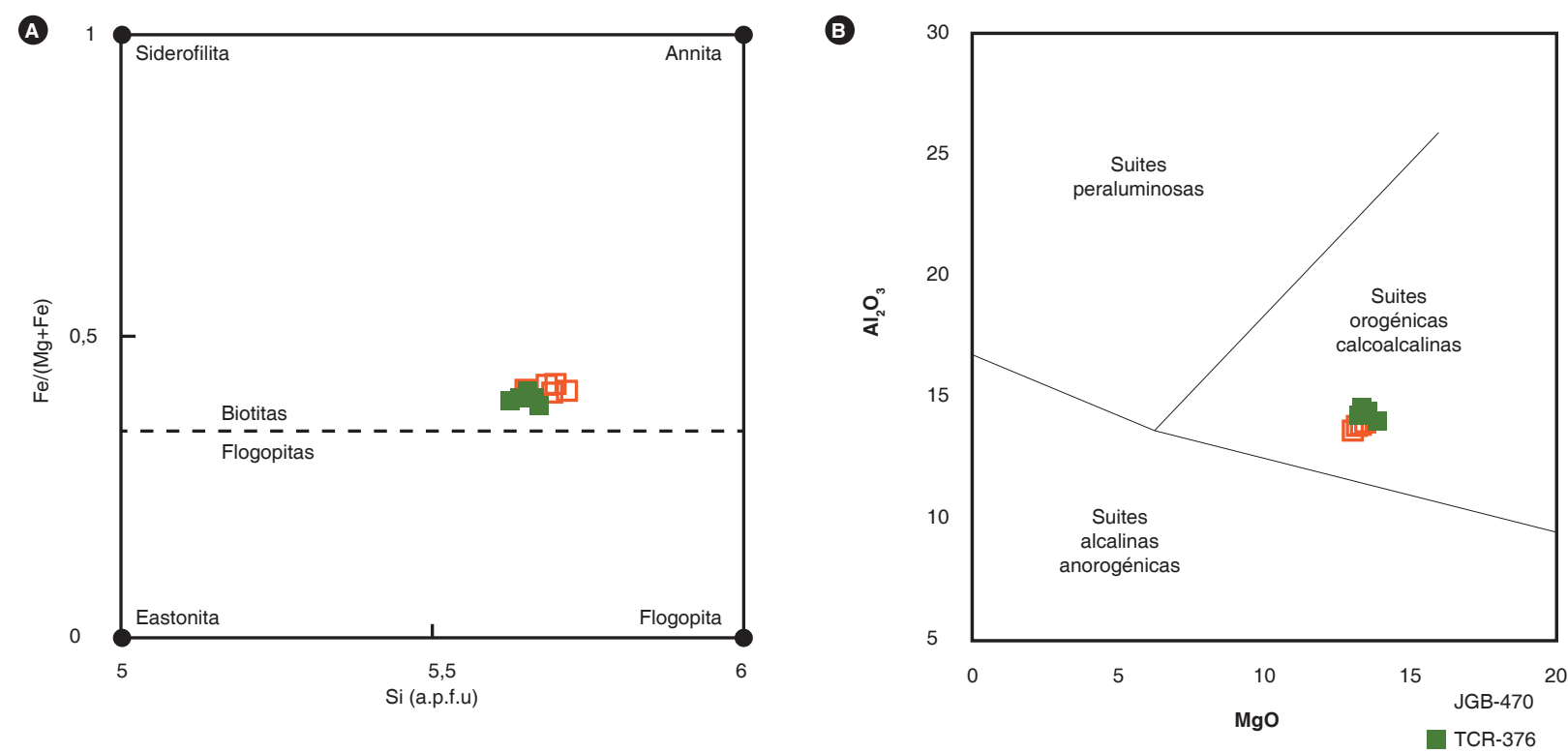

Figura 30. Diagramas de clasificación de micas. A) Diagrama de clasificación de micas según Rieder et al. (1998). B) Composición de las biotitas del Batolito de Mogotes en el diagrama $\mathrm{MgO}$ vs. $\mathrm{Al}_{2} \mathrm{O}_{3}$ de Abdel-Rahman (1994)

Tabla 5. Composición química de la biotita en las muestras IGM900917 (JGB-470) e IGM900962 (TCR-376) del Batolito de Mogotes

\begin{tabular}{|c|c|c|c|c|c|c|c|c|c|c|c|}
\hline & $\begin{array}{c}\text { JGB-470- } \\
\text { C1-Bt-1 }\end{array}$ & $\begin{array}{c}\text { JGB-470- } \\
\text { C1-Bt-2 }\end{array}$ & $\begin{array}{c}\text { JGB-470- } \\
\text { C1-Bt-3 }\end{array}$ & $\begin{array}{c}\text { JGB-470- } \\
\text { C1-Bt-4 }\end{array}$ & $\begin{array}{c}\text { JGB-470- } \\
\text { C1-Bt-5 }\end{array}$ & $\begin{array}{c}\text { JGB-470- } \\
\text { C1-Bt-6 }\end{array}$ & $\begin{array}{c}\text { TCR-376- } \\
\text { C1-Bt-1 }\end{array}$ & $\begin{array}{c}\text { TCR-376- } \\
\text { C1-Bt-2 }\end{array}$ & $\begin{array}{c}\text { TCR-376- } \\
\text { C5-Bt-1 }\end{array}$ & $\begin{array}{c}\text { TCR-376- } \\
\text { C5-Bt-2 }\end{array}$ & $\begin{array}{l}\text { TCR-376- } \\
\text { C5-Bt-3 }\end{array}$ \\
\hline $\mathrm{SiO}_{2}$ & 37,11 & 37,46 & 37,21 & 37,07 & 36,72 & 37,17 & 37,07 & 37,40 & 37,77 & 37,31 & 37,24 \\
\hline $\mathrm{TiO}_{2}$ & 3,17 & 3,20 & 3,21 & 3,03 & 3,35 & 3,09 & 3,27 & 3,24 & 3,52 & 3,39 & 3,35 \\
\hline $\mathrm{Al}_{2} \mathrm{O}_{3}$ & 13,78 & 13,77 & 13,73 & 13,86 & 13,88 & 13,81 & 14,47 & 14,06 & 14,27 & 14,31 & 14,64 \\
\hline $\mathrm{Cr}_{2} \mathrm{O}_{3}$ & 0,00 & 0,00 & 0,00 & 0,00 & 0,00 & 0,00 & 0,00 & 0,00 & 0,00 & 0,00 & 0,00 \\
\hline $\mathrm{FeO}$ & 16,91 & 16,44 & 17,08 & 16,73 & 16,39 & 16,51 & 15,82 & 15,78 & 16,18 & 16,42 & 15,79 \\
\hline $\mathrm{MgO}$ & 12,99 & 13,21 & 13,19 & 13,57 & 13,13 & 13,43 & 13,64 & 13,94 & 13,62 & 13,21 & 13,39 \\
\hline $\mathrm{MnO}$ & 0,38 & 0,45 & 0,42 & 0,46 & 0,50 & 0,44 & 0,54 & 0,47 & 0,53 & 0,52 & 0,55 \\
\hline $\mathrm{CaO}$ & 0,00 & 0,00 & 0,00 & 0,02 & 0,00 & 0,00 & 0,00 & 0,00 & 0,00 & 0,02 & 0,00 \\
\hline $\mathrm{Na}_{2} \mathrm{O}$ & 0,15 & 0,18 & 0,17 & 0,15 & 0,19 & 0,13 & 0,28 & 0,19 & 0,29 & 0,28 & 0,26 \\
\hline $\mathrm{K}_{2} \mathrm{O}$ & 9,45 & 9,57 & 9,37 & 9,44 & 9,41 & 9,37 & 9,44 & 9,42 & 9,55 & 9,46 & 9,28 \\
\hline $\mathrm{F}$ & 0,00 & 0,00 & 0,00 & 0,00 & 0,00 & 0,00 & 0,00 & 0,00 & 0,00 & 0,00 & 0,00 \\
\hline $\mathrm{Cl}$ & 0,00 & 0,00 & 0,00 & 0,00 & 0,00 & 0,00 & 0,00 & 0,00 & 0,00 & 0,00 & 0,00 \\
\hline Total (\% masa) & 93,93 & 94,28 & 94,37 & 94,31 & 93,58 & 93,93 & 94,51 & 94,49 & 95,73 & 94,92 & 94,50 \\
\hline $\mathrm{Si}$ & 5,696 & 5,716 & 5,687 & 5,665 & 5,652 & 5,691 & 5,627 & 5,671 & 5,663 & 5,653 & 5,642 \\
\hline AllV & 2,304 & 2,284 & 2,313 & 2,335 & 2,348 & 2,309 & 2,373 & 2,329 & 2,337 & 2,347 & 2,358 \\
\hline Sum Z & 8,000 & 8,000 & 8,000 & 8,000 & 8,000 & 8,000 & 8,000 & 8,000 & 8,000 & 8,000 & 8,000 \\
\hline AIVI & 0,189 & 0,193 & 0,159 & 0,160 & 0,171 & 0,183 & 0,215 & 0,183 & 0,186 & 0,208 & 0,256 \\
\hline $\mathrm{Ti}$ & 0,366 & 0,367 & 0,369 & 0,348 & 0,388 & 0,356 & 0,373 & 0,369 & 0,397 & 0,387 & 0,382 \\
\hline $\mathrm{Mg}$ & 2,971 & 3,006 & 3,005 & 3,091 & 3,013 & 3,065 & 3,086 & 3,152 & 3,044 & 2,984 & 3,025 \\
\hline $\mathrm{Fe}_{2}+$ & 2,170 & 2,097 & 2,183 & 2,137 & 2,110 & 2,114 & 2,008 & 2,000 & 2,029 & 2,081 & 2,001 \\
\hline $\mathrm{Ni}$ & 0,000 & 0,000 & 0,000 & 0,000 & 0,000 & 0,000 & 0,000 & 0,000 & 0,000 & 0,000 & 0,000 \\
\hline $\mathrm{Mn}$ & 0,049 & 0,058 & 0,054 & 0,059 & 0,066 & 0,057 & 0,069 & 0,060 & 0,067 & 0,066 & 0,070 \\
\hline Sum $Y$ & 5,745 & 5,721 & 5,770 & 5,795 & 5,747 & 5,774 & 5,751 & 5,764 & 5,723 & 5,725 & 5,734 \\
\hline $\mathrm{Ca}$ & 0,000 & 0,000 & 0,000 & 0,003 & 0,000 & 0,000 & 0,000 & 0,000 & 0,000 & 0,003 & 0,000 \\
\hline $\mathrm{Na}$ & 0,043 & 0,053 & 0,050 & 0,043 & 0,057 & 0,037 & 0,082 & 0,057 & 0,084 & 0,082 & 0,076 \\
\hline $\mathrm{K}$ & 1,850 & 1,862 & 1,826 & 1,841 & 1,848 & 1,830 & 1,828 & 1,822 & 1,827 & 1,828 & 1,793 \\
\hline Sum $X$ & 1,894 & 1,915 & 1,876 & 1,886 & 1,905 & 1,867 & 1,910 & 1,879 & 1,911 & 1,913 & 1,869 \\
\hline Total (cationes) & 15,638 & 15,636 & 15,646 & 15,681 & 15,653 & 15,641 & 15,660 & 15,643 & 15,634 & 15,638 & 15,604 \\
\hline $\mathrm{XFe}$ & 0,42 & 0,41 & 0,42 & 0,41 & 0,41 & 0,41 & 0,39 & 0,39 & 0,40 & 0,41 & 0,40 \\
\hline $\mathrm{XMg}$ & 0,58 & 0,59 & 0,58 & 0,59 & 0,59 & 0,59 & 0,61 & 0,61 & 0,60 & 0,59 & 0,60 \\
\hline
\end{tabular}




\subsection{Magnetita}

Cristales de magnetita se analizaron en la muestra TCR376. Los contenidos de $\mathrm{Fe}^{3+}$ y $\mathrm{Fe}^{2+}$ se calcularon usando la fórmula de Droop (1987). La magnetita es de superficie relativamente homogénea y color gris (figura 31). Su composición química (tabla 6) es homogénea con $\mathrm{Fe}^{3+}$ de aproximadamente 11,9 a.p.f.u. y Fe $\mathrm{Fe}^{2+}$ también con 11,9 a.p.f.u., con bajos contenidos de Ti (menos de 0,06 a.p.f.u.), $\mathrm{Al}$ (menos de 0,14 a.p.f.u.), $\mathrm{Cr}$ (menos de 0,016 a.p.f.u.) y Mn (menos de 0,041 a.p.f.u.).

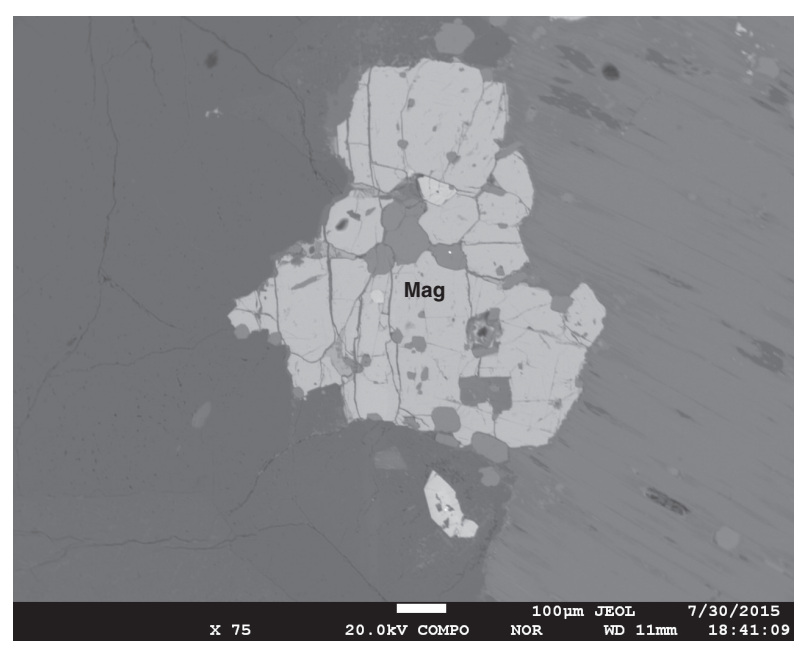

Figura 31. Microfotografía en la que se muestras cristal de magnetita (Mag) analizado en la muestra TCR-376. Imagen de electrones retrodispersados

Tabla 6. Resultados de química mineral de magnetita en la muestra TCR-376

\begin{tabular}{|c|c|c|c|c|c|}
\hline Punto analizado & TCR-376-C1-Mt-1 & TCR-376-C1-Mt-2 & TCR-376-C1-Mt-3 & TCR-376-C7-Mt-1 & TCR-376-C7-Mt-2 \\
\hline $\mathrm{SiO}_{2}$ & 0,005 & ND & ND & ND & ND \\
\hline $\mathrm{TiO}_{2}$ & 0,269 & ND & 0,005 & 0,106 & 0,0200 \\
\hline $\mathrm{Al}_{2} \mathrm{O}_{3}$ & 0,398 & 0,032 & ND & 0,089 & 0,0170 \\
\hline $\mathrm{Cr}_{2} \mathrm{O}_{3}$ & 0,045 & 0,053 & 0,068 & 0,045 & 0,0210 \\
\hline $\mathrm{FeO}$ & 95,896 & 97,823 & 97,434 & 97,467 & 98,2790 \\
\hline $\mathrm{MnO}$ & 0,164 & 0,052 & 0,055 & 0,036 & 0,0510 \\
\hline $\mathrm{MgO}$ & ND & ND & ND & 0,024 & ND \\
\hline Total (\% masa) & 96,777 & 97,96 & 97,562 & 97,767 & 98,388 \\
\hline $\mathrm{Si}$ & 0,001 & ND & ND & ND & ND \\
\hline $\mathrm{Ti}$ & 0,060 & ND & 0,001 & 0,023 & 0,004 \\
\hline $\mathrm{Al}$ & 0,139 & 0,011 & ND & 0,031 & 0,006 \\
\hline $\mathrm{Cr}$ & 0,011 & 0,012 & 0,016 & 0,010 & 0,005 \\
\hline $\mathrm{Fe}^{3+}$ & 11,863 & 11,988 & 11,991 & 11,956 & 11,990 \\
\hline $\mathrm{Fe}^{2+}$ & 11,885 & 11,975 & 11,978 & 11,960 & 11,982 \\
\hline $\mathrm{Mg}$ & ND & ND & ND & 0,010 & ND \\
\hline $\mathrm{Mn}$ & 0,041 & 0,013 & 0,014 & 0,009 & 0,013 \\
\hline Total (cationes) & 24,000 & 24,000 & 24,000 & 24,000 & 24,000 \\
\hline
\end{tabular}

ND: no detectado

\subsection{IImenita}

La ilmenita también se analizó en la muestra TCR-376. Tiene la superficie más porosa que la magnetita y parece tener alteración, aunque puede presentar también finas lamelas de exsolución. Es de color gris con tonalidad rosa (figura 32). Los resultados se presentan en la tabla 7. Los contenidos de $\mathrm{Fe}^{3+}$ y $\mathrm{Fe}^{2}+$ se calcularon usando la fórmula de Droop (1987).
La ilmenita de esta roca se caracteriza por tener entre 49,2 y 53,9\% de $\mathrm{TiO}_{2}$ (1,86-2,04 a.p.f.u. de Ti), entre 34,5 y $40 \%$ de FeO total (entre 1,40 y 1,48 a.p.f.u. de Fe ${ }^{2+}$ y menos de 0,28 a.p.f.u. o nada de $\mathrm{Fe}^{3+}$ ) y presenta entre 10,7 y 1 1,9\% de $\mathrm{MnO}$ (0,45-0,51 a.p.f.u. de Mn), que es una cantidad significativa e indica sustitución del Fe por el Mn. Se puede clasificar como ilmenita con manganeso. 


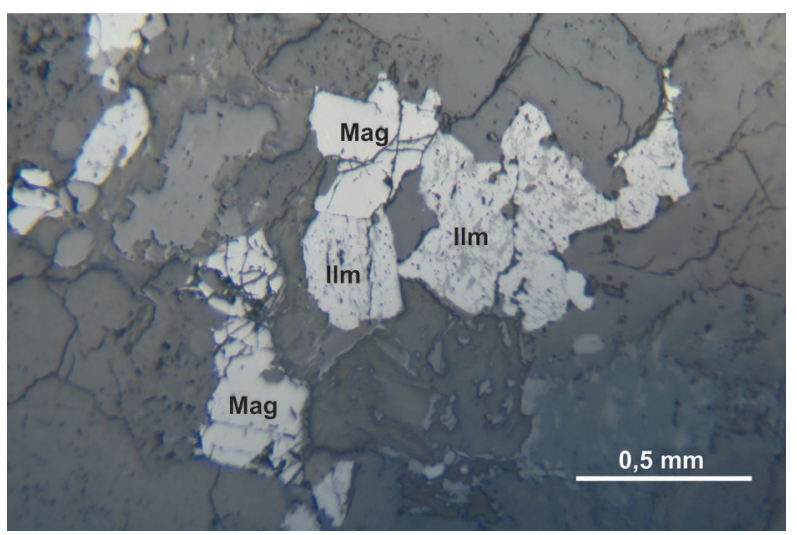

Figura 32. Microfotografía tomada con luz reflejada en microscopio petrográfico, donde se observan cristales de ilmenita (IIm) y magnetita (Mag) analizados en la muestra TCR-376

Tabla 7. Composición química de la ilmenita en la muestra TCR-376

\begin{tabular}{cccc}
\hline Punto analizado & TCR-376-C7-IIm-1 & TCR-376-C7-IIm-2 & TCR-376-C7-IIm-3 \\
\hline $\mathrm{SiO}_{2}$ & 0,018 & $\mathrm{ND}$ & 0,011 \\
\hline $\mathrm{TiO}_{2}$ & 49,202 & 53,997 & 53,152 \\
\hline $\mathrm{Al}_{2} \mathrm{O}_{3}$ & 0,007 & 0,005 & $\mathrm{ND}$ \\
\hline $\mathrm{Cr}_{2} \mathrm{O}_{3}$ & $\mathrm{ND}$ & 0,009 & $\mathrm{ND}$ \\
\hline $\mathrm{V}_{2} \mathrm{O}_{3}$ & 0,329 & 0,325 & 0,340 \\
\hline $\mathrm{FeO}$ & 40,010 & 34,569 & 34,846 \\
\hline $\mathrm{MnO}$ & 10,721 & 11,921 & 11,449 \\
\hline $\mathrm{MgO}$ & 0,019 & 0,027 & 0,050 \\
\hline $\mathrm{CaO}$ & $\mathrm{ND}$ & $\mathrm{ND}$ & $\mathrm{ND}$ \\
\hline $\mathrm{Total}$ & 100,306 & 100,853 & 99,848 \\
\hline & $\mathrm{Cationes} \mathrm{calculados} \mathrm{a} \mathrm{partir} \mathrm{de} 6(\mathbf{0})$ & \\
\hline $\mathrm{Si}$ & 0,001 & 0,000 & 0,001 \\
\hline $\mathrm{Ti}$ & 1,860 & 2,039 & 2,027 \\
\hline $\mathrm{Cr}$ & 0,000 & 0,000 & 0,000 \\
\hline $\mathrm{Al}$ & 0,000 & 0,000 & 0,000 \\
\hline $\mathrm{Fe}{ }^{3+}$ & 0,278 & 0,000 & 0,000 \\
\hline $\mathrm{Fe}{ }^{2+}$ & 1,403 & 1,451 & 1,477 \\
\hline $\mathrm{Mn}$ & 0,456 & 0,507 & 0,492 \\
\hline $\mathrm{Mg}$ & 0,001 & 0,002 & 0,004 \\
\hline $\mathrm{Ca}$ & 0,000 & 0,000 & 0,000 \\
\hline $\mathrm{V}$ & 0,013 & 0,013 & 0,014 \\
\hline $\mathrm{Total}$ & 4,000 & 4,000 & 4,000 \\
& & &
\end{tabular}

\section{Geoquímica}

Los análisis geoquímicos se hicieron en el laboratorio del Servicio Geológico Colombiano, en Bogotá. Los de elementos mayores y menores se realizaron con un espectrómetro de fluorescencia de rayos X, FRX, Panalytical Axios Mineral para análisis elemental, configurado con software especializado para materiales geológicos. La cuantificación de los óxidos mayores se realizó en muestra fundida con metaborato y tetraborato de litio, y la cuantificación de elementos menores se llevó a cabo en muestra prensada. Para el análisis de elementos traza se usó un espectrómetro de masas con plasma inductivamente acoplado, ICP-MS, Perkin Elmer Nexion. La disolución de la muestra se hizo mediante ataque por pasos utilizando ácidos inorgánicos fuertes $\left(\mathrm{HF}, \mathrm{HNO}_{3}\right.$, $\mathrm{HClO}_{4}$ y HCl), en sistema abierto, empleando distintas rampas de temperatura y tiempos de calentamiento.

Los valores de óxidos mayores se presentan en porcentaje en peso (wt\%), mientras que los elementos traza se presentan en partes por millón (ppm). Gran parte de los diagramas geoquímicos se generaron con el uso del GCDKit version 4.0 (Janoušek et al., 2006).

Se llevaron a cabo los análisis químicos en trece muestras de rocas plutónicas correspondientes a monzogranitos, granodioritas y cuarzomonzodioritas del cuerpo principal y se retomaron tres análisis de Van der Lelij (2013) correspondientes a las muestras 10VDL28, 10VDL31 y 10VDL32. De los cuerpos menores y diques se analizaron 12 muestras. Los valores de óxidos mayores se presentan en porcentaje en peso (wt\%), mientras que los elementos traza se presentan en partes por millón (ppm).

\section{1. Óxidos mayores, elementos traza y de las tierras raras}

Los resultados de elementos mayores se presentan en la tabla 8. Los resultados de elementos traza y de las tierras raras de las rocas graníticas se presentan en la tabla 9, y los de cuerpos menores y diques, en la tabla 10 . 
Tabla 8. Resultados de óxidos mayores del Batolito de Mogotes

\begin{tabular}{|c|c|c|c|c|c|c|c|c|c|c|c|}
\hline IGM & $\mathrm{SiO}_{2}$ & $\mathrm{TiO}_{2}$ & $\mathrm{Al}_{2} \mathrm{O}_{3}$ & $\mathrm{Fe}_{2} \mathrm{O}_{3}$ & $\mathrm{MgO}$ & $\mathrm{CaO}$ & $\mathrm{Na}_{2} \mathrm{O}$ & $\mathrm{K}_{2} \mathrm{O}$ & $\mathrm{P}_{2} \mathrm{O}_{5}$ & $\mathrm{MnO}$ & LOI \\
\hline \multicolumn{12}{|c|}{ Rocas graníticas } \\
\hline 900944 & 76,17 & 0,25 & 12,85 & 1,38 & 0,38 & 0,13 & 2,75 & 4,67 & 0,035 & 0,57 & 1,23 \\
\hline 900887 & 74,56 & 0,01 & 14,63 & 1,20 & 0,04 & 0,71 & 3,36 & 4,48 & & 0,04 & 0,15 \\
\hline 900927 & 74,56 & 0,16 & 14,32 & 1,06 & 0,22 & 1,02 & 2,48 & 4,84 & & 0,04 & 0,69 \\
\hline 900965 & 73,75 & 0,28 & 13,79 & 1,68 & 0,30 & 1,34 & 2,84 & 5,15 & 0,057 & 0,44 & 0,67 \\
\hline 900869 & 73,36 & 0,29 & 13,99 & 1,63 & 0,46 & 1,48 & 3,47 & 4,42 & 0,076 & 0,66 & 0,66 \\
\hline 900943 & 73,25 & 0,29 & 14,25 & 1,64 & 0,28 & 1,08 & 2,45 & 5,25 & 0,059 & 0,58 & 1,30 \\
\hline 900966 & 72,51 & 0,34 & 14,21 & 2,01 & 0,88 & 0,67 & 3,13 & 4,96 & 0,092 & 0,49 & 1,06 \\
\hline 900874 & 71,62 & 0,65 & 15,59 & 1,71 & 0,06 & 0,35 & 3,56 & 4,89 & & 0,02 & 0,58 \\
\hline 900962 & 70,14 & 0,39 & 15,27 & 2,23 & 0,74 & 2,17 & 3,57 & 4,06 & 0,130 & 0,55 & 1,03 \\
\hline 10VDL32* & 69,61 & 0,43 & 15,33 & 2,67 & 0,92 & 2,62 & 3,46 & 3,97 & 0,16 & 0,07 & 0,84 \\
\hline 10VDL31* & 68,26 & 0,5 & 15,01 & 3,31 & 1,48 & 2,74 & 3,11 & 3,71 & 0,17 & 0,07 & 1,38 \\
\hline 900917 & 67,21 & 0,72 & 16,32 & 3,49 & 1,70 & 1,81 & 3,02 & 3,50 & & 0,07 & 1,20 \\
\hline 10VDL28* & 64,23 & 0,61 & 15,36 & 4,04 & 1,91 & 3,26 & 3 & 4,05 & 0,2 & 0,08 & 3,29 \\
\hline 900900 & 61,59 & 0,46 & 18,23 & 4,31 & 2,95 & 2,74 & 3,55 & 4,22 & & 0,09 & 1,07 \\
\hline 900903 & 59,23 & 0,67 & 17,28 & 5,89 & 4,11 & 2,10 & 4,53 & 2,45 & & 0,10 & 2,24 \\
\hline 900902 & 59,21 & 0,52 & 19,51 & 4,49 & 3,23 & 3,51 & 4,13 & 3,52 & & 0,09 & 1,00 \\
\hline \multicolumn{12}{|c|}{ Cuerpos menores } \\
\hline 900942 & 77,24 & 0,14 & 12,64 & 0,62 & $<0,10$ & 0,24 & 3,34 & 5,14 & $<0,024$ & 0,29 & 0,55 \\
\hline 900875 & 74,10 & 0,11 & 14,32 & 1,19 & 0,02 & 0,78 & 3,76 & 4,72 & & 0,04 & 0,12 \\
\hline \multicolumn{12}{|c|}{ Rocas de dique } \\
\hline 900868 & 53,12 & 1,19 & 16,95 & 8,03 & 5,87 & 8,28 & 0,09 & 0,65 & & 0,15 & 4,79 \\
\hline 900915 & 77,23 & 0,02 & 12,64 & 0,85 & 0,02 & 0,53 & 3,38 & 4,38 & & 0,04 & 0,08 \\
\hline 900963 & 77,52 & 0,10 & 12,68 & 0,55 & $<0,10$ & 0,57 & 3,61 & 4,77 & $<0,024$ & 399 & 0,22 \\
\hline 900889 & 74,98 & 0,23 & 14,10 & 1,07 & 0,02 & 0,55 & 3,68 & 4,40 & & 0,03 & 0,21 \\
\hline 900888 & 76,44 & 0,30 & 13,56 & 0,87 & 0,01 & 0,39 & 3,32 & 3,81 & & 0,04 & 0,17 \\
\hline 900901 & 67,39 & 0,04 & 17,42 & 1,00 & 0,07 & 2,52 & 4,20 & 5,43 & & 0,02 & 0,08 \\
\hline 900904 & 74,56 & 0,04 & 15,1 & 0,37 & 0,01 & 0,7 & 4,42 & 4,26 & 0,024 & 203 & 0,55 \\
\hline 900914 & 76,52 & 0,06 & 12,61 & 1,23 & 0,07 & 0,65 & 3,37 & 4,52 & & 0,02 & 0,14 \\
\hline 900964 & 73,75 & 0,28 & 13,79 & 1,51 & 0,46 & 1,19 & 3,54 & 4,38 & 0,077 & 452 & 0,81 \\
\hline 900926 & 82,47 & 0,06 & 11,36 & 0,65 & $<0,10$ & $<0,10$ & 0,10 & 3,36 & $<0,024$ & 407 & 1,78 \\
\hline
\end{tabular}

Las concentraciones de óxidos son presentadas en porcentaje en peso

LOI: pérdida al fuego. * Van der Lelij (2013)

Tabla 9. Resultados de elementos traza y tierras raras en rocas del cuerpo principal del Batolito de Mogotes

\begin{tabular}{|c|c|c|c|c|c|c|c|c|c|c|c|c|c|c|c|c|}
\hline IGM & 900944 & 900887 & 900927 & 900965 & 900869 & 900943 & 900966 & 900874 & 900962 & 10VDL32* & 10VDL31* & 900917 & 10VDL28* & 900900 & 900903 & 900902 \\
\hline $\mathrm{Li}$ & 23 & 8,0 & 31 & 23 & 6,6 & 20 & 52 & 29 & 17 & & & 33 & & 30 & 32 & 23 \\
\hline $\mathrm{Be}$ & 3,6 & 3,2 & 1,9 & 2,9 & 3,0 & 3,7 & 4,1 & 2,7 & 4,2 & 3,92 & 4,62 & 3,9 & 2,39 & 3,5 & 4,0 & 2,8 \\
\hline Sc & 6,2 & 4,2 & 6,5 & 7,1 & 4,9 & 6,8 & 12 & 6,0 & 7,5 & 6,04 & 9,6 & 12 & 10,11 & 16 & 20 & 14 \\
\hline v & 10 & 4,3 & 13 & 16 & 16 & 16 & 23 & 24 & 26 & 37 & 56 & 50 & 80 & 81 & 103 & 78 \\
\hline $\mathrm{Cr}$ & 2,0 & 1,0 & 5,1 & 6,2 & 1,2 & 4,6 & 3,6 & 1,4 & 6,3 & 7 & 36 & 32 & 42 & 42 & 49 & 35 \\
\hline Co & 11 & 12 & 15 & 20 & 11 & 16 & 19 & 15 & 19 & 4,28 & 6,77 & 21 & 9,98 & 21 & 24 & 20 \\
\hline $\mathrm{Ni}$ & 12 & 0,53 & 3,7 & 3,960 & 2,9 & 3,8 & 3,606 & 4,7 & 5,468 & 6,91 & 25,31 & 20 & 28,12 & 39 & 35 & 27 \\
\hline $\mathrm{Cu}$ & 5,5 & 5,0 & 5,0 & 3,2 & 4,7 & 4,9 & 3,6 & 5,8 & 4,8 & 14,99 & 7,32 & 13 & 11,62 & 23 & 34 & 16 \\
\hline $\mathrm{Zn}$ & 31 & 10 & 24 & 30 & 26 & 28 & 45 & 56 & 36 & 39 & 55 & 50 & 63 & 64 & 83 & 60 \\
\hline Ga & 17 & 14 & 14 & 20 & 17 & 20 & 18 & 19 & 19 & 18,01 & 19,16 & 20 & 19,16 & 20 & 20 & 21 \\
\hline As & 2,3 & 1,7 & 1,2 & 2,7 & 1,6 & 2,7 & 2,2 & 1,7 & 2,1 & 6,1 & 2,93 & 1,8 & 1,95 & 2,7 & 3,7 & 2,5 \\
\hline $\mathbf{R b}$ & 166 & 201 & 173 & 290 & 160 & 352 & 254 & 147 & 177 & 128,38 & 113,94 & 160 & 139,49 & 114 & 91 & 135 \\
\hline $\mathrm{Sr}$ & 104 & 36 & 157 & 121 & 181 & 190 & 173 & 268 & 420 & 409,77 & 429,31 & 407 & 429,16 & 493 & 635 & 540 \\
\hline In & 0,023 & 0,014 & 0,022 & 0,022 & 0,018 & 0,015 & 0,036 & 0,029 & 0,017 & & & 0,047 & & 0,053 & 0,066 & 0,051 \\
\hline Cs & 1,6 & 1,5 & 2,6 & 2,8 & 1,6 & 3,7 & 3,7 & 2,0 & 1,3 & 1,76 & 1,18 & 2,0 & 0,84 & 1,3 & 1,6 & 1,6 \\
\hline $\mathrm{Ba}$ & 1257 & 358 & 1093 & 1119 & 1082 & 1464 & 1058 & 1178 & 1331 & 985,71 & 702,57 & 1093 & 935,95 & 1222 & 874 & 1212 \\
\hline $\mathrm{TI}$ & 1,0 & 1,2 & 1,1 & 1,4 & 0,95 & 2,6 & 1,1 & 0,92 & 0,85 & & & 1,0 & & 0,63 & 0,51 & 0,78 \\
\hline
\end{tabular}




\begin{tabular}{|c|c|c|c|c|c|c|c|c|c|c|c|c|c|c|c|c|}
\hline IGM & 900944 & 900887 & 900927 & 900965 & 900869 & 900943 & 900966 & 900874 & 900962 & 10VDL32* & 10VDL31* & 900917 & 10VDL28* & 900900 & 900903 & 900902 \\
\hline $\mathrm{Pb}$ & 18 & 23 & 16 & 22 & 19 & 19 & 17 & 13 & 19 & 14,98 & 14,47 & 22 & 12,78 & 27 & 9,3 & 18 \\
\hline $\mathrm{Bi}$ & 0,06 & 0,09 & 0,06 & $<0,05$ & 1,5 & $<0,05$ & 0,04 & 0,13 & $<0,05$ & 0,04 & 0,07 & 0,09 & 0,05 & 0,06 & 0,07 & 0,06 \\
\hline Th & 19 & 20 & 20 & 34 & 19 & 22 & 22 & 15 & 19 & 18,5 & 22,61 & 23 & 18,31 & 18 & 18 & 24 \\
\hline U & 3,4 & 3,8 & 3,6 & 2,4 & 4,0 & 2,0 & 5,1 & 2,4 & 2,8 & 3,24 & 6,08 & 3,9 & 2,93 & 3,2 & 2,7 & 4,5 \\
\hline $\mathrm{Zr}$ & 119 & 57 & 99 & 183 & 146 & 164 & 166 & 219 & 186 & 211,24 & 196,29 & 160 & 216,33 & 190 & 242 & 186 \\
\hline $\mathrm{Nb}$ & 20 & 20 & 11 & 13 & 17 & 15 & 18 & 15 & 18 & 13,43 & 14,11 & 12 & 11,52 & 12 & 15 & 11 \\
\hline w & 36 & 48 & 46 & 72 & 42 & 45 & 58 & 50 & 50 & 0,63 & 0,27 & 42 & 0,39 & 30 & 21 & 32 \\
\hline La & 58 & 19 & 27 & 78 & 40 & 76 & 58 & 47 & 59 & 47,44 & 59,62 & 59 & 60,5 & 55 & 62 & 56 \\
\hline $\mathrm{Ce}$ & 91 & 43 & 46 & 128 & 71 & 112 & 96 & 81 & 98 & 81,08 & 105,7 & 111 & 104,75 & 106 & 132 & 107 \\
\hline $\mathrm{Pr}$ & 13 & 5,4 & 4,4 & 14 & 7,4 & 16 & 12 & 9,0 & 11 & 8,27 & 11,08 & 13 & 10,79 & 13 & 16 & 13 \\
\hline Nd & 42 & 18 & 11 & 44 & 23 & 52 & 39 & 28 & 36 & 29,69 & 40,31 & 36 & 39,27 & 46 & 53 & 42 \\
\hline $\mathrm{Sm}$ & 7,8 & 4,2 & 2,1 & 9,3 & 3,9 & 9,6 & 7,0 & 4,8 & 6,5 & 4,56 & 7,16 & 6,3 & 6,01 & 7,3 & 9,7 & 7,2 \\
\hline $\mathrm{Eu}$ & 1,5 & 0,49 & 0,85 & 1,4 & 0,91 & 1,9 & 1,4 & 1,1 & 1,6 & 1,1 & 1,37 & 1,4 & 1,37 & 1,4 & 1,6 & 1,5 \\
\hline Gd & 5,9 & 2,9 & 1,9 & 7,1 & 3,1 & 8,1 & 5,3 & 3,8 & 4,7 & 3,15 & 5,3 & 4,7 & 4,31 & 5,2 & 6,6 & 5,1 \\
\hline $\mathrm{Tb}$ & 1,3 & 0,67 & 0,34 & 1,4 & 0,56 & 2,0 & 1,1 & 0,63 & 0,92 & 0,44 & 0,79 & 0,75 & 0,61 & 0,90 & 1,1 & 0,90 \\
\hline Dy & 5,9 & 3,8 & 1,7 & 6,4 & 3,0 & 10 & 4,8 & 3,4 & 4,1 & 2,88 & 4,72 & 3,2 & 3,49 & 4,3 & 5,6 & 4,1 \\
\hline Ho & 1,2 & 0,78 & 0,36 & 1,2 & 0,62 & 2,0 & 0,99 & 0,63 & 0,79 & 0,55 & 0,96 & 0,64 & 0,72 & 0,79 & 1,1 & 0,80 \\
\hline Er & 3,6 & 2,5 & 1,2 & 3,7 & 2,1 & 5,8 & 3,1 & 2,0 & 2,5 & 1,62 & 2,61 & 2,0 & 1,91 & 2,5 & 3,3 & 2,5 \\
\hline $\mathrm{Tm}$ & 0,50 & 0,39 & 0,18 & 0,45 & 0,30 & 0,79 & 0,41 & 0,27 & 0,33 & 0,23 & 0,38 & 0,26 & 0,27 & 0,32 & 0,40 & 0,31 \\
\hline $\mathrm{Yb}$ & 3,3 & 2,8 & 1,3 & 2,8 & 2,1 & 5,2 & 2,9 & 1,8 & 2,2 & 1,77 & 2,74 & 1,7 & 1,89 & 2,0 & 2,6 & 2,0 \\
\hline Lu & 0,48 & 0,43 & 0,22 & 0,41 & 0,32 & 0,73 & 0,43 & 0,27 & 0,32 & 0,29 & 0,38 & 0,27 & 0,3 & 0,29 & 0,37 & 0,30 \\
\hline
\end{tabular}

La abundancia de elementos traza se reporta en partes por millón (ppm).

* Van der Lelij (2013); Van der Lelij (2013)

Tabla 10. Resultados de elementos traza y tierras raras correspondientes a cuerpos menores y rocas de dique

\begin{tabular}{|c|c|c|c|c|c|c|c|c|c|c|c|c|}
\hline IGM & 900942 & 900875 & 900868 & 900915 & 900963 & 900889 & 900888 & 900901 & 900904 & 900914 & 900964 & 900926 \\
\hline $\mathrm{Li}$ & 7,0 & 38 & 30 & 12 & 5,2 & 4,2 & 8,7 & 3,5 & 6,3 & 9,0 & 19 & 86 \\
\hline $\mathrm{Be}$ & 4,7 & 3,6 & 1,6 & 6,0 & 4,7 & 6,4 & 3,8 & 5,2 & 8,6 & 4,0 & 2,4 & 3,6 \\
\hline $\mathrm{Sc}$ & 10 & 3,3 & 32 & 6,4 & 5,9 & 6,5 & 5,6 & 1,2 & 2,0 & 4,3 & 8,2 & 5,2 \\
\hline v & 7,2 & 3,7 & 197 & 8,7 & 6,0 & 3,1 & 2,8 & 12 & 3,2 & 7,0 & 12 & 1,0 \\
\hline $\mathrm{Cr}$ & 2,6 & 16 & 143 & 5,5 & 0,67 & 0,99 & 2,3 & 2,5 & 1,7 & 0,92 & 14 & 0,30 \\
\hline Co & 15 & 13 & 38 & 18 & 26 & 14 & 5,2 & 18 & 8,3 & 23 & 18 & 13 \\
\hline $\mathrm{Ni}$ & 2,4 & 8,6 & 67 & 3,5 & 0,72 & 0,62 & 0,58 & 1,1 & 5,0 & 1,7 & 6,523 & 0,90 \\
\hline $\mathrm{Cu}$ & 9,6 & 4,8 & 10,0 & 4,0 & 2,7 & 3,4 & 5,0 & 3,9 & 5,2 & 3,8 & 4,8 & 4,4 \\
\hline $\mathrm{Zn}$ & 31 & 13 & 83 & 22 & 15 & 10 & 25 & 6,3 & 8,2 & 7,2 & 33 & 17 \\
\hline $\mathrm{Ga}$ & 17 & 17 & 24 & 19 & 18 & 18 & 17 & 15 & 19 & 16 & 16 & 16 \\
\hline As & 1,9 & 1,0 & 3,6 & 1,8 & 1,1 & 0,92 & 1,9 & 1,2 & 0,98 & 0,83 & 2,2 & 1,2 \\
\hline $\mathrm{Rb}$ & 214 & 233 & 31 & 285 & 281 & 274 & 351 & 195 & 271 & 190 & 170 & 229 \\
\hline $\mathrm{Sr}$ & 72 & 69 & 622 & 40 & 32 & 24 & 6,3 & 90 & 56 & 133 & 191 & 11 \\
\hline $\mathrm{Cd}$ & 0,11 & 0,11 & 0,24 & 0,11 & 0,12 & 0,14 & 0,096 & $<0,08$ & 0,090 & $<0,08$ & 0,088 & 0,099 \\
\hline In & 0,034 & 0,020 & 0,084 & 0,039 & 0,054 & 0,019 & 0,043 & 0,009 & 0,012 & 0,016 & 0,020 & 0,081 \\
\hline Cs & 1,9 & 3,8 & 2,2 & 11 & 2,4 & 3,1 & 5,6 & 2,2 & 3,1 & 1,6 & 1,5 & 5,7 \\
\hline $\mathrm{Ba}$ & 264 & 229 & 141 & 51 & 41 & 14 & 9,9 & 68 & 66 & 513 & 1542 & 67 \\
\hline $\mathrm{TI}$ & 1,6 & 1,2 & 0,19 & 1,9 & 1,4 & 1,6 & 2,0 & 0,96 & 1,5 & 1,0 & 0,85 & 1,4 \\
\hline $\mathrm{Pb}$ & 5,9 & 24 & 8,3 & 32 & 31 & 31 & 25 & 32 & 35 & 14 & 9,0 & 42 \\
\hline $\mathrm{Bi}$ & 0,25 & 0,10 & 0,21 & 0,39 & 0,06 & 0,09 & 0,17 & $<0,05$ & 1,00 & 0,06 & 0,07 & 1,5 \\
\hline Th & 26 & 30 & 3,4 & 41 & 42 & 44 & 34 & 24 & 1,7 & 28 & 13 & 10 \\
\hline U & 5,2 & 6,3 & 0,62 & 6,4 & 6,0 & 12 & 7,3 & 5,1 & 2,0 & 5,3 & 2,4 & 6,8 \\
\hline $\mathrm{Zr}$ & 75 & 67 & 239 & 60 & 77 & 84 & 95 & 16 & 10 & 69 & 145 & 45 \\
\hline $\mathrm{Nb}$ & 22 & 16 & 13 & 16 & 22 & 21 & 46 & 6 & 9 & 15 & 16 & 21 \\
\hline W & 52 & 54 & 22 & 59 & 91 & 55 & 25 & 68 & 33 & 94 & 67 & 46 \\
\hline La & 21 & 25 & 43 & 22 & 19 & 20 & 14 & 6,8 & 5,9 & 24 & 41 & 19 \\
\hline $\mathrm{Ce}$ & 33 & 39 & 88 & 39 & 37 & 35 & 32 & 9,6 & 8,1 & 40 & 73 & 28 \\
\hline $\mathrm{Pr}$ & 6,1 & 4,1 & 12 & 4,0 & 3,9 & 4,1 & 4,7 & 1,1 & 1,1 & 4,1 & 8,4 & 4,5 \\
\hline
\end{tabular}




\begin{tabular}{ccccccccccccc}
\hline IGM & $\mathbf{9 0 0 9 4 2}$ & $\mathbf{9 0 0 8 7 5}$ & $\mathbf{9 0 0 8 6 8}$ & $\mathbf{9 0 0 9 1 5}$ & $\mathbf{9 0 0 9 6 3}$ & $\mathbf{9 0 0 8 8 9}$ & $\mathbf{9 0 0 8 8 8}$ & $\mathbf{9 0 0 9 0 1}$ & $\mathbf{9 0 0 9 0 4}$ & $\mathbf{9 0 0 9 1 4}$ & $\mathbf{9 0 0 9 6 4}$ & $\mathbf{9 0 0 9 2 6}$ \\
\hline $\mathrm{Nd}$ & 25 & 11 & 48 & 11 & 12 & 12 & $\mathbf{1 8}$ & 3,8 & 3,5 & $\mathbf{9 , 8}$ & $\mathbf{2 8}$ & $\mathbf{1 3}$ \\
\hline $\mathrm{Sm}$ & 6,2 & 1,6 & 9,6 & $\mathbf{1 , 6}$ & 2,2 & 2,1 & 5,8 & 0,81 & $\mathbf{1 , 2}$ & 1,7 & 5,3 & 3,4 \\
\hline $\mathrm{Eu}$ & 0,63 & 0,23 & 1,4 & 0,17 & 0,15 & 0,11 & 0,09 & 0,19 & 0,25 & 0,45 & 1,5 & 0,18 \\
\hline $\mathrm{Gd}$ & 4,5 & 1,4 & 6,6 & 1,4 & 1,6 & 1,7 & 4,3 & 0,58 & 0,78 & 1,5 & 4,0 & 2,6 \\
\hline $\mathrm{Tb}$ & 1,2 & 0,21 & 1,3 & 0,22 & 0,35 & 0,33 & 1,3 & 0,15 & 0,19 & 0,25 & 0,86 & 0,68 \\
\hline $\mathrm{Dy}$ & 7,3 & 1,2 & 7,2 & 1,2 & 1,8 & 1,9 & 8,5 & 0,89 & 1,2 & 1,3 & 4,2 & 4,1 \\
\hline $\mathrm{Ho}$ & 1,5 & 0,26 & 1,3 & 0,27 & 0,39 & 0,43 & 1,8 & 0,19 & 0,22 & 0,30 & 0,88 & 0,89 \\
\hline $\mathrm{Er}$ & 4,8 & 0,95 & 3,8 & 0,98 & 1,4 & 1,5 & 6,2 & 0,62 & 0,67 & 1,0 & 2,8 & 2,7 \\
\hline $\mathrm{Tm}$ & 0,69 & 0,15 & 0,45 & 0,17 & 0,24 & 0,26 & 0,97 & 0,10 & 0,10 & 0,16 & 0,39 & 0,42 \\
\hline $\mathrm{Yb}$ & 4,5 & 1,2 & 2,6 & 1,4 & 1,8 & 2,1 & 6,6 & 0,73 & 0,74 & 1,3 & 2,7 & 3,0 \\
\hline $\mathrm{Lu}$ & 0,66 & 0,22 & 0,33 & 0,25 & 0,31 & 0,36 & 1,00 & 0,11 & 0,11 & 0,21 & 0,42 & 0,44 \\
\hline $\mathrm{Ab}$
\end{tabular}

Abundancia de elementos traza se reporta en partes por millón (ppm)

\subsubsection{Análisis de alteración y clasificaciones de todas las muestras}

Debido a que la mayor parte de las muestras presentan algún grado de alteración, y con el fin de usar los datos geoquímicos para interpretaciones petrogenéticas, se hizo un análisis de la alteración química de las muestras a partir de dos esquemas. El primero, mediante el uso del diagrama de Hughes (1972), donde se aprecia que casi todas las muestras grafican en el campo del espectro ígneo (figura 33), excepto seis muestras (IGM 900943, 900927, 900965, 900944, 900868 y

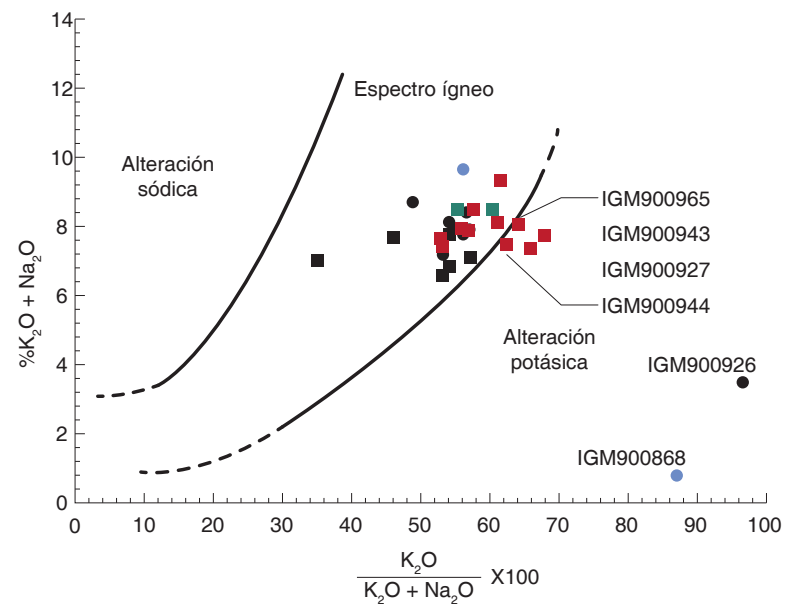

Figura 33. Granitoides del cuerpo principal y de cuerpos menores y diques del Batolito de Mogotes en el diagrama de Hughes (1972)

Cuadrados rojos: monzogranitos, sienogranitos y cuarzomonzonitas; en cuadrados negros, granodioritas, cuarzomonzodioritas, cuarzodioritas y tonalita; cuadros verdes: cuerpos menores; círculos negros: diques jurásicos; círculos azules: diques cretácicos
900926). El segundo abordaje del análisis se hizo con el diagrama de AI vs. CCPI de Large et al. (2001), en el que AI corresponde al índice de alteración de Ishikawa $=100 *\left(\mathrm{MgO}+\mathrm{K}_{2} \mathrm{O}\right) / \mathrm{MgO}+\mathrm{K}_{2} \mathrm{O}+\mathrm{CaO}+\mathrm{Na}_{2} \mathrm{O}$, y el CCPI, al índice pirita-carbonato-clorita. En este diagrama (figura 34), además de cuatro muestras identificadas en el anterior (IGM 900943, 900944, 900868 y 900926), se identifican como muestras alteradas las siguientes: IGM 900900, 900917, 900966, 900942, 900915, 900963, 900904, 900888 y 900901.

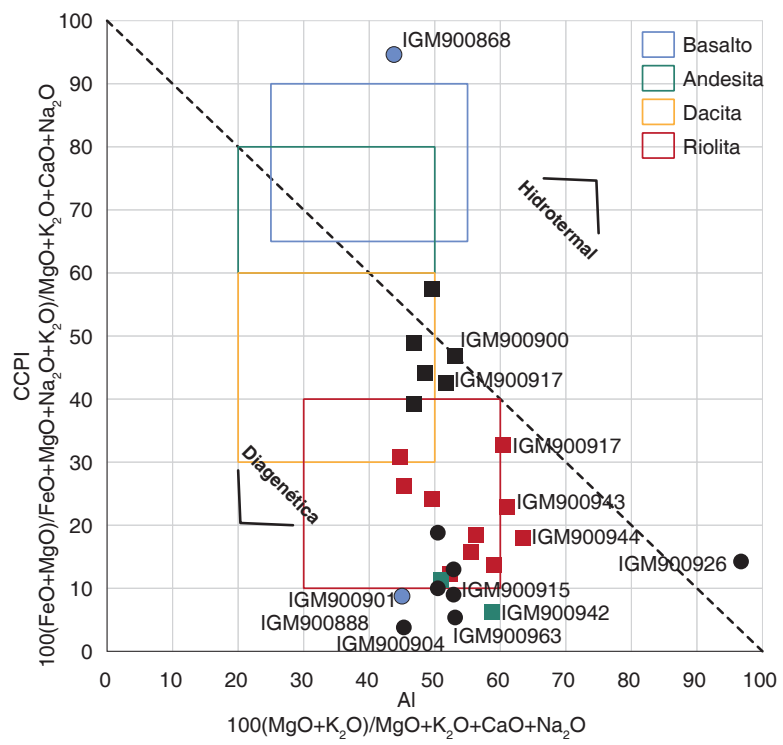

Figura 34. Diagrama de alteración Al vs. CCPI de Large et al. (2001), en el que se muestran las rocas del cuerpo principal, de cuerpos menores y diques del Batolito de Mogotes

Son muestras alteradas las que están por fuera de los campos de riolita, dacita, andesita y basalto (equivalentes volcánicos de granito, granodiorita, tonalita, diorita-gabro). Simbología como en la figura 33 


\section{A}

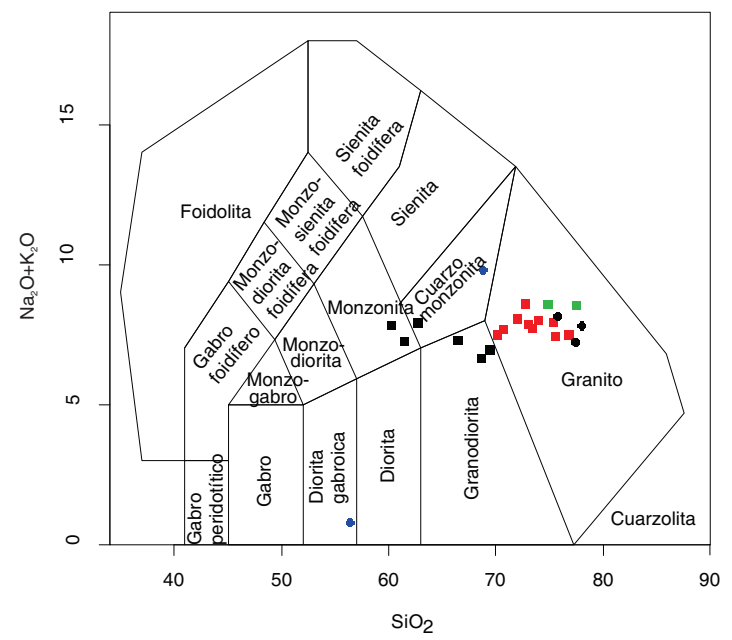

B

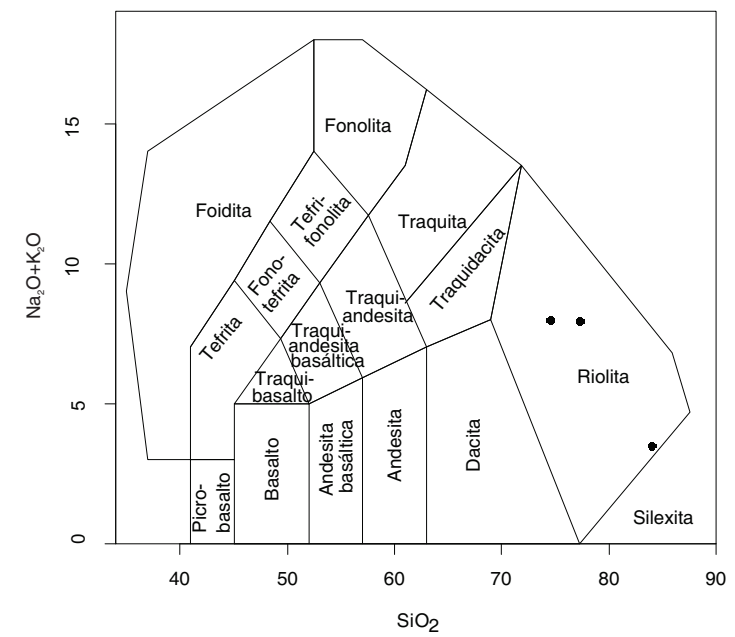

Figura 35. Diagramas TAS de clasificación química en los que se grafican muestras del Batolito de Mogotes A) Clasificación química de rocas plutónicas del cuerpo principal, cuerpos menores y diques del Batolito de Mogotes en diagrama de Middlemost (1985). Cuerpo principal: cuadros rojos (granitos), cuadros negros (granodioritas, monzonitas, cuarzomonzonita). Cuerpos menores: cuadrados verdes. Diques jurásicos: círculos negros. Diques cretácicos: círculos azules. B) Clasificación química de los diques porfídicos de edad Jurásica en el Batolito de Mogotes, en diagrama de Middlemost (1994)

Desde el punto de vista geoquímico, las muestras de los granitoides del cuerpo principal se clasifican en el diagrama de Middlemost (1985), que tiene como variables $\mathrm{SiO}_{2}$ vs. $\mathrm{Na}_{2} \mathrm{O}+\mathrm{K}_{2} \mathrm{O}$, en cuarzomonzonita, cuarzomonzodiorita, granodiorita y granito (figura 35A), la mayoría coincidentes con la clasificación petrográfica. Las rocas graníticas de los cuerpos menores y diques se clasifican químicamente en el campo de los granitos y corresponden a los que petrográficamente se clasificaron como monzogranitos, sienogranitos y granodiorita, exceptuando la muestra IGM900901, que químicamente pertenece al campo de las cuarzomonzonitas, y que petrográficamente se clasificó como un sienogranito. La muestra
IGM900868 se clasificó petrográficamente como una microtonalita alterada, y químicamente corresponde a una diorita gabroica (figura 35A). Los diques porfídicos se clasifican químicamente como riolitas (figura 35B).

En los diagramas usados para discriminar las series de rocas, las muestras de rocas plutónicas según el diagramas de $\mathrm{SiO}_{2}$ vs. $\mathrm{K}_{2} \mathrm{O}$ de Peccerillo y Taylor (1971) pertenecen a la serie calco-alcalina alta en $\mathrm{K}$ (figura 37 A y B), mientras que los diques en el diagrama de Hastie et al. (2007), que fue diseñado para rocas volcánicas alteradas, tres grafican en el campo de la serie calco-alcalina alta en K y un dique cretácico (IGM900868) en la serie calco-alcalina (figura 37B).

\section{A}

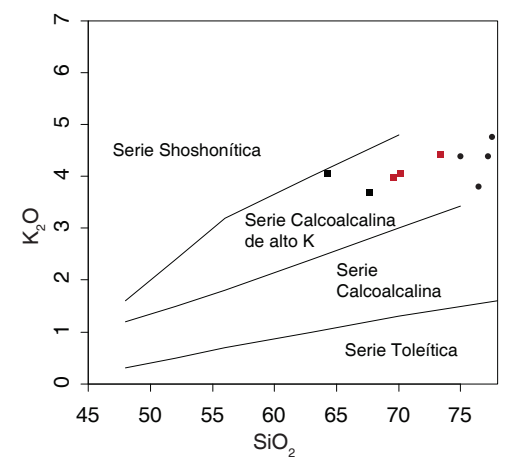

B

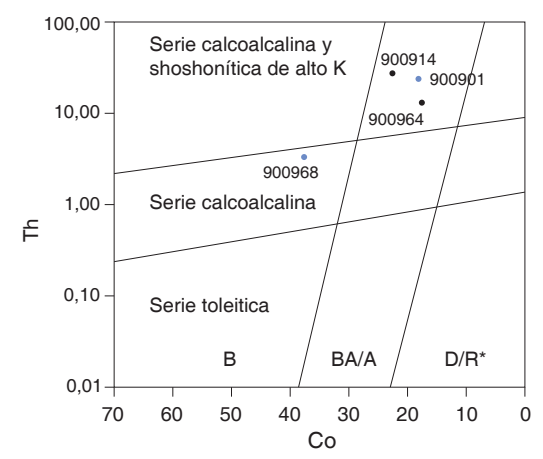

Figura 36. Diagramas para discriminar series de rocas y clasificar rocas volcánicas alteradas

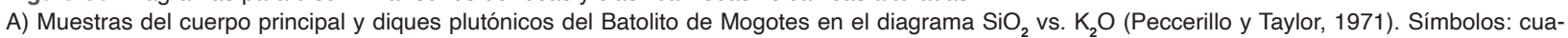
drados rojos: granitoides del cuerpo principal; cuadrados negros: granodioritas, monzonitas, cuarzomonzonita del cuerpo principal; círculos negros: diques jurásicos sienograníticos. B) Muestras de diques subvolcánicos en el diagrama Co vs. Th (Hastie et al., 2007). Símbolos: círculos negros: diques jurásicos; círculos azules: diques cretácicos 
La composición mineralógica de la mayor parte de las muestras estudiadas (feldespato potásico rosado, presencia de hornblenda, presencia de biotita, sin moscovita primaria, cristales de apatito incluidos en la biotita o en la hornblenda, entre otras) es típica de granitos tipo I y propia de rocas metaluminosas a levemente peraluminosas con un índice de saturación en alúmina (ASI) $<$ 1,1 (Chappell y White, 2001). Al comparar el ASI de las muestras analizadas se observan en varias muestras valores altos, por encima de 1,1 en general, hasta 1,4, y un solo valor de 2,2, que sugieren un aumento de la peraluminosidad por un proceso secundario y no ígneo. El aumento en el contenido de $\mathrm{Al}_{2} \mathrm{O}_{3}$ se puede deber a la alteración de plagioclasa a moscovita fina y de la biotita a clorita, evidenciadas en la petrografía.

Las muestras con texturas mirmequíticas también presentan ASI altos. Los crecimientos mirmequíticos pueden ser provocados por un proceso metasomático de Ca, Na y K o representar la desgasificación del magma granítico en las etapas finales de cristalización (Castro Dorado, 2015). En cualquiera de los casos, estas muestras no representan el magma original.

Para interpretar el índice de peraluminosidad y determinar la afinidad de las rocas analizadas con granitos tipo-I o tipo-S no se consideraron las muestras alteradas según la interpretación realizada arriba, aquellas con ASI > 1,1, con excepción de la muestra IGM900889 (ASI $=1,19$, con granate, fase mineral indicativa de rocas peraluminosas) y las que tienen texturas mirmequíticas.

Las muestras interpretadas como menos alteradas se graficaron en el diagrama de Shand (1943), que sirve para determinar la peraluminosidad de las rocas. La mayor parte de las muestras graficadas tienen un ASI < 1, 1 y un carácter levemente peraluminoso (figura 37), excepto la muestra IGM900889, que es más peraluminosa, lo que concuerda con su composición mineralógica. Las rocas exhiben afinidad con granitos tipo-I (figura 38).

\subsubsection{Elementos traza en rocas del cuerpo principal}

Las sumatorias de elementos de las tierras raras $\sum$ REE son superiores a doscientos en once muestras (entre 227 y 303) e inferiores a doscientos en cinco muestras (entre 99 y 183). Los patrones de REE de casi todas las muestras son paralelos y subparalelos y exhiben mayor concentración de tierras raras livianas en comparación con las pesadas, por lo que tienen pendiente negativa, donde las razones $(\mathrm{La} / \mathrm{Yb})_{\mathrm{N}}$ varían entre 10 y 23, excep-

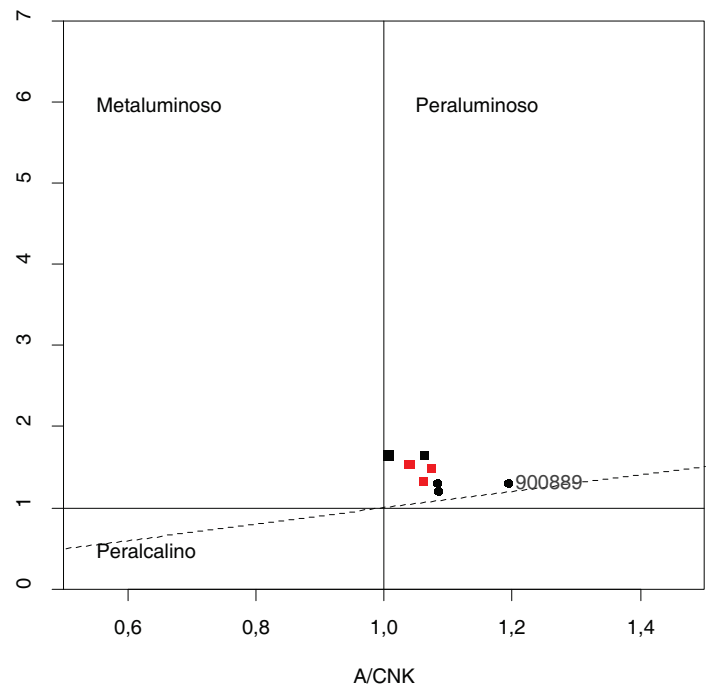

Figura 37. Diagrama de alcalinidad-aluminosidad (Shand, 1943) correspondiente a rocas del Batolito de Mogotes

Cuadrados rojos: granitos del cuerpo principal; cuadrados negros: granodioritas, monzonitas, cuarzomonzonita del cuerpo principal; círculos negros: diques jurásicos

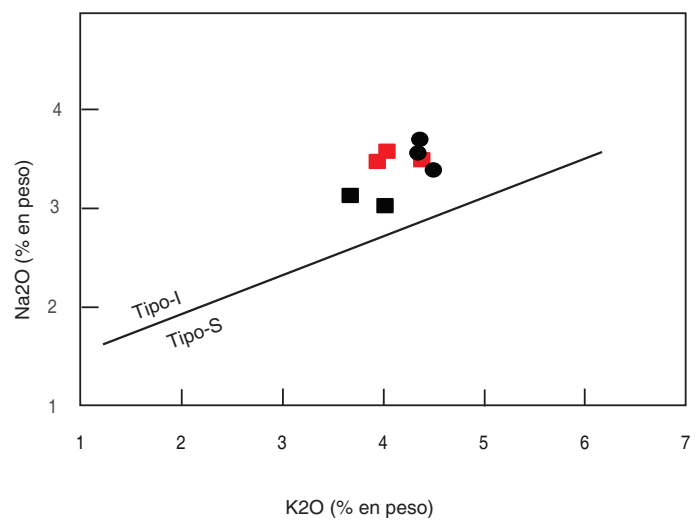

Figura 38. Diagrama $\mathrm{K}_{2} \mathrm{O}$ vs. $\mathrm{Na}_{2} \mathrm{O}$ de Chappell y White (1974) para discriminar entre granitos tipo-I y tipo-S

Cuadrados rojos: granitos del cuerpo principal; cuadrados negros: granodioritas, monzonitas, cuarzomonzonita del cuerpo principal; círculos negros: diques jurásicos

tuando la muestra 900887, que tiene una razón de 4,5, correspondiente con un patrón menos inclinado, y las razones $(\mathrm{Gd} / \mathrm{Yb})_{\mathrm{N}}$ varían entre 0,83 y 2,17 , con un enriquecimiento en tierras raras livianas (LREE) entre 100 y 250 veces los valores del condrito (figura 39 A, C y D), decreciendo a valores entre 10 y 30 veces los del condrito en la tierras raras pesadas (HREE). Hay un conjunto de tres muestras que son monzogranitos gráficos que exhiben unos patrones un poco diferentes (figura 39B), quizá modificados por los procesos responsables de los 
intercrecimientos. Las razones de la mayor parte de las muestras presentan anomalía negativa de $\mathrm{Eu}\left(\mathrm{Eu} / \mathrm{Eu}^{*}=\right.$ 0,43-0,91), que indica fraccionamiento de plagioclasa en la fuente, mientras que solo la muestra IGM 900927 tiene una leve anomalía de Eu, de alrededor de 1,30, que sugiere acumulación de plagioclasa.

En la figura 39A se representan monzogranitos hipidiomórficos (IGM 900944, 900869, 900943 y 900966) con edades entre 198 y 202 Ma. En la figura 39B están los monzogranitos hipidiomórficos con texturas micrográficas locales (IGM 900887, 900965 y 900927), con edad entre 192 y $200 \mathrm{Ma}$. En la figura 39C se representan monzogranitos (IGM 900874, 900962, $900917 \mathrm{y}$ 10VDL32) y granodioritas (10VDL28, 10VDL31) con edades entre 197 y 204 Ma. Y en la figura 39D están los patrones de muestras de granodiorita, cuarzomonzodiorita y monzogranito con hornblenda (IGM 900900, 900902 y 900903), con edades de 192 a 195 Ma.
A

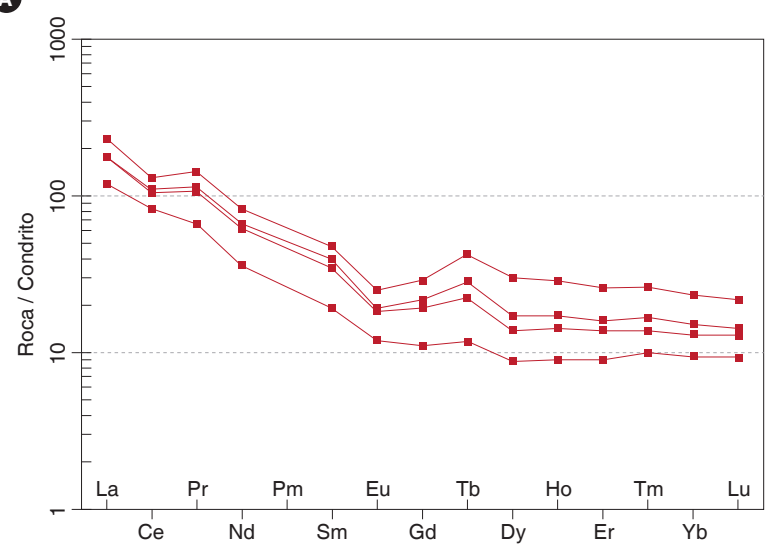

c

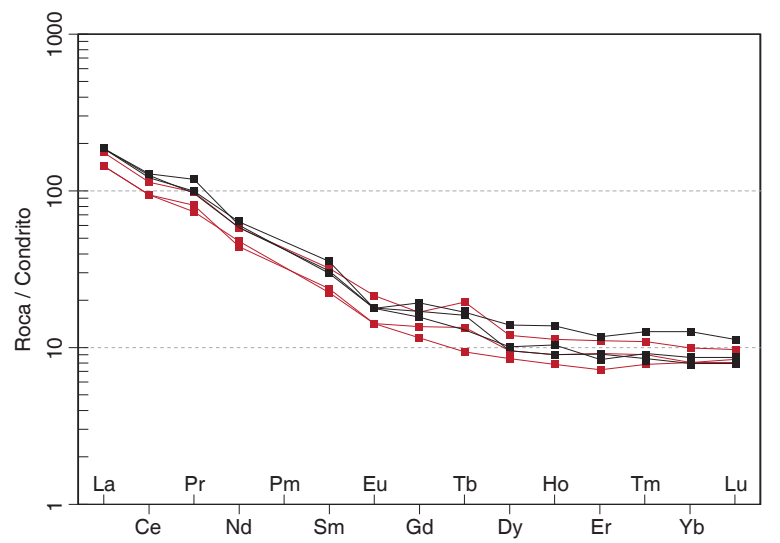

B

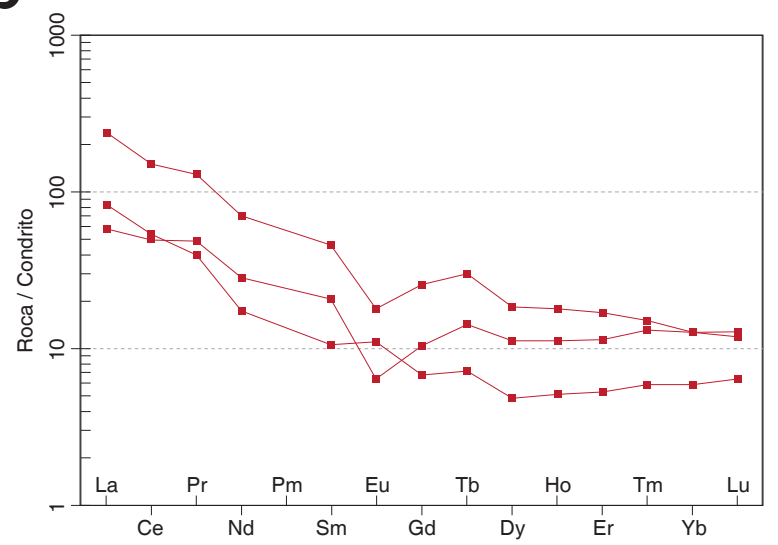

(1)

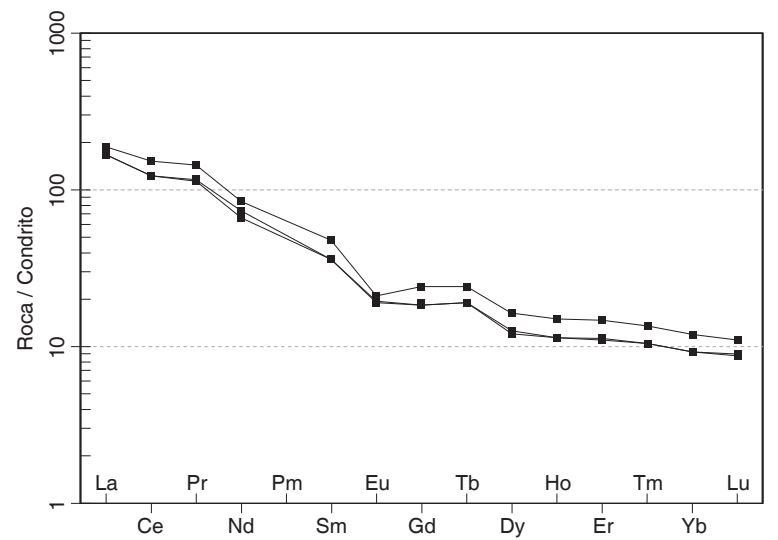

Figura 39. Patrón de elementos de las tierras raras normalizadas al condrito de Nakamura (1974) correspondiente a los granitoides del cuerpo principal del Batolito de Mogotes

A) Monzogranitos hipidiomórficos (IGM 900944, 900869, 900943 y 900966). B) Monzogranitos hipidiomórficos con texturas micrográficas locales (IGM 900887, 900965 y 900927). C) Monzogranitos (IGM 900874, 900962, 900917 y 10VDL32) y granodioritas (10VDL28, 10VDL31). D) Granodiorita, cuarzomonzodiorita y monzogranito con hornblenda (IGM 900900, 900902 y 900903) 
En los diagramas multielementales (figura 40) normalizados contra el NMORB (Sun y McDonough, 1989) se muestran los patrones de las mismas muestras de la figura 39. Las rocas graníticas en general exhiben patrones muy similares entre sí. Presentan enriquecimiento en los elementos litófilos de radio iónico grande (LILE) con relación al N-MORB tales como Cs, Rb, Th, U, K, y anomalías negativas de elementos de alta intensidad iónica de campo (HFSE), tales como Nb, P y Ti, que indican un origen relacionado con subducción. Leves anomalías negativas de Ba se observan en las muestras IGM 900965 y 900887, mientras todas las muestras exhiben anomalía positiva de $\mathrm{Pb}$.
A

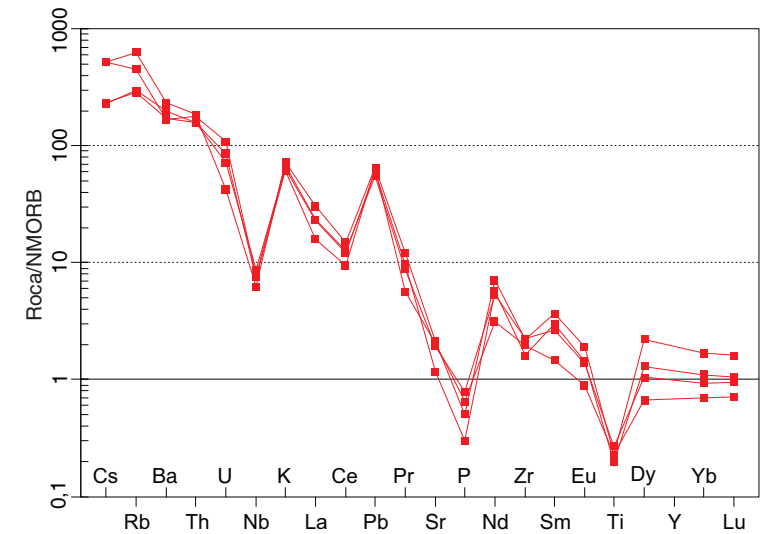

c

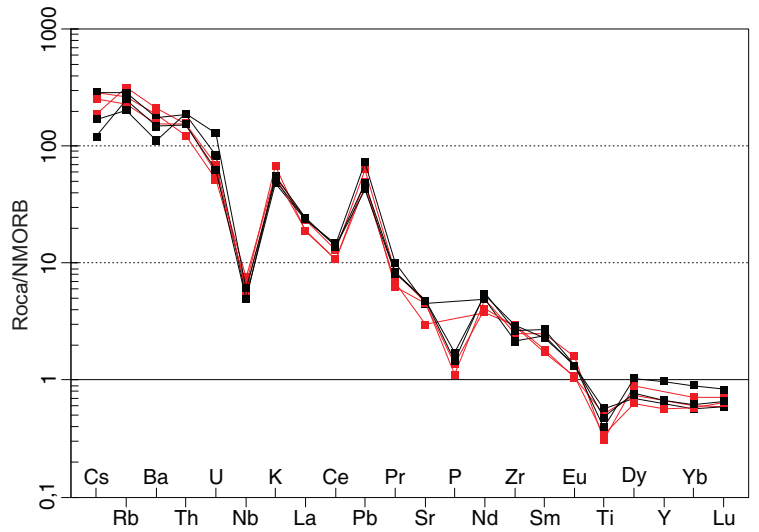

B

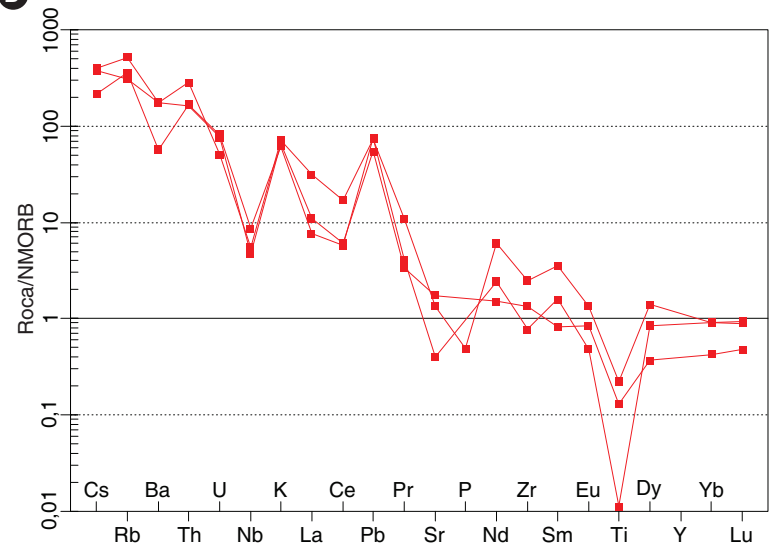

(D)

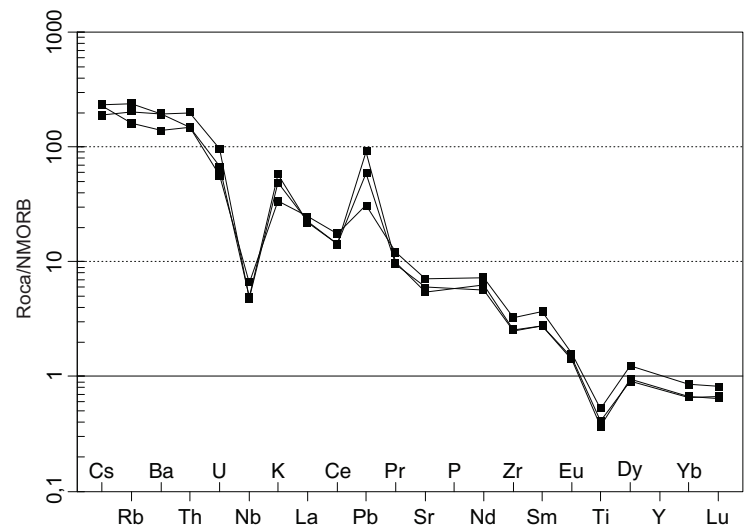

Figura 40. Diagramas multielementales normalizados al NMORB (Sun y McDonough, 1989) correspondientes a los granitoides del cuerpo principal del Batolito de Mogotes. A) Monzogranitos hipidiomórficos (IGM 900944, 900869, 900943 y 900966). B) Monzogranitos hipidiomórficos con texturas micrográficas locales (IGM 900887, 900965 y 900927). C) Monzogranitos (IGM 900874, 900962, 900917, 10VDL32) y granodioritas (10VDL28, 10VDL31). D) Granodiorita, cuarzomonzodiorita y monzogranito con hornblenda (IGM 900900, 900902 y 900903 ) 


\subsubsection{Elementos traza en cuerpos menores y diques}

Los patrones de REE de los cuerpos menores de dos muestras (IGM900942 y 900875) difieren entre sí (figura 41 A), lo que sugiere que estos dos cuerpos no son cogenéticos. La muestra IGM900942 tiene un contenido de tierras raras $\sum$ REE de 11 7, y la IGM900875, de 87. Ambas exhiben enriquecimiento en los LREE con relación a los HREE, siendo que la muestra IGM900942 presenta una razón $(\mathrm{La} / \mathrm{Yb})_{\mathrm{N}}$ de 3,1 2, una razón $(\mathrm{Gd} / \mathrm{Yb})_{\mathrm{N}}$ de 0,81 y una anomalía negativa de Eu de 0,36, mientras que en la muestra IGM900875 la razón $(\mathrm{La} / \mathrm{Yb})_{\mathrm{N}}$ es de 13,32 , la $(\mathrm{Gd} / \mathrm{Yb})_{\mathrm{N}}$ es de 0,91 , mientras que la anomalía de Eu es de 0,48.

En los diques es posible diferenciar por lo menos tres tipos de patrones de REE, como se muestran en la figura 41 B, C y D. El primer tipo (figura 41B) lo representan cinco muestras, cuya sumatoria de contenidos de los elementos de las tierras raras ( $\sum$ REE) varía entre 82 y 106 . Este tipo de patrón se caracteriza por ser casi pla- no a enriquecidos en LREE y con forma plana a cóncava en los HREE, tiene $(\mathrm{La} / \mathrm{Yb})_{\mathrm{N}}$ entre 1,46 y 1 0,27, $(\mathrm{Gd} / \mathrm{Yb})_{\mathrm{N}}$ entre 0,52 y 0,80 y anomalía negativa de Eu muy pronunciada, entre 0,06 y 0,34. El segundo tipo de patrones está representado por cuatro muestras, en las que a la vez es posible distinguir dos subtipos, uno (IGM900964 e IGM900914) con $\sum$ REE entre 86 y 173 , (La/Yb) ${ }_{\mathrm{N}}$ entre 10 y $12,(\mathrm{Gd} / \mathrm{Yb})_{\mathrm{N}}$ entre 0,95 y 1,19 y leve anomalía de Eu (0,88-0,98), que es más enriquecido en REE que el otro (IGM900901 e IGM900904), que tiene un contenido de tierras raras totales bajo ( $\sum$ REE entre 24 y 26), también un patrón menos enriquecido en LREE con una relación $(\mathrm{La} / \mathrm{Yb})_{\mathrm{N}}$ entre 5 y $6,(\mathrm{Gd} / \mathrm{Yb})_{\mathrm{N}}$ de 0,64 y 0,84 y una leve anomalía de Eu (0,79-0,84). Los cuatro muestran un patrón suavemente cóncavo. El tercer tipo de patrón lo representa una sola muestra, la IGM900868, con una sumatoria de REE de 225, patrón de REE con pendiente negativa, una relación $(\mathrm{La} / \mathrm{Yb})_{\mathrm{N}}$ de $11,(\mathrm{Gd} / \mathrm{Yb})_{\mathrm{N}}$ de $2,06 \mathrm{y}$ anomalía negativa de Eu de 0,55.
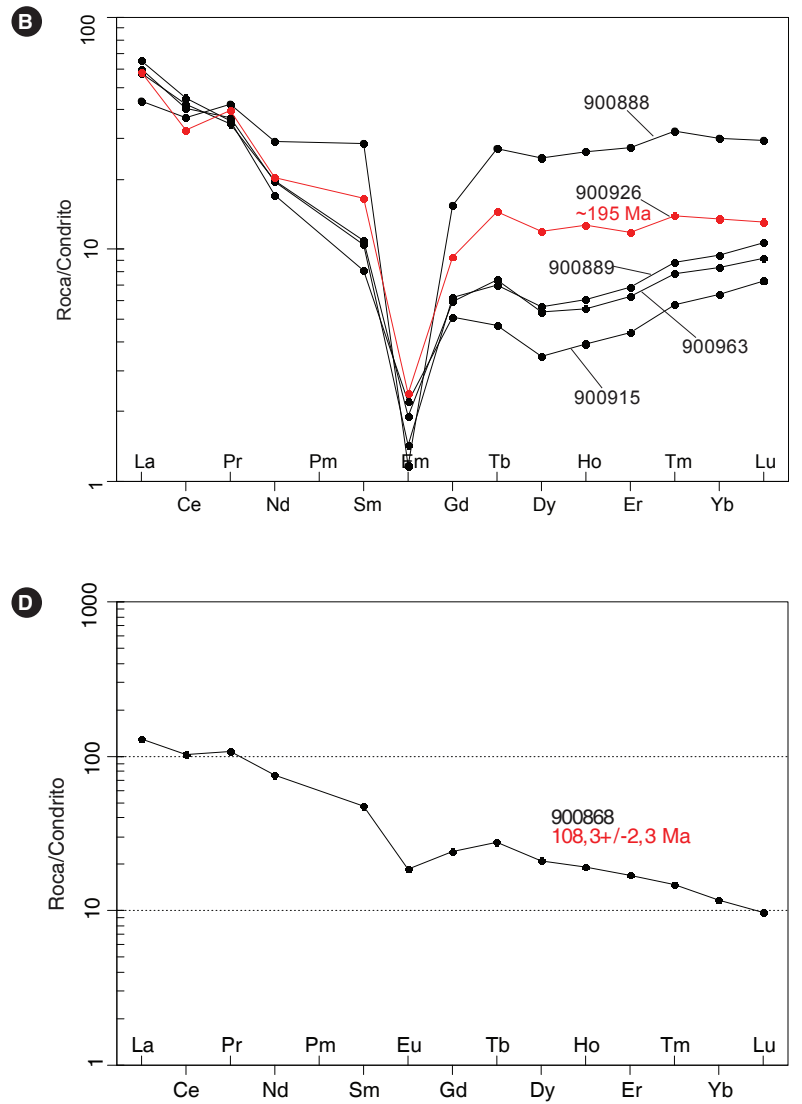

Figura 41. Patrones de elementos de tierras raras normalizados al condrito de Nakamura (1974), de los cuerpos menores (A) y diques (B, C y D) del Batolito de Mogotes 
En los diagramas multielementales normalizados contra el NMORB (Sun y McDonough, 1989), las rocas de los cuerpos menores (figura 42A) tienen patrones parecidos y exhiben enriquecimiento en los LILEs. Tienen anomalías negativas de $\mathrm{Nb}$ y Ti relacionadas con un origen en zonas de subducción y anomalías negativas de Ba y positivas de $\mathrm{Pb}$.

Los elementos traza en los diques de sienogranitos y monzogranitos tienen patrones parecidos en la mayor parte de las muestras, con algunas diferencias (figura 42B) en dos de ellas: IGM900904 y 900901 . Exhiben enriquecimiento en los LILEs, pero con fuerte anomalía negativa de $\mathrm{Ba}$. Tienen anomalía positiva de $\mathrm{Pb}$. Todas exhiben anomalías negativas de $\mathrm{Nb}$ y de Ti, excepto la IGM900889, lo cual sugiere un origen relacionado con subducción. Las muestras IGM900904 y 900901 tienen
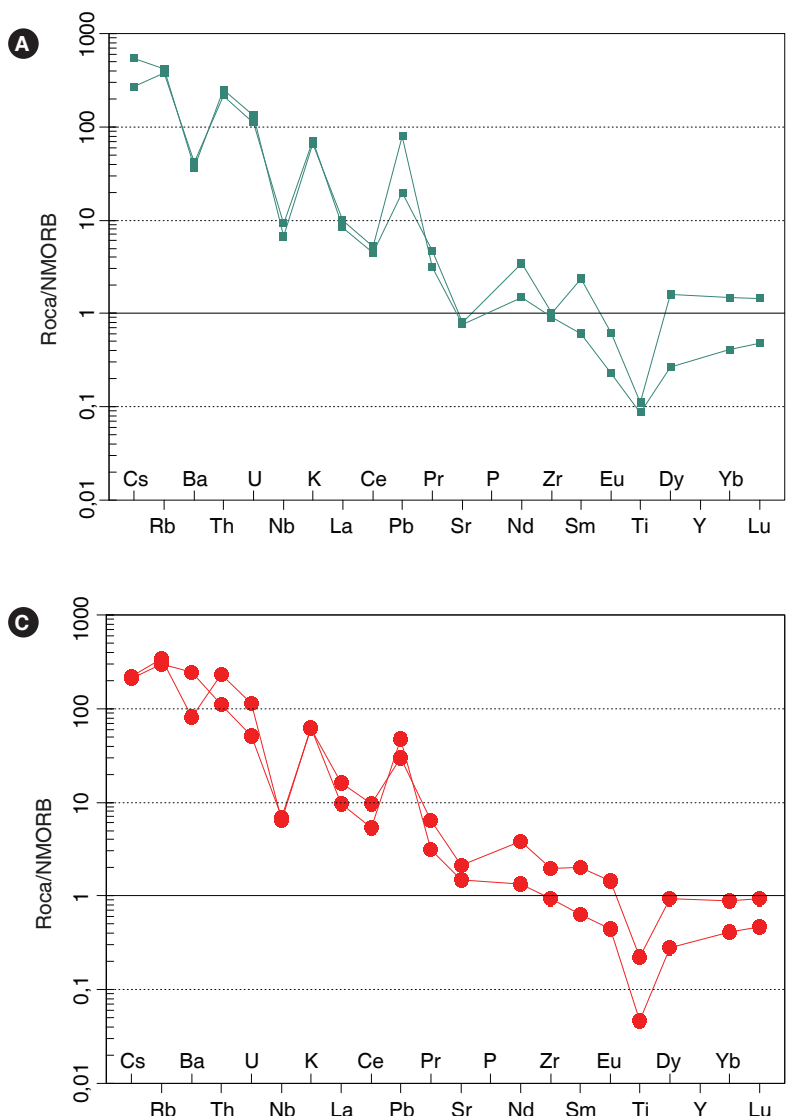

menores contenidos de La, Ce, Nd, Zr, Sm, Yb y Lu que las otras muestras, de las que se diferencian también porque no presentan anomalía negativa de Sr.

Los elementos traza de la cuarzolatita y la riolita porfídica despliegan patrones multielementales semejantes (figura 42C), con la diferencia de que la muestra IGM 900964 no tiene anomalía negativa de Ba. Están enriquecidos en LILEs y, al igual que los sienogranitos y monzogranitos, registran anomalías negativas de $\mathrm{Nb}$ y Ti, que indican un origen relacionado con subducción.

El patrón multielemental del dique de dolerita IGM900868 difiere en forma (figura 42D) de los patrones de los otros diques; sin embargo, también presenta las mismas anomalías de $\mathrm{Ba}, \mathrm{Pb}$ y las negativas de $\mathrm{Nb}$ y Ti; estas dos últimas indican origen relacionado con subducción.
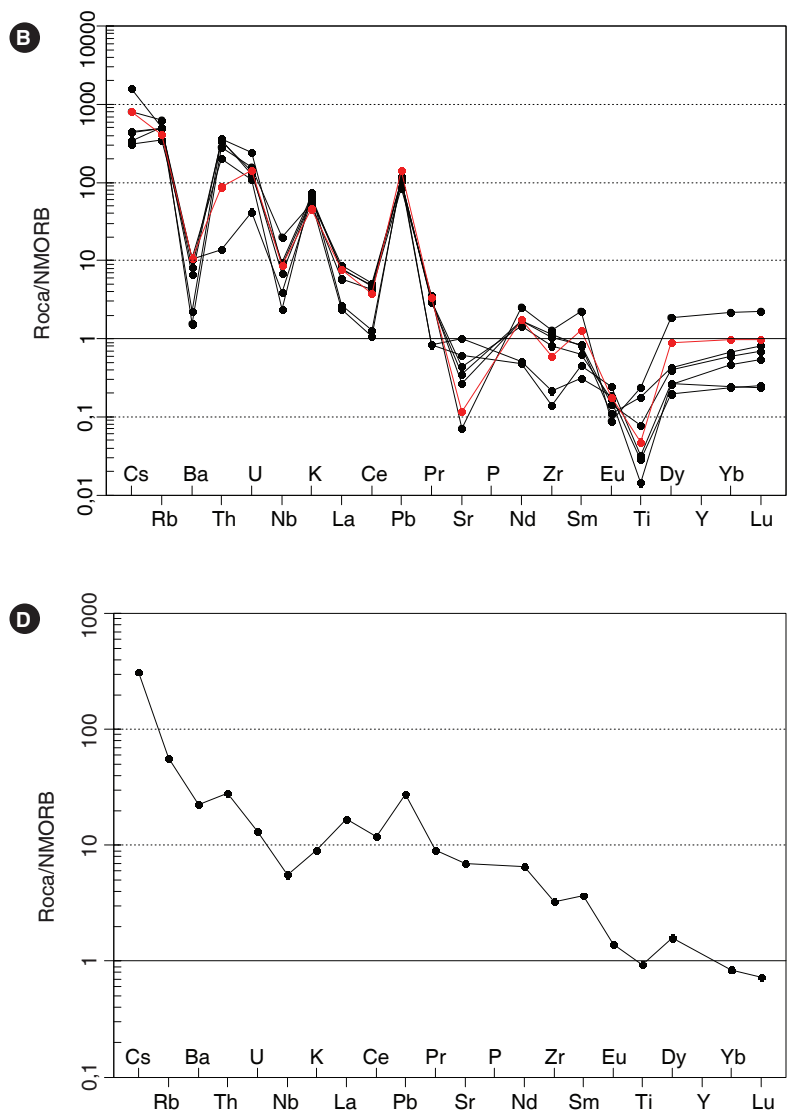

Figura 42. Diagramas multielementales normalizados al NMORB (Sun y McDonough, 1989) correspondientes a los cuerpos menores y diques del Batolito de Mogotes. A) Cuerpos menores (IGM 900942 y 900975). B) Diques de sienogranitos y monzogranitos (IGM 90088, 900926, 900889, 900963, 900915, 900904 y 900901). C) Diques de cuarzolatita (IGM900964) y riolita (IGM900914) porfídicas. D) Dique de microtonalita o diorita gabroica (IGM900868) 


\section{Posición estratigráfica y edad}

Hacia el oriente, el Batolito de Mogotes se encuentra limitado por la falla de Bucaramanga. La unidad intruye al Neis de Bucaramanga, el Ortoneis y las formaciones Floresta y Silgará (Ward et al., 1973). En este trabajo se encontraron afloramientos en los que las rocas del Batolito de Mogotes intruyen la formación Silgará al NE de San Joaquín, varios kilómetros más al oeste de lo que aparece en los mapas geológicos de la zona. El flanco occidental de la unidad se encuentra en contacto con las formaciones Silgará y Floresta. Al norte, el batolito se encuentra en contacto con el Monzogranito de Santa Bárbara y con el Granito de Pescadero, sobre el cual Ward et al. (1973) mencionan que se ha considerado como parte del Batolito de Mogotes.

Goldsmith et al. (1971) interpretan que el Batolito de Mogotes tiene la misma edad que el Granito de Pescadero
(193 +/-6 Ma por el método K/Ar en biotita), por considerar que este último hace parte del primero. Esta relación entre el Batolito de Mogotes y el Granito de Pescadero es también sugerida por Ward et al. (1973) basándose en la semejanza general de su litología, fases gradacionales y relaciones estratigráficas. Royero y Clavijo (2001) mencionan que existen unos pequeños plutones del Silúrico-Devónico Superior de composición monzonítica que pertenecen "en parte" al Batolito de Mogotes; uno de estos pequeños plutones es la Monzonita de Onzaga, de la que se obtuvo una edad K/Ar de $394 \pm 23 \mathrm{Ma}$ (Cordani, comunicación escrita en 1982, en Etayo Serna et al., 1985).

Dataciones realizadas específicamente en muestras del Batolito de Mogotes corresponden a las de Van der Lelij (2013), quien obtuvo tres edades U/Pb en circón en tres muestras del extremo sur de la unidad. Los resultados presentados por este autor se muestran a continuación:

Tabla 11. Edades U-Pb en circón en muestras del Batolito de Mogotes calculadas por Van der Lelij (2013)

\begin{tabular}{|c|c|c|c|}
\hline Muestra & 10VDL28 & 10VDL31 & 10VDL32 \\
\hline Este & 1139319 & 1139249 & 1138599 \\
\hline Norte & 1196909 & 1200504 & 1202162 \\
\hline Plancha & 152 & 136 & 136 \\
\hline Roca & Granodiorita & Granodiorita & Granodiorita \\
\hline Unidad & Granodiorita de Onzaga & Granodiorita de Onzaga & Granodiorita de Mogotes \\
\hline Edad (Ma) & $200,4 \pm 0,7$ & $201 \pm 0,9$ & $198 \pm 0,8$ \\
\hline
\end{tabular}

Fuente: Van der Lelij (2013)

En este proyecto se obtuvieron edades U-Pb por LAICP-MS (laser ablation-inductively coupled plasma-mass spectrometry) en varias muestras del Batolito de Mogotes, cuerpos menores y diques, representativas de los litotipos identificados, y en lo posible se buscó obtener la edad de cada uno de los grupos geoquímicos con patrones de elementos de las tierras raras (REE) semejantes.

Los análisis de este proyecto fueron realizados en dos laboratorios: unos se hicieron en el Laboratorio de Ablación Láser del Servicio Geológico Colombiano, en Bogotá, y otros en el Laboratorio de Estudios Isotópicos del Centro de Geociencias de la Universidad Autónoma de México. Los datos obtenidos en las muestras de circones fueron manipulados en el software Isoplot/Ex 3.75-4.15 (Ludwig, 2012). Con el fin de mejorar el rango de confiabilidad de la edad, se filtraron los datos para descartar los circones con discordancias mayores del 15\%, de acuerdo con la relación $\left[\left({ }^{207} \mathrm{~Pb} /{ }^{235} \mathrm{U}-{ }^{206} \mathrm{~Pb} /{ }^{238} \mathrm{U}\right) /\left({ }^{206} \mathrm{~Pb} /{ }^{238} \mathrm{U}\right)\right]$, o valores de error mayores de $5 \%$ en la mayor parte de las muestras. Otros criterios aplicados a algunas muestras se especifican en la muestra correspondiente. En todos los casos las edades reportadas menores de 800 Ma corresponden a las obtenidas a partir de la relación ${ }^{206} \mathrm{~Pb} /{ }^{238} \mathrm{U}$, mientras que las mayores de $800 \mathrm{Ma}$ son las arrojadas por la relación ${ }^{207} \mathrm{~Pb} /{ }^{206} \mathrm{~Pb}$. Los resultados se resumen en la tabla 12 . 
Tabla 12. Resumen edades U-Pb en circón de monzogranitos, granodioritas, cuerpos menores (*) y diques del Batolito de Mogotes

\begin{tabular}{|c|c|c|c|c|c|c|c|}
\hline IGM & N. ${ }^{\circ}$ campo & $\mathbf{N}$ & w & Clasificación petrográfica & Edad U-Pb (Ma) & MSWD & Edades heredadas \\
\hline 900962 & TCR-376 & 1231161 & 1124265 & Monzogranito & $203 \pm 1$ & 2,6 & $(1000 \pm 160, n=1)$ \\
\hline 900944 & MIA-638 & 1217144 & 1126040 & Monzogranito & $200 \pm 2$ & 6,7 & $\begin{array}{c}(1627 \pm 77, \mathrm{n}=1 ; 1120 \pm 79, \mathrm{n}=1 ; 316,9 \pm 6,8, \mathrm{n}=1 ; \\
234,4 \pm 7,1, \mathrm{n}=1)\end{array}$ \\
\hline 900927 & LMC-075 & 1208090 & 1131045 & Monzogranito & $196 \pm 4$ & 7,2 & $(1230 \pm 43, n=1 ; 1040-1020 \pm 34, n=2 ; 248,5 \pm 10, n=1)$ \\
\hline 901525 & AMC-0162 & 1206436 & 1137867 & Monzogranito deformado & $200 \pm 1 ; 189 \pm 1$ & $\begin{array}{l}1,0 \\
2,0\end{array}$ & $\begin{array}{c}(1282 \pm 36, \mathrm{n}=1 ; 1069 \pm 51, \mathrm{n}=1 ; 988 \pm 38, \mathrm{n}=1 ; 800 \pm \\
33, \mathrm{n}=1 ; 680-650, \mathrm{n}=2 ; 585, \mathrm{n}=2 ; 513, \mathrm{n}=1 ; 460-420 \\
\mathrm{n}=11 ; 405-360, \mathrm{n}=10 ; 353-337, \mathrm{n}=5 ; 296-249, \mathrm{n}=7 \\
249-231, \mathrm{n}=5)\end{array}$ \\
\hline 900903 & GZ-6831 & 1206394 & 1140363 & Cuarzomonzodiorita deformada & $194 \pm 1$ & 1,9 & $(905 \pm 25, n=1 ; 287,7 \pm 8,8, n=1 ; 268,3 \pm 7,6, n=1)$ \\
\hline 900942 & MIA-636 $\left({ }^{*}\right)$ & 1230947 & 1122841 & Monzogranito micrográfico & $205 \pm 3$ & 13 & $(1316 \pm 76, n=1 ; 571,7 \pm 6, n=1)$ \\
\hline 900875 & AMC-0144(*) & 1202313 & 1136936 & Sienogranito aplítico & $202 \pm 2$ & 4,6 & $(435 \pm 6,7, n=1)$ \\
\hline \multirow[t]{2}{*}{900926} & LMC-071 & 1222482 & 1122453 & Dique de cuarzolatita hidrotermalizada & & & $(520 \pm 22, n=2 ; 486 \pm 18, n=1)$ \\
\hline & TCR-380 & 1207654 & 1129709 & Dique básico en cuarzomonzonita & $191 \pm 4$ & 4,2 & $\begin{array}{c}\text { (923-851, } \mathrm{n}=4 ; 448-432, \mathrm{n}=4 ; 399-391, \mathrm{n}=2 ; 330-302, \mathrm{n} \\
=3 ; 267, \mathrm{n}=1 ; 215, \mathrm{n}=1)\end{array}$ \\
\hline 900868 & AMC-0136A & 1238967 & 1123996 & Dique de microtonalita & $108 \pm 2$ & 4,1 & $\begin{array}{c}(1335 \pm 40, \mathrm{n}=1 ; 1154 \pm 35, \mathrm{n}=1 ; 250 \pm 10, \mathrm{n}=1 ; 221 \\
\pm 8, \mathrm{n}=1)\end{array}$ \\
\hline 900901 & GZ-6829B & 1204364 & 1140288 & Dique de sienogranito & $99 \pm 2$ & 1,6 & $(214 \pm 7 ; 207 \pm 7 ; 199 \pm 6, n=2)$ \\
\hline
\end{tabular}

MSWD (mean square weighted deviation) que en español es media cuadrática de desviaciones ponderadas

\subsection{Edades de las rocas del cuerpo principal}

La muestra TCR-37 6 fue colectada en el camino La Palma-Chicamocha, hacia la parte septentrional del Batolito de Mogotes. Los circones de esta muestra son euhedrales a subhedrales, de forma prismática corta y larga, siendo más comunes los prismáticos cortos, la mayoría de color rosado pálido, algunos amarillo pálido y otros incoloros; casi todos presentan inclusiones. Los tamaños varían entre 70 y 300 micras, si bien predomina el rango situado entre 100 y 180 micras. La muestra fue analizada en el Laboratorio de Estudios Isotópicos del Centro de Geociencias de la Universidad Autónoma de México. Los resultados isotópicos se encuentran en el anexo 1.1. En imágenes de catodoluminiscencia (CL) los circones más grandes muestran zonación oscilatoria (figura 43), mientras que los cristales de entre 100 y 120 $\mu \mathrm{m}$ son más homogéneos.

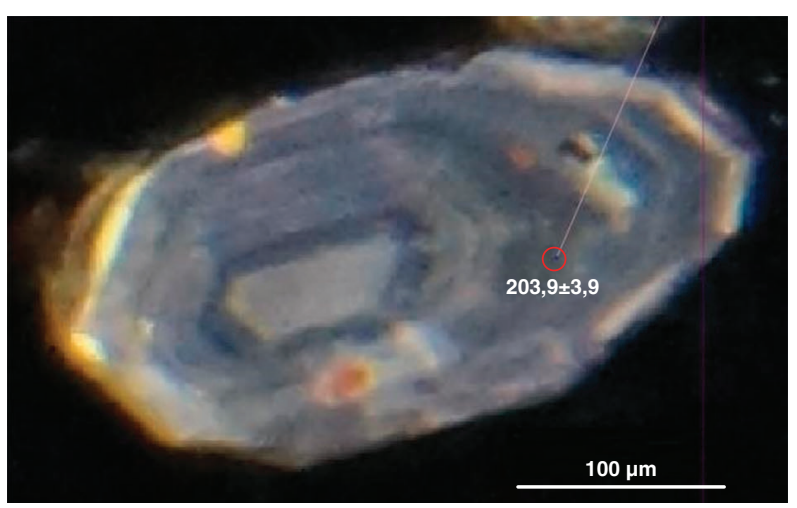

Figura 43. Imagen de catodoluminiscencia de circón fechado en la muestra TCR-376
Exceptuando dos valores, uno de un circón heredado de $\sim 900$ Ma y otro que tuvo posiblemente pérdida de $\mathrm{Pb}$ a los ca. $90 \mathrm{Ma}$, los datos se agrupan en el límite Jurásico-Triásico (figura 44A) principalmente entre 208 y $193 \mathrm{Ma}$; hay un solo valor de $211 \mathrm{Ma}$. La edad media ponderada de esta muestra es de $203 \pm 1 \mathrm{Ma}$ (figura 44B), con un MSWD de 2,6.

La mayor parte de los puntos analizados exhiben razones $\mathrm{Th} / \mathrm{U}$ por encima de 0,6 y cercanos a 1 (figura 45), que corroboran el carácter ígneo de los circones (Rubatto, 2002).

Los resultados de elementos de las tierras raras de esta muestra están en el anexo 2.1. En el diagrama de patrones de elementos de las tierras raras de los circones (figura 46) se aprecia que la mayor parte son paralelos y subparalelos, con anomalías positivas de Ce y negativas de Eu semejantes a los patrones de los circones ígneos; algunos patrones muestran enriquecimiento en las tierras raras livianas (LREE), que puede deberse a que en dicho punto fue analizada alguna microinclusión de un mineral rico en LREE, por ejemplo, monacita. De acuerdo con los contenidos de $\mathrm{Pb}$ y Th (figura 47), los circones de la muestra TCR-376 son de un granito tipo-I.

La muestra MIA-638 hace parte del cuerpo principal y fue colectada en la vía Mogotes-Los Manzanos, en el sector centro-occidental del batolito. Los circones son de euhedrales achatados a prismáticos cortos, con pirámides poco desarrolladas y, en algunos casos, ovoidales, transparentes, de tonalidad parda tenue. Los circones del montaje son superiores a $200 \mathrm{~mm}$ en su dimensión mayor; los ovoidales son los de mayor tamaño. 
La muestra fue analizada en el Laboratorio de Estudios Isotópicos del Centro de Geociencias de la Universidad Autónoma de México; los resultados de los análisis isotópicos se pueden consultar en el anexo 1.2. Esta muestra presenta algunos circones heredados cuyas

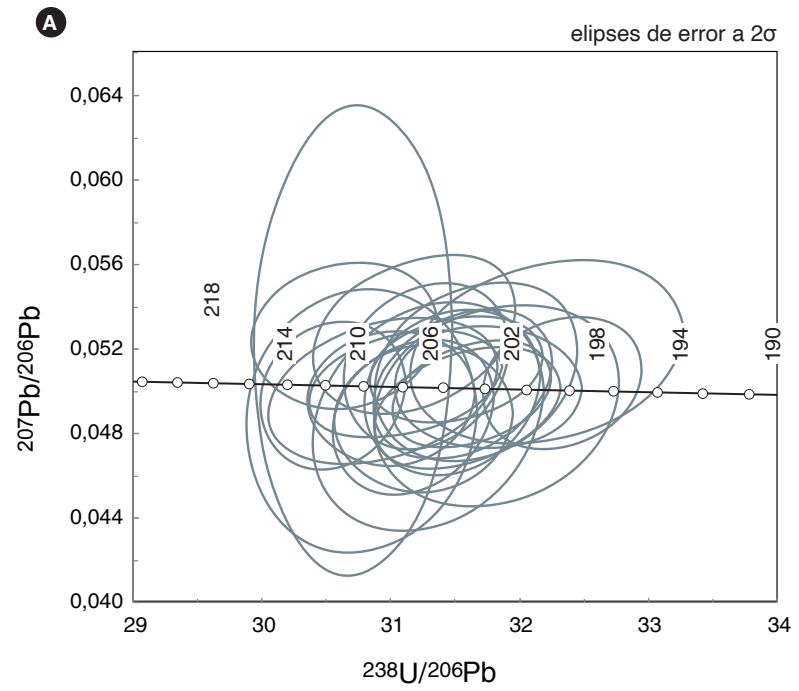

edades se resumen en la tabla 12 , mientras que la mayoría de los datos se agrupan en el límite Triásico-Jurásico (figura 48A), y van desde 215 hasta 188 Ma. La edad media obtenida es de $200 \pm 2$ (figura 48B), con MSWD de 6,7 .

Figura 44. Resultados geocronológicos de la muestra TCR-376. A) Concordia Tera-Wasserburg que muestra los resultados U-Pb en circón de la muestra TCR-376. B) Edad media ponderada de la muestra

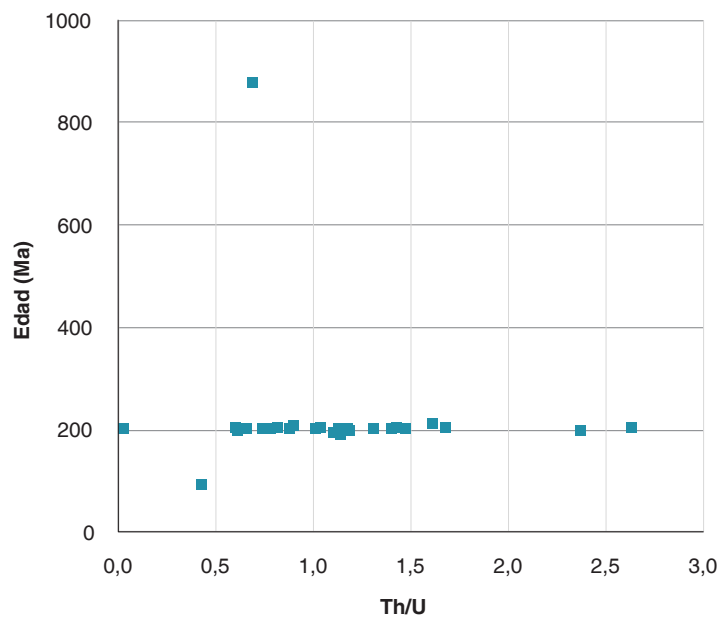

Figura 45. Diagrama de relación Th/U vs. edad en circones de la muestra TCR-376
B

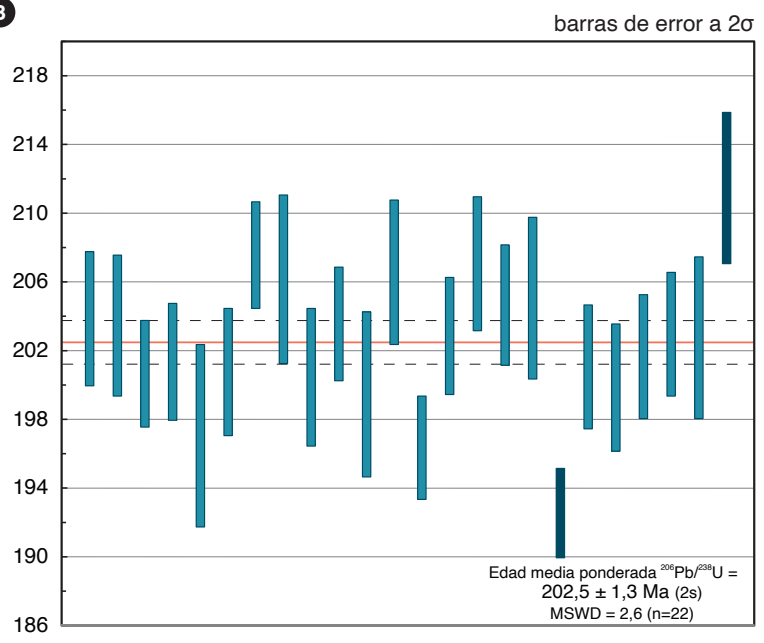




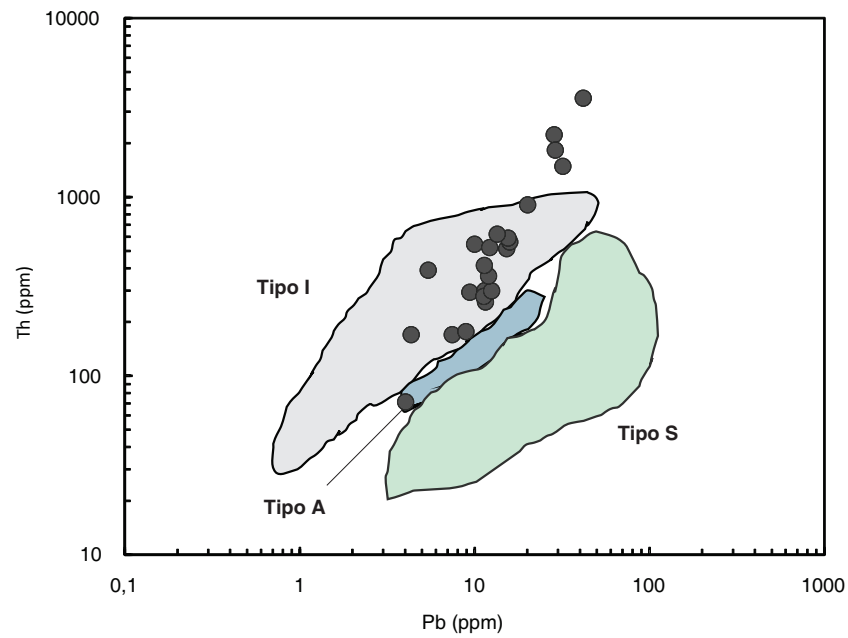

Figura 47. Diagrama Pb vs. Th de Wang et al. (2012) correspondiente a la muestra TCR-376

(4)

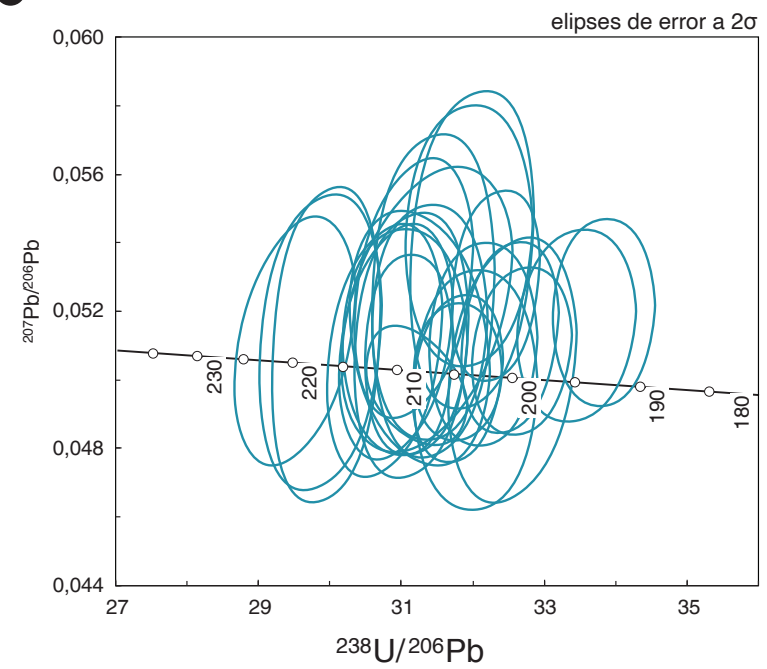

B

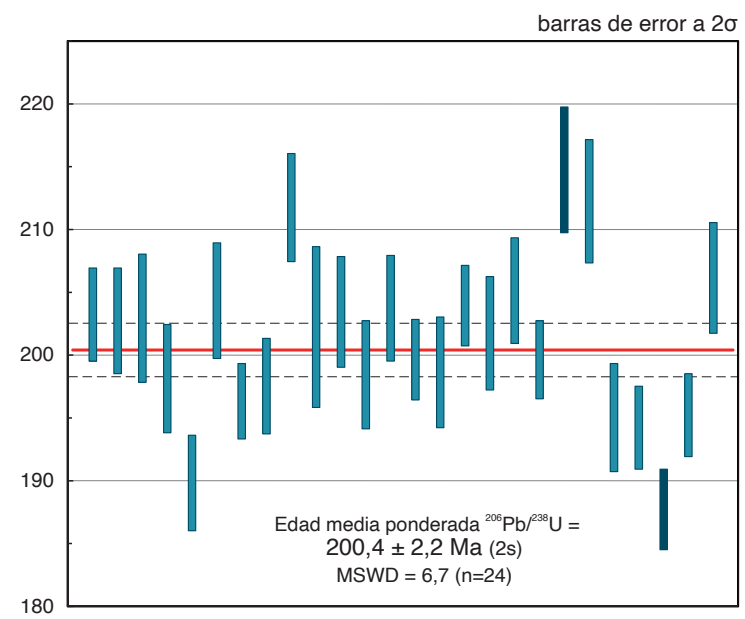

Figura 48. A) Concordia Tera-Wasserburg que muestra los resultados U-Pb. B) Edad media de la muestra MIA-638

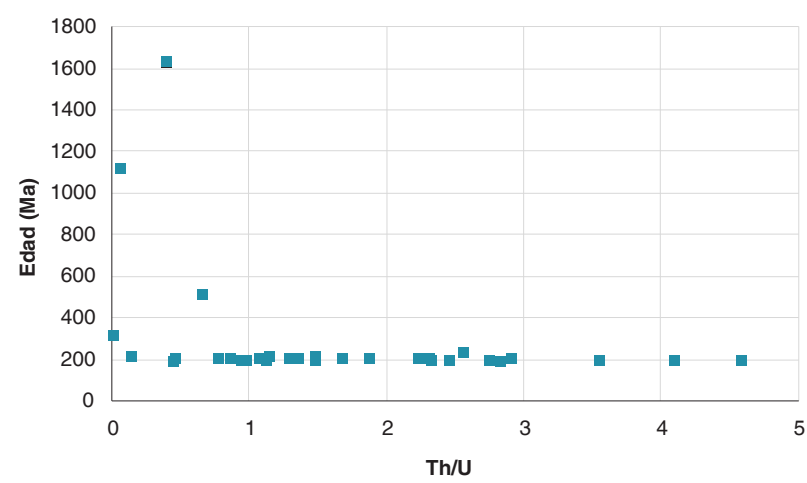

Figura 49. Diagrama de relación Th/U vs. edad en circones de la muestra MIA-638 
A

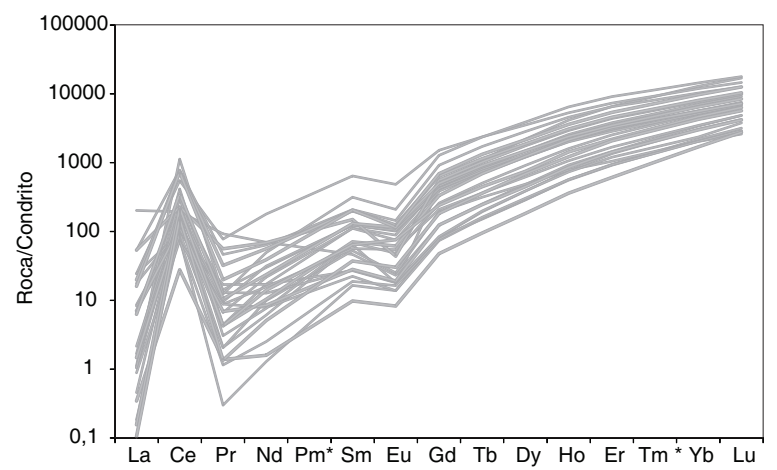

B

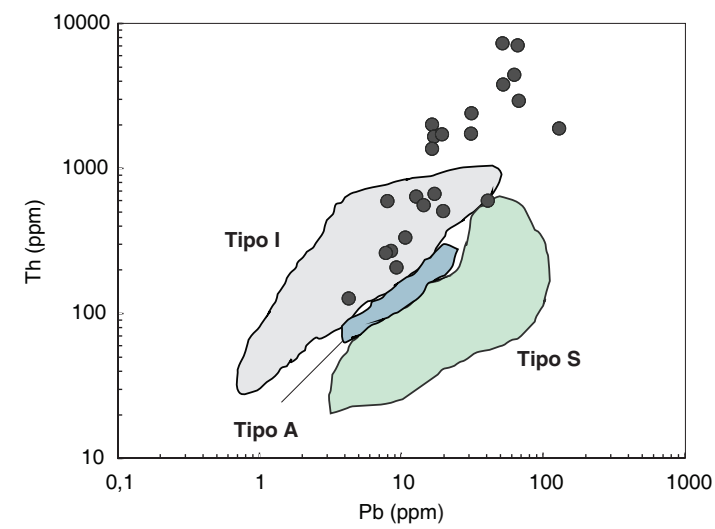

Figura 50. A) Patrones de REE normalizados contra el condrito de McDonough y Sun (1995) de la muestra MIA-638. B) Diagrama Pb vs. Th de Wang et al. (2012) correspondiente a circones de la muestra MIA-638

Los circones de la muestra MIA-638 exhiben razones $\mathrm{Th} / \mathrm{U}$ por encima de 0,4 , siendo la mayor parte próxima a 1 o superior (figura 49), característica de circones ígneos. Los contenidos de los elementos de las tierras raras en los circones de esta muestra se presentan en el anexo 2.2. En términos generales, los patrones de REE son paralelos a subparalelos entre sí (figura 50A), y son parecidos a los patrones de circones ígneos con anomalía positiva de Ce y negativa de Eu, exceptuando los de algunos análisis que cruzan los anteriores y uno que muestra enriquecimiento en LREE. En la figura 50B, usada para inferir la afinidad de los circones con tipo de granitoides, se aprecia que una parte de los resultados grafica en el campo de los granitos tipo I, mientras que otra parte no se ubica en ningún campo específico.

La muestra LMC-075 es del cuerpo principal y fue colectada en la carretera Mogotes-vereda El Gaital, hacia el sector suroccidental del batolito. Los circones son euhedrales prismáticos alargados y cortos, de tonalidad parduzca. Exhiben tamaños de 70 x $200 \mu \mathrm{m}, 90$ x 150 $\mu \mathrm{m}$, principalmente, y en menor cantidad de $50 \times 120$ $\mu \mathrm{m}$. La muestra fue analizada en el Laboratorio de Ablación Láser del Servicio Geológico Colombiano, en Bogotá. En CL, gran parte de los circones exhibe zonación oscilatoria (figura 51).

Los resultados isotópicos se muestran en el anexo 1.3. En esta muestra se descartaron del análisis también los resultados con discordancias inversas menores de $-6 \%$ y con error mayor o igual a $5 \%$. La muestra presenta varios resultados de circones heredados (tabla 12). El resto de datos se agrupan en el límite Triásico-Jurásico y en el Jurásico temprano (figura 52A), entre 220 y 181 Ma, con una edad promedio de $196 \pm 4$ Ma (figura 52B) y un MSWD de 7,2.

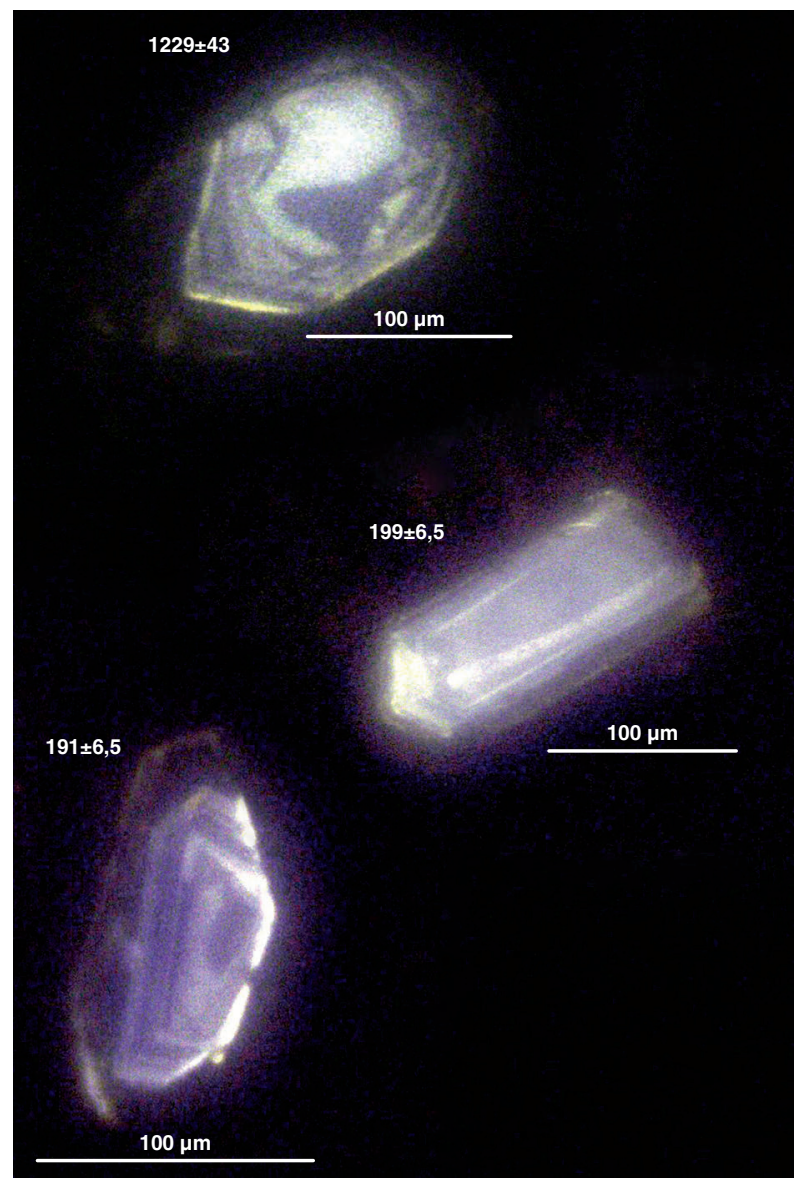

Figura 51. Imágenes de catodoluminiscencia de circones fechados de la muestra LMC-075 

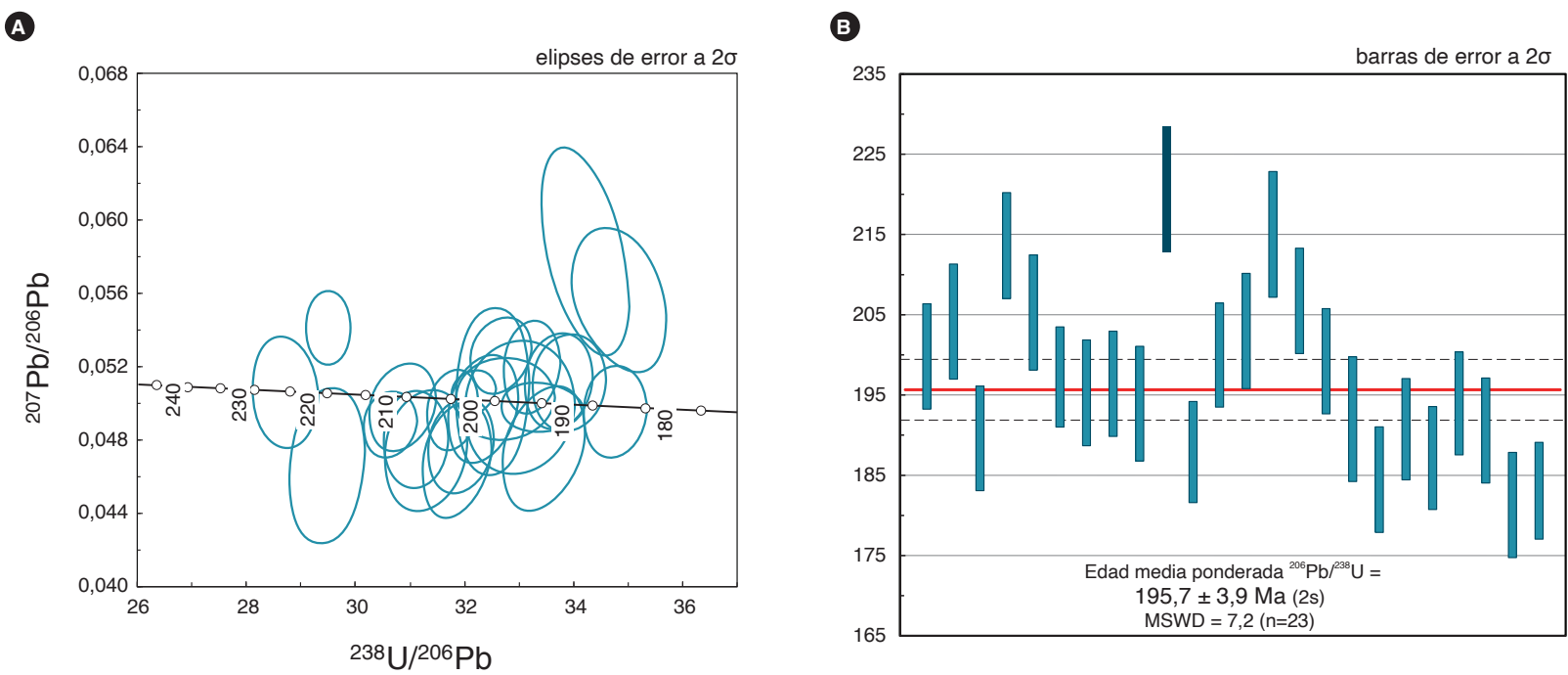

Figura 52. A) Concordia Tera-Wasserburg que muestra los resultados U-Pb en circón de muestra LMC-075. B) Edad media de la muestra

Las razones Th/U de cuatro de los circones heredados son inferiores a 0,3. Los circones con resultados del límite Triásico-Jurásico y del Jurásico temprano exhiben razones Th/U por encima de 0,4 , casi todos próximos a 1 y por encima de 1 (figura 53), razones típicas de circones ígneos.

La muestra AMC-01 62 fue colectada en la carretera San Joaquín-San Cayetano. Los circones son abundantes en la muestra, y se hallan varias poblaciones según las formas. La predominante es entre prismática y acicular con elongación aproximada de 0,27; le sigue la población de cristales achatados largos con elongación de 0,5, y finalmente la población de tallos cortos y largos (long and short stalky). Son limpios, transparentes y de tonalidad rosa pálido. Los tamaños predominantes son de 60 × 220 $\mu \mathrm{m}$. La muestra fue analizada en el Laboratorio de Ablación Láser del Servicio Geológico Colombiano, en Bogotá. En CL, la mayor parte de los circones exhibe zonación oscilatoria (figura 54); algunos presentan núcleos heredados con estructura homogénea y más luminiscente (figura 54). Otros presentan bordes de luminiscencia más baja en comparación con los de las áreas zonadas.

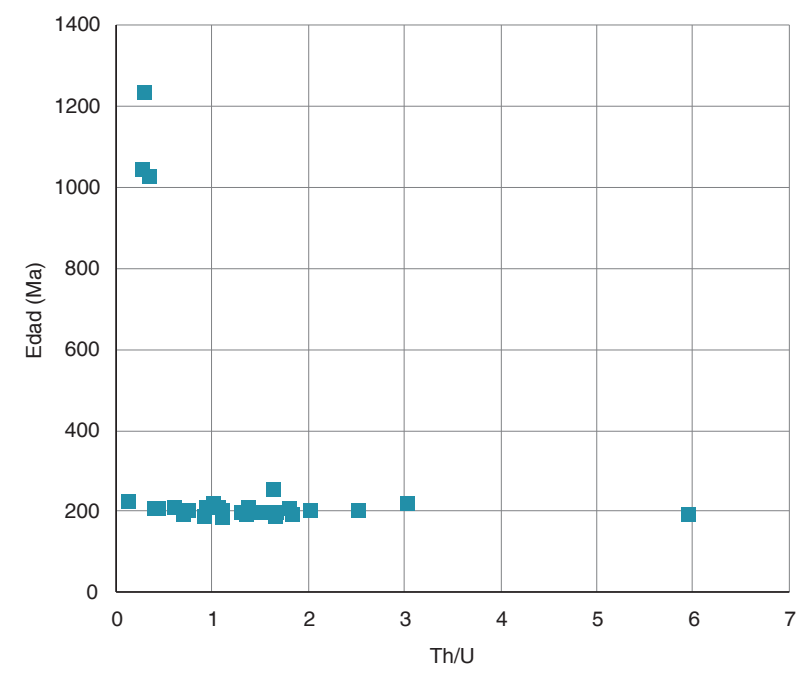

Figura 53. Diagrama de relación Th/U vs. Edad en circones de la muestra LMC-075 


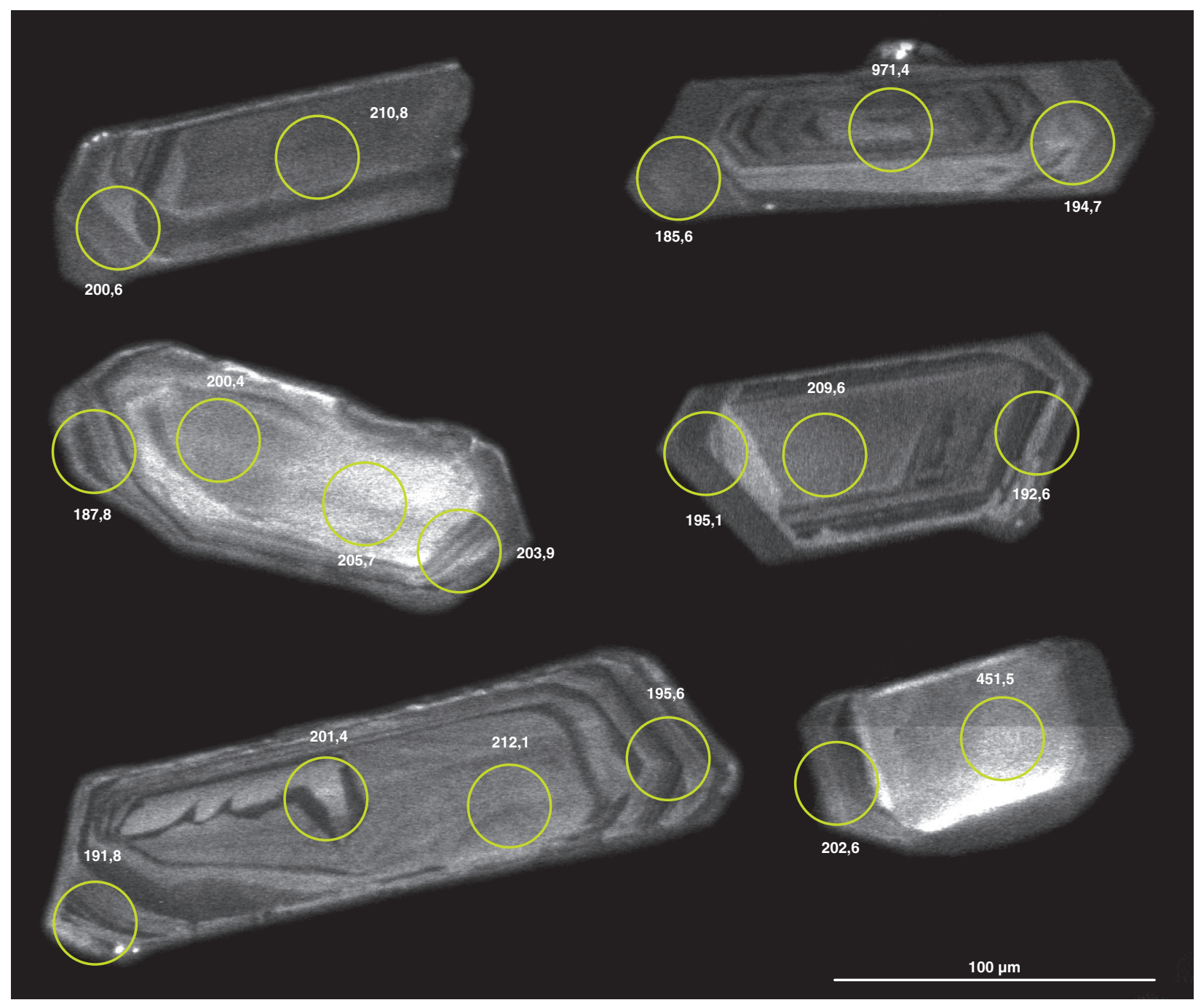

Figura 54. Imágenes de catodoluminiscencia en circones de la muestra AMC-0162 y resultados de edades en varios puntos

Se hicieron medidas en 195 puntos en total. Los resultados están en el anexo 1.4. En la interpretación de esta muestra no se consideraron en los resultados precámbricos con discordancias mayores a 5\% y errores mayores de $9 \%$. También se descartaron de la interpretación los puntos con contenidos de U mayores de 10.000 ppm. Los resultados aceptados se exhiben en la figura 55. Los resultados de herencia se listan en la tabla 12 y se muestran en la figura 56. La muestra contiene algunas herencias del Meso y Neoproterozoico, abundantes he- rencias desde el Ordovícico Tardío hasta el Carbonífero Temprano (Mississipiano), y en menor cantidad herencias del Pérmico hasta el Triásico Medio. En esta muestra, similar a lo observado en otras de monzogranitos, se obtuvieron resultados continuos en un rango amplio de edades, desde 225 hasta $183 \mathrm{Ma}$ (figura 57), la mayor parte concordantes, y dos datos más jóvenes, de 177 y $173 \mathrm{Ma}$, discordantes (figura 57). En general, se aprecia una variación continua de núcleo a borde de edades más antiguas a más jóvenes. 


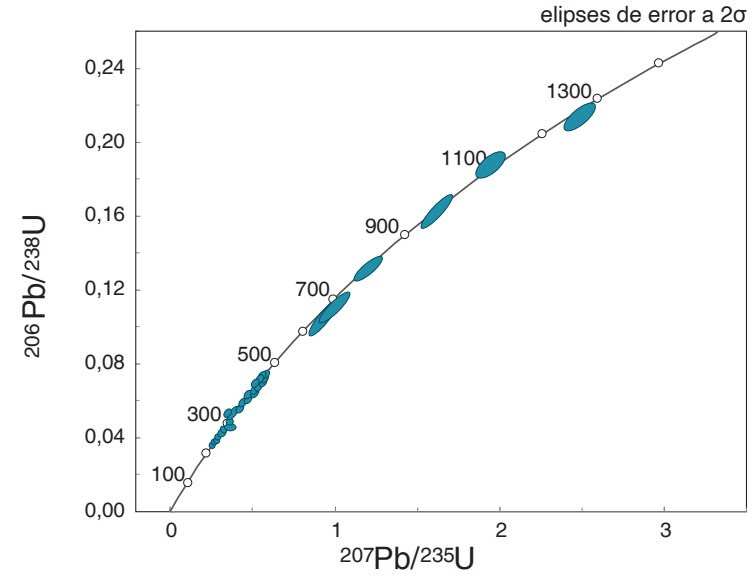

Figura 55. Diagrama de la concordia Wetherill correspondiente a los resultados aceptados de la muestra AMC-0162

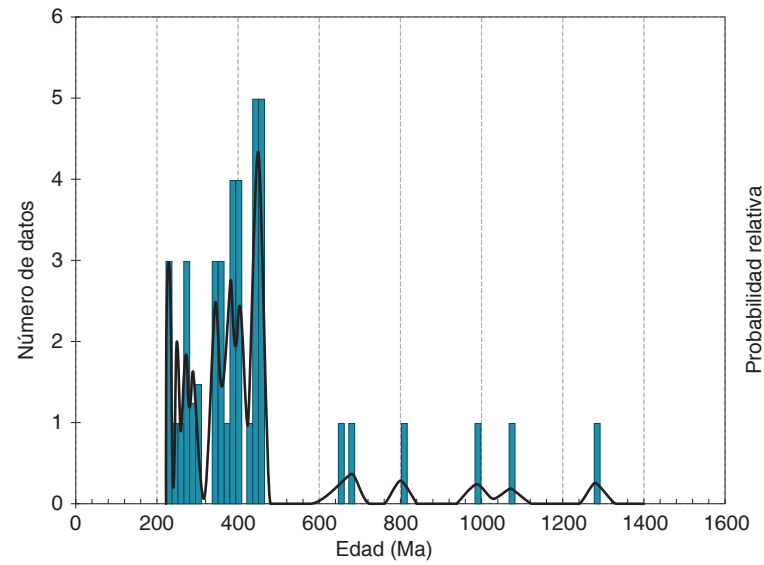

Figura 56. Diagrama de densidad de probabilidad de las edades heredadas correspondiente a la muestra AMC-0162

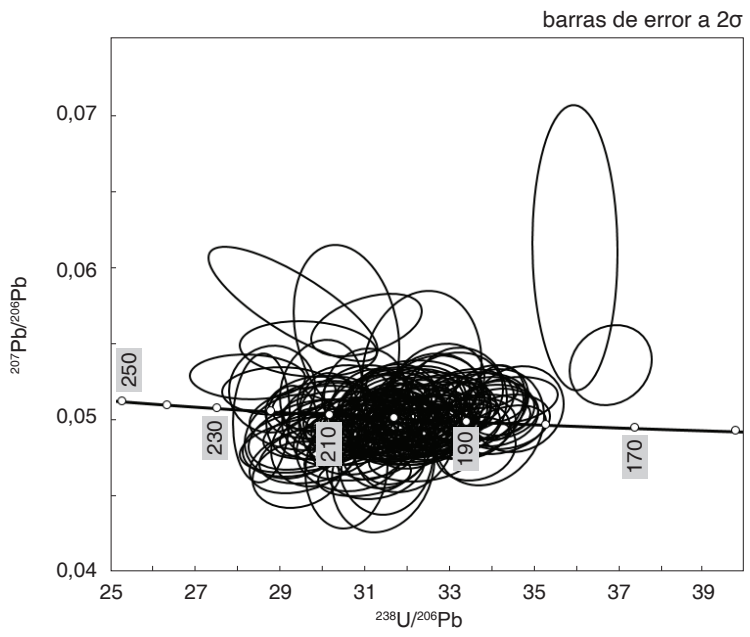

Figura 57. Concordia Tera-Wasserburg con datos de la muestra AMC0162 entre 225 y 183 Ma y dos valores discordantes de 177 y $173 \mathrm{Ma}$
En los granos con edades Triásico-Jurásicas es posible distinguir en las imágenes de CL tres zonas texturales, así: en el centro de cristales, áreas que tienden a ser homogéneas de tonalidad gris, sin zonación reconocible (zona 1); en dirección a los bordes, áreas con zonación donde se aprecia alternancia de tonos de gris (zona 2), casi siempre rodeadas de manera transicional por un borde en ocasiones homogéneo y, en otras, con zonación, y en general de color gris más oscuro (zona 3). La zona 1 se interpreta como antecristales, mientras que la zona 2 corresponde al principal evento de cristalización de circón, y la zona 3 puede representar el evento final de cristalización de la roca o un área donde hubo pérdida de $\mathrm{Pb}$ por metamictización de los bordes del circón.

El análisis del diagrama de densidad de probabilidad (figura 58) sugiere tres grupos de edades, por la presencia de dos picos suaves y un pico bien pronunciado en la curva.

Se obtuvieron tres edades a partir de los tres grupos de zonas identificados en los circones, aunque el límite entre estos no fue absolutamente claro. El primer grupo está conformado por los valores situados entre 222 y $206 \mathrm{Ma}$, que se observan principalmente en centros de cristales donde no hay zonación oscilatoria o en borde de circones con núcleos heredados antiguos. Este grupo tiene una edad promedio de $211 \pm 1 \mathrm{Ma}$ (figura 59A) con un MSWD de 1,4, y correspondería a la edad de antecristales que representarían un primer evento de cristalización del cuerpo o un primer pulso magmático. El segundo grupo estaría representado por los resultados

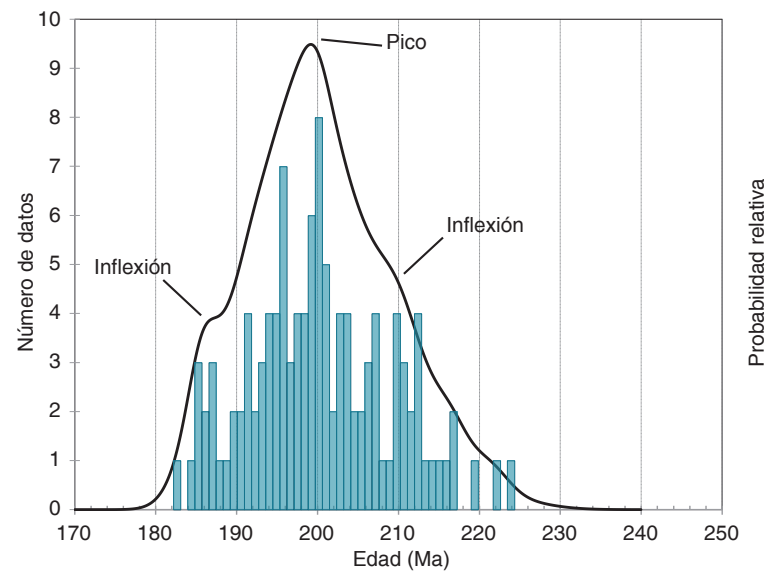

Figura 58. Diagrama de densidad de probabilidad correspondiente a los resultados en circones ígneos del Triásico Tardío-Jurásico Temprano 


\section{A}

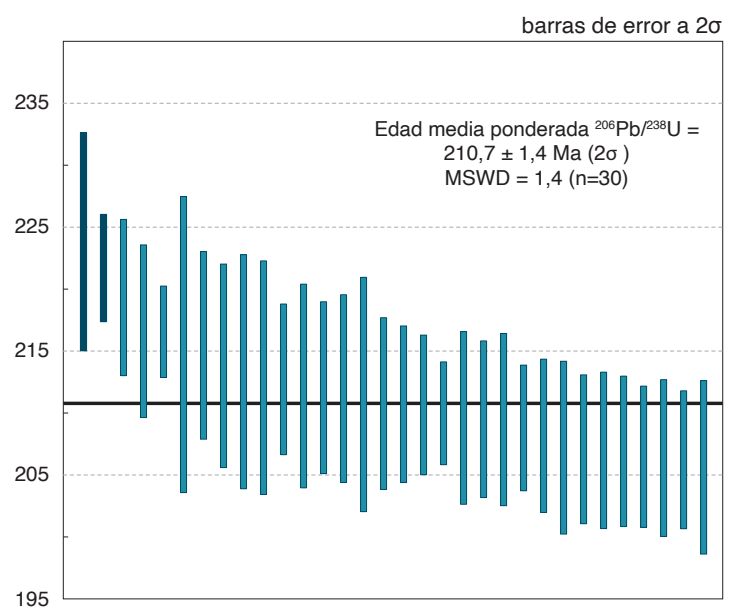

B

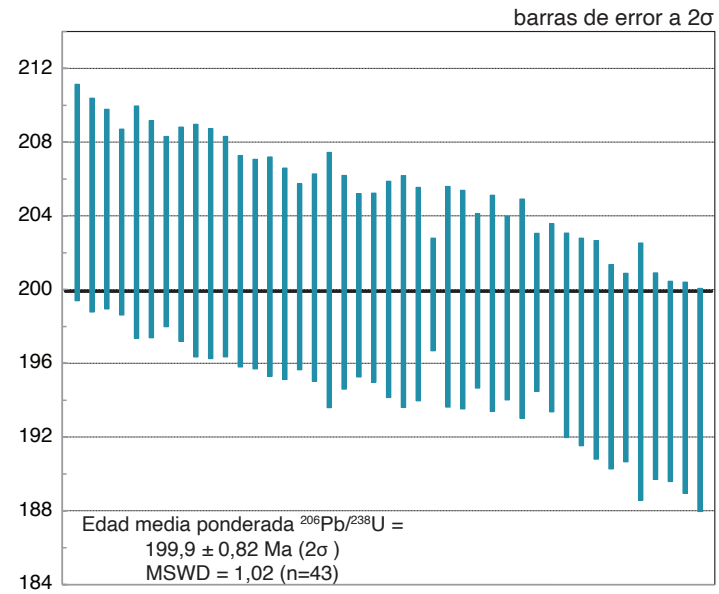

C

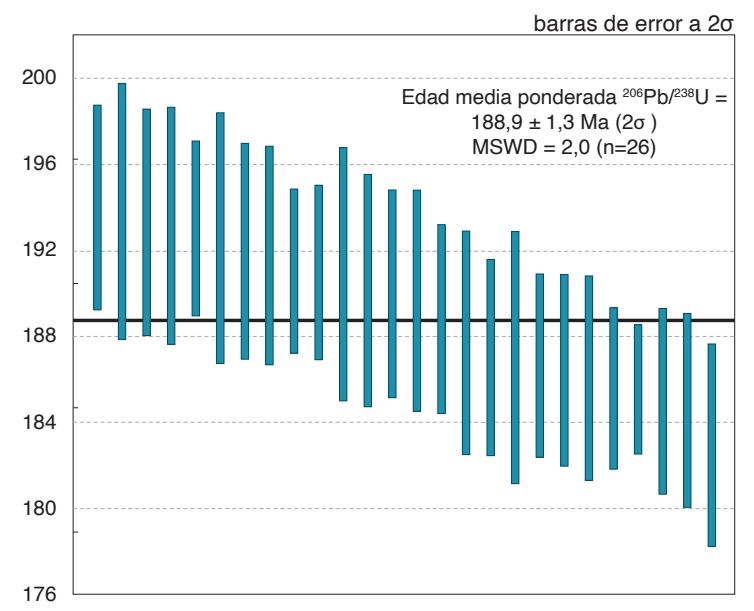

Figura 59. Edades promedio ponderadas obtenidas en las tres zonas identificadas de los circones triásico-jurásicos de las muestra AMC-0162 situados entre 205 y $194 \mathrm{Ma}$, que se hallan en partes con zonación oscilatoria, y su edad promedio es de $200 \pm 1$ Ma (figura 59B), con un MSWD de 1. Esta es la edad del pico principal y es la del principal evento de cristalización. Por último, los resultados entre 194 y 183 , que se hallan en los bordes de los cristales, en áreas con o sin zonación, de luminiscencia más baja, arrojan una edad promedio de $189 \pm 1 \mathrm{Ma}$, con un MSWD de 2 (figura 59C), edad que correspondería al último pulso magmático, o a la cristalización final de la roca o a un evento de pérdida de $\mathrm{Pb}$.

La interpretación de la relación Th/U vs. edad se hizo por grupos, así (figura 60): los cuadros naranja representan circones con edades entre 219 y $206 \mathrm{Ma}$, los círculos representan circones con edades entre 206 y $194 \mathrm{Ma}$, y los triángulos grises representan circones con edades entre 194 y 183 Ma. Esta relación permite interpretar que los tres grupos tienen razones $\mathrm{Th} / \mathrm{U}$ por debajo de 1 , zona en la que no hay diferencia entre grupos. Los grupos 1 y 2 tienen, además, razones entre 1,5 y 2,5; el grupo 2 tiene las razones más altas, pues llega casi a 4, y el grupo 3, las razones más bajas, todas por debajo de 1,5.

La muestra GZ-6831 es del cuerpo principal, pero de la zona donde predominan granodioritas y cuarzomonzodioritas, y fue colectada en la carretera San Joaquín-Las Tapias-El Carmen, en el sector suroriental del cuerpo. Los circones son euhedrales prismáticos alargados, transparentes, de tonalidad rosa pálido. Predominan los cristales con tamaños que rondan los 80 × 260 $\mu \mathrm{m}$, y en menor proporción se encuentran más finos, de

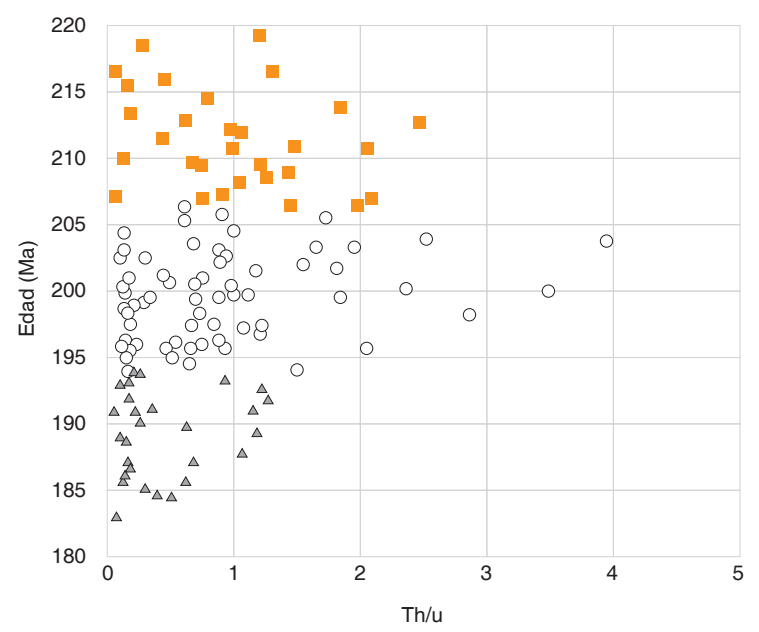

Figura 60. Relaciones Th/U vs. edad en los circones de la muestra AMC0162 con edades entre 219 y $183 \mathrm{Ma}$ 
$60 \times 145 \mu \mathrm{m}$. La muestra fue analizada en el Laboratorio de Ablación Láser del Servicio Geológico Colombiano, en Bogotá. Los resultados se encuentran en el anexo 1.5. En CL, la mayor parte de los circones exhibe zonación oscilatoria (figura 61).

En la interpretación de las dataciones se descartaron aquellos resultados con porcentajes de discordancia mayores del 10\%. La mayor parte de los datos concordantes pueden datarse entre 204 y $185 \mathrm{Ma}$ (figura 62A). Los análisis arrojaron una edad media de $194 \pm 1 \mathrm{Ma}$ (figura 62B), con una MSWD de 1,9, que corresponde a la edad de cristalización ígnea.

Las razones $\mathrm{Th} / \mathrm{U}$ de los circones con edades menores de 220 Ma son mayores de 0,5 , casi todos cercanos y superiores a 1 (figura 63).

A

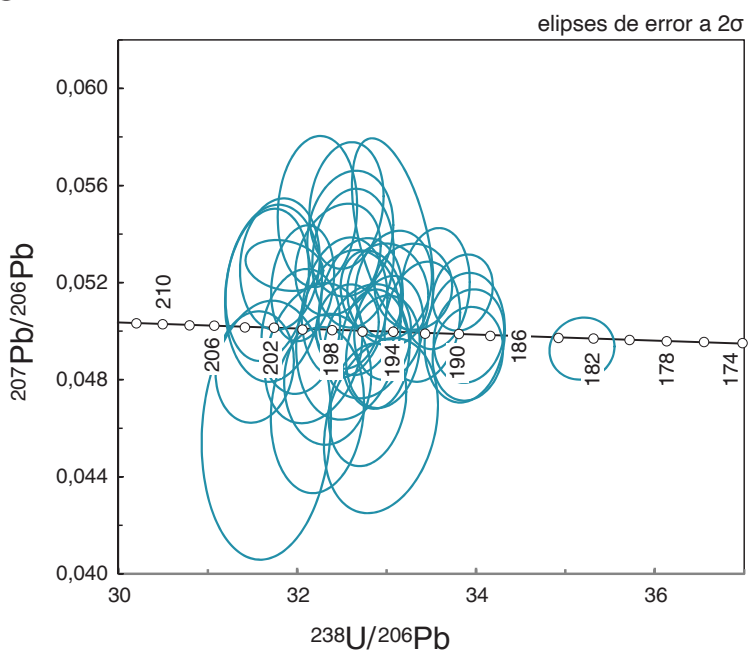

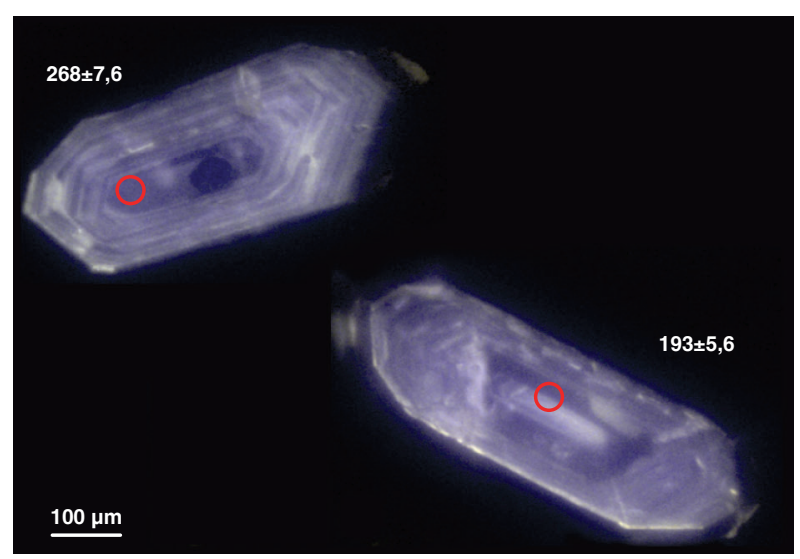

Figura 61. Imágenes de catodoluminiscencia de circones fechados de la muestra GZ-6831

B

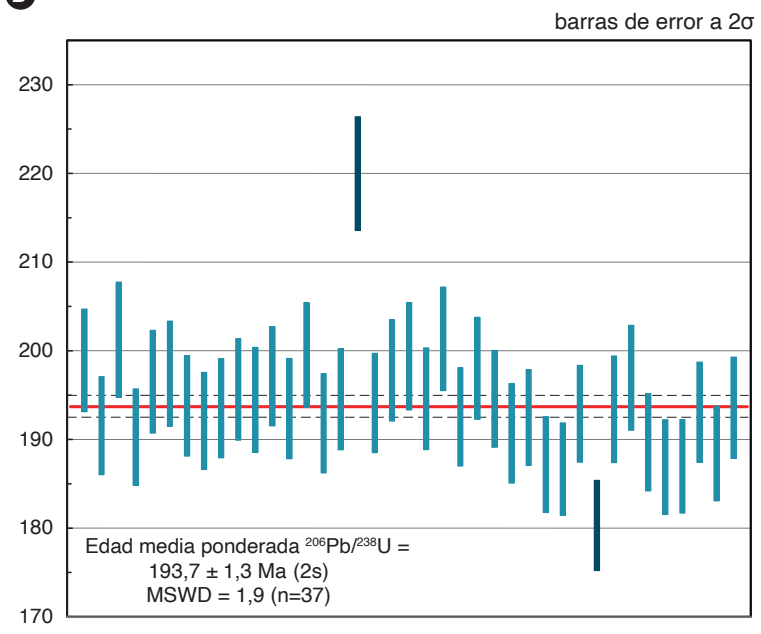

Figura 62. Resultados geocronológicos de la muestra GZ-6831. A) Concordia Tera-Wasserburg que muestra los resultados U-Pb en circón. B) Edad media de la muestra GZ-6831

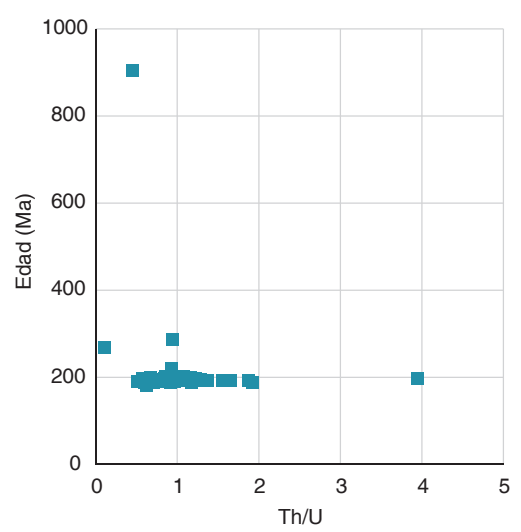

Figura 63. Diagrama de relación Th/U vs. edad correspondiente a circones de la muestra GZ-6831 


\subsection{Edades en cuerpos menores y diques}

La muestra MIA-636 es de un cuerpo menor diferente del Batolito de Mogotes y fue colectada en la vía Aratoca-desvío La Palma, en el sector de Tempranito, en el lado oriental de la porción septentrional del batolito. Los circones de esta muestra son euhedrales prismáticos cortos y largos, hasta tabulares, con la superficie impregnada de óxidos y, en general, muy fracturados. Varían de incoloros a café pálido. Los circones tienen tamaños de 70 x $150 \mu \mathrm{m}, 40$ × $85 \mu \mathrm{m}$, y escasos cristales de mayor tamaño que pueden alcanzar hasta 85 x 280 $\mu \mathrm{m}$. La muestra fue analizada en el Laboratorio de Estudios Isotópicos del Centro de Geociencias de la Universidad Autónoma de México. Los resultados isotópicos se presentan en el anexo 1.6. En imágenes de catodoluminiscencia (CL) se insinúan zonaciones en los circones que van desde sectorial a oscilatoria (figura 64).

(A)

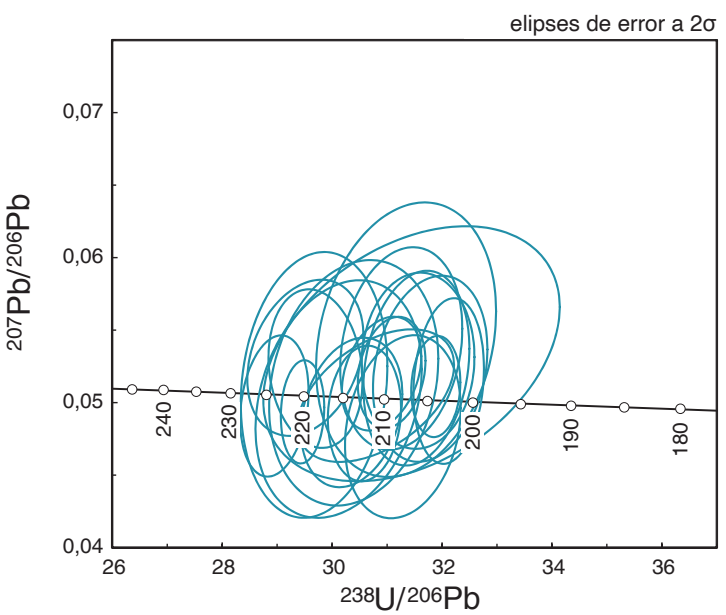

Los resultados concordantes se agrupan entre $220 \mathrm{y}$ $195 \mathrm{Ma}$ (figura 65A), que arrojan una edad promedio de $205 \pm 3$ Ma (figura 65B) y un MSWD de 13, interpretada como la edad de cristalización. Las razones $\mathrm{Th} / \mathrm{U}$ en general son mayores de 0,5 y están alrededor de 1 (figura 66).

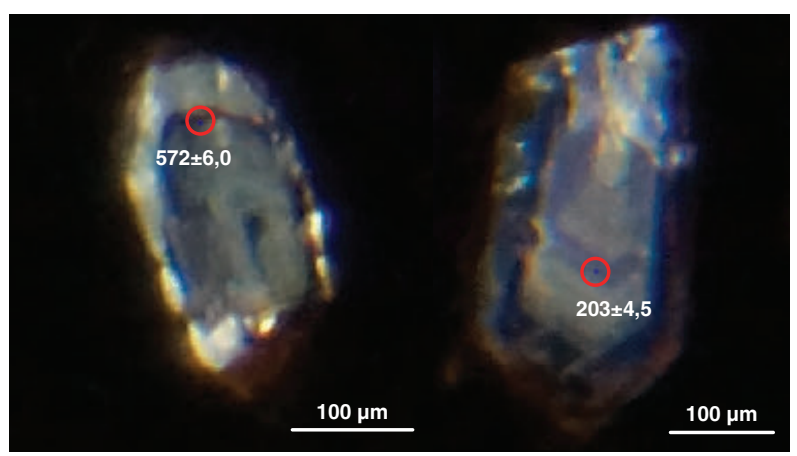

Figura 64. Imágenes de catodoluminiscencia de circones fechados en la muestra MIA-636

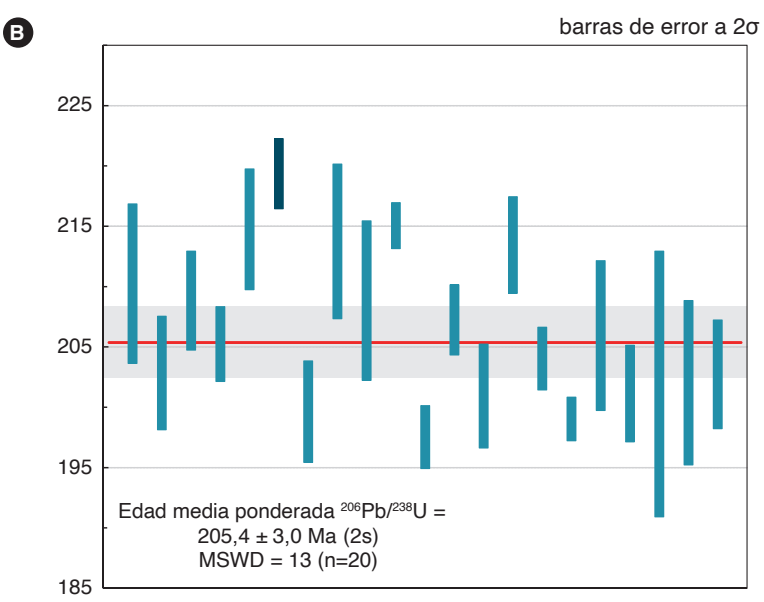

Figura 65. Resultados geocronológicos de la muestra MIA-636. A) Concordia Tera-Wasserburg que muestra los resultados U-Pb en circón. B) Edad media de la muestra MIA-636

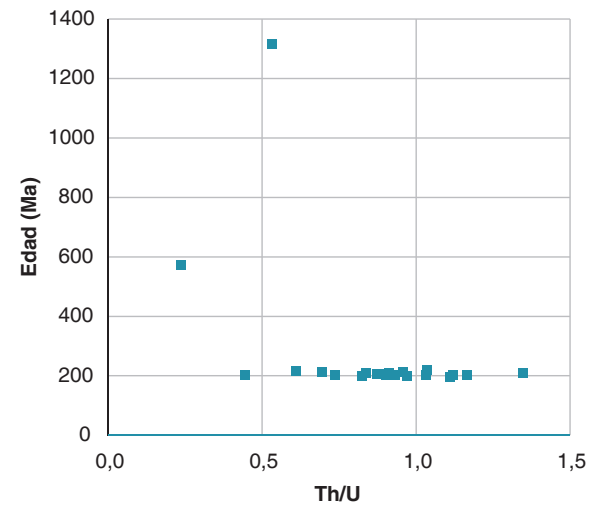

Figura 66. Diagrama de relación Th/U vs. edad en circones de la muestra MIA-636 
Los resultados de elementos de las tierras raras en circones se muestran en el anexo 2.3. La mayor parte de los patrones de REE son paralelos a subparalelos (figura 67A), semejantes a los de circones ígneos con anomalía positiva de Ce y negativa de Eu. Algunos son más enriquecidos en LREE y muestran un patrón más plano en este sector de REE, que puede deberse al análisis de mi-

A

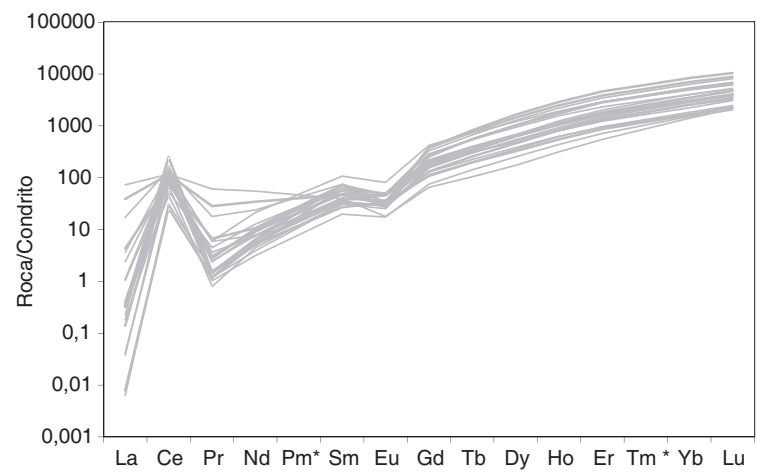

croinclusiones de un mineral rico en LREE, posiblemente monacita. Hay un patrón que muestra una anomalía negativa de Eu más pronunciada, y corresponde al del circón heredado de 1.300 Ma. En el diagrama de Wang et al. (2012), casi todos los análisis de los circones grafican en el campo de los granitos tipo I (figura 67B).

B

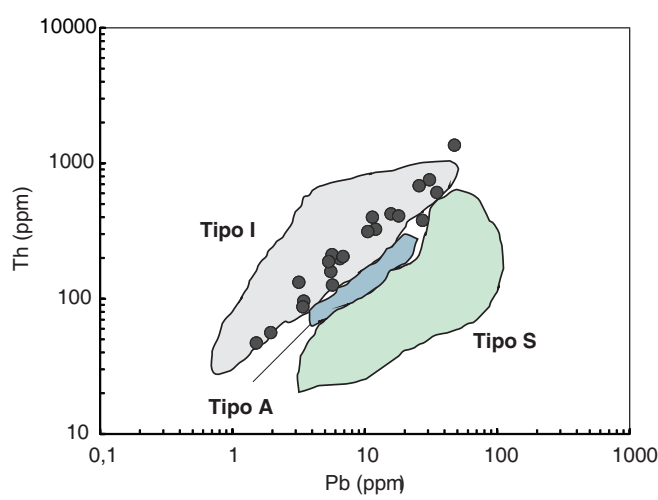

Figura 67. A) Patrones de REE normalizados contra el condrito de McDonough y Sun (1995) de circones de la muestra MIA-636). B) Diagrama Pb vs. Th de Wang et al. (2012) correspondiente a circones de la muestra MIA-636

La muestra AMC-0144 también fue interpretada como perteneciente a un cuerpo menor del Batolito de Mogotes. La muestra fue colectada en la vía San Joaquín-Onzaga, sector de Los Trapiches, en la porción suroccidental del cuerpo. Los circones de la muestra son euhedrales prismáticos bipiramidales y aciculares, transparentes e incoloros. Algunos tienen finas inclusiones y/o impregnaciones de opacos. Los tamaños predo- minantes son de 130 x $210 \mu \mathrm{m}$ y 55 x $280 \mu \mathrm{m}$, y en menor cantidad de 45 × $90 \mu \mathrm{m}$ a 70 x $145 \mu \mathrm{m}$. La muestra fue analizada en el Laboratorio de Estudios Isotópicos del Centro de Geociencias de la Universidad Autónoma de México. Los resultados isotópicos se pueden consultar en el anexo 1.7. En imágenes de catodoluminiscencia (CL), los circones presentan zonación que va de oscilatoria a bandeada (figura 68).

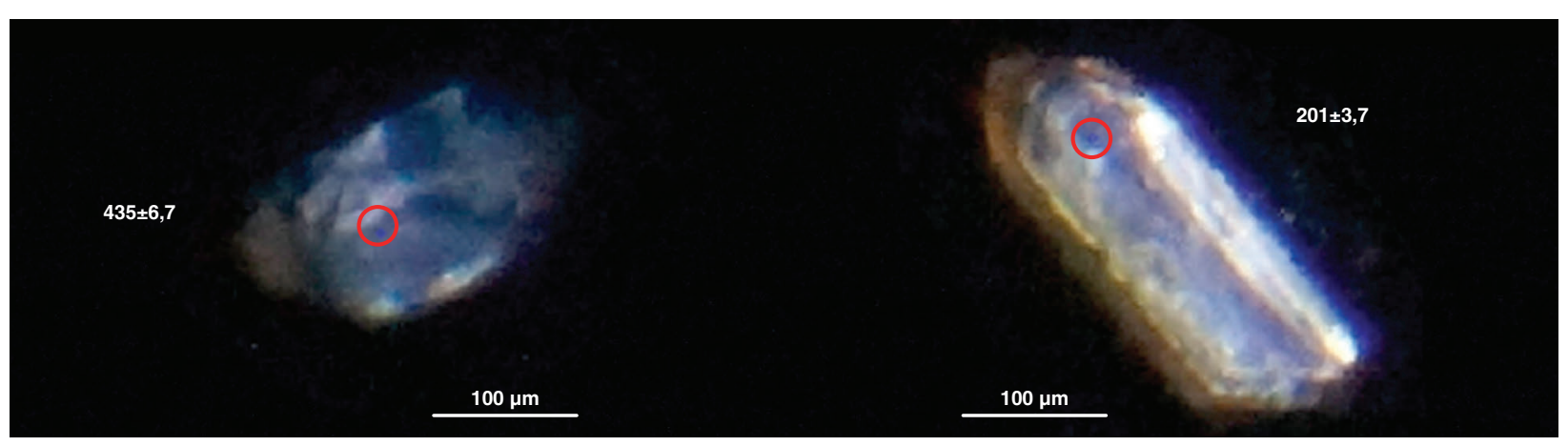

Figura 68. Imágenes de catodoluminiscencia de circones fechados de la muestra AMC-0144 
Los resultados concordantes se agrupan entre 210 y 195 Ma (figura 69A). La edad promedio es de $202 \pm 2$ Ma (figura 69), con un MSWD de 4,6. Las razones Th/U están por encima de 0,5 , y la mayor parte próxima a 1 y por encima de 1 (figura 70), lo que sugiere la naturaleza ígnea de los circones. Los resultados de elementos

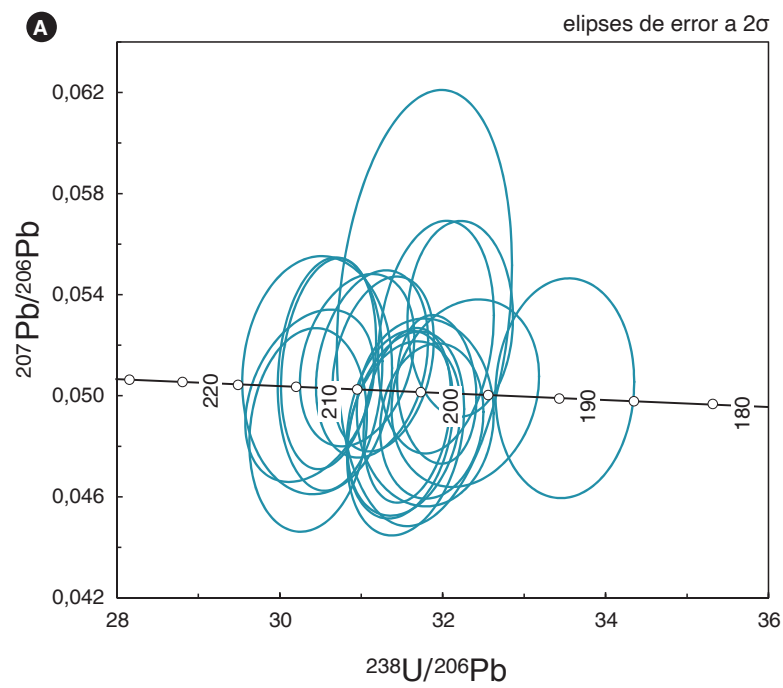

de las tierras raras en circones se presentan en el anexo 2.4. Los patrones de REE también son parecidos a los de circones ígneos con anomalía positiva de Ce y negativa de Eu (figura 71A), exceptuando una muestra que exhibe enriquecimiento en LREE. Hay algunas muestras que presentan bajísimos contenidos de La.

\section{B}

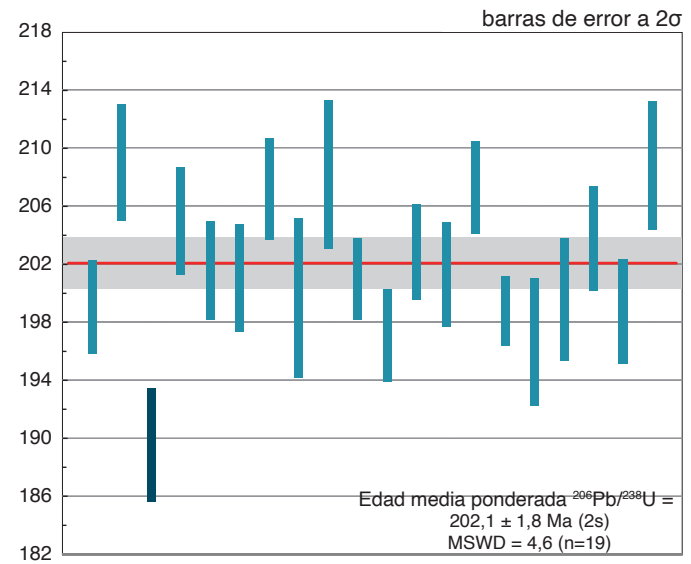

Figura 69. Resultados geocronológicos de la muestra AMC-0144. A) Concordia Tera-Wasserburg que muestra los resultados U-Pb en circón. B) Edad media de la muestra AMC-0144

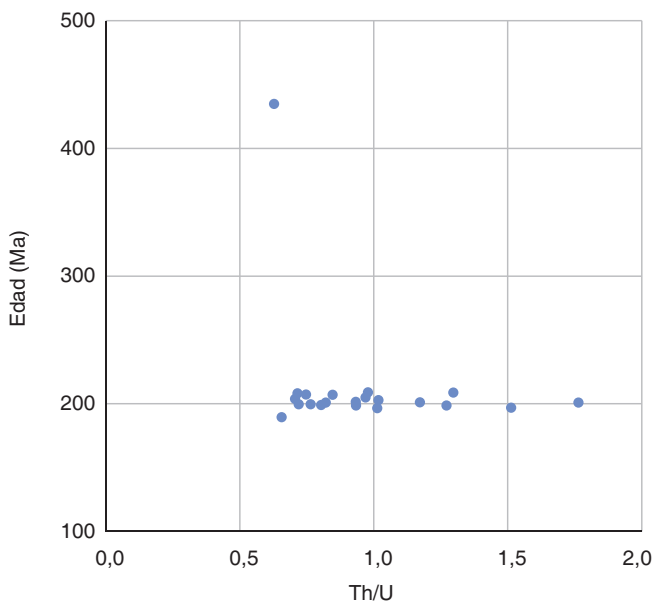

Figura 70. Diagrama de relación Th/U vs. edad en circones de la muestra AMC-0144 

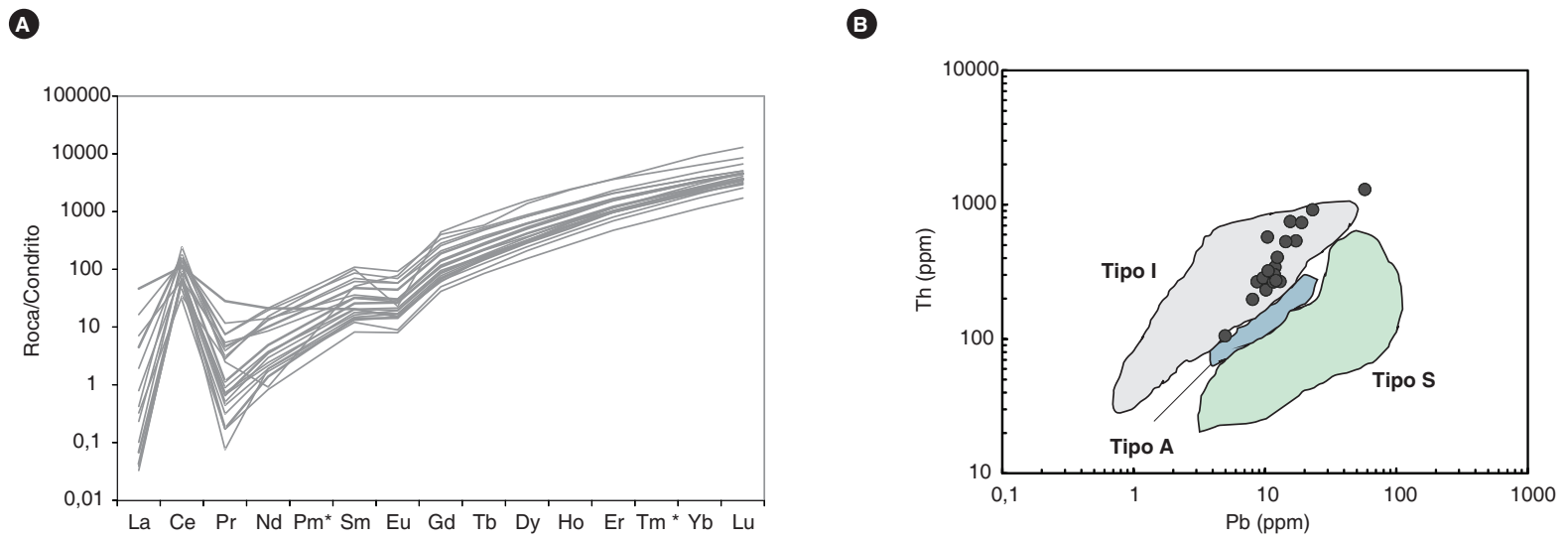

Figura 71. A) Patrones de REE normalizados contra el condrito de McDonough y Sun (1995). B) Diagrama Pb vs. Th de Wang et al. (2012) correspondiente a circones de la muestra AMC-0144

La muestra LMC-071 es un dique de cuarzolatita en límite con latita, según clasificación petrográfica, con fuerte alteración hidrotermal, que fue colectado en la carretera Aratoca-El Uvo-Alto Los Machacadores, en la porción occidental del batolito, un poco hacia la parte norte. Los circones de esta muestra son euhedrales prismáticos, alargados, de tonalidad parduzca, con algunas fracturas internas. Su tamaño predominante es de 40-60 x $140 \mu \mathrm{m}$, y en menor cantidad de 38 x $95 \mu \mathrm{m}$. La muestra fue analizada en el Laboratorio de Ablación Láser del Servicio Geológico Colombiano, en Bogotá. Los resultados isotópicos se encuentran en el anexo 1.8. No se dispone de imágenes de catodoluminiscencia de los circones de esta muestra. Dado que la mayor parte de los datos presentan discordancias muy elevadas, para la interpretación se consideraron aquellos con discordancias menores al 50\%, que al dibujarlos en el gráfico de las concordias resultaron discordantes, exceptuando dos circones heredados. Esta discordancia puede deberse a pérdida de $\mathrm{Pb}$ o entrada de $\mathrm{Pb}$ común al sistema. Los contenidos de $\mathrm{U}$ en casi todos los puntos analizados son muy altos, por encima de 2.700 ppm, y en el gráfico de U vs. edad (figura 72) se ve una tendencia de correlación en la que los circones con más altos contenidos de U son los que arrojan edades más jóvenes. Por los altos contenidos de $\mathrm{U}$, que probablemente dañaron la estructura del mineral y provocaron la pérdida de $\mathrm{Pb}$ y la entrada de contaminantes con $\mathrm{Pb}$ común, se concluye que los circones de esta muestra son metamícticos y no son apropiados para obtener una edad de cristalización de la muestra.

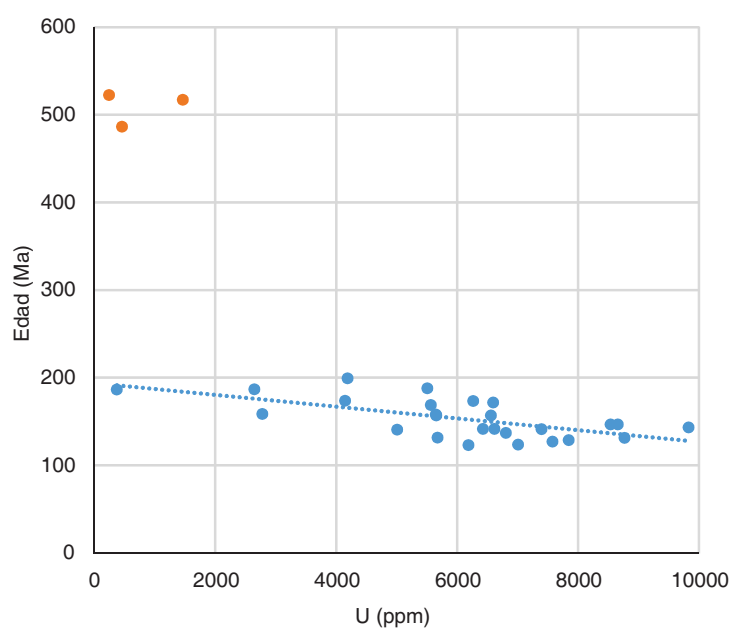

Figura 72. Diagrama U vs. edad correspondiente a los resultados en circones de la muestra LMC-071 
El rango de edades, excluyendo los heredados, varía entre 122 y $199 \mathrm{Ma}$ (no tiene significado geológico). Si se considera que las edades más antiguas, es decir, las que están alrededor de los $200 \mathrm{Ma}$, son las que menos $\mathrm{Pb}$ perdieron, y gráficamente se hace una línea que pase en medio de la nube de esos puntos discordantes, y esta línea se prolonga hasta que intercepte la curva de la discordia, se observa que la intercepción está entre 190 y $200 \mathrm{Ma}$ (figura 73), valores coincidentes en términos

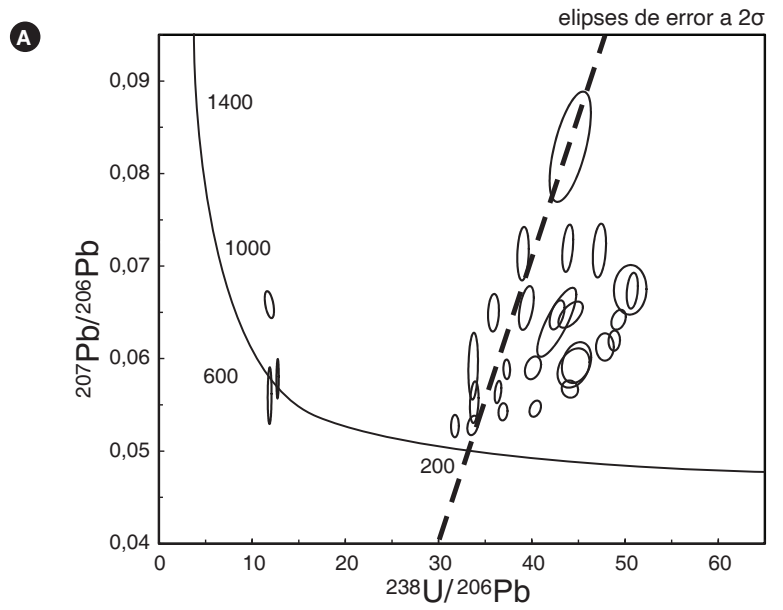

amplios con el rango de edades obtenido en las otras muestras del cuerpo principal. Es muy importante anotar que esta información solo da una idea de la posible edad de la muestra, pero no representa edades absolutas de la misma, y por lo tanto esta edad no se puede interpretar como la edad de cristalización de la roca, porque los circones están muy alterados y los resultados fueron muy discordantes.

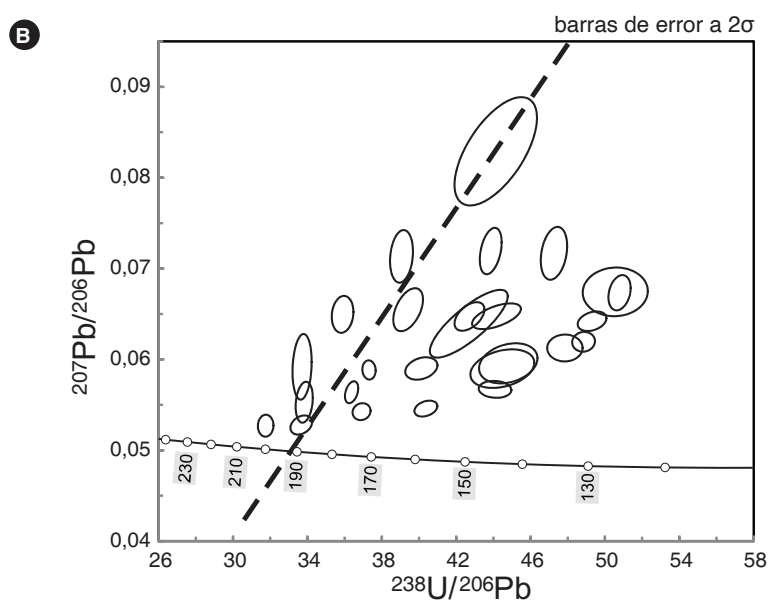

Figura 73. Diagramas Tera-Wasserburg correspondientes a la muestra LMC-071

La muestra TCR-380 corresponde a un dique dentro de monzogranito. El dique es de color oscuro, por lo que se interpreta como de composición máfica, y por encontrarse saprolitizado no se le hizo sección delgada. La muestra fue colectada en la carretera Mogotes-vereda El Gaital. Los circones de la muestra son cristales euhedrales a subhedrales; predominan los de forma prismática corta sobre los de forma larga, algunos muy redondea- dos; hay incoloros y algunos con tonalidad lila, casi todos con inclusiones. Presentan tamaños entre 70 y 200 micrómetros. La muestra fue analizada en el Laboratorio de Ablación Láser del Servicio Geológico Colombiano, en Bogotá. Los resultados isotópicos se exponen en el anexo 1.9. En las imágenes de catodoluminiscencia algunos exhiben zonación oscilatoria, y otros, en parches (figura 74).

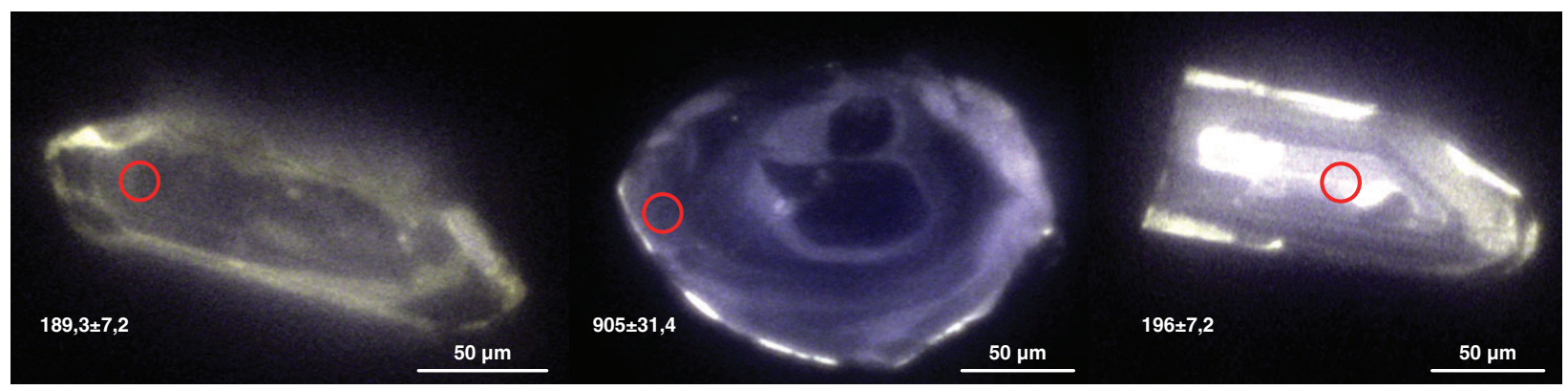

Figura 74. Imágenes de catodoluminiscencia de circones fechados de la muestra TCR-380 
Después de descartar los resultados con porcentajes de discordancia mayores del 10\% se observa que hay un grupo representativo cuyas edades están entre los 200 y $190 \mathrm{Ma}$, varias edades heredadas, algunas concordantes y otras discordantes, desde 215 hasta 924 Ma, y dos resultados con edades jóvenes de alrededor de $75 \mathrm{Ma}$, uno concordante y el otro discordante. El significado de estos dos resultados más jóvenes no se conoce. La interpretación de la edad de la muestra se basa en el grupo de datos que varían entre 200 y 190 Ma. En el diagrama de la concordia Tera-Wasserburg se aprecia que varios son discordantes y que existe una agrupación a 200 Ma y otra a $190 \mathrm{Ma}$ (figura 75A); sin embargo, como no hay criterios que permitan decir que corresponden a dos poblaciones diferentes, se consideran todos en conjunto, y así se obtiene una edad media de $191 \pm 3$ Ma y un MSWD de 4,2 (figura 75B), que se interpreta como la edad de cristalización de esta roca.

Las razones $\mathrm{Th} / \mathrm{U}$ de los circones heredados muestran valores próximos a 0,1 y valores próximos, pero menores de 1 (figura 76), lo que sugiere que hay circones heredados tanto ígneos como metamórficos. Estas razones, en gran parte de los circones considerados en la edad, son mayores de $1 \mathrm{y}$, exceptuando un resultado, todos son mayores de 0,5. Este caso sugiere que se trata de circones ígneos.
A

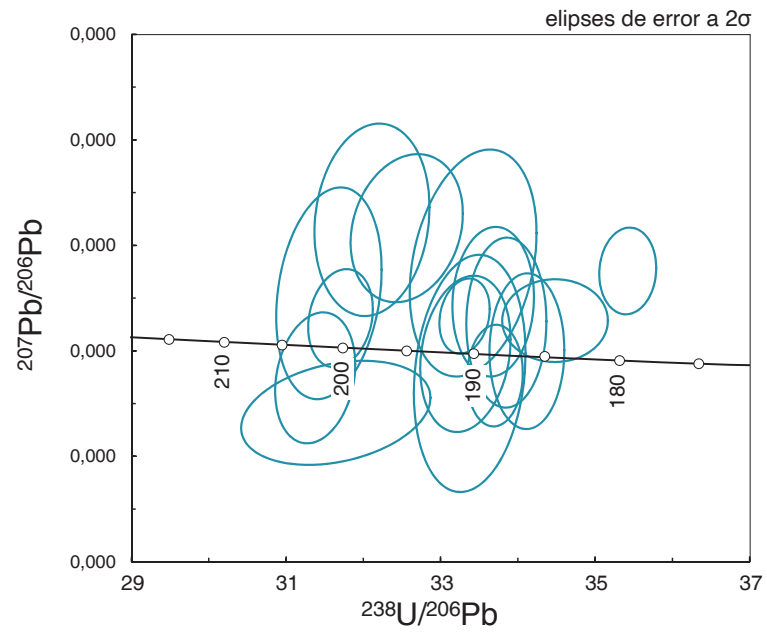

B

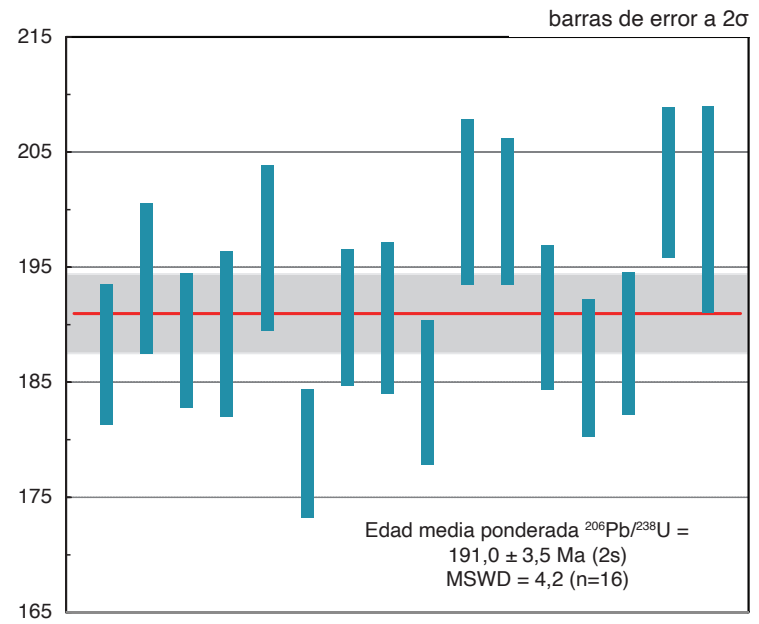

Figura 75. A) Concordia Tera-Wasserburg que muestra los resultados U-Pb en circón que se interpretan como los de cristalización. B) Edad media de la muestra TCR-380

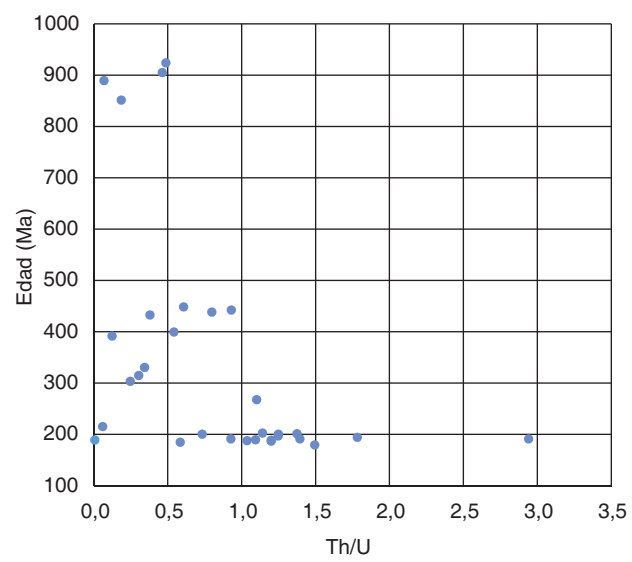

Figura 76. Diagrama de relación Th/U vs. edad en circones de la muestra TCR-380 
La muestra AMC-0136A es de un dique de microtonalita alterada dentro de un monzogranito, encontrado en el sector norte del batolito. Los circones en la muestra son escasos y se caracterizan por aparecer en cristales euhedrales prismáticos cortos, de transparentes - con tonalidad rosa tenue - a translúcidos con tonalidad - amarillenta-, por tinción con óxidos de hierro; hay varios que corresponden a fragmentos de cristales. Algunos tienen inclusiones de opacos; otros cuantos, fracturas internas. Los tamaños varían desde $60 \times 110 \mu \mathrm{m}$, pasando por $90 \times 150 \mu \mathrm{m}$, hasta $100 \times 200 \mu \mathrm{m}$. La muestra fue analizada en el Laboratorio de Ablación Láser del Servicio Geológico Colombiano, en Bogotá. Se hicieron veintiséis ablaciones. En CL, casi todos muestran una zonación irregular y pocos exhiben zonación concéntrica. En general, tienen una luminiscencia baja (figura 77).

Los resultados se exponen en el anexo 1.10; los datos de herencia están resumidos en la tabla 12 . La mayor parte de los resultados se sitúan entre 114 y 94 Ma (figura 78A), de los cuales trece datos arrojan una edad promedio de $108 \pm 2$ Ma y un MSWD de 4,1 (figura 78B), que se interpreta como la edad de cristalización de la muestra. Las razones $\mathrm{Th} / \mathrm{U}$ correspondientes a los resultados cretácicos son en general mayores de 0,2, y predominan los datos entre 0,2 y 0,7 (figura 79).

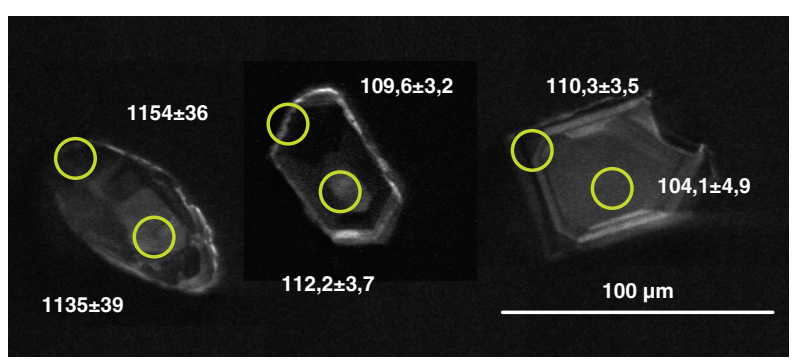

Figura 77. Imágenes de catodoluminiscencia de circones fechados de la muestra AMC-0136A
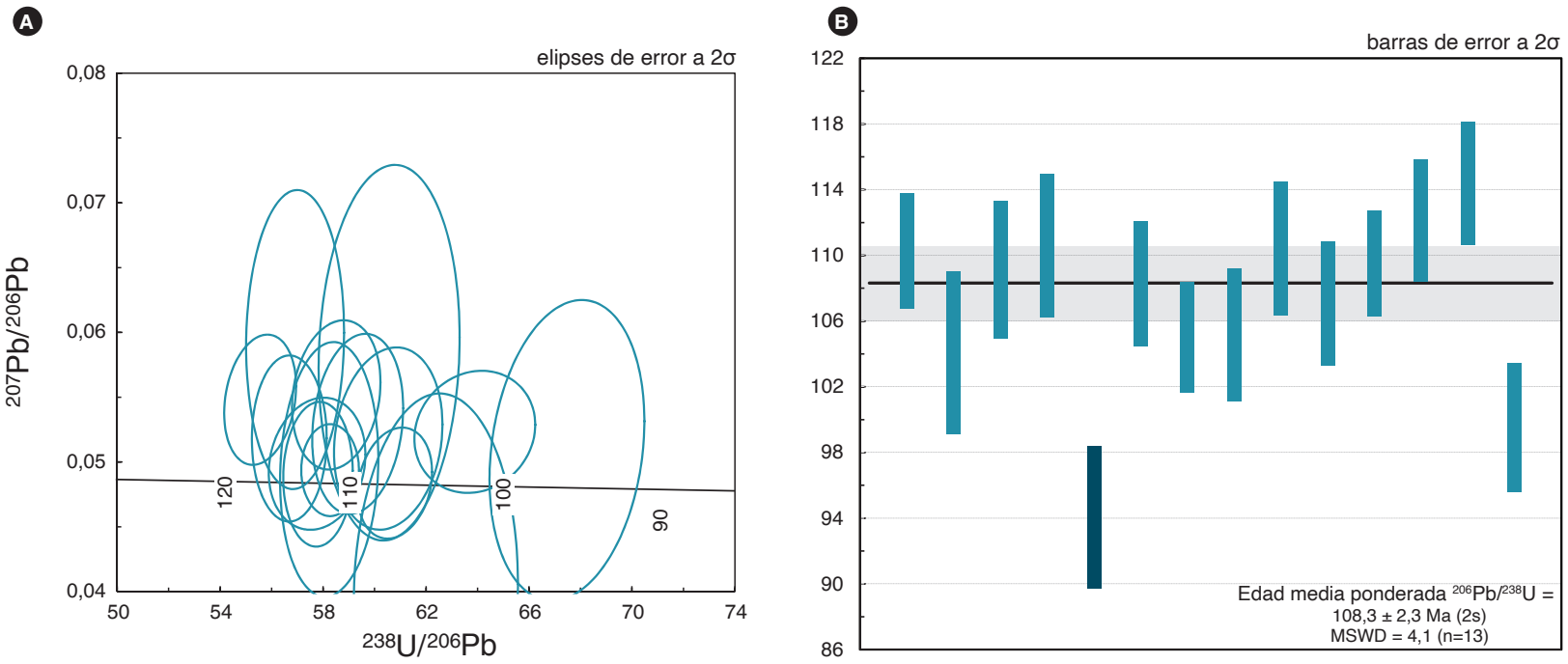

Figura 78. Resultados geocronológicos de la muestra AMC-0136A. A) Concordia Tera-Wasserburg que muestra los resultados U-Pb en circón. B) Edad media de la muestra AMC-0136A 


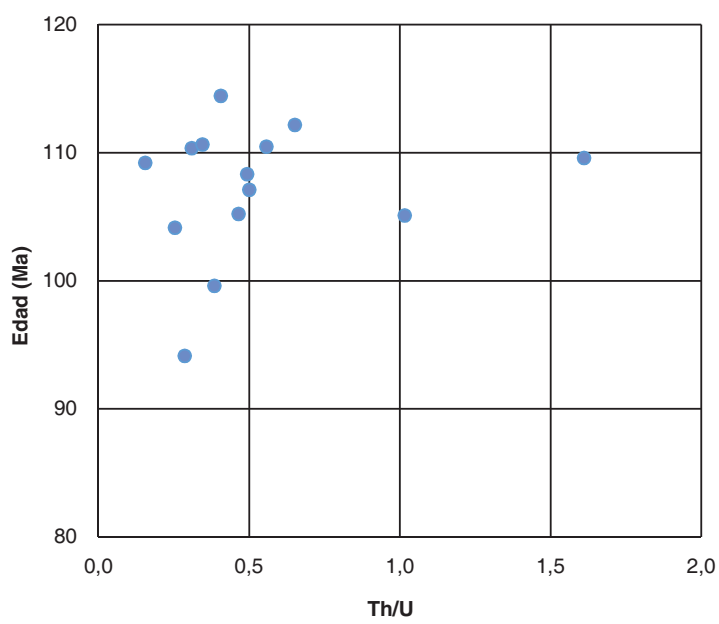

Figura 79. Diagrama de relación Th/U vs. Edad en circones de la muestra AMC-0136A

La muestra GZ-6829B corresponde a un dique de sienogranito colectado en la carretera San Joaquín-Tapias, intruido en un monzogranito con hornblenda o en una granodiorita.

Los circones de la muestra son euhedrales prismáticos cortos, transparentes, con tonalidad rosa tenue. Algunos tienen inclusiones de finas agujas y otras que parecen fluidas, y algunos tienen fracturas internas. Su tamaño varía desde $50 \times 60 \mu \mathrm{m}$ hasta $100 \times 180 \mu \mathrm{m}$, si bien predominan los de $70 \times 120 \mu \mathrm{m}$. La imagen de catodoluminiscencia no es buena, pero da para observar que los circones muestran zonas irregulares y pocos exhiben zonación oscilatoria en sus bordes.

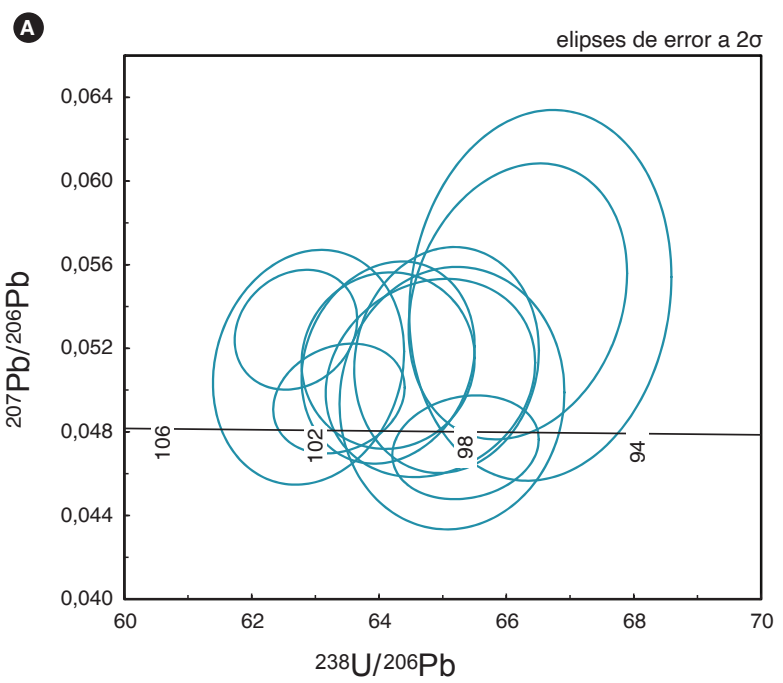

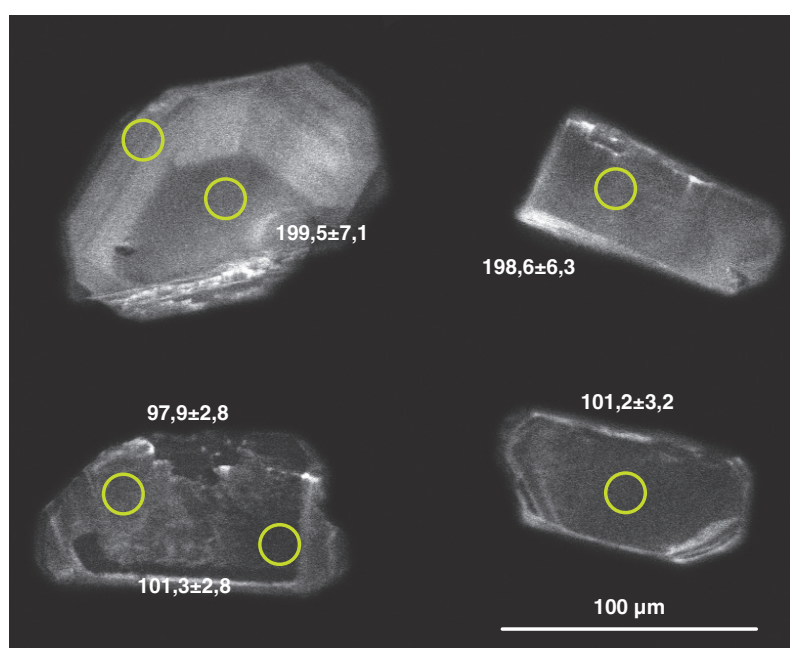

Figura 80. Imágenes de catodoluminiscencia de circones fechados de la muestra GZ-6829B

La muestra fue analizada en el Laboratorio de Ablación Láser del Servicio Geológico Colombiano, en Bogotá. Se hicieron un total de 31 ablaciones. Los resultados se exponen en el anexo 1.11 ; los datos de herencia están resumidos en la tabla 12 . Se observan valores de edades heredadas Triásico-Jurásicas y valores concordantes cretácicos (figura 81 A) que arrojaron una edad promedio de $99 \pm 2$ Ma (figura 81B) y un MSWD de 1,6, que se interpreta como la edad de cristalización. Las razones Th/U varían entre 0,2 y 0,5 en los circones cretácicos, y por encima de 0,5 , principalmente entre 1,5 y 2 , en los circones heredados triásico-jurásicos (figura 82).

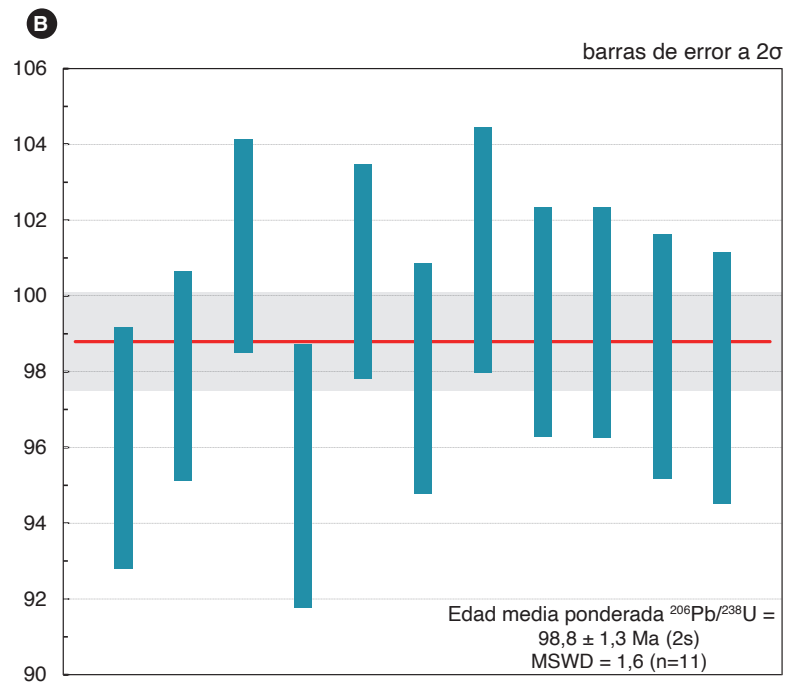

Figura 81. Resultados geocronológicos de la muestra GZ-6829B. A) Concordia Tera-Wasserburg que muestra los resultados U-Pb en circón. B) Edad media de la muestra GZ-6829B 


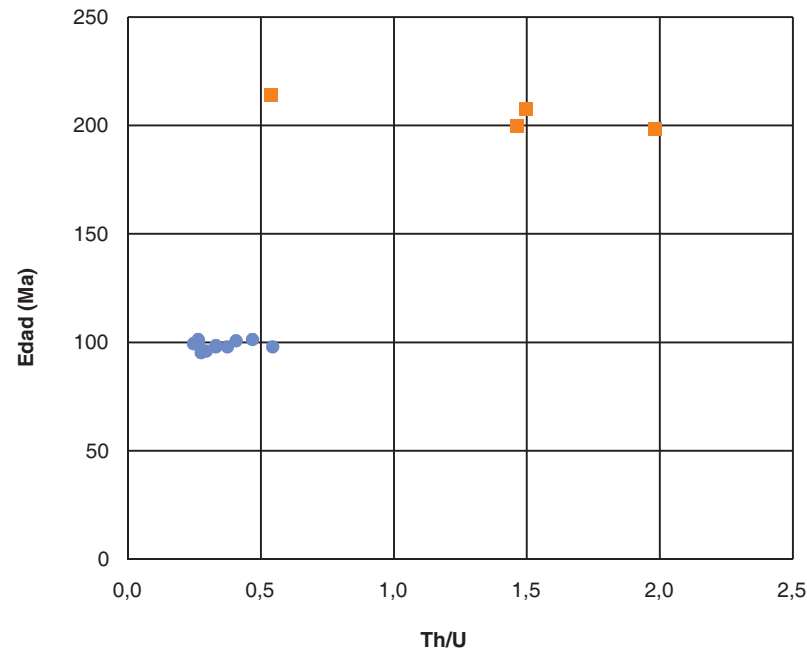

Figura 82. Diagrama de relación Th/U vs. edad en circones de la muestra GZ-6829B. Cuadros naranja: circones heredados; círculos rellenos azules: datos cretácicos

\subsection{Interpretación de las variaciones de edades triásico-jurásicas}

Al observar los resultados de las edades promedio de las diferentes muestras (se resumen en la tabla 12) y las dos figuras siguientes ( 83 y 84 ) se aprecia que la mayor parte de las muestras exhibe una distribución amplia en el tiempo, principalmente entre 205 y 190 Ma. Los valores de MSWD de casi todas las edades obtenidas son altos, lo que indica dispersión alta y que las edades no son precisas. Esta dispersión se debe probablemente al registro de varios procesos geológicos. Sin embargo, no es posible profundizar en la interpretación, debido a que de algunas muestras no se dispone de buenas imágenes de CL y a que no se conocen los lugares exactos donde se realizaron las ablaciones.
Miller, Matzel, Miller, Burgess y Miller (2007) plantean que si las edades se extienden a lo largo de la concordia, pero con algunas superposiciones de las elipses individuales de errores, se obtiene una dispersión alta que se puede deber a varios factores: 1 ) pérdida de plomo; 2) análisis de circón magmático junto con un componente menor de circón heredado del fundido; 3) la incorporación de xenocristales, o 4) el reciclaje de antecristales solidificados en etapas iniciales o parcialmente solidificados en el sistema magmático. La dispersión alta está expresada por valores de MSWD > 1, normalmente mayores de 2, lo que indica, siempre y cuando la pérdida de plomo sea insignificante, que los circones no pudieron haber cristalizado todos al mismo tiempo, a pesar de su semejanza en edad. En estos casos no es fácil asignar una edad única como edad de cristalización de la roca. 

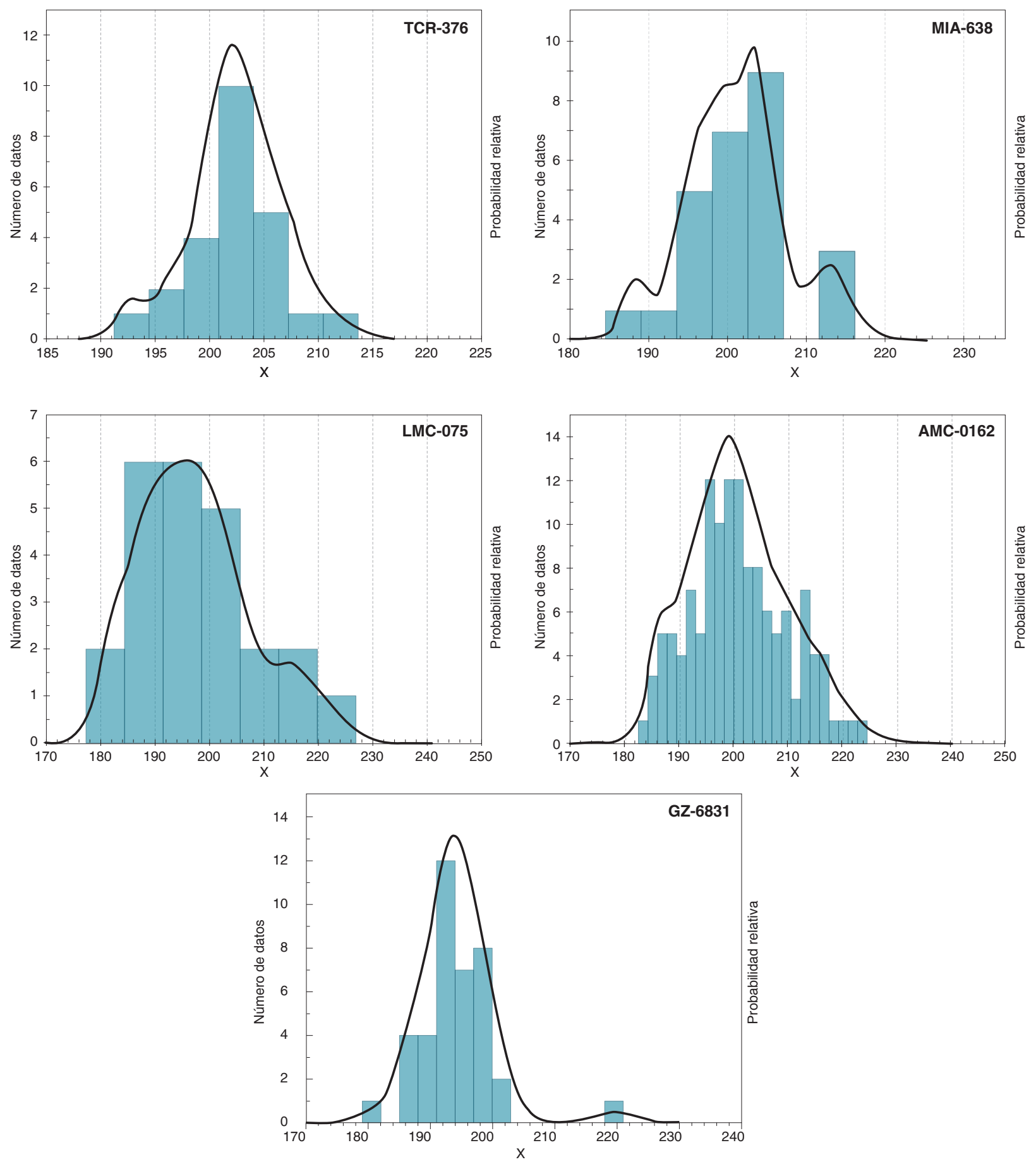

Figura 83. Diagramas de densidad de probabilidad para las edades triásico-jurásicas de las rocas del cuerpo principal del Batolito de Mogotes 

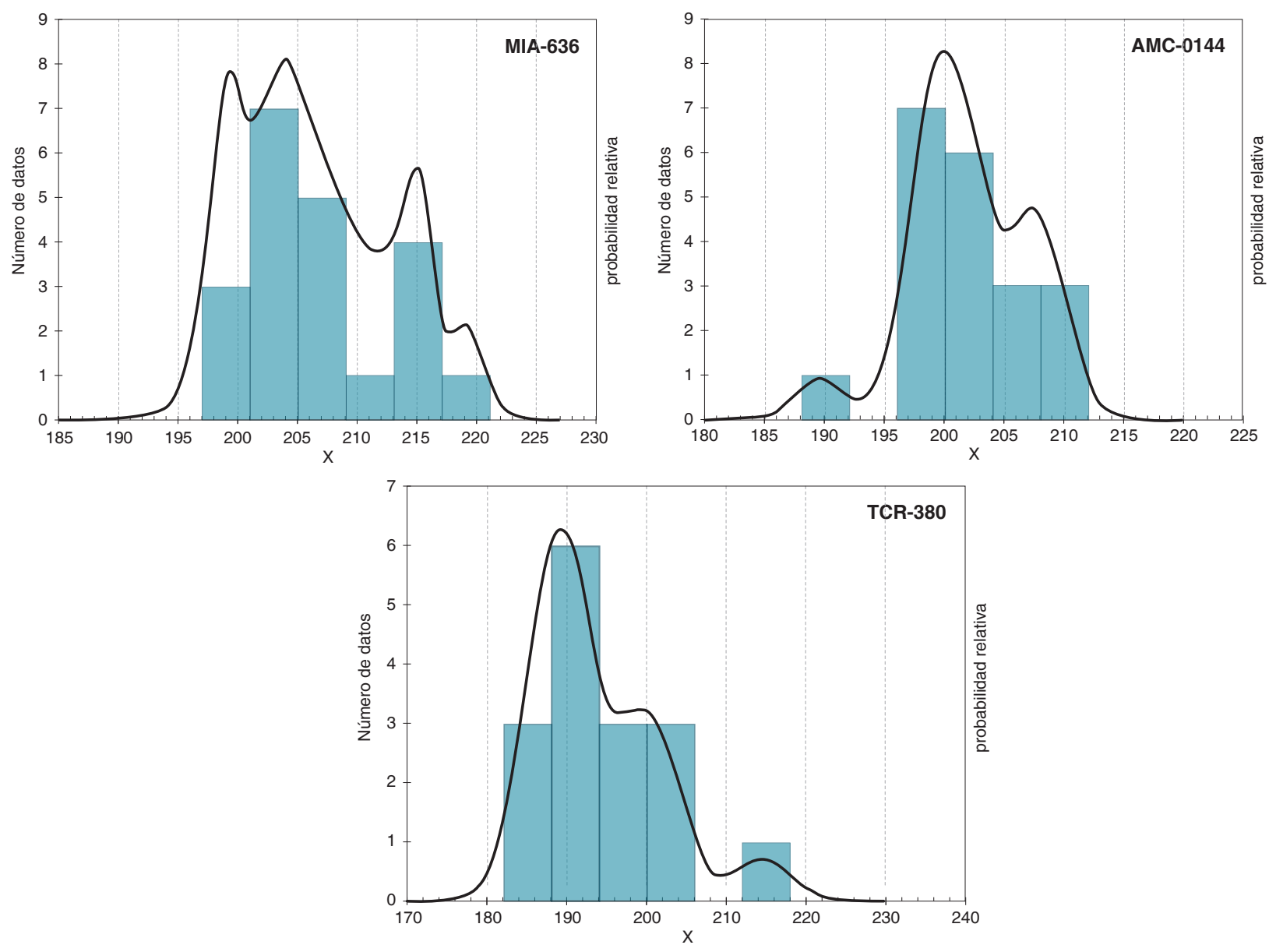

Figura 84. Diagramas de densidad de probabilidad para las edades triásico-jurásicas de rocas de cuerpos menores (MIA-636 y AMC-0144) y dique (TCR-380) en el Batolito de Mogotes

De acuerdo con los datos de todas las muestras, el proceso de cristalización del Batolito de Mogotes empezó aproximadamente entre los 220 y $215 \mathrm{Ma}$ (antecristales), y fue un proceso prolongado de cristalización, con un posible evento principal ocurrido alrededor de los 205-200 Ma. Los datos de dos muestras (GZ-6831 y AMC-0162) de baja dispersión sugieren que la cristalización final de las rocas del Batolito de Mogotes ocurrió hacia los $190 \mathrm{Ma}$ o al menos el de estas rocas. La edad de un dique máfico (TCR-380) se dató en aproximadamente $190 \mathrm{Ma}$, si bien también tiene registro de edades cercanas a los $200 \mathrm{Ma}$.

Otra alternativa para explicar los circones más jóvenes de la muestra AMC-0162 es que el evento de cristalización fue el de aproximadamente $200 \mathrm{Ma}$, mientras que las edades más jóvenes pueden haber resultado de pérdida de $\mathrm{Pb}$ por metamictización de los bordes de los circones.

\section{Correlación}

El Batolito de Mogotes fue correlacionado con la cuarzomonzonita de Santa Bárbara por Ward et al. (1973) y con el Granito de Pescadero por Goldsmith et al. (1971) y Ward et al. (1973).

El Batolito de Mogotes es correlacionable en composición litológica, química, edad y posición tectónica con otros plutones de edades triásico-jurásicas que afloran en el Macizo de Santander, presentados en esta publicación, entre los que se encuentra el Monzogranito de Santa Bárbara - antes Cuarzomonzonita de Santa Bárbara- (Ward et al., 1973; Rodríguez et al., 2018), el granito de Pescadero (Ward et al., 1973; Zapata et al., 2016), el Monzogranito de Rionegro - antes Batolito de Rionegro- (Ward et al., 1973; Arango et al., 2016). Difiere parcialmente del Monzogranito de La Corcova - antes Cuarzomonzonita de La Corcova - (Ward et al., 1973; Rodríguez et al., 2016), este último compuesto 
por rocas con características de granito tipo-S, como son la presencia de feldespato potásico de color blanco, moscovita y biotita, escasa hornblenda y presencia de ilmenita y el hecho de ser peraluminosos, rasgos comunes en plutones altamente diferenciados, según Chappell y White (2001).

Al comparar las edades de los pulsos encontrados en el Batolito de Mogotes y las edades en diques y cuerpos menores asociados, algunos de estos pulsos resultan comunes a otros plutones del Macizo de Santander, lo que sugiere que se trata de un magmatismo multipulsos que formó a cada plutón.

De acuerdo con la información geocronológica $\mathrm{U}-\mathrm{Pb}$ de Van der Lelij (2013) y todas las edades presentadas en este trabajo, los plutones triásico-jurásicos del Macizo de Santander son más antiguos que los del valle superior del Magdalena, que presentan edades entre 182 y 169 Ma (Rodríguez et al., 2018 ); por lo tanto, los plutones de ambos lugares no son correlacionables.

\section{Génesis}

Los monzogranitos presentan una mineralogía característica de granitoides tipo I, como son la presencia de feldespato potásico rosado, biotita parda, escasa hornblenda y presencia de magnetita, común en plutones altamente diferenciados, según Chappell y White (2001). Asimismo, desde el punto de vista geoquímico, grafican en el campo de los granitos tipo I (figura 38).

Otro criterio que indica que los granitos son de tipo I es el de la relación $\mathrm{Pb}$ vs. Th, donde gran parte de los circones grafican en el campo de los granitos tipo I (figuras 47, 50B, 67B y 71B). Por otro lado, la química mineral obtenida en un cristal de biotita, relacionada a un monzogranito de la facies principal del batolito, se asocia a rocas de series calcoalcalinas orogénicas (figura 30).

En el diagrama $\mathrm{SiO}_{2}$ vs. $\mathrm{Rb} / \mathrm{Zr}$ (figura 85), las muestras se ubican en el campo de los granitos de arco volcánico y granitos tardíos o poscolisionales.

Tanto los patrones de REE como las variaciones en las edades sugieren que el batolito fue resultado de varios pulsos magmáticos, posiblemente en un ambiente de arco magmático de margen continental.

Con relación a la génesis de los cuerpos menores y diques, las rocas de ambos tipos grafican en el campo de las rocas volcánicas de arco (figura 86A). En el diagrama

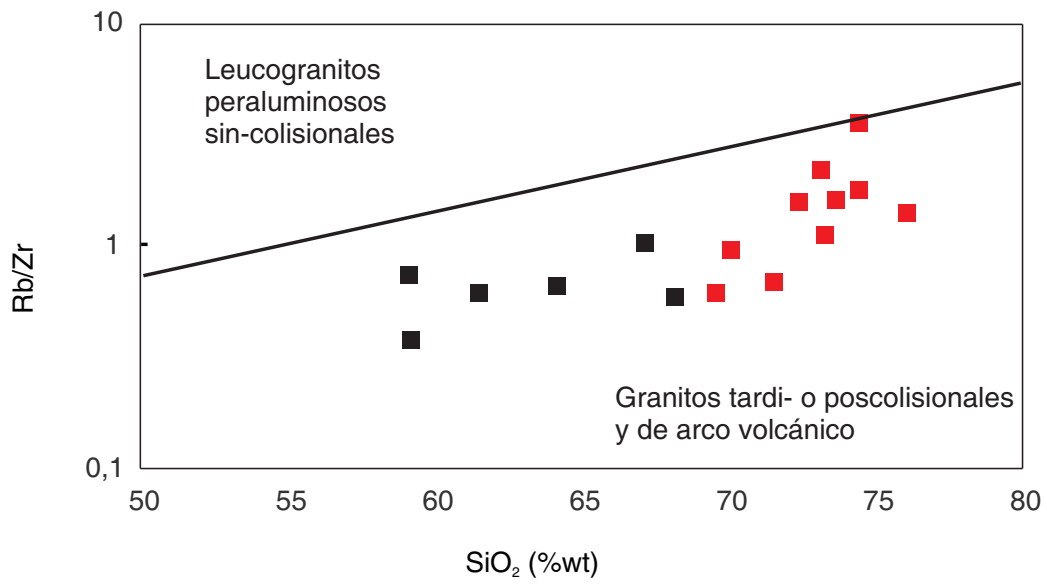

Figura 85. Diagrama de $\mathrm{SiO}_{2}$ vs. $\mathrm{Rb} / \mathrm{Zr}$ de Harris et al. (1986). Símbolos: cuadrados rojos: monzogranitos, sienogranitos y cuarzomonzonitas; en cuadrados negros, granodioritas, cuarzomonzodioritas, cuarzodioritas y tonalita 
de Harris et al. (1986) pertenecen al campo de granitos de arco volcánico tardi o posorogénico (figura 86B).

Los diques cretácicos tienen características químicas diferentes de las que predominan en las rocas jurásicas. La muestra IGM900868, de composición diorítica o to-

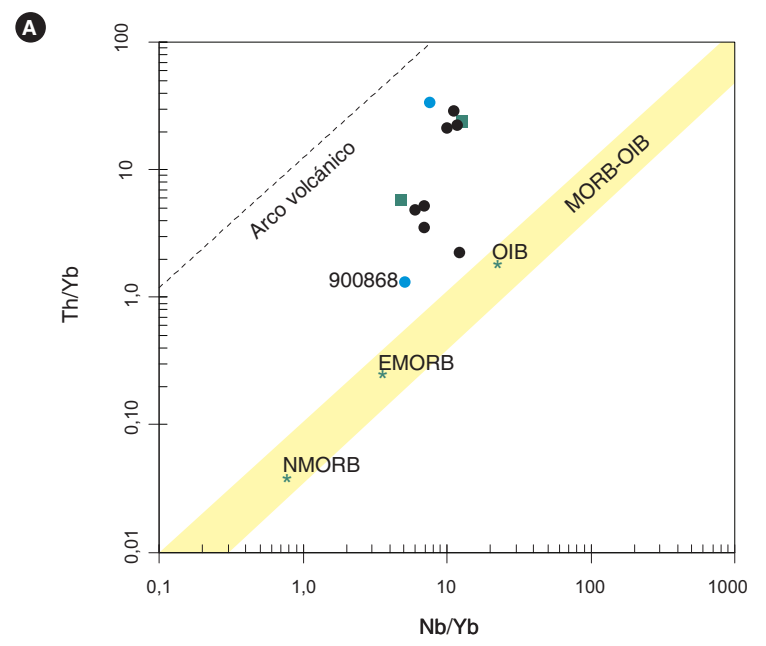

nalítica, arrojó una edad de $108 \mathrm{Ma}$ y en todos los diagramas grafica en campos diferentes de aquellos en que grafican las otras. Por otro lado, la muestra IGM900901, que es un sienogranito, reportó una edad de ca. 99 Ma, y también grafica separada de las otras muestras.
B

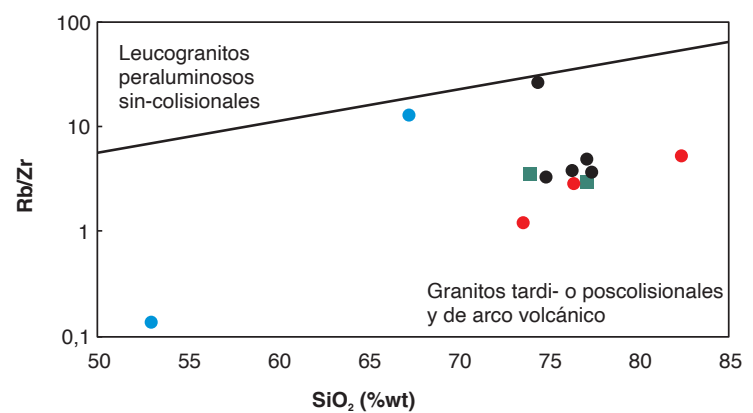

Figura 86. Diagramas de discriminación de ambiente tectónico correspondientes a rocas de cuerpos menores y diques del Batolito de Mogotes. A) Diagrama de Pearce (2008), correspondiente a rocas de arco y rocas de corteza oceánica. B) Diagrama de SiO2 vs. Rb/Zr de Harris et al. (1986). Símbolos: cuadrados verdes: cuerpos menores; círculos negros: diques jurásicos plutónicos; círculos rojos: diques jurásicos subvolcánicos; círculos azules: diques cretácicos

\section{Recursos minerales}

Los recursos minerales potenciales identificados en el Batolito de Mogotes corresponden a materiales de construcción, específicamente piedras ornamentales (Ingeominas, 2001).

Las alteraciones hidrotermales de sericitización, argilización y cloritización sugieren potencial de mineralizaciones metálicas, pero a la fecha no se han identificado anomalías químicas que indiquen la presencia de estas mineralizaciones.

\section{Conclusiones}

El Batolito de Mogotes está compuesto principalmente de monzogranitos y, en menor proporción, de granodioritas. También contiene cuerpos menores de composición semejante a la masa principal y es atravesado por diques principalmente félsicos y, en menor cantidad, intermedios a máficos.
Los monzogranitos consisten de feldespato potásico, cuarzo, plagioclasa oligoclasa hasta andesina, biotita y magnetita, y pueden también contener ilmenita. Las granodioritas tienen, además, anfíbol. La composición del feldespato potásico, determinada ópticamente y por química mineral, es de ortosa y ortosa pertítica, y la composición de las plagioclasas, según el método de Michel-Lévy, varía entre oligoclasa $\mathrm{An}_{28}$ y andesina $\mathrm{An}_{38}$, mientras que la química mineral mostró un rango más amplio en la composición, desde albita $\mathrm{An}_{9}$ a andesina $\mathrm{An}_{31}$.

Los diques félsicos son monzogranitos y sienogranitos, y los intermedios a máficos son granodiorita, tonalita y andesita.

La mayor parte de las muestras exhiben meteorización y/o alteración hidrotermal moderada a alta, en la que la plagioclasa se ha alterado a sericita, el feldespato potásico a arcillas, y la biotita a clorita. En algunas 
muestras se observa crecimiento mirmequítico posterior a la textura alotriomórfica inequigranular, que probablemente es el resultado de un metasomatismo potásico.

La composición química de roca total de las rocas no alteradas, o con leve alteración, indica que el Batolito de Mogotes es un plutón subalcalino de la serie calco-alcalina alta en $\mathrm{K}$, levemente peraluminoso, generado en un ambiente relacionado con subducción, probablemente en un arco volcánico continental. Los cuerpos menores y los diques muestran características químicas semejantes a las de las rocas del cuerpo principal, excepto el dique de microtonalita (IGM90868), que es de la serie calcoalcalina.

Tanto la litogeoquímica como el contenido de elementos traza de los circones indican que las rocas son granitos tipo I.

En un monzogranito del cuerpo principal del Batolito de Mogotes se hallaron abundantes herencias del Paleozoico, que van desde el Ordovícico Superior hasta el Carbonífero Temprano (Mississipiano) y del Pérmico, y en menor cantidad del Meso-Neoproterozoico y del Triásico. El resto de muestras del cuerpo principal, los cuerpos menores y los diques jurásicos mostraron escasas herencias del Meso-Neoproterozoico y del Paleozoico y Triásico. El dique cretácico de microtonalita (108 Ma) mostró dos valores heredados del Mesoproterozoico y dos del Triásico, mientras que el dique cretácico de sienogranito (99 Ma) mostró tres edades heredadas del Triásico Tardío.

Las edades ígneas de las rocas del cuerpo principal se ubican principalmente entre los 205 y los $190 \mathrm{Ma}$. La mayor parte de las edades muestran alta dispersión, y solo dos muestras (GZ-6831 y AMC-0162) evidencian dispersión relativamente baja, que apunta a una cristalización final del batolito hacia los $190 \mathrm{Ma}$, así que las edades más antiguas, que llegan hasta los $220 \mathrm{Ma}$, podrían considerarse antecristales formados en una etapa más temprana del magmatismo.

Los cuerpos menores tienen edades U-Pb en circón principalmente entre 205 y 202 Ma, y también muestran edades más antiguas, próximas a los 210 Ma. Hay diques jurásicos cuyas edades de cristalización oscilan alrededor de los $190 \mathrm{Ma}$ y otros cretácicos con edades de aproximadamente 108 y 99 Ma. Estos últimos diques indican una actividad magmática cretácica en el Macizo de Santander que es poco conocida.
Las variaciones composicionales y los rangos de edades obtenidas por el método U-Pb en circón sugieren que el Batolito de Mogotes es un plutón compuesto y que se generó a partir de diferentes pulsos magmáticos. Las abundantes herencias del Paleozoico, y en menor proporción del Meso-Neoproterozoico, en las rocas monzograníticas, sugieren un aporte importante de corteza continental en el magma que dio origen al Batolito de Mogotes.

El Batolito de Mogotes es correlacionable con el Monzogranito de Rionegro, el Monzogranito Santa Bárbara y el Granito de Pescadero, y parcialmente correlacionable con el Monzogranito de La Corcova, situado en el Macizo de Santander; en cambio, no es correlacionable con los plutones del Valle Superior del Magdalena, por ser más antiguo que aquellos.

\section{Referencias}

Abdel-Rahman, A. F. M. (1994). Nature of biotites from alkaline, calc-alkaline, and peraluminous magmas. Journal of Petrology, 35 (2), 525-541. https://doi. org/10.1093/petrology/35.2.525.

Arango, M. I., Rodríguez, G., Zapata, G. y Correa M., A. M. (2016). Catálogo de unidades litoestratigráficas de Colombia. Monzogranito de Rionegro, cordillera Oriental, departamento Santander. Medellín: Servicio Geológico Colombiano.

Cardona, A. (2003). Correlações entre fragmentos do embasamento Pre-Mesozoico da terminação setentrional dos Andes colombianos, com base em dados isotópicos e geocronológicos (tesis de maestría), Universidade de São Paulo.

Castro Dorado, A. (2015). Petrografía de rocas ígneas y metamórficas. Madrid: Ediciones Paraninfo.

Cediel, F. (1969). Geología del Macizo de Floresta. En Primer Congreso Colombiano de Geología. Memoria. Bogotá.

Chappell, B. W. y White, A. J. (2001). Two contrasting granite types: 25 years later. Australian Journal of Earth Sciences, 48 (4), 489-499. https://doi.org/10.1046/j.1440-0952.2001.00882.x.

Chappell, B. W.y White, A. J. R. (1974). Two contrasting granite types. Pacific Geology, 8 (2), 173-1 74.

Clavijo, J. (1994). Mapa geológico generalizado de Norte de Santander. Escala 1:250.000. Mapa interno. Bucaramanga: Ingeominas. 
Cordani, U. G., Cardona, A., Jiménez, D. M., Liu, D. y Nutran, A. P. (2005). Geochronology of Proterozoic basement inliers from the Colombian Andes: Tectonic history of remnants from a fragmented Grenville belt. Londres: Geological Society. https://doi. org/10.1144/GSL.SP.2005.246.01.13.

Droop, G. T. R. (1987). A general equation for estimating $\mathrm{Fe} 3+$ concentrations in ferromagnesian silicates and oxides from microprobe analyses, using stoichiometric criteria. Mineralogical Magazine, 51 (361), 431-435. https://doi.org/10.1180/minmag.1987.051.361.10.

Etayo Serna, F., Barrero, D., Lozano, H., Espinosa, A., González, H., Orrego, A., Ballesteros, I., Forero, H., Ramírez, C., Zambrano Ortiz, F., Duque Caro, H., Vargas, R., Núñez, A., Álvarez, J., Ropaín, C., Cardozo, E., Galvis, N., Sarmiento, L., Alberts, J. P., Case, J. E., Singer, D. A., Bowen, R. W., Berger, B. R., Cox, D. P. y Hodges, C. A. (1 985). Mapa de terrenos geológicos de Colombia. Publicaciones Geológicas Especiales del Ingeominas 14, Bogotá: Ingeominas.

García, C. y Ríos, C. (1 999). Metamorfismo y metalogenia asociada del Macizo de Santander, cordillera Oriental, Colombia. Informe final del Proyecto de Investigación 1102-05-083-95. Bucaramanga: Colciencias-Universidad Industrial de Santander.

Goldsmith, R., Marvin, R. F. y Mehnert, H. H. (1971). Radiometric ages in the Santander Massif, Eastern Cordillera, Colombian Andes. U. S. Geological Survey Professional Paper 750-D, D44-D49.

Harris, N. B. W., Pearce, J. A. y Tindle, A. G. (1 986). Geochemical characteristics of collision zone magmatism. En M. P. Coward y A. C. Ries (eds.), Collision tectonics (pp. 67-81). Special publication 19. London: Geological Society of London. http://dx.doi. org/10.10.1144/GSL.SP.1986.019.01.04.

Hastie, A. R., Kerr, A. C., Pearce, J. A. y Mitchell, S. F. (2007). Classification of altered volcanic island arc rocks using immobile trace elements: development of the Th-Co discrimination diagram. Journal of Petrology, 48 (12), 2341-2357. https:/doi. org/10.1093/petrology/egm062.

Hughes, C. J. (1972). Spilites, keratophyres and the igneous spectrum. Geological Magazine, 109 (6), 513527. https://doi.org/1 0.1 01 7/S0016756800042795.
Ingeominas. (2001). Mapa de recursos minerales de Colombia. Materiales de construcción. Plancha 5-06. Escala 1:500.000. Bogotá: Ingeominas.

International Subcommision on Stratigraphic Classification. (1987). Stratigraphic classification and nomenclature of igneous and metamorphic rock bodies. Geological Society America Bulletin 99 (3), 440-442. https://doi.org/10.1130/0016-7606(1987)99<440:SCANOI $>2.0 . \mathrm{CO} ; 2$.

International Subcommision on Stratigraphic Classification. (1994). International stratigraphic guide: A guide to stratigraphic classification, terminology and procedure (2. a ed.). Amos Salvador (ed.). Boulder: The International Union of Geological Sciences y Geological Society of America.

Janoušek, V., Farrow, C. M. y Erban, V. (2006). Interpretation of whole-rock geochemical data in igneous geochemistry: Introducing geochemical data toolkit (GCDkit). Journal of Petrology, 47 (6), 1255-1259. https://doi.org/1 0.1 093/petrology/egl013.

Large, R. R., Gemmel, J. B., Paulick, H. y Huston, D. L. (2001). The alteration box plot: A simple approach to understanding the relationship between alteration mineralogy and lithogeochemistry associated with volcanic-hosted massive sulfide deposits. Economic Geology, 96 (5), 957-971. https://doi.org/10.2113/ gsecongeo.96.5.957.

Leal-Mejía, H. (2011). Phanerozoic gold metallogeny in the Colombian Andes: A tectono-magmatic approach (tesis de doctorado). Universitat de Barcelona, España.

Ludwig, K. R. (2012). User's manual for Isoplot 3.7 5-4.15. A geochronological toolkit Microsoft Excel. Special publication n. ${ }^{\circ}$. Berkeley Geochronology Center.

Mantilla Figueroa, L. C., Bissig, T., Cottle, J. M. y Hart, C. J. (2012). Remains of early Ordovician mantle-derived magmatism in the Santander Massif (Colombian Eastern Cordillera). Journal of South American Earth Sciences, 38, 1-12. https://doi.org/10.1016/j. jsames.2012.03.001.

Mantilla Figueroa, L. C., Bissig, T., Valencia. V. y Hart, C. (2013). The magmatic history of the Vetas-California mining district, Santander Massif Eastern Cordillera, Colombia. Journal of South American Earth Sciences, 45, 235-249. https://doi.org/10.1016/j.jsames.2013.03.006.

Mantilla-Figueroa, L. C., García-Ramírez, C. A. y Valencia, V. A. (2016). Propuesta de escisión de la deno- 
minada 'Formación Silgará' (Macizo de Santander, Colombia), a partir de edades U-Pb en circones detríticos. Boletín de Geología, 38 (1), 33-50. https:// doi.org/1 0.1 8273/revbol.v38n1-2016002.

McDonough, W. F. y Sun, S. S. (1995). The composition of the Earth. Chemical Geology, 120 (3), 223-253. https://doi.org/1 0.1016/0009-2541(94)001 40-4.

Middlemost, E. A. K. (1985). Magmas and magmatic roc$k s$. London: Longman.

Middlemost, E. A. K. (1994). Naming materials in the magma/igneous rock system. Earth-Science Reviews, 37 (3-4), 215-224. https://doi.org/1 0.1016/001 28252(94)90029-9.

Miller, J. S., Matzel, J. E., Miller, C. F., Burgess, S. D. y Miller, R. B. (2007). Zircon growth and recycling during the assembly of large, composite arc plutons. Journal of Volcanology and Geothermal Research, 167 (1-4), 282-299. https://doi.org/10.1016/j.jvolgeores.2007.04.019.

Nakamura, N. (1974). Determination of REE, Ba, Fe, Mg, $\mathrm{Na}$ and $\mathrm{K}$ in carbonaceous and ordinary chondrites. Geochimical et Cosmochimical Acta, 38 (5), 757-775. https://doi.org/1 0.1 016/001 6-7037(74)90149-5.

Pearce, J. A. (2008). Geochemical fingerprinting of oceanic basalts with applications to ophiolite classification and the search for Archean oceanic crust. Lithos, 100 (1-4), 14-48. https://doi.org/10.1016/j. lithos.2007.06.016.

Peccerillo, A. y Taylor, S. R. (1976). Geochemistry of Eocene calc-alkaline volcanic rocks from the Kastamonu area, Northern Turkey. Contributions to Mineralogy and Petrology, 58 (1), 63-81. https://doi. org/10.1007/BF00384745.

Restrepo, J.J y Toussaint, J. F. (1989). Terrenos alóctonos en los Andes colombianos: explicación de algunas paradojas. V Congreso Colombiano de Geología. Bucaramanga.

Restrepo, J. J., Ordóñez Carmona, O., Armstrong, R. y Pimentel, M. (2011). Triassic metamorphism in the northern part of the Tahamí Terrane of the Central Cordillera of Colombia. Journal of South American Earth Sciences, 32 (4), 497-507. https://doi. org/10.1016/j.jsames.2011.04.009.

Restrepo, P. A. (1995). Late Precambrian to early Mesozoic tectonic evolution of the Colombian Andes, based on new geochronological, geochemical and isotopic data (tesis de Ph. D.). The University of Arizona.

Restrepo-Pace, P., Ruiz, J., Gehrels, G. y Cosca, M. (1997). Geochronology and Nd isotopic data of the Grenville-age rocks in the Colombian Andes: New constraints for Late Proterozoic-Early Paleozoic paleocontinental reconstructions of the Americas. Earth and Planetary Science Letters, 150 (3-4), 427-441. https://doi.org/1 0.1016/S001 2-821X(97)00091-5.

Rieder, M., Cavazzini, G., D’Yakonov, Y., Frank Kamenetskii, V., Gottardi, G., Guggenheim, S., Koval, P. W., Müller, G., Neiva, A. M. R., Radoslovich, E. W., Robert, J.-L., Sassi, F. P., Takeda, H., Weiss, Z. y Wones, D. R. (1998). Nomenclature of the micas. Clays and Clay Minerals, 46 (5), 586-595. https://doi. org/1 0.1346/CCMN.1998.0460513.

Rodríguez, G., Arango, M. I., Zapata, G. y Bermúdez, J. G. (2018). Petrotectonic characteristics, geochemistry, and U-Pb geochronology of Jurassic plutons in the Upper Magdalena Valley-Colombia: Implications on the evolution of magmatic arcs in the NW Andes. Journal of South American Earth Sciences, 81, 10-30. https://doi.org/10.1016/j.jsames.2017.10.012.

Rodríguez, G., Correa M., A. M., Zapata, G. y Arango, M. I. (2016). Catálogo de unidades litoestratigráficas de Colombia. Monzogranito de La Corcova. Medellín: Servicio Geológico Colombiano.

Rodríguez, G., Zapata, G., Arango, M. I. y Correa M., A. M. (201 8). Catálogo de unidades litoestratigráficas de Colombia. Monzogranito de Santa Bárbara. Medellín: Servicio Geológico Colombiano.

Royero, J. M. y Clavijo, J. (2001). Mapa geológico generalizado del departamento de Santander. Escala 1:300.000. Memoria explicativa. Bogotá: Ingeominas.

Rubatto, D. (2002). Zircon trace element geochemistry: Partitioning with garnet and the link between U-Pb ages and metamorphism. Chemical Geology, 184 (1-2), 123-138. https://doi.org/10.1016/S00092541(01)00355-2.

Shand, S. J. (1943). Eruptive rocks: Their genesis, composition, classification, and their relation to ore-deposits with a chapter on meteorite. New York: John Wiley \& Sons.

Smith, J. V. y Brown, W. L. (1988). Feldspar minerals. I. Crystal structures, physical, chemical and microtextural properties (2. ${ }^{\mathrm{a}}$ ed.). Berlin: Springer-Verlag. 
Streckeisen, A. (1978). Classification and nomenclature of volcanic rocks, lamprophyres, carbonatites and melilitic rocks; recommendation and suggestions. Neues Jahrbuch für Mineralogie, 134, 1-14.

Streckeisen, A. L. (1974). Classification and nomenclature of plutonic rocks recommendations of the IUGS Subcommission on the Systematics of Igneous Rocks. Geologische Rundschau, 63 (2), 773-785. https:// doi.org/10.1007/BF01820841.

Sun, S. S. y Mcdonough, W. S. (1989). Chemical and isotopic systematics of oceanic basalts: Implications for mantle composition and processes. Special Publications 42. London: Geological Society.

Travis, R. B. (1955). Classification of rocks, vol. 50. Golden: Colorado School of Mines.

Urueña Suárez, C. L. (2014). Metamorfismo, exhumación y termocronología del Neis de Bucaramanga (Macizo de Santander, Colombia) (tesis de maestría). Universidad Nacional de Colombia.

Van der Lelij, R. (2013). Reconstructing North-Western Gondwana with implications for the evolution of the Iapetus and Rheic Oceans: A geochronological, thermochronological and geochemical study (tesis de doctorado). Université de Genève.

Vargas, R., Arias, A., Jaramillo, L. y Téllez, N. (1976a). Geología del cuadrángulo I-13, Málaga. Bogotá: Ingeominas.

Vargas, R., Arias, A., Jaramillo, L. y Téllez, N. (1976b). Mapa geológico del cuadrángulo I-13, Soatá. Escala 1:100.000. Bogotá: Ingeominas.

Vargas, R., Arias, A., Jaramillo, L. y Téllez, N. (1976c). Plancha 136 Málaga, escala 1:100.000. Bogotá: Ingeominas.
Vargas, R., Arias, A., Jaramillo, L. y Téllez, N. (1981). Geología del cuadrángulo I-13, Málaga. Boletin Geológico, 24 (3), $1-76$.

Vargas, R., Arias, A., Jaramillo, L. y Téllez, N. (1984). Geología de la Plancha 136 Málaga. Mapa, escala: 1:100.000. Versión digital 2009. Bogotá: Ingeominas.

Vargas, R., Arias, A., Jaramillo, L. y Téllez, N. (1987). Geología de la Plancha 152 Soatá. Mapa, escala: 1:100.000. Versión digital 2009. Bogotá: Ingeominas.

Wang, Q., Zhu, D. C., Zhao, Z. D., Guan, Q., Zhang, X. Q., Sui, Q. L., Chu Hu, Z. y Mo, X. X. (2012). Magmatic zircons from I-, S- and A-type granitoids in Tibet: Trace element characteristics and their application to detrital zircon provenance study. Journal of Asian Earth Sciences, 53, 59-66. https://doi.org/10.1016/j. jseaes.2011.07.027.

Ward, D. E., Goldsmith, R., Cruz, J., Téllez, N. y Jaramillo, L. (1977). Mapa geológico de San Gil y Málaga (parte de los cuadrángulos I-12 y I-13), Colombia. Escala: 1:100.000. Bogotá: Ingeominas.

Ward, D., Goldsmith, R., Cruz, J. y Restrepo, A. (1973). Geología de los cuadrángulos H-1 2 Bucaramanga y H-13 Pamplona, departamento de Santander. Boletín Geológico, 21 (1-3), 1-132.

Whitney, D. L. y Evans, B. W. (2010). Abbreviations for names of rock-forming minerals. American Mineralogist, 95 (1), 185-187. https://doi.org/10.2138/ am.2010.3371.

Zapata, G., Correa M, A. M., Rodríguez, G. y Arango, M. I. (2016). Catálogo de unidades litoestratigráficas de Colombia. Granito de Pescadero. Medellín: Servicio Geológico Colombiano. 


\section{ANEXOS}

\section{Anexo 1. Resultados de geocronología U-Pb en circón de muestras del Batolito de Mogotes}

Anexo 1.1. Resultados isotópicos U-Pb en circón de la muestra TCR-376

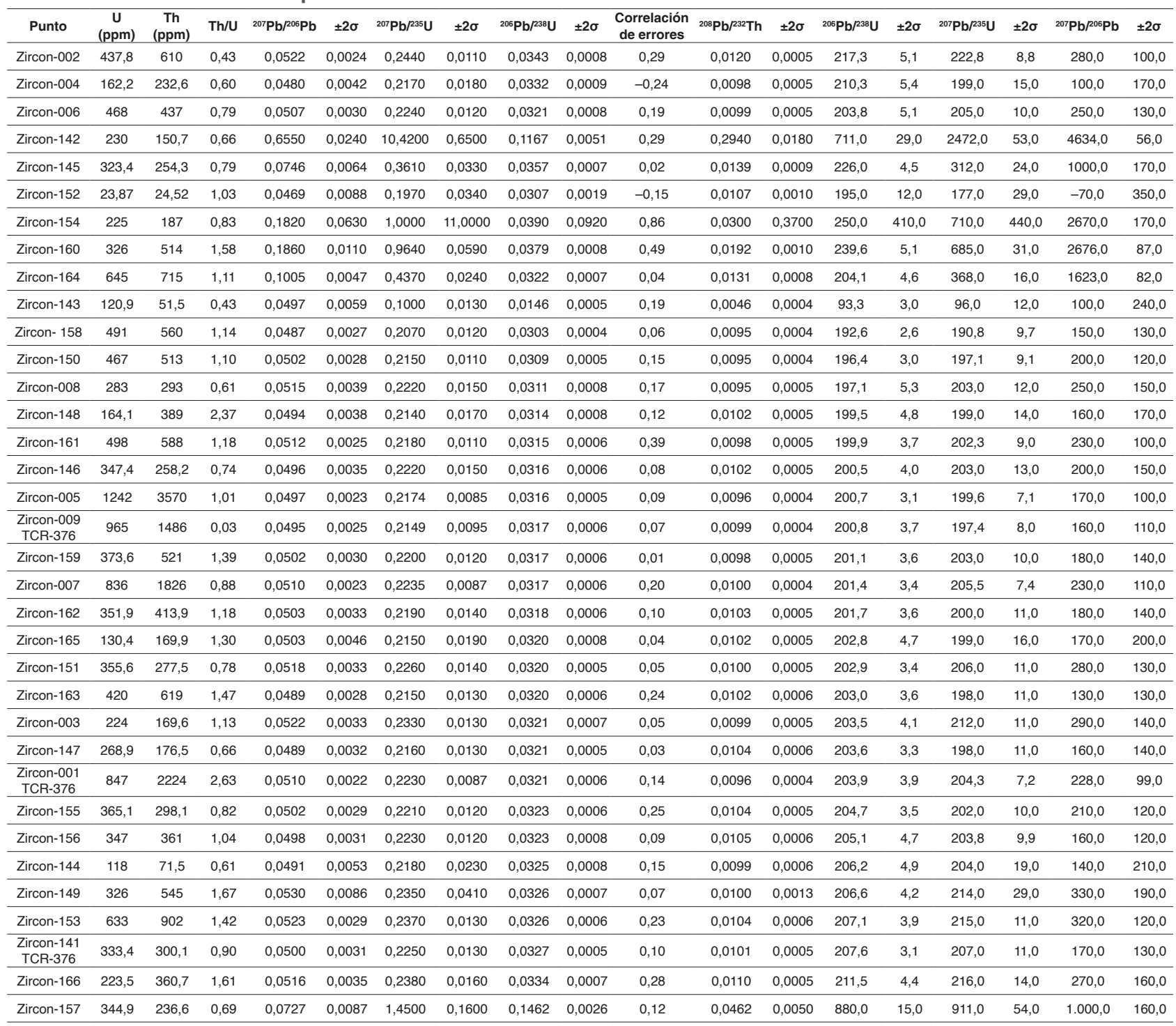


Anexo 1.2. Resultados isotópicos U-Pb en circón de la muestra MIA-638

\begin{tabular}{|c|c|c|c|c|c|c|c|c|c|c|c|c|c|c|c|c|c|c|}
\hline Punto & $\begin{array}{c}U \\
\text { (ppm) }\end{array}$ & $\begin{array}{c}\text { Th } \\
\text { (ppm) }\end{array}$ & $\mathrm{I}$ & $b^{2 / 206} \mathrm{~Pb}$ & $\pm 2 \sigma$ & $\mathrm{Pb} /{ }^{235} \mathrm{U}$ & $\pm 2 \sigma$ & $\mathrm{Pb} /{ }^{238} \mathrm{U}$ & $\pm 2 \sigma$ & $\begin{array}{c}\text { Correlación } \\
\text { de errores }\end{array}$ & 20 & $\pm 2 \sigma$ & $\mathrm{Pb} /{ }^{238} \mathrm{U}$ & $\pm 2 \sigma$ & ${ }^{7} \mathrm{~Pb} /{ }^{235} \mathrm{U}$ & $\pm 2 \sigma$ & ${ }^{06} \mathrm{~Pb}$ & $\pm 2 \sigma$ \\
\hline rcon-087 & 12 & 488 & 3 & 0571 & 0064 & 246 & 0,035 & 0312 & 0,0011 & 0,35373 & 0,01019 & 0,00067 & 198 & 6,6 & 223 & 26 & 460 & 170 \\
\hline rcon-92 & 195 & 33,6 & 0,2 & 0733 & 0033 & 695 & 0,068 & 0,169 & 0,0028 & 0,02316 & 0,0553 & 0,0031 & 1.006 & 15 & 1005 & 25 & .012 & 89 \\
\hline ircon-10 & 607 & 1.720 & 2,8 & 0519 & 0,0025 & 0,2119 & 0,0096 & 0,02956 & 0,00051 & 0,31085 & 0,00932 & 0,00045 & 187,8 & 3,2 & 195 & 8,4 & 280 & 110 \\
\hline ircon-075 & 340 & 600 & 0,4 & 0531 & 0,0024 & 0,2127 & 0,0098 & 0,0299 & 0,00061 & 0,294 & 0,00985 & 0,00052 & 189,9 & 3,8 & 195,6 & 8,2 & 340 & 110 \\
\hline ircon-100 & .590 & 7.300 & 4,6 & 0,0506 & 0,0022 & 0,2145 & 0,0086 & 0,0306 & 0,00053 & 0,24678 & 0,00958 & 0,00045 & 194,3 & 3,3 & 197,2 & 7,4 & 215 & 93 \\
\hline Zircon-99 & 497 & .370 & 2,8 & 0,0491 & 0,0034 & 213 & 0,013 & 0,03072 & 0,00069 & 0,080363 & 0,00945 & 0,00049 & 195, & 4,3 & 196 & 11 & 180 & 140 \\
\hline ircon-102 & 910 & 4.430 & 2,3 & 0514 & 0,0023 & 0,2173 & 0,0095 & 0,03076 & 0,00053 & 0,12823 & 0,01012 & 0,00052 & 195,3 & 3,3 & 199,5 & 7,9 & 250 & 100 \\
\hline ircon-078 & 550 & 3.800 & 2,5 & 0524 & 0,0024 & 0,2251 & 0,0095 & 0,03094 & 0,00048 & 0,093194 & 0,00915 & 0,00045 & 196,4 & 3 & 205,9 & 7,9 & 47 & 99 \\
\hline ircon-080 & 278 & 271 & 1,0 & 0,0515 & 0,0027 & 0,219 & 0,011 & 0,03112 & 0,0006 & 0,31837 & 0,01003 & 0,00051 & 197,6 & 3,8 & 203,5 & 9,6 & 270 & 120 \\
\hline Zircon-074 & 490 & 2.010 & 4,1 & 507 & 0032 & 0,214 & 0,013 & 0,03122 & 0,00069 & 0,31491 & 0,00988 & 0,00048 & 198, & 4,3 & 197 & 11 & 20 & 120 \\
\hline Zircon-084 & 135 & 127 & 0,9 & 0,0547 & 0,004 & 0,232 & 0,016 & 0,03127 & 0,00069 & 0,077785 & 0,01059 & 0,00057 & 198,5 & 4,3 & 211 & 13 & 320 & 160 \\
\hline 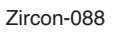 & 234 & 262 & 1,1 & 0,0556 & 37 & 234 & 014 & 0,03131 & 0,00071 & 0,28357 & 0,01031 & 0,0 & 198 & T; & 213 & 11 & 400 & 140 \\
\hline Zircon-95 & 980 & 2.930 & 1,5 & 0,0501 & 0,0021 & 0,2179 & 0,0084 & 0,03146 & 0,0005 & 0,38178 & 0,00959 & 0,00047 & 199,7 & 3,1 & 200,1 & 7 & 192 & 94 \\
\hline $\cos s+y$ & 990 & 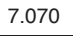 & 36 & 0,05 & 0,0021 & 0,2171 & 0 & 0 , & 1 & 9 & 4 & 6 & 199,7 & 3,2 & 199,4 & 7,2 & 197 & 4 \\
\hline rcon-93 & 266 & 596 & 2,2 & 0539 & 0,004 & 23 & 0,017 & ,0318 & 0,00071 & 0,13311 & 0,01007 & 0,00049 & 201,8 & 4,5 & 213 & 14 & 370 & 170 \\
\hline ircon-082 & 570 & 1.660 & 2,9 & 0,0528 & 0,0031 & 0,229 & 0,014 & 0,0319 & 0,001 & 8801 & 0,0101 & 13 & 202,3 & 6,4 & 209 & 11 & 310 & 130 \\
\hline Zircon-072 & 271 & 208 & 0 & ,052 & 2 & 0,227 & 13 & 85 & 7 & 383 & 02 & 0 & 20 & 4 & s & 11 & 260 & 130 \\
\hline Zircon-073 & 1.040 & 2.410 & 2,3 & 0,0525 & 0,0033 & 0,226 & 0,016 & 0,032 & 0,00082 & 0,5818 & 0,01005 & 0,0007 & 20 & 5,1 & 207 & 13 & 310 & 130 \\
\hline $\begin{array}{c}\text { Zircon-071 } \\
\text { MIA-638 }\end{array}$ & 4.030 & 1890 & 0,5 & 0503 & 0,0019 & 0,2201 & 0,0086 & 0,03204 & 0,00059 & 0,69264 & 0,01001 & 0,00049 & 203,3 & 3,7 & 201,9 & 7,1 & 204 & 33 \\
\hline Zircon-083 & 590 & 510 & 0,9 & 0,053 & 0,0029 & 0,233 & 0,013 & 0,03208 & 0,0007 & 0,021129 & 0,01018 & 0,00055 & 203,5 & 4,4 & 213 & 10 & 320 & 130 \\
\hline ron 085 & 313 & 334 & 1,1 & 0,051 & 2 & 0,226 & 4 & 2 & 7 & 0 & 19 & 0, & 2 & 4,2 & 209 & 11 & 230 & 140 \\
\hline Zircon-090 & 930 & 1.740 & 1,9 & 0,0516 & 0,0025 & 0,225 & 0,011 & 0,03215 & 0,00052 & 0,25775 & 0,01034 & 0,0005 & 20 & 3,2 & 206,8 & 8,6 & 250 & 110 \\
\hline $077>37$ & 380 & 640 & 1, & 0,0514 & 7 & 0,227 & 3 & 1 & 4 & 7 & 1 & 5 & 2 & 4 & 207 & 11 & 290 & 130 \\
\hline Zircon-94 & 492 & 670 & 1,4 & 505 & 0,0027 & 0,228 & 012 & 0,03234 & 0,00068 & 0,038382 & 0,01036 & 0,0006 & 205,2 & 4,2 & 208,6 & 9,8 & 250 & 120 \\
\hline $\begin{array}{c}\text { Zircon-103 } \\
\text { MIA-638 }\end{array}$ & 435 & 560 & 1,3 & 1508 & 0,003 & 0,228 & 0,013 & 0,03251 & 0,0007 & 0,028205 & 0,01057 & 0,00057 & 206,2 & 4,4 & 208 & 10 & 220 & 130 \\
\hline Zircon-081 & 349 & 520 & 1,5 & 515 & 0,0037 & 0,235 & 0,017 & 0334 & 0,00069 & 0,027739 & 0,01065 & 0,00076 & 211,8 & 4,3 & 214 & 14 & 240 & 150 \\
\hline 7ircon-97 & 1.500 & 208 & 0,1 & 00511 & 0,0034 & 0236 & 0,016 & 0,03349 & 0,00079 & 0,093892 & 0,01034 & 0,00069 & 212 & 4,9 & 215 & 12 & 50 & 50 \\
\hline COn-y & 551 & 634 & 1,2 & 10 & 031 & 0,239 & 0,013 & 0,0 & 08 & 0,0024094 & 0,0 & 0,0 & 21 & 5 & 21 & 11 & 220 & 130 \\
\hline Zircon-076 & 511 & 1.310 & 2,6 & 0 & $0,0 c$ & 0 & 16 & 37 & 0 & 32 & 0, & 11 & 2 & 7,1 & 48 & 13 & 80 & 110 \\
\hline coll-usi & 410 & 6 & 0,0 & 841 & 0,0033 & 4 & 0 & 4 & 0,0011 & 0,0 & 57 & 0,0038 & 3 & 0,8 & 322 & 16 & 60 & 140 \\
\hline Zircon-089 & 462 & 304 & 0,7 & 0,0643 & 0,0028 & 0,737 & 0,047 & 0,0831 & 0,0038 & 0,50541 & 0,01528 & 0,00084 & 514 & 23 & 560 & 30 & 760 & 99 \\
\hline CUn-9o & 560 & 01,0 & 0,1 & 711 & 0,0031 & 1,941 & 0,074 & 0,1835 & 0,0033 & 0,28229 & 556 & 0,0034 & 1.000 & 18 & 1.095 & 26 & $1.1<0$ & 79 \\
\hline Zircon-079 & 279 & 110 & 0,4 & 0,0996 & 0,0041 & 3,2 & 0,13 & 0,2371 & 0,0043 & 0,45209 & 0,0856 & 0,0042 & 1.371 & 23 & 1.456 & 30 & 1.627 & 77 \\
\hline
\end{tabular}


Anexo 1.3. Resultados isotópicos U-Pb en circón de la muestra LMC-075

\begin{tabular}{|c|c|c|c|c|c|c|c|c|c|c|c|c|c|c|c|c|}
\hline Punto & $\mathrm{U}(\mathrm{ppm})$ & Th (ppm) & $\mathrm{Th} / \mathrm{U}$ & $\mathrm{Pb} / 200 \mathrm{~Pb}$ & $\pm 2 \sigma$ & ${ }^{207} \mathrm{~Pb} / 235 \mathrm{U}$ & $\pm 2 \sigma$ & ${ }^{206} \mathrm{~Pb} /{ }^{238} \mathrm{U}$ & $\pm 2 \sigma$ & $\begin{array}{c}\text { Correlación } \\
\text { de errores }\end{array}$ & $\begin{array}{c}\begin{array}{c}\text { Edad }{ }^{206} \mathrm{~Pb} / 238 \mathrm{U} \\
(\mathrm{Ma})\end{array} \\
\end{array}$ & $\pm 2 \sigma$ & $\begin{array}{l}\mathrm{dad}^{207} \mathrm{~Pb} /{ }^{2355} \mathrm{U} \\
(\mathrm{Ma})\end{array}$ & $\pm 2 \sigma$ & $\begin{array}{l}\mathrm{dadad}^{207} \mathrm{~Pb} /{ }^{206 \mathrm{~Pb}} \\
(\mathrm{Ma})\end{array}$ & $=2 \sigma$ \\
\hline C-075-51 & 676,00 & 761,00 & 1,13 & 0,05470 & 0,00330 & 0,2200 & 0,0150 & 0,02872 & 0,00058 & 0,5523 & 181,41 & 6,54 & 199,00 & 12,00 & 380,00 & 110,00 \\
\hline LMC-075-26 & $1.714,00$ & $1.866,00$ & 1,09 & 0,05540 & 0,00130 & 0,2227 & 0,0056 & 0,02876 & 0,00036 & 0,3786 & 181,50 & 5,91 & 203,60 & 4,60 & 14,00 & 52,00 \\
\hline LMC-075-52 & 690,00 & 646,00 & 0,94 & 0,04850 & 0,00220 & 0,1967 & 0,0091 & 0,02878 & 0,00039 & 0,2421 & 183,19 & 6,03 & 181,60 & 7,60 & 127,00 & 85,00 \\
\hline LMC-075-44 & 228,40 & 384,00 & 1,68 & 0,05510 & 0,00400 & 0,2350 & 0,0220 & 0,02924 & 0,00056 & 0,6538 & 184,57 & 6,57 & 200,00 & 13,00 & 260,00 & 120,00 \\
\hline LMC-075-47 & 417,00 & 573,00 & 1,37 & 0,05020 & 0,00230 & 0,2079 & 0,0099 & 0,02949 & 0,00048 & 0,2871 & 187,27 & 6,41 & 192,30 & 8,30 & 204,00 & 89,00 \\
\hline LMC-075-46 & $1.430,00$ & 718,00 & 0,50 & 0,10860 & 0,00630 & 0,4780 & 0,0360 & 0,02955 & 0,00061 & 0,7802 & 174,03 & 7,06 & 388,00 & 24,00 & $1.710,00$ & 110,00 \\
\hline LMC-075-22 & 272,00 & 507,00 & 1,86 & 0,05160 & 0,00240 & 0,2095 & 0,0097 & 0,02966 & 0,00044 & 0,2407 & 188,01 & 6,29 & 192,50 & 8,20 & 242,00 & 92,00 \\
\hline LMC-075-20 & 582,00 & $1.069,00$ & 1,84 & 0,05510 & 0,00230 & 0,2290 & 0,0098 & 0,02971 & 0,00039 & 0,3869 & 187,51 & 6,18 & 208,20 & 8,00 & 412,00 & 85,00 \\
\hline LMC-075-32 & 467,00 & $1.078,00$ & 2,31 & 0,05860 & 0,00280 & 0,2330 & 0,0110 & 0,02985 & 0,00040 & 0,2549 & 187,56 & 6,26 & 211,20 & 8,60 & 480,00 & 95,00 \\
\hline LMC-075-25 & 80,30 & 113,00 & 1,41 & 0,04670 & 0,00470 & 0,1950 & 0,0200 & 0,02990 & 0,00082 & 0,0439 & 190,67 & 7,82 & 178,00 & 17,00 & 0,00 & 160,00 \\
\hline LMC-075-49 & 498,00 & 359,00 & 0,72 & 0,04690 & 0,00280 & 0,1960 & 0,0120 & 0,02991 & 0,00055 & 0,0779 & 190,69 & 6,54 & 179,70 & 9,90 & 40,00 & 110,00 \\
\hline LMC-075-5 & $2.330,00$ & $13.900,00$ & 5,97 & 0,05160 & 0,00110 & 0,2055 & 0,0060 & 0,02993 & 0,00055 & 0,6523 & 189,71 & 6,52 & 190,20 & 5,20 & 260,00 & 46,00 \\
\hline LMC-075-45 & 338,90 & 382,10 & 1,13 & 0,05130 & 0,00230 & 0,2157 & 0,0097 & 0,03010 & 0,00038 & 0,2044 & 190,85 & 6,29 & 198,20 & 8,20 & 220,00 & 86,00 \\
\hline LMC-075-21 & $1.202,00$ & $5.270,00$ & 4,38 & 0,06490 & 0,00240 & 0,2740 & 0,0110 & 0,03019 & 0,00041 & 0,4781 & 188,18 & 6,34 & 245,10 & 9,00 & 751,00 & 78,00 \\
\hline LMC-075-43 & 466,00 & 789,00 & 1,69 & 0,05130 & 0,00320 & 0,2080 & 0,0140 & 0,03030 & 0,00076 & 0,3280 & 192,10 & 7,77 & 192,00 & 11,00 & 250,00 & 120,00 \\
\hline LMC-075-18 & $2.750,00$ & $4.190,00$ & 1,52 & 0,04960 & 0,00180 & 0,2116 & 0,0090 & 0,03054 & 0,00069 & 0,4988 & 194,02 & 7,14 & 194,40 & 7,60 & 190,00 & 78,00 \\
\hline LMC-075-48 & $1.256,00$ & $1.660,00$ & 1,32 & 0,05150 & 0,00180 & 0,2221 & 0,0078 & 0,03062 & 0,00043 & 0,2466 & 194,06 & 6,41 & 203,00 & 6,50 & 256,00 & 74,00 \\
\hline LMC-075-12 & 127,10 & 258,70 & 2,04 & 0,05000 & 0,00360 & 0,2150 & 0,0160 & 0,03077 & 0,00052 & 0,1307 & 195,37 & 6,58 & 200,00 & 13,00 & 230,00 & 130,00 \\
\hline LMC-075-16 & 268,00 & 208,00 & 0,78 & 0,04950 & 0,00270 & 0,2120 & 0,0110 & 0,03093 & 0,00050 & 0,1343 & 196,50 & 6,55 & 193,20 & 9,50 & 170,00 & 100,00 \\
\hline LMC-075-10 & $1.255,00$ & $3.190,00$ & 2,54 & 0,05040 & 0,00110 & 0,2168 & 0,0046 & 0,03110 & 0,00032 & 0,3055 & 197,34 & 6,22 & 198,90 & 3,90 & 208,00 & 45,00 \\
\hline LMC-075-29 & 296,00 & 270,00 & 0,91 & 0,06200 & 0,00320 & 0,2650 & 0,0140 & 0,03132 & 0,00050 & 0,4059 & 195,87 & 6,61 & 238,00 & 12,00 & 620,00 & 110,00 \\
\hline LMC-075-42 & 259,00 & 291,00 & 1,12 & 0,04800 & 0,00230 & 0,2060 & 0,0100 & 0,03132 & 0,00048 & 0,2051 & 199,32 & 6,55 & 192,00 & 8,90 & 158,00 & 92,00 \\
\hline LMC-075-2 & 758,00 & 354,00 & 0,47 & 0,04770 & 0,00280 & 0,2030 & 0,0120 & 0,03140 & 0,00051 & 0,1024 & 199,90 & 6,55 & 187,60 & 9,90 & 110,00 & 110,00 \\
\hline LMC-075-23 & 337,00 & 616,00 & 1,83 & 0,04900 & 0,00190 & 0,2155 & 0,0085 & 0,03148 & 0,00038 & 0,1831 & 200,08 & 6,48 & 197,50 & 7,00 & 155,00 & 73,00 \\
\hline LMC-075-41 & 244,00 & 246,00 & 1,01 & 0,04730 & 0,00280 & 0,2020 & 0,0120 & 0,03159 & 0,00060 & 0,1214 & 201,19 & 7,17 & 187,00 & 9,90 & 100,00 & 110,00 \\
\hline LMC-075-34 & 217,00 & 93,00 & 0,43 & 0,04910 & 0,00310 & 0,2090 & 0,0130 & 0,03196 & 0,00063 & 0,2084 & 203,07 & 7,18 & 193,00 & 11,00 & 150,00 & 110,00 \\
\hline LMC-075-4 & 437,00 & 608,00 & 1,39 & 0,04920 & 0,00240 & 0,2130 & 0,0110 & 0,03215 & 0,00050 & 0,2867 & 204,24 & 7,16 & 196,00 & 8,80 & 162,00 & 92,00 \\
\hline LMC-075-6 & 538,00 & $1.390,00$ & 2,58 & 0,13120 & 0,00650 & 0,5670 & 0,0270 & 0,03219 & 0,00049 & 0,0564 & 183,72 & 7,60 & 458,00 & 17,00 & $2.079,00$ & 91,00 \\
\hline LMC-075-27 & 50,10 & 34,90 & 0,70 & 0,04930 & 0,00630 & 0,2130 & 0,0260 & 0,03223 & 0,00097 & 0,0718 & 204,72 & 8,51 & 187,00 & 22,00 & 100,00 & 210,00 \\
\hline LMC-075-9 & 377,00 & 407,00 & 1,08 & 0,05120 & 0,00220 & 0,2225 & 0,0094 & 0,03241 & 0,00053 & 0,2228 & 205,37 & 7,16 & 204,40 & 7,70 & 248,00 & 82,00 \\
\hline LMC-075-28 & 274,00 & 378,00 & 1,38 & 0,04500 & 0,00280 & 0,2020 & 0,0130 & 0,03242 & 0,00073 & 0,2718 & 207,01 & 7,79 & 185,00 & 11,00 & 20,00 & 120,00 \\
\hline LMC-075-7 & $3.360,00$ & $5.390,00$ & 1,60 & 0,05960 & 0,00100 & 0,2638 & 0,0055 & 0,03246 & 0,00047 & 0,5698 & 203,54 & 6,57 & 237,80 & 4,40 & 581,00 & 38,00 \\
\hline LMC-075-53 & 139,20 & 133,50 & 0,96 & 0,05750 & 0,00730 & 0,2530 & 0,0300 & 0,03260 & 0,00120 & 0,0039 & 204,94 & 10,35 & 223,00 & 24,00 & 410,00 & 240,00 \\
\hline LMC-075-38 & 838,00 & 525,00 & 0,63 & 0,05140 & 0,00160 & 0,2200 & 0,0073 & 0,03265 & 0,00042 & 0,3093 & 206,82 & 6,56 & 202,10 & 6,00 & 60,00 & 65,00 \\
\hline LMC-075-24 & 533,00 & 974,00 & 1,83 & 0,12620 & 0,00560 & 0,5800 & 0,0300 & 0,03267 & 0,00075 & 0,4087 & 187,73 & 8,40 & 461,00 & 19,00 & $2.027,00$ & 79,00 \\
\hline LMC-075-39 & $1.620,00$ & $1.131,00$ & 0,70 & 0,04910 & 0,00120 & 0,2114 & 0,0055 & 0,03291 & 0,00057 & 0,4626 & 209,04 & 7,15 & 194,20 & 4,70 & 161,00 & 51,00 \\
\hline LMC-075-17 & 832,00 & 848,00 & 1,02 & 0,07410 & 0,00400 & 0,3520 & 0,0210 & 0,03302 & 0,00050 & 0,3099 & 203,25 & 7,28 & 300,00 & 15,00 & 970,00 & 110,00 \\
\hline LMC-075-3 & $5.410,00$ & $2.1200,00$ & 3,92 & 0,06110 & 0,00140 & 0,2736 & 0,0068 & 0,03365 & 0,00034 & 0,1671 & 210,53 & 6,61 & 245,20 & 5,40 & 621,00 & 51,00 \\
\hline LMC-075-8 & $1.560,00$ & $4.770,00$ & 3,06 & 0,05500 & 0,00190 & 0,2529 & 0,0089 & 0,03390 & 0,00038 & 0,3161 & 213,70 & 6,59 & 228,30 & 7,20 & 403,00 & 76,00 \\
\hline LMC-075-36 & 419,00 & 345,90 & 0,83 & 0,04730 & 0,00240 & 0,2070 & 0,0110 & 0,03390 & 0,00054 & 0,1649 & 215,74 & 7,18 & 190,60 & 9,00 & 84,00 & 95,00 \\
\hline LMC-075-37 & 154,20 & 160,00 & 1,04 & 0,05020 & 0,00370 & 0,2180 & 0,0160 & 0,03392 & 0,00065 & 0,0679 & 215,10 & 7,82 & 203,00 & 13,00 & 210,00 & 130,00 \\
\hline LMC-075-31 & 131,00 & 76,50 & 0,58 & 0,06470 & 0,00450 & 0,2990 & 0,0210 & 0,03422 & 0,00062 & 0,1171 & 213,09 & 7,86 & 261,00 & 16,00 & 690,00 & 140,00 \\
\hline LMC-075-19 & 318,00 & 46,73 & 0,15 & 0,05050 & 0,00280 & 0,2430 & 0,0140 & 0,03483 & 0,00059 & 0,3449 & 220,72 & 7,81 & 19,00 & 12,00 & 0,00 & 110,00 \\
\hline LMC-075-11 & 157,00 & 151,50 & 0,96 & 0,11810 & 0,00500 & 0,5770 & 0,0260 & 0,03511 & 0,00070 & 0,4470 & 203,87 & 8,34 & 458,00 & 17,00 & $1.915,00$ & 77,00 \\
\hline LMC-075-35 & 756,00 & 552,00 & 0,73 & 0,05040 & 0,00210 & 0,2300 & 0,0110 & 0,03539 & 0,00080 & 0,4967 & 224,26 & 8,41 & 209,20 & 9,30 & 98,00 & 36,00 \\
\hline LMC-075-30 & 415,00 & 414,00 & 1,00 & 0,06410 & 0,00360 & 0,3060 & 0,0170 & 0,03585 & 0,00087 & 0,1854 & 223,30 & 9,05 & 272,00 & 14,00 & 680,00 & 120,00 \\
\hline LMC-075-14 & 412,00 & 525,00 & 1,27 & 0,09170 & 0,00700 & 0,4620 & 0,0380 & 0,03690 & 0,00130 & 0,3101 & 221,79 & 10,45 & 397,00 & 25,00 & $1.450,00$ & 150,00 \\
\hline LMC-075-40 & 734,00 & $1.210,00$ & 1,65 & 0,05530 & 0,00390 & 0,2850 & 0,0230 & 0,03950 & 0,00110 & 0,5007 & 248,47 & 10,30 & 252,00 & 17,00 & 380,00 & 130,00 \\
\hline LMC-075-13 & 756,00 & 234,00 & 0,31 & 0,22800 & 0,01800 & 1,3300 & 0,1400 & 0,04180 & 0,00220 & 0,7130 & 206,46 & 17,20 & 838,00 & 61,00 & $3.020,00$ & 130,00 \\
\hline LMC-075-33 & $1.035,00$ & 939,00 & 0,91 & 0,08270 & 0,00280 & 1,0960 & 0,0970 & 0,10140 & 0,00800 & 0,9262 & 606,18 & 50,26 & 38,00 & 48,00 & $1.259,00$ & 65,00 \\
\hline LMC-075-50 & $1.530,00$ & 563,00 & 0,37 & 0,07962 & 0,00096 & 1,9300 & 0,0360 & 0,17320 & 0,00230 & 0,7447 & $1.022,55$ & 33,91 & $1.090,00$ & 12,00 & $1.183,00$ & 24,00 \\
\hline LMC-075-1 & 714,00 & 216,20 & 0,30 & 0,07730 & 0,00160 & 1,8130 & 0,0420 & 0,17580 & 0,00190 & 0,3960 & $1.040,14$ & 33,51 & $1.047,00$ & 15,00 & $1.119,00$ & 42,00 \\
\hline & & & & & & & & & & & & & ב? & 18,00 & 209, & B8,00 \\
\hline
\end{tabular}


Anexo 1.4. Resultados isotópicos U-Pb en circón de la muestra AMC-0162

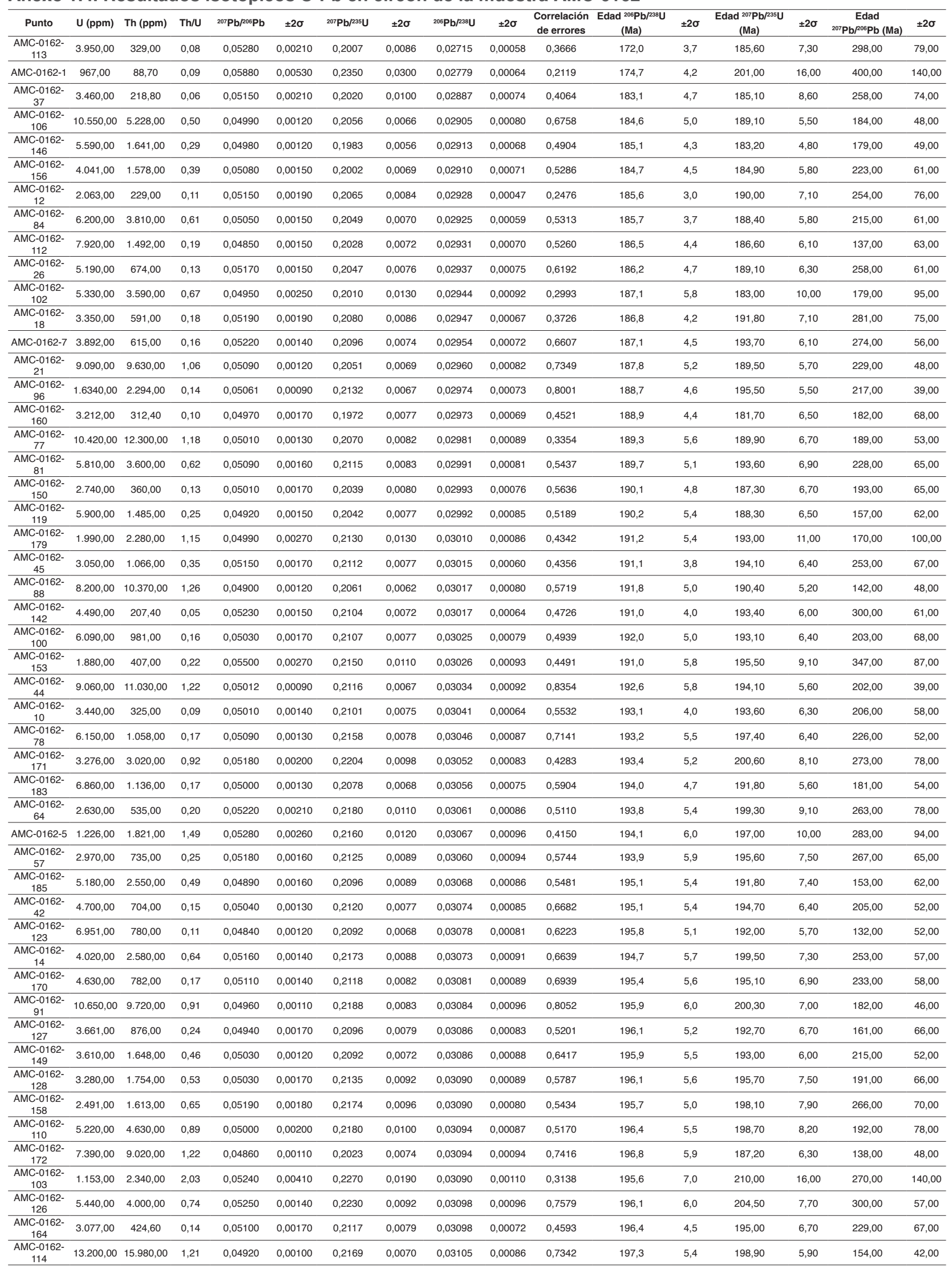




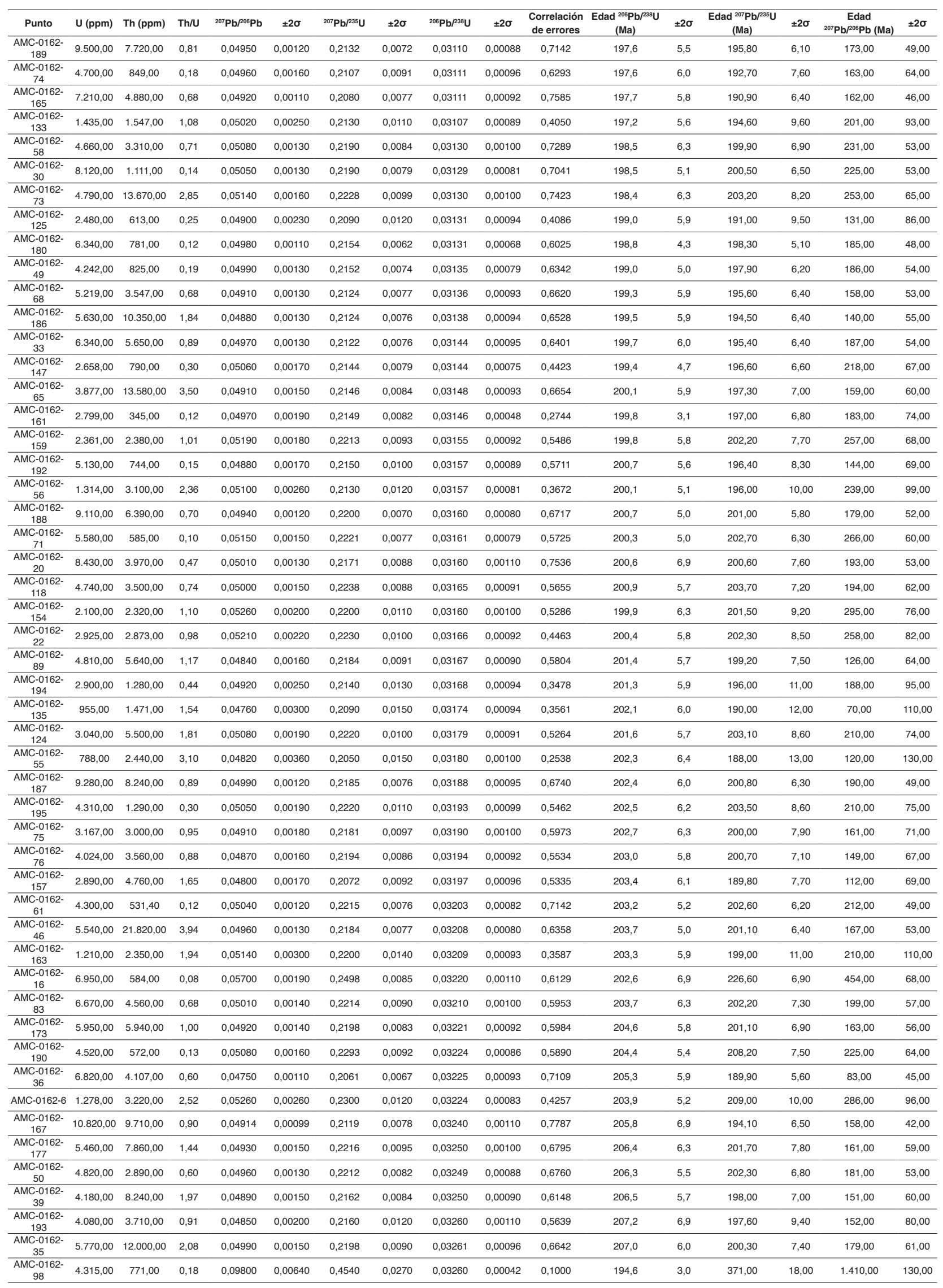




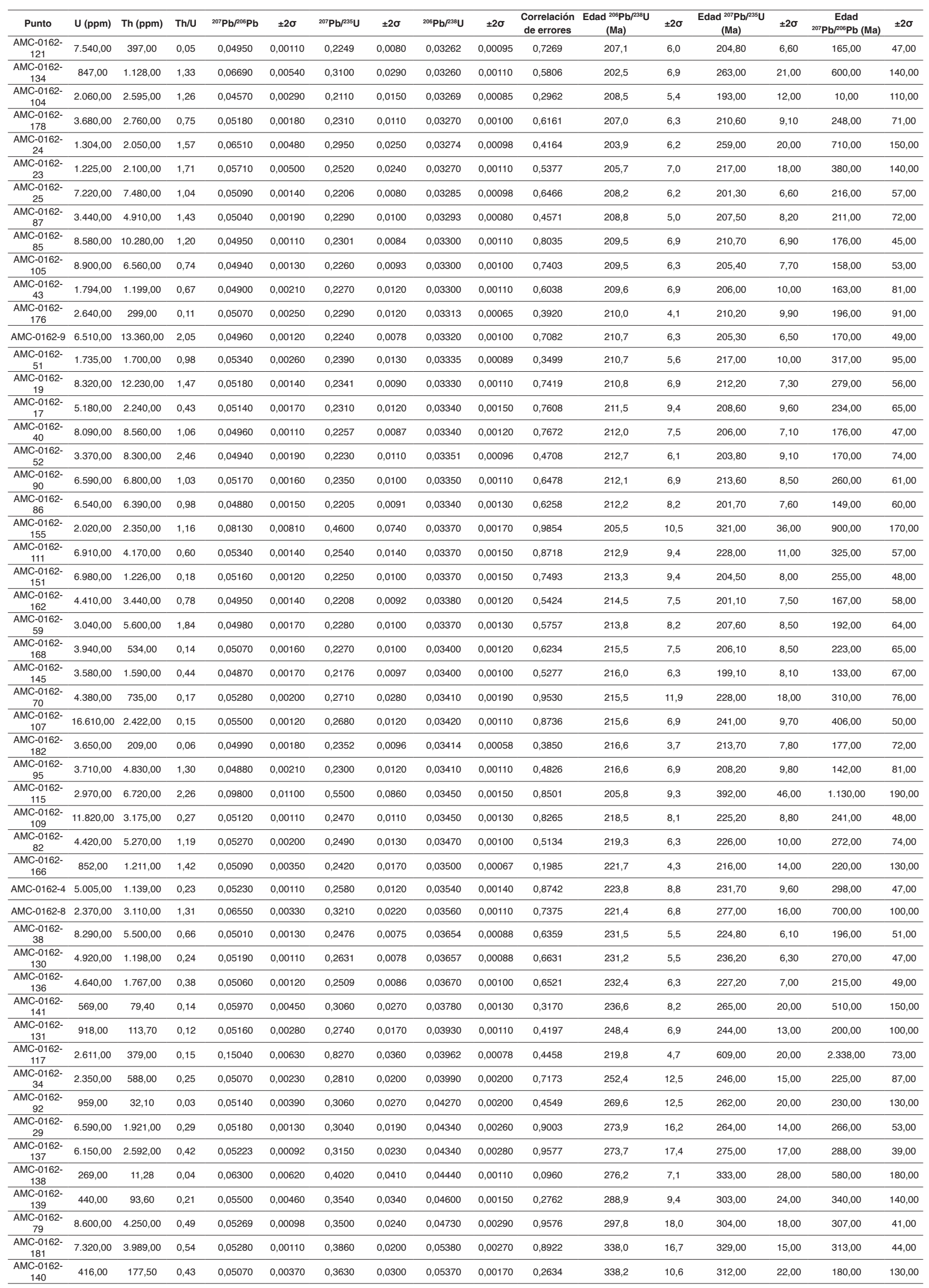




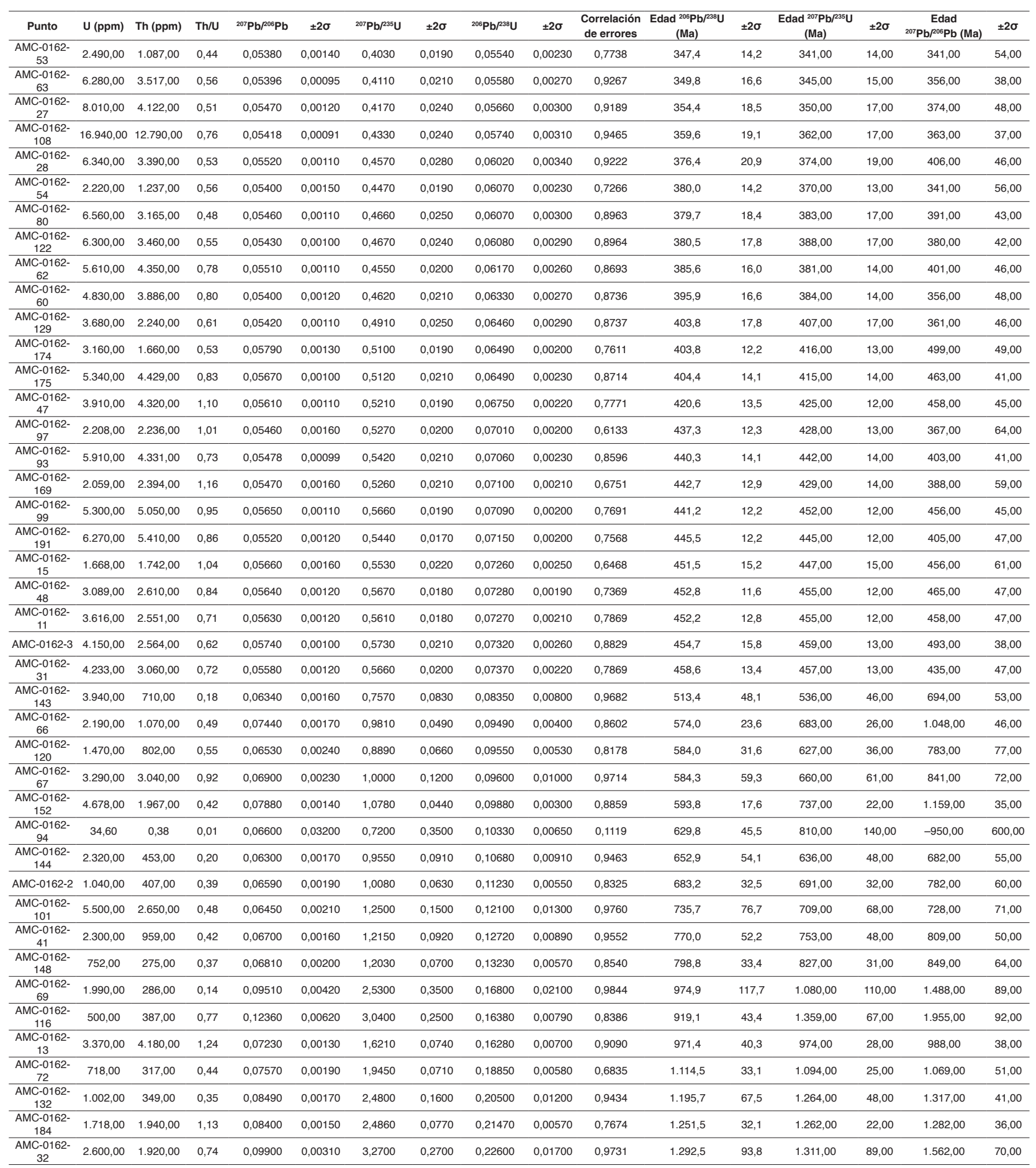


Anexo 1.5. Resultados isotópicos U-Pb en circón de la muestra GZ-6831

\begin{tabular}{|c|c|c|c|c|c|c|c|c|c|c|c|c|c|c|c|c|}
\hline Punto & $\mathrm{U}(\mathrm{ppm})$ & Th (ppm) & $\mathrm{Th} / \mathrm{U}$ & ${ }^{207} \mathrm{~Pb} /{ }^{206} \mathrm{~Pb}$ & $\pm 2 \sigma$ & ${ }^{207} \mathrm{~Pb} /{ }^{235} \mathrm{U}$ & $\pm 2 \sigma$ & ${ }^{206} \mathrm{~Pb} /{ }^{33} \mathrm{U}$ & $\pm 2 \sigma$ & $\begin{array}{c}\text { Correlación } \\
\text { de errores }\end{array}$ & $\begin{array}{c}\text { Edad }{ }^{206} \mathrm{~Pb} /{ }^{238} \mathrm{U} \\
(\mathrm{Ma})\end{array}$ & $\pm 2 \sigma$ & $\begin{array}{c}\text { Edad }^{207} \mathrm{~Pb} /{ }^{235} \mathrm{U} \\
(\mathrm{Ma})\end{array}$ & $\pm 2 \sigma$ & $\begin{array}{c}\text { Edad } \\
{ }^{207} \mathrm{~Pb} /{ }^{206} \mathrm{~Pb} \text { (Ma) }\end{array}$ & $\pm 2 \sigma$ \\
\hline GZ-6831-37 & $1.180,00$ & 728,00 & 0,62 & 0,05070 & 0,00110 & 0,1931 & 0,0043 & 0,02842 & 0,00024 & 0,3138 & 180,43 & 5,07 & 179,50 & 3,70 & 212,00 & 45,00 \\
\hline GZ-6831-42 & 578,00 & 407,00 & 0,70 & 0,05110 & 0,00160 & 0,2024 & 0,0064 & 0,02948 & 0,00028 & 0,1561 & 187,00 & 5,33 & 187,90 & 5,40 & 229,00 & 63,00 \\
\hline GZ-6831-33 & 389,00 & 455,00 & 1,17 & 0,05100 & 0,00220 & 0,2024 & 0,0089 & 0,02952 & 0,00032 & 0,1298 & 187,27 & 5,40 & 186,40 & 7,40 & 231,00 & 84,00 \\
\hline GZ-6831-43 & 617,00 & 564,00 & 0,91 & 0,05100 & 0,00170 & 0,1995 & 0,0065 & 0,02949 & 0,00028 & 0,1909 & 187,08 & 5,27 & 186,30 & 5,50 & 228,00 & 67,00 \\
\hline GZ-6831-34 & 715,00 & $1.374,00$ & 1,92 & 0,05370 & 0,00140 & 0,2101 & 0,0052 & 0,02954 & 0,00024 & 0,1503 & 186,77 & 5,19 & 193,50 & 4,40 & 344,00 & 55,00 \\
\hline GZ-6831-45 & 440,00 & 261,00 & 0,59 & 0,05340 & 0,00210 & 0,2127 & 0,0084 & 0,02981 & 0,00028 & 0,1300 & 188,53 & 5,34 & 197,00 & 6,90 & 307,00 & 80,00 \\
\hline GZ-6831-41 & 373,00 & 296,80 & 0,80 & 0,05160 & 0,00210 & 0,2080 & 0,0083 & 0,02994 & 0,00031 & 0,1079 & 189,77 & 5,46 & 191,80 & 6,90 & 251,00 & 82,00 \\
\hline GZ-6831-5 & 843,00 & 435,00 & 0,52 & 0,05150 & 0,00150 & 0,2146 & 0,0064 & 0,03003 & 0,00032 & 0,3519 & 190,36 & 5,45 & 197,30 & 5,40 & 260,00 & 60,00 \\
\hline GZ-6831-14 & $1.173,00$ & $2.880,00$ & 2,46 & 0,06150 & 0,00380 & 0,2490 & 0,0150 & 0,03008 & 0,00039 & 0,0511 & 188,30 & 5,67 & 223,00 & 12,00 & 520,00 & 110,00 \\
\hline GZ-6831-2 & 637,00 & 633,10 & 0,99 & 0,05130 & 0,00180 & 0,2163 & 0,0076 & 0,03023 & 0,00032 & 0,1410 & 191,66 & 5,52 & 197,90 & 6,30 & 235,00 & 71,00 \\
\hline GZ-6831-31 & 435,00 & 419,00 & 0,96 & 0,05520 & 0,00320 & 0,2250 & 0,0150 & 0,03024 & 0,00034 & 0,6274 & 190,80 & 5,60 & 198,00 & 10,00 & 282,00 & 88,00 \\
\hline GZ-6831-9 & 790,00 & $1.310,00$ & 1,66 & 0,05040 & 0,00170 & 0,2093 & 0,0073 & 0,03028 & 0,00029 & 0,1347 & 192,19 & 5,45 & 193,50 & 6,00 & 220,00 & 69,00 \\
\hline GZ-6831-18 & 880,00 & $1.085,00$ & 1,23 & 0,05180 & 0,00170 & 0,2151 & 0,0077 & 0,03029 & 0,00034 & 0,3627 & 191,92 & 5,57 & 196,80 & 6,40 & 281,00 & 67,00 \\
\hline GZ-6831-26 & 474,00 & 497,00 & 1,05 & 0,05010 & 0,00190 & 0,2056 & 0,0079 & 0,03034 & 0,00031 & 0,1208 & 192,64 & 5,52 & 189,80 & 6,70 & 212,00 & 77,00 \\
\hline GZ-6831-39 & 129,30 & 176,50 & 1,37 & 0,04700 & 0,00320 & 0,1930 & 0,0120 & 0,03036 & 0,00048 & 0,0142 & 193,51 & 6,00 & 176,00 & 11,00 & 50,00 & 110,00 \\
\hline GZ-6831-36 & 408,00 & 363,00 & 0,89 & 0,05070 & 0,00200 & 0,2066 & 0,0086 & 0,03042 & 0,00029 & 0,2029 & 193,00 & 5,46 & 191,70 & 7,10 & 228,00 & 80,00 \\
\hline GZ-6831-32 & 722,00 & $1.350,00$ & 1,87 & 0,05350 & 0,00160 & 0,2165 & 0,0066 & 0,03046 & 0,00026 & 0,4188 & 192,58 & 5,39 & 199,30 & 5,50 & 328,00 & 61,00 \\
\hline GZ-6831-21 & 459,00 & 374,00 & 0,81 & 0,04770 & 0,00210 & 0,1975 & 0,0085 & 0,03050 & 0,00033 & 0,0373 & 194,22 & 5,60 & 182,50 & 7,10 & 96,00 & 83,00 \\
\hline GZ-6831-44 & 426,00 & 661,00 & 1,55 & 0,05210 & 0,00210 & 0,2085 & 0,0080 & 0,03050 & 0,00037 & 0,1244 & 193,17 & 5,64 & 191,80 & 6,80 & 266,00 & 79,00 \\
\hline GZ-6831-8 & 325,10 & 313,60 & 0,96 & 0,05090 & 0,00230 & 0,2150 & 0,0096 & 0,03057 & 0,00036 & 0,0867 & 193,89 & 5,65 & 196,20 & 8,00 & 241,00 & 89,00 \\
\hline GZ-6831-16 & 738,00 & 823,00 & 1,12 & 0,05430 & 0,00230 & 0,2240 & 0,0100 & 0,03065 & 0,00035 & 0,1793 & 193,58 & 5,64 & 204,30 & 8,40 & 365,00 & 88,00 \\
\hline GZ-6831-46 & 436,00 & 315,00 & 0,72 & 0,05460 & 0,00210 & 0,2285 & 0,0090 & 0,03068 & 0,00037 & 0,1713 & 193,69 & 5,70 & 208,90 & 7,40 & 397,00 & 80,00 \\
\hline GZ-6831-13 & 429,00 & 404,00 & 0,94 & 0,05150 & 0,00310 & 0,2110 & 0,0120 & 0,03070 & 0,00045 & 0,1000 & 194,56 & 5,92 & 194,00 & 10,00 & 230,00 & 110,00 \\
\hline GZ-6831-29 & 631,00 & 807,00 & 1,28 & 0,05130 & 0,00150 & 0,2125 & 0,0061 & 0,03071 & 0,00027 & 0,2003 & 194,68 & 5,45 & 195,50 & 5,00 & 242,00 & 60,00 \\
\hline GZ-6831-10 & 576,00 & 517,00 & 0,90 & 0,05590 & 0,00220 & 0,2337 & 0,0090 & 0,03072 & 0,00032 & 0,1243 & 193,63 & 5,58 & 212,50 & 7,50 & 395,00 & 80,00 \\
\hline GZ-6831-24 & 348,00 & 299,00 & 0,86 & 0,05200 & 0,00240 & 0,2160 & 0,0100 & 0,03074 & 0,00037 & 0,1197 & 194,69 & 5,72 & 197,70 & 8,30 & 280,00 & 92,00 \\
\hline GZ-6831-19 & 672,00 & 388,00 & 0,58 & 0,05400 & 0,00190 & 0,2249 & 0,0078 & 0,03081 & 0,00037 & 0,0975 & 194,65 & 5,70 & 205,00 & 6,40 & 349,00 & 69,00 \\
\hline GZ-6831-6 & 310,00 & 198,80 & 0,64 & 0,04880 & 0,00230 & 0,2047 & 0,0096 & 0,03092 & 0,00038 & 0,2111 & 196,60 & 5,79 & 188,20 & 8,00 & 133,00 & 89,00 \\
\hline GZ-6831-35 & 456,00 & 907,00 & 1,99 & 0,05880 & 0,00210 & 0,2440 & 0,0092 & 0,03096 & 0,00035 & 0,3187 & 194,42 & 5,69 & 220,40 & 7,50 & 530,00 & 73,00 \\
\hline GZ-6831-7 & 248,00 & 142,80 & 0,58 & 0,04790 & 0,00280 & 0,2000 & 0,0120 & 0,03103 & 0,00041 & 0,1207 & 197,51 & 5,92 & 182,80 & 9,90 & 90,00 & 110,00 \\
\hline GZ-6831-11 & 639,00 & 549,00 & 0,86 & 0,05520 & 0,00250 & 0,2350 & 0,0110 & 0,03103 & 0,00035 & 0,1687 & 195,73 & 5,71 & 212,70 & 8,80 & 400,00 & 92,00 \\
\hline GZ-6831-40 & 258,00 & 217,00 & 0,84 & 0,05080 & 0,00250 & 0,2103 & 0,0098 & 0,03107 & 0,00043 & 0,0428 & 197,06 & 5,90 & 193,90 & 8,30 & 248,00 & 97,00 \\
\hline GZ-6831-15 & 771,00 & 944,00 & 1,22 & 0,05320 & 0,00200 & 0,2235 & 0,0083 & 0,03119 & 0,00028 & 0,0757 & 197,22 & 5,58 & 204,20 & 6,90 & 294,00 & 76,00 \\
\hline GZ-6831-22 & 481,00 & 542,00 & 1,13 & 0,05100 & 0,00220 & 0,2151 & 0,0090 & 0,03121 & 0,00035 & 0,1157 & 197,89 & 5,71 & 197,10 & 7,40 & 230,00 & 82,00 \\
\hline GZ-6831-27 & $2.970,00$ & $1.1730,00$ & 3,95 & 0,05464 & 0,00091 & 0,2281 & 0,0049 & 0,03139 & 0,00035 & 0,6730 & 198,12 & 5,75 & 208,40 & 4,10 & 398,00 & 37,00 \\
\hline GZ-6831-1 & 459,00 & 473,00 & 1,03 & 0,05230 & 0,00220 & 0,2287 & 0,0097 & 0,03144 & 0,00036 & 0,1746 & 199,01 & 5,77 & 208,50 & 8,20 & 286,00 & 87,00 \\
\hline GZ-6831-23 & 255,00 & 172,10 & 0,67 & 0,05220 & 0,00310 & 0,2240 & 0,0130 & 0,03151 & 0,00044 & 0,1367 & 199,47 & 6,04 & 203,00 & 11,00 & 270,00 & 110,00 \\
\hline GZ-6831-4 & 410,00 & 559,00 & 1,36 & 0,06510 & 0,00300 & 0,2930 & 0,0160 & 0,03159 & 0,00057 & 0,4727 & 196,77 & 6,37 & 259,00 & 12,00 & 789,00 & 98,00 \\
\hline GZ-6831-17 & 510,00 & 591,00 & 1,16 & 0,05340 & 0,00260 & 0,2260 & 0,0110 & 0,03158 & 0,00038 & 0,0655 & 199,61 & 5,91 & 206,50 & 8,80 & 327,00 & 94,00 \\
\hline GZ-6831-3 & 184,00 & 198,00 & 1,08 & 0,04670 & 0,00440 & 0,2000 & 0,0190 & 0,03159 & 0,00059 & 0,1011 & 201,34 & 6,48 & 193,00 & 15,00 & 100,00 & 150,00 \\
\hline GZ-6831-25 & 534,00 & 459,00 & 0,86 & 0,04960 & 0,00190 & 0,2122 & 0,0083 & 0,03172 & 0,00036 & 0,1871 & 201,44 & 5,84 & 194,70 & 7,00 & 176,00 & 77,00 \\
\hline GZ-6831-12 & 301,00 & 259,70 & 0,86 & 0,05910 & 0,00390 & 0,2490 & 0,0160 & 0,03202 & 0,00047 & 0,1230 & 200,93 & 6,18 & 231,00 & 13,00 & 510,00 & 130,00 \\
\hline GZ-6831-20 & 588,00 & 546,00 & 0,93 & 0,04930 & 0,00190 & 0,2255 & 0,0094 & 0,03467 & 0,00051 & 0,2843 & 220,05 & 6,40 & 207,80 & 7,80 & 167,00 & 76,00 \\
\hline GZ-6831-38 & 457,00 & 51,70 & 0,11 & 0,05240 & 0,00140 & 0,3028 & 0,0080 & 0,04254 & 0,00053 & 0,3189 & 268,30 & 7,63 & 267,70 & 6,20 & 292,00 & 54,00 \\
\hline GZ-6831-30 & 383,00 & 360,00 & 0,94 & 0,05270 & 0,00180 & 0,3200 & 0,0120 & 0,04568 & 0,00073 & 0,4443 & 287,72 & 8,86 & 282,60 & 9,60 & 285,00 & 69,00 \\
\hline GZ-6831-28 & 562,00 & 253,00 & 0,45 & 0,07050 & 0,00120 & 1,4280 & 0,0270 & 0,15090 & 0,00120 & 0,2802 & 904,68 & 25,18 & 902,00 & 11,00 & 936,00 & 35,00 \\
\hline
\end{tabular}


Anexo 1.6. Resultados isotópicos U-Pb en circón de la muestra MIA-636

\begin{tabular}{|c|c|c|c|c|c|c|c|c|c|c|c|c|c|c|c|c|c|}
\hline Punto & $\mathrm{U}(\mathrm{ppm}$ & Th (ppm) & $\mathrm{Th} / \mathrm{U}$ & ${ }^{207} \mathrm{~Pb} / 206 \mathrm{~Pb}$ & $\pm 2 \sigma$ & ${ }^{207} \mathrm{~Pb} /{ }^{235} \mathrm{U}$ & $\pm 2 \sigma$ & ${ }^{206} \mathrm{~Pb} /{ }^{238} \mathrm{U}$ & $\pm 2 \sigma$ & $\begin{array}{c}\text { Correlación } \\
\text { de errores }\end{array}$ & $\pm 2 \sigma$ & ${ }^{206} \mathrm{~Pb} /{ }^{238} \mathrm{U}$ & $\pm 2 \sigma$ & ${ }^{207} \mathrm{~Pb} /{ }^{235} \mathrm{U}$ & $\pm 2 \sigma$ & ${ }^{207} \mathrm{~Pb} / 206 \mathrm{~Pb}$ & $\pm 2 \sigma$ \\
\hline Zircon-99 & 430 & 2.570 & 5,98 & 0,0722 & 0,0047 & 0,2310 & 0,0170 & 0,0221 & 0,0015 & 0,5588 & 0,0009 & 140,8 & 9,7 & 210,0 & 14,0 & 970,0 & 140,0 \\
\hline Zircon-071 & 178 & 132 & 0,74 & 0,0645 & 0,0073 & 0,3570 & 0,0350 & 0,0397 & 0,0010 & 0,0693 & 0,0007 & 250,8 & 6,1 & 315,0 & 25,0 & 690,0 & 200,0 \\
\hline Zircon-085 & 315 & 140 & 0,44 & 0,0876 & 0,0034 & 1,4510 & 0,0870 & 0,1199 & 0,0048 & 0,9021 & 0,0034 & 729 & 28,0 & 909,0 & 37,0 & $1.366,0$ & 76,0 \\
\hline Zircon-075 & 164 & 230 & 1,40 & 0,0630 & 0,0064 & 0,2480 & 0,0220 & 0,0290 & 0,0008 & 0,0924 & 0,0006 & 184,1 & 5,1 & 223,0 & 18,0 & 690,0 & 210,0 \\
\hline Zircon-93 & 165 & 216 & 1,31 & 0,0630 & 0,0120 & 0,2940 & 0,0600 & 0,0348 & 0,0007 & 0,1009 & 0,0010 & 220,5 & 4,5 & 264,0 & 41,0 & 710,0 & 290,0 \\
\hline Zircon-079 & 22,6 & 20,3 & 0,90 & 0,0670 & 0,0120 & 0,2800 & 0,0480 & 0,0320 & 0,0019 & 0,0261 & 0,0014 & 205 & 12,0 & 242,0 & 38,0 & 710,0 & 380,0 \\
\hline Zircon-076 & 149 & 145 & 0,97 & 0,0548 & 0,0048 & 0,2550 & 0,0210 & 0,0324 & 0,0007 & 0,0183 & 0,0005 & 205,2 & 4,6 & 235,0 & 17,0 & 420,0 & 190,0 \\
\hline Zircon-082 & 526 & 458 & 0,87 & 0,0578 & 0,0034 & 0,2610 & 0,0160 & 0,0327 & 0,0005 & 0,0993 & 0,0005 & 207,2 & 3,0 & 235,0 & 12,0 & 490,0 & 120,0 \\
\hline Zircon-081 & 186 & 135 & 0,73 & 0,0566 & 0,0040 & 0,2510 & 0,0170 & 0,0316 & 0,0007 & 0,0490 & 0,0005 & 200,4 & 4,1 & 227,0 & 14,0 & 480,0 & 150,0 \\
\hline Zircon-95 & 258 & 530 & 2,05 & 0,0571 & 0,0052 & 0,2350 & 0,0220 & 0,0301 & 0,0006 & 0,1677 & 0,0004 & 191,3 & 3,6 & 213,0 & 17,0 & 480,0 & 160,0 \\
\hline Zircon-084 & 136 & 100 & 0,74 & 0,0510 & 0,0050 & 0,2600 & 0,1300 & 0,0360 & 0,0110 & 0,1207 & 0,0010 & 226 & 64,0 & 231,0 & 78,0 & 230,0 & 180,0 \\
\hline $\begin{array}{c}\text { Zircon-102 } \\
\text { MIA-636 }\end{array}$ & 730 & 48,9 & 0,07 & 0,0713 & 0,0026 & 1,5080 & 0,0590 & 0,1509 & 0,0023 & 0,3432 & 0,0020 & 906 & 13,0 & 933,0 & 25,0 & 962,0 & 72,0 \\
\hline Zircon-94 & 916 & 755 & 0,82 & 0,0504 & 0,0022 & 0,2210 & 0,0100 & 0,0314 & 0,0003 & 0,1240 & 0,0004 & 199,1 & 1,8 & 202,8 & 8,7 & 200,0 & 100,0 \\
\hline Zircon-078 & 204 & 198 & 0,97 & 0,0520 & 0,0045 & 0,2270 & 0,0180 & 0,0315 & 0,0007 & 0,0607 & 0,0005 & 199,7 & 4,2 & 206,0 & 15,0 & 260,0 & 180,0 \\
\hline Zircon-090 & 176 & 159 & 0,90 & 0,0520 & 0,0038 & 0,2310 & 0,0180 & 0,0317 & 0,0007 & 0,2342 & 0,0005 & 201 & 4,3 & 212,0 & 14,0 & 300,0 & 140,0 \\
\hline Zircon-97 & 182 & 212 & 1,16 & 0,0524 & 0,0043 & 0,2290 & 0,0190 & 0,0317 & 0,0006 & 0,0388 & 0,0005 & 201,2 & 4,0 & 208,0 & 16,0 & 230,0 & 170,0 \\
\hline Zircon-98 & 168 & 188 & 1,12 & 0,0524 & 0,0039 & 0,2340 & 0,0240 & 0,0318 & 0,0018 & 0,1633 & 0,0005 & 202 & 11,0 & 212,0 & 19,0 & 270,0 & 160,0 \\
\hline Zircon-100 & 45,6 & 47,1 & 1,03 & 0,0537 & 0,0060 & 0,2390 & 0,0270 & 0,0319 & 0,0011 & 0,0948 & 0,0007 & 202,1 & 6,8 & 215,0 & 22,0 & 290,0 & 240,0 \\
\hline Zircon-101 & 171 & 126 & 0,74 & 0,0480 & 0,0042 & 0,2130 & 0,0180 & 0,0320 & 0,0007 & 0,0554 & 0,0006 & 202,8 & 4,5 & 195,0 & 15,0 & 60,0 & 180,0 \\
\hline Zircon-069 & 103 & 96 & 0,93 & 0,0531 & 0,0053 & 0,2370 & 0,0200 & 0,0320 & 0,0008 & 0,0793 & 0,0006 & 202,9 & 4,7 & 215,0 & 17,0 & 310,0 & 180,0 \\
\hline Zircon-92 & 854 & 379 & 0,44 & 0,0521 & 0,0025 & 0,2310 & 0,0110 & 0,0322 & 0,0004 & 0,0594 & 0,0005 & 204,1 & 2,6 & 211,0 & 9,2 & 270,0 & 110,0 \\
\hline Zircon-072 & 781 & 682 & 0,87 & 0,0514 & 0,0023 & 0,2320 & 0,0110 & 0,0324 & 0,0005 & 0,0034 & 0,0004 & 205,3 & 3,1 & 211,2 & 9,4 & 240,0 & 100,0 \\
\hline Zircon-96 & 1.550 & 1.360 & 0,88 & 0,0501 & 0,0023 & 0,2260 & 0,0120 & 0,0325 & 0,0010 & 0,0550 & 0,0006 & 206 & 6,2 & 207,0 & 10,0 & 190,0 & 100,0 \\
\hline Zircon-089 & 359 & 326 & 0,91 & 0,0484 & 0,0028 & 0,2220 & 0,0140 & 0,0327 & 0,0005 & 0,1441 & 0,0005 & 207,3 & 2,9 & 203,0 & 11,0 & 120,0 & 130,0 \\
\hline Zircon-083 & 98 & 132 & 1,35 & 0,0506 & 0,0054 & 0,2330 & 0,0250 & 0,0329 & 0,0011 & 0,1120 & 0,0006 & 208,9 & 6,6 & 210,0 & 20,0 & 200,0 & 220,0 \\
\hline Zircon-091 & 214 & 205 & 0,96 & 0,0528 & 0,0039 & 0,2430 & 0,0180 & 0,0337 & 0,0006 & 0,3887 & 0,0005 & 213,5 & 4,0 & 220,0 & 15,0 & 280,0 & 160,0 \\
\hline Zircon-080 & 58,6 & 56,1 & 0,96 & 0,0515 & 0,0062 & 0,2380 & 0,0280 & 0,0337 & 0,0010 & 0,1111 & 0,0008 & 213,8 & 6,4 & 214,0 & 23,0 & 210,0 & 240,0 \\
\hline Zircon-074 & 590 & 409 & 0,69 & 0,0528 & 0,0028 & 0,2480 & 0,0160 & 0,0339 & 0,0008 & 0,0781 & 0,0006 & 214,8 & 5,0 & 225,0 & 13,0 & 330,0 & 120,0 \\
\hline Zircon-087 & 1.000 & 609 & 0,61 & 0,0493 & 0,0022 & 0,2310 & 0,0110 & 0,0339 & 0,0003 & 0,0978 & 0,0004 & 215,1 & 1,9 & 210,6 & 9,0 & 150,0 & 100,0 \\
\hline Zircon-077 & 302 & 313 & 1,04 & 0,0490 & 0,0029 & 0,2370 & 0,0150 & 0,0345 & 0,0005 & 0,0205 & 0,0005 & 219,4 & 2,9 & 216,0 & 12,0 & 150,0 & 120,0 \\
\hline Zircon-073 & 464 & 109 & 0,23 & 0,0665 & 0,0027 & 0,8490 & 0,0390 & 0,0927 & 0,0010 & 0,3952 & 0,0018 & 571,7 & 6,0 & 623,0 & 21,0 & 833,0 & 83,0 \\
\hline Zircon-086 & 151 & 80,3 & 0,53 & 0,0849 & 0,0032 & 2,6500 & 0,1200 & 0,2253 & 0,0048 & 0,7164 & 0,0029 & 1.309 & 25,0 & $1.314,0$ & 34,0 & $1.316,0$ & 76,0 \\
\hline
\end{tabular}


Anexo 1.7. Resultados isotópicos U-Pb en circón de la muestra AMC-0144

\begin{tabular}{|c|c|c|c|c|c|c|c|c|c|c|c|c|c|c|c|c|c|c|}
\hline Punto & $U(\mathrm{ppm})$ & Th (ppm) & $\mathrm{Th} / \mathrm{U}$ & ${ }^{207} \mathrm{~Pb} /{ }^{206} \mathrm{~Pb}$ & $\pm 2 \sigma$ & ${ }^{207} \mathrm{~Pb} /{ }^{235} \mathrm{U}$ & $\pm 2 \sigma$ & ${ }^{206} \mathrm{~Pb} /{ }^{238} \mathrm{U}$ & $\pm 2 \sigma$ & $\begin{array}{c}\text { Correlación } \\
\text { de errores }\end{array}$ & ${ }^{208} \mathrm{~Pb} /{ }^{232} \mathrm{Th}$ & $\pm 2 \sigma$ & ${ }^{206} \mathrm{~Pb} /{ }^{33} \mathrm{U}$ & $\pm 2 \sigma$ & ${ }^{207} \mathrm{~Pb} /{ }^{235} \mathrm{U}$ & $\pm 2 \sigma$ & ${ }^{207} \mathrm{~Pb} /{ }^{206} \mathrm{~Pb}$ & $\pm 2 \sigma$ \\
\hline Zircon-007 & 680 & 570 & 0,84 & 0,1143 & 0,0092 & 0,3370 & 0,0460 & 0,0228 & 0,0016 & 0,43 & 0,0084 & 0,0010 & 146,0 & 10,0 & 290,0 & 30,0 & 1810,0 & 130,0 \\
\hline Zircon-009 & 293 & 266 & 0,91 & 0,0744 & 0,0054 & 0,2970 & 0,0200 & 0,0301 & 0,0006 & $-0,14$ & 0,0105 & 0,0005 & 191,1 & 3,6 & 263,0 & 15,0 & 1040,0 & 130,0 \\
\hline Zircon-011 & 360 & 350 & 0,97 & 0,1370 & 0,0110 & 0,6720 & 0,0620 & 0,0358 & 0,0015 & 0,42 & 0,0175 & 0,0014 & 226,8 & 9,2 & 520,0 & 39,0 & 2170,0 & 130,0 \\
\hline Zircon-021 & 578 & 890 & 1,54 & 0,0472 & 0,0024 & 0,2110 & 0,0110 & 0,0324 & 0,0004 & 0,17 & 0,0098 & 0,0004 & 205,2 & 2,6 & 194,4 & 9,4 & 60,0 & 110,0 \\
\hline Zircon-022 & 188 & 155 & 0,82 & 0,0620 & 0,0043 & 0,2790 & 0,0190 & 0,0327 & 0,0006 & $-0,13$ & 0,0113 & 0,0006 & 207,5 & 3,5 & 249,0 & 15,0 & 620,0 & 150,0 \\
\hline Zircon-034 & 392 & 332 & 0,85 & 0,0721 & 0,0078 & 0,3110 & 0,0390 & 0,0316 & 0,0006 & $-0,14$ & 0,0118 & 0,0009 & 200,3 & 4,0 & 274,0 & 27,0 & 960,0 & 160,0 \\
\hline Zircon-002 & 610 & 28 & 0,05 & 0,0668 & 0,0091 & 0,3000 & 0,1700 & 0,0332 & 0,0096 & 0,42 & 0,0440 & 0,0420 & 210,0 & 58,0 & 270,0 & 100,0 & 800,0 & 200,0 \\
\hline Zircon-025 & 230 & 232 & 1,01 & 0,0638 & 0,0050 & 0,2820 & 0,0220 & 0,0318 & 0,0006 & 0,33 & 0,0109 & 0,0007 & 201,9 & 3,9 & 254,0 & 17,0 & 710,0 & 160,0 \\
\hline $\begin{array}{l}\text { Zircon-001 } \\
\text { AMC- }\end{array}$ & 335 & 269 & 0,80 & 0,0498 & 0,0025 & 0,2120 & 0,0110 & 0,0314 & 0,0005 & 0,20 & 0,0100 & 0,0005 & 199,1 & 3,2 & 194,9 & 9,3 & 200,0 & 110,0 \\
\hline Zircon-008 & 274 & 268 & 0,98 & 0,0489 & 0,0033 & 0,2210 & 0,0150 & 0,0330 & 0,0006 & 0,15 & 0,0104 & 0,0005 & 209,0 & 4,0 & 204,0 & 12,0 & 140,0 & 140,0 \\
\hline Zircon-013 & 410 & 269 & 0,66 & 0,0501 & 0,0036 & 0,2070 & 0,0150 & 0,0299 & 0,0006 & 0,23 & 0,0088 & 0,0006 & 189,6 & 3,9 & 191,0 & 13,0 & 220,0 & 150,0 \\
\hline Zircon-014 & 295 & 286 & 0,97 & 0,0520 & 0,0029 & 0,2290 & 0,0120 & 0,0323 & 0,0006 & 0,08 & 0,0101 & 0,0005 & 205,0 & 3,7 & 209,0 & 10,0 & 270,0 & 120,0 \\
\hline Zircon-015 & 369 & 344 & 0,93 & 0,0494 & 0,0032 & 0,2140 & 0,0130 & 0,0318 & 0,0005 & 0,06 & 0,0101 & 0,0004 & 201,6 & 3,4 & 198,0 & 11,0 & 180,0 & 140,0 \\
\hline Zircon-016 & 326 & 575 & 1,76 & 0,0485 & 0,0033 & 0,2120 & 0,0140 & 0,0317 & 0,0006 & 0,03 & 0,0098 & 0,0004 & 201,1 & 3,7 & 195,0 & 12,0 & 140,0 & 150,0 \\
\hline Zircon-017 & 234 & 198 & 0,85 & 0,0498 & 0,0038 & 0,2290 & 0,0170 & 0,0327 & 0,0006 & 0,12 & 0,0104 & 0,0005 & 207,2 & 3,5 & 208,0 & 14,0 & 230,0 & 160,0 \\
\hline Zircon-019 & 1.700 & 1.300 & 0,76 & 0,0533 & 0,0061 & 0,2320 & 0,0300 & 0,0315 & 0,0009 & 0,01 & 0,0107 & 0,0006 & 199,7 & 5,5 & 211,0 & 24,0 & 270,0 & 200,0 \\
\hline Zircon-020 & 148 & 105,8 & 0,71 & 0,0504 & 0,0038 & 0,2300 & 0,0180 & 0,0328 & 0,0008 & 0,26 & 0,0106 & 0,0006 & 208,2 & 5,1 & 214,0 & 14,0 & 250,0 & 150,0 \\
\hline Zircon-023 & 368 & 302 & 0,82 & 0,0490 & 0,0027 & 0,2150 & 0,0120 & 0,0317 & 0,0004 & 0,01 & 0,0101 & 0,0004 & 201,0 & 2,8 & 197,7 & 9,7 & 150,0 & 110,0 \\
\hline Zircon-024 & 496 & 750 & 1,51 & 0,0524 & 0,0033 & 0,2270 & 0,0140 & 0,0310 & 0,0005 & 0,25 & 0,0097 & 0,0004 & 197,1 & 3,2 & 207,0 & 11,0 & 310,0 & 140,0 \\
\hline Zircon-026 & 530 & 539 & 1,02 & 0,0505 & 0,0027 & 0,2260 & 0,0120 & 0,0320 & 0,0005 & 0,02 & 0,0097 & 0,0004 & 202,9 & 3,3 & 208,0 & 10,0 & 230,0 & 120,0 \\
\hline Zircon-027 & 454 & 532 & 1,17 & 0,0483 & 0,0027 & 0,2130 & 0,0120 & 0,0317 & 0,0006 & 0,07 & 0,0098 & 0,0004 & 201,3 & 3,6 & 196,0 & 10,0 & 100,0 & 120,0 \\
\hline Zircon-028 & 312 & 233 & 0,75 & 0,0517 & 0,0034 & 0,2310 & 0,0150 & 0,0327 & 0,0005 & 0,02 & 0,0104 & 0,0005 & 207,3 & 3,2 & 210,0 & 12,0 & 240,0 & 140,0 \\
\hline Zircon-029 & 724 & 920 & 1,27 & 0,0503 & 0,0024 & 0,2170 & 0,0110 & 0,0313 & 0,0004 & 0,35 & 0,0096 & 0,0004 & 198,8 & 2,4 & 198,9 & 9,5 & 210,0 & 100,0 \\
\hline Zircon-030 & 401 & 406 & 1,01 & 0,0492 & 0,0033 & 0,2140 & 0,0130 & 0,0310 & 0,0007 & 0,20 & 0,0098 & 0,0004 & 196,7 & 4,4 & 197,0 & 11,0 & 170,0 & 130,0 \\
\hline Zircon-031 & 371 & 267 & 0,72 & 0,0498 & 0,0028 & 0,2140 & 0,0140 & 0,0315 & 0,0007 & 0,34 & 0,0101 & 0,0004 & 199,6 & 4,2 & 198,0 & 11,0 & 180,0 & 120,0 \\
\hline Zircon-032 & 388 & 274 & 0,71 & 0,0510 & 0,0029 & 0,2270 & 0,0130 & 0,0321 & 0,0006 & 0,06 & 0,0100 & 0,0005 & 203,8 & 3,6 & 209,0 & 11,0 & 240,0 & 120,0 \\
\hline Zircon-033 & 346 & 323 & 0,93 & 0,0517 & 0,0037 & 0,2260 & 0,0160 & 0,0313 & 0,0006 & 0,07 & 0,0101 & 0,0004 & 198,8 & 3,6 & 206,0 & 13,0 & 260,0 & 140,0 \\
\hline $\begin{array}{c}\text { Zircon-035 } \\
\text { AMC- }\end{array}$ & 569 & 738 & 1,30 & 0,0508 & 0,0028 & 0,2270 & 0,0120 & 0,0329 & 0,0007 & 0,06 & 0,0102 & 0,0004 & 208,8 & 4,4 & 207,0 & 10,0 & 230,0 & 110,0 \\
\hline Zircon-018 & 510 & 320 & 0,63 & 0,0547 & 0,0031 & 0,5190 & 0,0320 & 0,0696 & 0,0011 & 0,10 & 0,0216 & 0,0011 & 435,0 & 6,7 & 423,0 & 22,0 & 380,0 & 140,0 \\
\hline
\end{tabular}


Anexo 1.8. Resultados isotópicos U-Pb en circón de la muestra LMC-071

\begin{tabular}{|c|c|c|c|c|c|c|c|c|c|c|c|c|c|c|c|c|}
\hline Punto & $\mathrm{U}(\mathrm{ppm})$ & Th (ppm) & $\mathrm{Th} / \mathrm{U}$ & ${ }^{207 \mathrm{~Pb} / 206 \mathrm{~Pb}}$ & $\pm 2 \sigma$ & ${ }^{207} \mathrm{~Pb} / 235 \mathrm{U}$ & $\pm 2 \sigma$ & ${ }^{206} \mathrm{~Pb} /{ }^{238} \mathrm{U}$ & $\pm 2 \sigma$ & $\begin{array}{c}\text { Correlación } \\
\text { de errores }\end{array}$ & $\begin{array}{c}\begin{array}{c}\text { Edad }{ }^{206} \mathrm{~Pb} /{ }^{238} \mathrm{U} \\
(\mathrm{Ma})\end{array} \\
\end{array}$ & $\pm 2 \sigma$ & $\begin{array}{c}\begin{array}{c}\mathrm{Edad}^{207} \mathrm{~Pb} /{ }^{235} \mathrm{U} \\
(\mathrm{Ma})\end{array} \\
\end{array}$ & $\pm 2 \sigma$ & $\begin{array}{c}\text { Edad } \\
{ }^{207} \mathrm{~Pb} / 206 \mathrm{~Pb}(\mathrm{Ma})\end{array}$ & $\pm 2 \sigma$ \\
\hline LMC-071-68 & $12.000,00$ & $5.960,00$ & 0,50 & 0,36430 & 0,00690 & 0,5470 & 0,0120 & 0,01101 & 0,00038 & 0,7460 & 42,43 & 3,49 & 440,30 & 7,30 & 3754,00 & 31,00 \\
\hline LMC-071-73 & $20.920,00$ & $12.080,00$ & 0,58 & 0,31400 & 0,00520 & 0,5510 & 0,0120 & 0,01265 & 0,00021 & 0,6128 & 53,90 & 3,49 & 444,60 & 7,50 & 3540,00 & 26,00 \\
\hline LMC-071-47 & $14.710,00$ & $7.410,00$ & 0,50 & 0,24980 & 0,00320 & 0,4635 & 0,0063 & 0,01366 & 0,00020 & 0,3128 & 65,27 & 3,43 & 386,40 & 4,40 & 3182,00 & 22,00 \\
\hline LMC-071-71 & $12.040,00$ & $6.430,00$ & 0,53 & 0,28230 & 0,00510 & 0,5290 & 0,0098 & 0,01371 & 0,00017 & 0,1000 & 61,92 & 3,55 & 431,30 & 6,80 & 3354,00 & 36,00 \\
\hline LMC-071-49 & $13.650,00$ & $5.421,00$ & 0,40 & 0,19610 & 0,00750 & 0,3750 & 0,0130 & 0,01393 & 0,00011 & 0,1000 & 72,58 & 3,33 & 321,90 & 9,60 & 2737,00 & 66,00 \\
\hline LMC-071-11 & $9.100,00$ & $4.470,00$ & 0,49 & 0,23760 & 0,00740 & 0,4650 & 0,0120 & 0,01456 & 0,00017 & 0,1000 & 70,99 & 3,60 & 387,70 & 8,70 & 3085,00 & 53,00 \\
\hline LMC-071-41 & $10.270,00$ & $4.040,00$ & 0,39 & 0,19210 & 0,00640 & 0,3870 & 0,0120 & 0,01474 & 0,00022 & 0,1000 & 77,26 & 3,60 & 332,00 & 8,40 & 2742,00 & 58,00 \\
\hline LMC-071-24 & $12.010,00$ & $5.980,00$ & 0,50 & 0,25050 & 0,00520 & 0,5086 & 0,0093 & 0,01514 & 0,00010 & 0,1000 & 72,27 & 3,75 & 417,00 & 6,30 & 3169,00 & 33,00 \\
\hline LMC-071-48 & $14.000,00$ & $5.850,00$ & 0,42 & 0,21180 & 0,00320 & 0,4376 & 0,0060 & 0,01518 & 0,00019 & 0,1000 & 77,16 & 3,63 & 368,80 & 4,30 & $2.913,00$ & 26,00 \\
\hline LMC-071-28 & $7.730,00$ & $2.990,00$ & 0,39 & 0,24100 & 0,00760 & 0,4960 & 0,0180 & 0,01519 & 0,00019 & 0,0898 & 73,65 & 3,85 & 407,00 & 12,00 & $3.115,00$ & 53,00 \\
\hline LMC-071-26 & $10.610,00$ & $4.490,00$ & 0,42 & 0,17970 & 0,00470 & 0,3610 & 0,0100 & 0,01523 & 0,00014 & 0,1000 & 81,34 & 3,57 & 314,20 & 7,50 & $2.615,00$ & 49,00 \\
\hline LMC-071-50 & $9.280,00$ & $3.380,00$ & 0,36 & 0,12600 & 0,00310 & 0,2705 & 0,0077 & 0,01555 & 0,00016 & 0,4862 & 89,75 & 3,60 & 242,20 & 6,10 & $2.027,00$ & 41,00 \\
\hline LMC-071-66 & $6.800,00$ & $2.970,00$ & 0,44 & 0,23000 & 0,00830 & 0,4910 & 0,0150 & 0,01569 & 0,00018 & 0,1000 & 77,45 & 3,93 & 404,00 & 11,00 & $3.004,00$ & 67,00 \\
\hline LMC-071-10 & $13.640,00$ & $6.010,00$ & 0,44 & 0,23330 & 0,00420 & 0,5056 & 0,0085 & 0,01575 & 0,00024 & 0,2359 & 77,33 & 3,92 & 415,50 & 5,70 & $3.074,00$ & 30,00 \\
\hline LMC-071-61 & $11.900,00$ & $5.830,00$ & 0,49 & 0,16310 & 0,00960 & 0,3470 & 0,0130 & 0,01574 & 0,00044 & 0,1000 & 86,15 & 4,43 & 302,00 & 10,00 & $2.420,00$ & 100,00 \\
\hline LMC-071-72 & $10.120,00$ & $4.760,00$ & 0,47 & 0,26160 & 0,00640 & 0,5640 & 0,0120 & 0,01576 & 0,00024 & 0,1000 & 73,80 & 4,08 & 453,40 & 7,90 & $3.230,00$ & 49,00 \\
\hline LMC-071-3 & $3.360,00$ & $1.520,00$ & 0,45 & 0,31650 & 0,00650 & 0,6990 & 0,0140 & 0,01608 & 0,00021 & 0,1895 & 68,20 & 4,35 & 538,20 & 8,20 & $3.558,00$ & 33,00 \\
\hline LMC-071-38 & $6.750,00$ & $3.190,00$ & 0,47 & 0,13870 & 0,00630 & 0,3150 & 0,0140 & 0,01657 & 0,00022 & 0,0445 & 93,92 & 3,95 & 277,00 & 11,00 & $2.172,00$ & 84,00 \\
\hline LMC-071-70 & $8.300,00$ & $3.660,00$ & 0,44 & 0,14080 & 0,00480 & 0,3270 & 0,0120 & 0,01682 & 0,00016 & 0,3058 & 95,05 & 3,90 & 287,90 & 8,90 & $2.215,00$ & 64,00 \\
\hline LMC-071-63 & $9.420,00$ & $4.020,00$ & 0,43 & 0,11160 & 0,00230 & 0,2608 & 0,0045 & 0,01695 & 0,00024 & 0,1234 & 99,75 & 4,02 & 235,10 & 3,60 & $1.832,00$ & 36,00 \\
\hline LMC-071-35 & $8.130,00$ & $3.820,00$ & 0,47 & 0,13040 & 0,00670 & 0,3060 & 0,0110 & 0,01717 & 0,00043 & 0,1000 & 98,45 & 4,64 & 269,50 & 8,30 & $2.007,00$ & 92,00 \\
\hline LMC-071-39 & $8.440,00$ & $3.660,00$ & 0,43 & 0,13220 & 0,00270 & 0,3164 & 0,0052 & 0,01740 & 0,00013 & 0,1000 & 99,51 & 3,90 & 278,80 & 4,00 & $2.134,00$ & 36,00 \\
\hline LMC-071-34 & $9.650,00$ & $4.570,00$ & 0,47 & 0,15440 & 0,00960 & 0,3560 & 0,0160 & 0,01791 & 0,00038 & 0,1000 & 99,24 & 4,68 & 305,00 & 12,00 & $2.170,00$ & 120,00 \\
\hline LMC-071-29 & $9.350,00$ & $3.720,00$ & 0,40 & 0,09130 & 0,00400 & 0,2250 & 0,0110 & 0,01800 & 0,00017 & 0,3146 & 108,82 & 4,16 & 205,10 & 8,80 & $1.395,00$ & 85,00 \\
\hline LMC-071-40 & $8.750,00$ & $3.900,00$ & 0,45 & 0,12410 & 0,00850 & 0,2980 & 0,0150 & 0,01829 & 0,00045 & 0,1000 & 105,77 & 4,93 & 262,00 & 12,00 & $1.750,00$ & 130,00 \\
\hline LMC-071-5 & $7.830,00$ & $3.300,00$ & 0,42 & 0,14470 & 0,00450 & 0,3592 & 0,0086 & 0,01835 & 0,00020 & 0,1000 & 103,09 & 4,25 & 310,60 & 6,50 & $2.261,00$ & 56,00 \\
\hline LMC-071-4 & $7.890,00$ & $3.380,00$ & 0,43 & 0,16720 & 0,00420 & 0,4215 & 0,0074 & 0,01841 & 0,00039 & 0,1826 & 100,11 & 4,67 & 356,90 & 5,30 & $2.523,00$ & 42,00 \\
\hline LMC-071-19 & $7.730,00$ & $2.710,00$ & 0,35 & 0,07500 & 0,00140 & 0,1861 & 0,0036 & 0,01848 & 0,00038 & 0,6148 & 114,11 & 4,76 & 173,00 & 3,10 & $1.051,00$ & 39,00 \\
\hline LMC-071-69 & $8.470,00$ & $4.390,00$ & 0,52 & 0,09880 & 0,00380 & 0,2524 & 0,0067 & 0,01854 & 0,00025 & 0,1000 & 110,96 & 4,44 & 228,30 & 5,50 & $1.573,00$ & 72,00 \\
\hline LMC- $071-43$ & $7.350,00$ & $3.030,00$ & 0,41 & 0,08160 & 0,00240 & 0,2194 & 0,0049 & 0,01876 & 0,00036 & 0,2020 & 114,84 & 4,75 & 202,00 & 4,00 & $1.233,00$ & 59,00 \\
\hline LMC-071-8 & $6.390,00$ & $2.520,00$ & 0,39 & 0,09960 & 0,00160 & 0,2583 & 0,0048 & 0,01936 & 0,00024 & 0,3043 & 115,71 & 4,53 & 232,90 & 3,90 & $1.604,00$ & 31,00 \\
\hline LMC-071-45 & $6.190,00$ & $1.700,00$ & 0,27 & 0,06730 & 0,00170 & 0,1828 & 0,0042 & 0,01969 & 0,00019 & 0,1513 & 122,75 & 4,62 & 170,20 & 3,60 & 844,00 & 51,00 \\
\hline LMC-071-44 & $7.010,00$ & 2340,00 & 0,33 & 0,06660 & 0,00180 & 0,1839 & 0,0078 & 0,01978 & 0,00056 & 0,6439 & 123,42 & 5,66 & 168,10 & 5,60 & 783,00 & 49,00 \\
\hline LMC-071-33 & $7.760,00$ & $3.030,00$ & 0,39 & 0,09860 & 0,00630 & 0,2700 & 0,0150 & 0,01991 & 0,00054 & 0,0373 & 119,14 & 5,53 & 241,00 & 12,00 & $1.490,00$ & 120,00 \\
\hline LMC-071-53 & $7.690,00$ & $3.410,00$ & 0,44 & 0,12200 & 0,01200 & 0,3080 & 0,0220 & 0,02019 & 0,00060 & 0,1000 & 117,04 & 5,95 & 267,00 & 16,00 & $1.590,00$ & 180,00 \\
\hline LMC-071-14 & $11.450,00$ & $4.800,00$ & 0,42 & 0,13150 & 0,00580 & 0,3598 & 0,0081 & 0,02028 & 0,00092 & 0,3426 & 116,02 & 7,10 & 312,60 & 5,90 & $2.093,00$ & 83,00 \\
\hline LMC-071-21 & $7.580,00$ & $2.693,00$ & 0,36 & 0,06560 & 0,00098 & 0,1795 & 0,0028 & 0,02028 & 0,00026 & 0,5487 & 126,68 & 4,86 & 167,70 & 2,50 & 793,00 & 31,00 \\
\hline LMC-071-25 & $7.850,00$ & $2.530,00$ & 0,32 & 0,06281 & 0,00085 & 0,1748 & 0,0030 & 0,02047 & 0,00021 & 0,5482 & 128,31 & 4,81 & 163,50 & 2,60 & 699,00 & 29,00 \\
\hline LMC-071-42 & $5.680,00$ & $1.930,00$ & 0,34 & 0,06170 & 0,00130 & 0,1765 & 0,0045 & 0,02090 & 0,00034 & 0,6325 & 131,18 & 5,19 & 164,20 & 3,70 & 633,00 & 41,00 \\
\hline LMC-071-20 & $8.770,00$ & $3.690,00$ & 0,42 & 0,07290 & 0,00290 & 0,2091 & 0,0067 & 0,02116 & 0,00026 & 0,1000 & 130,91 & 5,05 & 192,60 & 5,60 & 970,00 & 80,00 \\
\hline LMC-071-55 & $5.700,00$ & $2.320,00$ & 0,41 & 0,07400 & 0,00160 & 0,2185 & 0,0039 & 0,02148 & 0,00033 & 0,1889 & 132,69 & 5,21 & 200,40 & 3,30 & $1.036,00$ & 45,00 \\
\hline LMC-071-7 & $6.800,00$ & $2.560,00$ & 0,38 & 0,08520 & 0,00270 & 0,2497 & 0,0073 & 0,02154 & 0,00023 & 0,1000 & 131,14 & 5,01 & 225,40 & 5,90 & $1.284,00$ & 64,00 \\
\hline LMC-071-16 & $7.190,00$ & $2.980,00$ & 0,41 & 0,12800 & 0,01000 & 0,3460 & 0,0160 & 0,02157 & 0,00080 & 0,1000 & 123,96 & 6,79 & 299,00 & 12,00 & $1.840,00$ & 130,00 \\
\hline LMC-071-2 & $6.620,00$ & $3.080,00$ & 0,47 & 0,08410 & 0,00310 & 0,2474 & 0,0073 & 0,02170 & 0,00031 & 0,1000 & 132,29 & 5,20 & 224,00 & 5,90 & $1.246,00$ & 72,00 \\
\hline LMC-071-60 & $8.890,00$ & $3.220,00$ & 0,36 & 0,08180 & 0,00330 & 0,2353 & 0,0045 & 0,02188 & 0,00086 & 0,1000 & 133,79 & 7,41 & 214,70 & 3,70 & $1.215,00$ & 83,00 \\
\hline LMC-071-37 & $5.010,00$ & $2.061,00$ & 0,41 & 0,05990 & 0,00150 & 0,1833 & 0,0066 & 0,02232 & 0,00064 & 0,5819 & 140,35 & 6,31 & 170,40 & 5,60 & 583,00 & 55,00 \\
\hline LMC-071-56 & $6.620,00$ & $2.010,00$ & 0,30 & 0,06020 & 0,00120 & 0,1828 & 0,0066 & 0,02248 & 0,00071 & 0,6294 & 141,29 & 6,93 & 168,90 & 5,40 & 594,00 & 42,00 \\
\hline LMC-071-57 & $9.400,00$ & $3.740,00$ & 0,40 & 0,10210 & 0,00870 & 0,2950 & 0,0150 & 0,02250 & 0,00110 & 0,1000 & 133,92 & 7,98 & 262,00 & 11,00 & $1.470,00$ & 150,00 \\
\hline LMC-071-51 & $6.430,00$ & $2.710,00$ & 0,42 & 0,06600 & 0,00110 & 0,2021 & 0,0041 & 0,02264 & 0,00055 & 0,6918 & 141,25 & 6,09 & 186,60 & 3,40 & 793,00 & 36,00 \\
\hline LMC-071-54 & $6.810,00$ & $2.400,00$ & 0,35 & 0,09210 & 0,00770 & 0,2590 & 0,0120 & 0,02266 & 0,00093 & 0,1000 & 136,67 & 7,46 & 233,50 & 9,30 & $1.270,00$ & 150,00 \\
\hline LMC-071-23 & $8.390,00$ & $3.670,00$ & 0,44 & 0,12300 & 0,00520 & 0,3430 & 0,0130 & 0,02267 & 0,00068 & 0,2297 & 131,15 & 6,68 & 300,00 & 10,00 & $1.952,00$ & 83,00 \\
\hline LMC-071-12 & $9.830,00$ & $3.510,00$ & 0,36 & 0,05831 & 0,00099 & 0,1773 & 0,0039 & 0,02268 & 0,00037 & 0,7927 & 142,88 & 5,64 & 165,60 & 3,30 & 530,00 & 37,00 \\
\hline LMC-071-46 & $7.620,00$ & $3.260,00$ & 0,43 & 0,09610 & 0,00560 & 0,2770 & 0,0100 & 0,02268 & 0,00068 & 0,1000 & 136,07 & 6,79 & 246,70 & 7,90 & $1.350,00$ & 110,00 \\
\hline LMC-071-18 & $7.400,00$ & $2.920,00$ & 0,39 & 0,07340 & 0,00210 & 0,2261 & 0,0061 & 0,02280 & 0,00025 & 0,0078 & 140,90 & 5,35 & 206,80 & 5,00 & 995,00 & 60,00 \\
\hline 64 & $8.660,00$ & $3.400,00$ & 39 & 0,06430 & 130 & 0,2089 & 0,0038 & 0,02341 & 0,00036 & 0,3091 & 146,33 & 5,74 & 192,50 & 3,20 & 766,00 & 43,00 \\
\hline
\end{tabular}




\begin{tabular}{|c|c|c|c|c|c|c|c|c|c|c|c|c|c|c|c|c|}
\hline Punto & $\mathrm{U}(\mathrm{ppm})$ & Th (ppm) & $\mathrm{Th} / \mathrm{U}$ & ${ }^{207} \mathrm{~Pb} /{ }^{206} \mathrm{~Pb}$ & $\pm 2 \sigma$ & ${ }^{207} \mathrm{~Pb} /{ }^{235} \mathrm{U}$ & $\pm 2 \sigma$ & ${ }^{206} \mathrm{~Pb} /{ }^{338} \mathrm{U}$ & $\pm 2 \sigma$ & $\begin{array}{l}\text { Correlación } \\
\text { de errores }\end{array}$ & $\begin{array}{c}\text { Edad }{ }^{206} \mathrm{~Pb} / 238 \mathrm{U} \\
(\mathrm{Ma})\end{array}$ & $\pm 2 \sigma$ & $\begin{array}{c}\text { Edad }{ }^{207} \mathrm{~Pb} / 235 \mathrm{U} \\
(\mathrm{Ma})\end{array}$ & $\pm 2 \sigma$ & $\begin{array}{c}\text { Edad } \\
{ }^{207} \mathrm{~Pb} /{ }^{206} \mathrm{~Pb} \text { (Ma) }\end{array}$ & $\pm 2 \sigma$ \\
\hline LMC-071-62 & $8.540,00$ & $2.690,00$ & 0,31 & 0,06510 & 0,00350 & 0,2065 & 0,0058 & 0,02343 & 0,00094 & 0,0569 & 146,31 & 8,15 & 190,30 & 4,80 & 720,00 & 110,00 \\
\hline LMC-071-58 & $7.070,00$ & $3.050,00$ & 0,43 & 0,15400 & 0,01200 & 0,5320 & 0,0670 & 0,02407 & 0,00097 & 0,9646 & 133,27 & 7,94 & 417,00 & 39,00 & $2.350,00$ & 120,00 \\
\hline LMC-071-22 & $6.560,00$ & $2.590,00$ & 0,39 & 0,05485 & 0,00072 & 0,1864 & 0,0028 & 0,02477 & 0,00031 & 0,5604 & 156,62 & 5,90 & 173,40 & 2,40 & 405,00 & 30,00 \\
\hline LMC-071-15 & $5.660,00$ & $2.120,00$ & 0,37 & 0,06040 & 0,00140 & 0,2027 & 0,0042 & 0,02492 & 0,00044 & 0,6139 & 156,47 & 6,25 & 186,70 & 3,40 & 607,00 & 50,00 \\
\hline LMC-071-32 & $5.650,00$ & $1.960,00$ & 0,35 & 0,06820 & 0,00300 & 0,2290 & 0,0060 & 0,02537 & 0,00042 & 0,1000 & 157,70 & 6,24 & 208,80 & 4,90 & 839,00 & 87,00 \\
\hline LMC-071-67 & $2.780,00$ & $1.000,00$ & 0,36 & 0,07230 & 0,00230 & 0,2518 & 0,0084 & 0,02560 & 0,00033 & 0,2068 & 158,29 & 6,09 & 227,70 & 6,30 & 959,00 & 61,00 \\
\hline LMC-071-65 & $5.570,00$ & $1.783,00$ & 0,32 & 0,05896 & 0,00087 & 0,2174 & 0,0037 & 0,02680 & 0,00021 & 0,5102 & 168,48 & 6,20 & 199,80 & 3,10 & 555,00 & 32,00 \\
\hline LMC-071-59 & $6.600,00$ & $1.990,00$ & 0,30 & 0,05460 & 0,00075 & 0,2026 & 0,0034 & 0,02709 & 0,00029 & 0,5530 & 171,22 & 6,34 & 187,10 & 2,80 & 385,00 & 29,00 \\
\hline LMC-071-17 & $6.270,00$ & $2.210,00$ & 0,35 & 0,05790 & 0,00110 & 0,2137 & 0,0035 & 0,02749 & 0,00022 & 0,1000 & 173,01 & 6,33 & 196,70 & 2,90 & 506,00 & 41,00 \\
\hline LMC-071-30 & $4.150,00$ & 1910,00 & 0,46 & 0,06650 & 0,00170 & 0,2495 & 0,0068 & 0,02786 & 0,00037 & 0,3667 & 173,42 & 6,91 & 225,40 & 5,50 & 804,00 & 51,00 \\
\hline LMC-071-36 & $2.650,00$ & 864,00 & 0,33 & 0,05600 & 0,00180 & 0,2253 & 0,0074 & 0,02956 & 0,00033 & 0,1260 & 186,36 & 6,97 & 205,90 & 6,10 & 435,00 & 69,00 \\
\hline LMC-071-52 & 375,00 & 345,00 & 0,92 & 0,05960 & 0,00310 & 0,2420 & 0,0120 & 0,02966 & 0,00037 & 0,1000 & 186,14 & 6,97 & 221,20 & 9,50 & 530,00 & 110,00 \\
\hline LMC-071-13 & $4.190,00$ & $1.720,00$ & 0,41 & 0,05331 & 0,00096 & 0,2288 & 0,0049 & 0,03149 & 0,00034 & 0,4824 & 199,07 & 7,60 & 209,30 & 4,00 & 329,00 & 40,00 \\
\hline LMC-071-6 & 461,00 & 402,00 & 0,87 & 0,05880 & 0,00170 & 0,6260 & 0,0190 & 0,07853 & 0,00062 & 0,1494 & 486,22 & 17,82 & 493,00 & 11,00 & 531,00 & 59,00 \\
\hline LMC-071-1 & 246,00 & 210,00 & 0,85 & 0,05610 & 0,00260 & 0,6500 & 0,0300 & 0,08420 & 0,00120 & 0,2440 & 522,19 & 19,67 & 505,00 & 18,00 & 432,00 & 88,00 \\
\hline LMC-071-31 & $1.467,00$ & 211,00 & 0,14 & 0,06650 & 0,00110 & 0,7660 & 0,0350 & 0,08440 & 0,00290 & 0,9366 & 516,88 & 25,37 & 573,00 & 20,00 & 814,00 & 35,00 \\
\hline LMC-071-9 & 0,02 & 0,02 & 0,83 & & & & & & & & & & & & & \\
\hline
\end{tabular}

Campos en blanco: no se obtuvieron resultados de los análisis en el laboratorio 
Anexo 1.9. Resultados isotópicos U-Pb en circón de la muestra TCR-380

\begin{tabular}{|c|c|c|c|c|c|c|c|c|c|c|c|c|c|c|c|c|}
\hline Punto & $\mathrm{U}(\mathrm{ppm})$ & $\begin{array}{c}\begin{array}{c}\text { Th } \\
(\mathrm{ppm})\end{array} \\
\text { (p) }\end{array}$ & $\mathrm{Th} / \mathrm{U}$ & ${ }^{207 \mathrm{~Pb} / 2006 \mathrm{~Pb}}$ & $\pm 2 \sigma$ & ${ }^{207} \mathrm{~Pb} / 235 \mathrm{U}$ & $\pm 2 \sigma$ & ${ }^{206} \mathrm{~Pb} / 238 \mathrm{U}$ & $\pm 2 \sigma$ & $\begin{array}{c}\text { Correlación } \\
\text { de errores }\end{array}$ & $\begin{array}{c}\begin{array}{c}E d a d{ }^{206} \mathrm{~Pb} / 238 \mathrm{U} \\
(\mathrm{Ma})\end{array} \\
\end{array}$ & $\pm 2 \sigma$ & 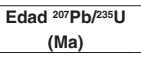 & $\pm 2 \sigma$ & $\begin{array}{c}\text { Edad } \\
{ }_{207} \mathrm{~Pb} / 206 \mathrm{~Pb}(\mathrm{Ma})\end{array}$ & $\pm 2 \sigma$ \\
\hline TCR-380-42 & 865,00 & 700,00 & 0,81 & 0,05840 & 0,00310 & 0,0884 & 0,0049 & 0,01105 & 0,00018 & 0,3362 & 69,87 & 2,40 & 86,00 & 4,50 & 500,00 & 100,00 \\
\hline TCR-380-40 & 293,00 & 112,30 & 0,38 & 0,05290 & 0,00510 & 0,0864 & 0,0081 & 0,01166 & 0,00025 & 0,0553 & 74,22 & 2,80 & 82,90 & 7,60 & 220,00 & 170,00 \\
\hline TCR-380-49 & 327,00 & 99,90 & 0,31 & 0,04610 & 0,00440 & 0,0764 & 0,0073 & 0,01168 & 0,00021 & 0,1292 & 74,99 & 2,66 & 74,30 & 7,00 & 30,00 & 160,00 \\
\hline TCR-380-38 & 913,00 & 398,00 & 0,44 & 0,05190 & 0,00290 & 0,0867 & 0,0052 & 0,01224 & 0,00026 & 0,2887 & 78,00 & 2,90 & 84,40 & 4,90 & 240,00 & 110,00 \\
\hline TCR-380-18 & $1.611,00$ & $2.406,00$ & 1,49 & 0,05230 & 0,00130 & 0,2064 & 0,0054 & 0,02823 & 0,00024 & 0,2590 & 178,87 & 5,59 & 190,50 & 4,50 & 277,00 & 51,00 \\
\hline TCR-380-28 & $1.093,00$ & 639,00 & 0,58 & 0,05020 & 0,00130 & 0,2045 & 0,0061 & 0,02900 & 0,00047 & 0,5420 & 184,19 & 6,26 & 188,80 & 5,20 & 202,00 & 53,00 \\
\hline TCR-380-43 & 394,00 & 473,00 & 1,20 & 0,04950 & 0,00250 & 0,2020 & 0,0100 & 0,02931 & 0,00034 & 0,2224 & 186,30 & 5,98 & 187,50 & 8,80 & 192,00 & 94,00 \\
\hline TCR-380-4 & 824,00 & 854,00 & 1,04 & 0,05080 & 0,00270 & 0,2080 & 0,0110 & 0,02954 & 0,00037 & 0,2228 & 187,45 & 6,11 & 191,90 & 9,10 & 230,00 & 100,00 \\
\hline TCR-380-13 & $1.628,00$ & 11,40 & 0,01 & 0,04880 & 0,00150 & 0,2007 & 0,0066 & 0,02967 & 0,00026 & 0,2208 & 188,73 & 5,85 & 185,50 & 5,50 & 155,00 & 63,00 \\
\hline TCR-380-50 & 384,00 & 460,80 & 1,20 & 0,05070 & 0,00230 & 0,2123 & 0,0097 & 0,02969 & 0,00038 & 0,2172 & 188,41 & 6,17 & 194,60 & 8,00 & 221,00 & 88,00 \\
\hline TCR-380-14 & 349,00 & 382,00 & 1,09 & 0,05310 & 0,00400 & 0,2200 & 0,0140 & 0,02992 & 0,00060 & 0,0415 & 189,29 & 7,18 & 204,00 & 12,00 & 340,00 & 120,00 \\
\hline TCR-380-25 & 120,10 & 167,40 & 1,39 & 0,04830 & 0,00360 & 0,2030 & 0,0150 & 0,02996 & 0,00053 & 0,0687 & 190,68 & 6,56 & 185,00 & 12,00 & 110,00 & 130,00 \\
\hline TCR-380-39 & 330,00 & 306,00 & 0,93 & 0,04970 & 0,00250 & 0,2064 & 0,0099 & 0,03001 & 0,00043 & 0,1100 & 190,66 & 6,30 & 191,90 & 8,40 & 197,00 & 92,00 \\
\hline TCR-380-24 & $1.173,00$ & $3.450,00$ & 2,94 & 0,05000 & 0,00110 & 0,2124 & 0,0048 & 0,03002 & 0,00024 & 0,1634 & 190,65 & 5,91 & 195,30 & 4,00 & 195,00 & 48,00 \\
\hline TCR-380-29 & 222,00 & 366,00 & 1,65 & 0,05870 & 0,00450 & 0,2440 & 0,0190 & 0,03018 & 0,00051 & 0,2593 & 189,59 & 6,62 & 219,00 & 16,00 & 490,00 & 150,00 \\
\hline TCR-380-44 & $1.320,00$ & $2.170,00$ & 1,64 & 0,08230 & 0,00470 & 0,3390 & 0,0180 & 0,03045 & 0,00050 & 0,4230 & 185,61 & 6,80 & 294,00 & 13,00 & $1.159,00$ & 96,00 \\
\hline TCR-380-8 & 847,00 & $1.510,00$ & 1,78 & 0,05380 & 0,00250 & 0,2314 & 0,0098 & 0,03071 & 0,00056 & 0,2353 & 194,07 & 6,55 & 210,30 & 8,00 & 374,00 & 96,00 \\
\hline TCR-380-7 & $1.557,00$ & $1.358,00$ & 0,87 & 0,06330 & 0,00340 & 0,2750 & 0,0160 & 0,03093 & 0,00024 & 0,3889 & 193,13 & 6,15 & 242,00 & 12,00 & 600,00 & 100,00 \\
\hline TCR-380-16 & 405,00 & 505,00 & 1,25 & 0,05410 & 0,00290 & 0,2360 & 0,0130 & 0,03114 & 0,00059 & 0,2167 & 196,69 & 7,17 & 213,00 & 11,00 & 380,00 & 100,00 \\
\hline TCR-380-20 & 545,00 & 426,00 & 0,78 & 0,09250 & 0,00580 & 0,4060 & 0,0300 & 0,03116 & 0,00065 & 0,6467 & 187,39 & 7,40 & 341,00 & 22,00 & $1.380,00$ & 130,00 \\
\hline TCR-380-37 & $1.224,00$ & 897,00 & 0,73 & 0,05140 & 0,00150 & 0,2228 & 0,0066 & 0,03154 & 0,00034 & 0,1753 & 199,86 & 6,36 & 203,50 & 5,50 & 264,00 & 62,00 \\
\hline TCR-380-60 & $3.860,00$ & $4.820,00$ & 1,25 & 0,05190 & 0,00210 & 0,2076 & 0,0081 & 0,03160 & 0,00100 & 0,5588 & 200,11 & 8,98 & 191,10 & 6,80 & 285,00 & 81,00 \\
\hline TCR-380-36 & 216,00 & 297,00 & 1,38 & 0,05180 & 0,00310 & 0,2280 & 0,0140 & 0,03169 & 0,00056 & 0,0592 & 200,70 & 7,18 & 209,00 & 11,00 & 260,00 & 110,00 \\
\hline TCR-380-54 & 506,00 & 577,00 & 1,14 & 0,04940 & 0,00200 & 0,2152 & 0,0088 & 0,03187 & 0,00043 & 0,1250 & 202,43 & 6,55 & 197,30 & 7,20 & 166,00 & 78,00 \\
\hline TCR-380-27 & 381,00 & 388,00 & 1,02 & 0,05920 & 0,00230 & 0,2730 & 0,0110 & 0,03276 & 0,00049 & 0,4218 & 205,50 & 7,19 & 244,60 & 8,90 & 550,00 & 82,00 \\
\hline TCR-380-32 & 854,00 & 824,00 & 0,96 & 0,06330 & 0,00210 & 0,2965 & 0,0087 & 0,03340 & 0,00033 & 0,1000 & 208,40 & 6,63 & 262,80 & 6,80 & 722,00 & 67,00 \\
\hline TCR-380-9 & $2.245,00$ & 135,00 & 0,06 & 0,05030 & 0,00110 & 0,2366 & 0,0066 & 0,03386 & 0,00060 & 0,6044 & 214,69 & 7,16 & 215,00 & 5,40 & 202,00 & 47,00 \\
\hline TCR-380-51 & 441,00 & 12,20 & 0,03 & 0,05550 & 0,00260 & 0,2720 & 0,0150 & 0,03430 & 0,00086 & 0,5403 & 216,06 & 8,40 & 242,00 & 12,00 & 436,00 & 98,00 \\
\hline TCR-380-30 & 8,17 & 0,09 & 0,01 & 0,12900 & 0,03100 & 0,6000 & 0,1300 & 0,03730 & 0,00240 & 0,1025 & 213,28 & 18,08 & 347,00 & 78,00 & 200,00 & 470,00 \\
\hline TCR-380-23 & 486,00 & 10,29 & 0,02 & 0,05890 & 0,00190 & 0,3260 & 0,0160 & 0,03810 & 0,00130 & 0,7006 & 238,70 & 10,83 & 285,00 & 12,00 & 554,00 & 69,00 \\
\hline TCR-380-45 & 486,00 & 535,00 & 1,10 & 0,05160 & 0,00190 & 0,3110 & 0,0110 & 0,04233 & 0,00050 & 0,1295 & 267,26 & 8,48 & 272,80 & 8,70 & 271,00 & 73,00 \\
\hline TCR-380-35 & 24,10 & 4,11 & 0,17 & 0,09200 & 0,01700 & 0,4370 & 0,0660 & 0,04390 & 0,00210 & 0,0180 & 263,27 & 16,59 & 320,00 & 46,00 & 400,00 & 310,00 \\
\hline TCR-380-12 & $2.320,00$ & 571,00 & 0,25 & 0,05474 & 0,00098 & 0,3629 & 0,0065 & 0,04825 & 0,00040 & 0,2957 & 302,90 & 9,13 & 314,70 & 4,80 & 393,00 & 39,00 \\
\hline TCR-380-34 & $1.471,00$ & 446,00 & 0,30 & 0,05390 & 0,00100 & 0,3750 & 0,0130 & 0,05010 & 0,00120 & 0,7886 & 314,67 & 12,12 & 321,90 & 9,50 & 362,00 & 42,00 \\
\hline TCR-380-52 & 311,50 & 107,00 & 0,34 & 0,05700 & 0,00200 & 0,4170 & 0,0140 & 0,05284 & 0,00065 & 0,2340 & 330,34 & 10,99 & 354,00 & 10,00 & 459,00 & 73,00 \\
\hline TCR-380-10 & $1.713,00$ & 209,90 & 0,12 & 0,05580 & 0,00110 & 0,4850 & 0,0140 & 0,06270 & 0,00140 & 0,7167 & 391,41 & 14,60 & 401,30 & 9,50 & 436,00 & 43,00 \\
\hline TCR-380-26 & $1.193,00$ & 646,00 & 0,54 & 0,05667 & 0,00086 & 0,5143 & 0,0088 & 0,06401 & 0,00054 & 0,4559 & 399,01 & 12,27 & 420,50 & 5,90 & 481,00 & 36,00 \\
\hline TCR-380-48 & 324,00 & 111,40 & 0,34 & 0,09420 & 0,00500 & 0,9300 & 0,0510 & 0,06930 & 0,00110 & 0,0623 & 411,68 & 15,28 & 663,00 & 27,00 & $1.520,00$ & 100,00 \\
\hline TCR-380-2 & $1.016,00$ & 385,10 & 0,38 & 0,05660 & 0,00140 & 0,5440 & 0,0140 & 0,06948 & 0,00076 & 0,2711 & 432,45 & 13,51 & 440,90 & 8,70 & 464,00 & 55,00 \\
\hline TCR-380-17 & 596,00 & 476,00 & 0,80 & 0,06240 & 0,00220 & 0,6100 & 0,0230 & 0,07094 & 0,00096 & 0,2555 & 438,25 & 14,74 & 484,00 & 14,00 & 674,00 & 79,00 \\
\hline TCR-380-46 & 265,00 & 246,60 & 0,93 & 0,06080 & 0,00200 & 0,6040 & 0,0200 & 0,07139 & 0,00081 & 0,2707 & 441,84 & 14,15 & 479,00 & 12,00 & 599,00 & 68,00 \\
\hline TCR-380-22 & 142,00 & 86,10 & 0,61 & 0,05790 & 0,00310 & 0,5840 & 0,0290 & 0,07220 & 0,00120 & 0,0867 & 448,32 & 15,36 & 465,00 & 19,00 & 480,00 & 110,00 \\
\hline TCR-380-55 & 467,00 & 24,50 & 0,05 & 0,06420 & 0,00180 & 0,7070 & 0,0230 & 0,07960 & 0,00120 & 0,3893 & 489,49 & 16,58 & 544,00 & 14,00 & 731,00 & 59,00 \\
\hline TCR-380-33 & $1.196,00$ & 245,00 & 0,20 & 0,06800 & 0,00130 & 0,8430 & 0,0180 & 0,08950 & 0,00100 & 0,4210 & 546,37 & 17,87 & 621,00 & 10,00 & 880,00 & 38,00 \\
\hline TCR-380-41 & 230,00 & 42,70 & 0,19 & 0,06940 & 0,00170 & 1,3650 & 0,0350 & 0,14150 & 0,00140 & 0,2656 & 851,25 & 26,92 & 872,00 & 15,00 & 902,00 & 55,00 \\
\hline TCR-380-53 & 276,00 & 19,00 & 0,07 & 0,07250 & 0,00170 & 1,4880 & 0,0380 & 0,14860 & 0,00180 & 0,1380 & 889,28 & 28,55 & 924,00 & 15,00 & 990,00 & 46,00 \\
\hline TCR-380-56 & 202,80 & 93,80 & 0,46 & 0,07830 & 0,00360 & 1,6320 & 0,0670 & 0,15240 & 0,00230 & 0,1805 & 905,09 & 31,38 & 981,00 & 27,00 & $1.135,00$ & 89,00 \\
\hline TCR-380-57 & 357,90 & 174,30 & 0,49 & 0,07520 & 0,00150 & 1,5960 & 0,0310 & 0,15510 & 0,00160 & 0,3588 & 923,93 & 30,05 & 968,00 & 12,00 & $1.081,00$ & 38,00 \\
\hline TCR-380-47 & 129,00 & 61,50 & 0,48 & 0,14140 & 0,00730 & 3,2400 & 0,1900 & 0,16070 & 0,00390 & 0,3860 & 882,40 & 39,96 & $1.456,00$ & 45,00 & $2.221,00$ & 93,00 \\
\hline TCR-380-21 & 138,00 & 45,40 & 0,33 & 0,08940 & 0,00310 & 2,3550 & 0,0740 & 0,18950 & 0,00400 & 0,3859 & $1.102,66$ & 41,08 & $1.235,00$ & 23,00 & $1.420,00$ & 64,00 \\
\hline TCR-380-19 & 438,00 & 36,10 & 0,08 & 0,09930 & 0,00150 & 3,0090 & 0,0470 & 0,21480 & 0,00220 & 0,4395 & $1.230,21$ & 41,51 & $1.408,00$ & 12,00 & $1.606,00$ & 27,00 \\
\hline TCR-380-31 & 309,60 & 174,60 & 0,56 & 0,16550 & 0,00230 & 5,6670 & 0,0950 & 0,24360 & 0,00240 & 0,5501 & $1.284,11$ & 53,52 & $1.925,00$ & 15,00 & $2.510,00$ & 23,00 \\
\hline TCR-380-1 & 0,08 & 0,00 & 0,00 & & & & & & & & & & & & & \\
\hline TCR-380-3 & 0,00 & 0,00 & $-151,24$ & & & & & & & & & & & & & \\
\hline TCR-380-5 & 0,01 & 0,00 & 0,23 & & & & & & & & & & & & & \\
\hline
\end{tabular}




\begin{tabular}{|c|c|c|c|c|c|c|c|c|c|c|c|c|c|c|c|c|}
\hline Punto & $\mathrm{U}(\mathrm{ppm})$ & $\begin{array}{c}\text { Th } \\
\text { (ppm) }\end{array}$ & $\mathrm{Th} / \mathrm{U}$ & ${ }^{207} \mathrm{~Pb} /{ }^{2065 \mathrm{~Pb}}$ & $\pm 2 \sigma$ & ${ }^{207} \mathrm{~Pb} /{ }^{235} \mathrm{U}$ & $\pm 2 \sigma$ & ${ }^{206} \mathrm{~Pb} /{ }^{238} \mathrm{U}$ & $\pm 2 \sigma$ & $\begin{array}{c}\text { Correlación } \\
\text { de errores }\end{array}$ & $\begin{array}{c}\text { Edad }{ }^{206} \mathrm{~Pb} /{ }^{238} \mathrm{U} \\
(\mathrm{Ma})\end{array}$ & $\pm 2 \sigma$ & 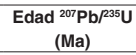 & $\pm 2 \sigma$ & $\begin{array}{c}\text { Edad } \\
{ }^{207} \mathrm{~Pb} /{ }^{206} \mathrm{~Pb} \text { (Ma) }\end{array}$ & $\pm 2 \sigma$ \\
\hline TCR-380-6 & 0,08 & 0,01 & 0,09 & & & & & & & & & & & & & \\
\hline TCR-380-11 & 0,00 & 0,01 & 2,72 & & & & & & & & & & & & & \\
\hline TCR-380-15 & 0,00 & 0,00 & $-0,19$ & & & & & & & & & & & & & \\
\hline TCR-380-58 & 0,03 & 0,19 & 7,46 & & & & & & & & & & & & & \\
\hline TCR-380-59 & 0,09 & 0,52 & 6,12 & & & & & & & & & & & & & \\
\hline
\end{tabular}

Campos en blanco: no se obtuvieron resultados de los análisis en el laboratorio 
Anexo 1.10. Resultados isotópicos U-Pb en circón de la muestra AMC-0136A

\begin{tabular}{|c|c|c|c|c|c|c|c|c|c|c|c|c|c|c|c|c|}
\hline Punto & $\mathrm{U}(\mathrm{ppm})$ & Th (ppm) & $\mathrm{Th} / \mathrm{U}$ & ${ }^{207} \mathrm{~Pb} /{ }^{206} \mathrm{~Pb}$ & $\pm 2 \sigma$ & ${ }^{207} \mathrm{~Pb} /{ }^{235} \mathrm{U}$ & $\pm 2 \sigma$ & ${ }^{206} \mathrm{~Pb} /{ }^{238} \mathrm{U}$ & $\pm 2 \sigma$ & $\begin{array}{c}\text { Correlación } \\
\text { de errores }\end{array}$ & $\begin{array}{c}\text { Edad }{ }^{206} \mathrm{~Pb} /{ }^{238} \mathrm{U} \\
(\mathrm{Ma})\end{array}$ & $\pm 2 \sigma$ & $\begin{array}{c}\text { Edad }{ }^{207} \mathrm{~Pb} / 235 \mathrm{U} \\
(\mathrm{Ma})\end{array}$ & $\pm 2 \sigma$ & $\begin{array}{c}\text { Edad } \\
{ }^{207} \mathrm{~Pb} /{ }^{206} \mathrm{~Pb}(\mathrm{Ma})\end{array}$ & $\pm 2 \sigma$ \\
\hline AMC-0136-A-11 & 149,00 & 134,00 & 0,90 & 0,05700 & 0,01100 & 0,1000 & 0,0190 & 0,01326 & 0,00053 & 0,1000 & 83,93 & 4,08 & 97,00 & 18,00 & 190,00 & 300,00 \\
\hline AMC-0136-A-21 & 71,80 & 20,59 & 0,29 & 0,05400 & 0,01000 & 0,1040 & 0,0190 & 0,01482 & 0,00054 & 0,0020 & 94,11 & 4,31 & 106,00 & 18,00 & 180,00 & 280,00 \\
\hline AMC-0136-A-7 & 428,00 & 165,00 & 0,39 & 0,05210 & 0,00400 & 0,1129 & 0,0086 & 0,01565 & 0,00047 & 0,2823 & 99,59 & 3,91 & 107,10 & 7,80 & 270,00 & 130,00 \\
\hline AMC-0136-A-19 & 45,10 & 13,19 & 0,29 & 0,03700 & 0,01300 & 0,0880 & 0,0280 & 0,01603 & 0,00067 & 0,0834 & 103,94 & 5,30 & 73,00 & 25,00 & $-470,00$ & 370,00 \\
\hline AMC-0136-A-24 & 235,00 & 239,00 & 1,02 & 0,04890 & 0,00350 & 0,1097 & 0,0078 & 0,01645 & 0,00032 & 0,0714 & 105,08 & 3,35 & 106,80 & 6,80 & 200,00 & 120,00 \\
\hline AMC-0136-A-17 & 71,10 & 18,10 & 0,25 & 0,05900 & 0,01300 & 0,1330 & 0,0270 & 0,01651 & 0,00061 & 0,1000 & 104,12 & 4,94 & 119,00 & 23,00 & 120,00 & 300,00 \\
\hline AMC-0136-A-26 & 139,00 & 64,70 & 0,47 & 0,05140 & 0,00610 & 0,1180 & 0,0130 & 0,01652 & 0,00047 & 0,1029 & 105,19 & 4,02 & 111,00 & 12,00 & 160,00 & 180,00 \\
\hline AMC-0136-A-23 & 207,00 & 140,00 & 0,68 & 0,06270 & 0,00440 & 0,1461 & 0,0098 & 0,01671 & 0,00029 & 0,0119 & 104,88 & 3,20 & 138,00 & 8,60 & 600,00 & 140,00 \\
\hline AMC-0136-A-3 & 267,00 & 133,80 & 0,50 & 0,05280 & 0,00570 & 0,1230 & 0,0130 & 0,01685 & 0,00041 & 0,0544 & 107,09 & 3,76 & 120,00 & 12,00 & 270,00 & 180,00 \\
\hline AMC-0136-A-10 & 888,00 & 246,00 & 0,28 & 0,05900 & 0,00430 & 0,1370 & 0,0094 & 0,01685 & 0,00037 & 0,0695 & 106,26 & 3,58 & 131,40 & 8,70 & 540,00 & 140,00 \\
\hline AMC-0136-A-25 & 238,00 & 178,00 & 0,75 & 0,05890 & 0,00410 & 0,1368 & 0,0092 & 0,01692 & 0,00026 & 0,0995 & 106,71 & 3,15 & 129,90 & 8,20 & 480,00 & 130,00 \\
\hline AMC-0136-A-22 & 189,00 & 93,30 & 0,49 & 0,05500 & 0,00510 & 0,1300 & 0,0110 & 0,01709 & 0,00041 & 0,1131 & 108,31 & 3,80 & 123,00 & 10,00 & 320,00 & 170,00 \\
\hline AMC-0136-A-4 & 683,00 & 1101,00 & 1,61 & 0,04900 & 0,00290 & 0,1168 & 0,0071 & 0,01716 & 0,00027 & 0,2581 & 109,57 & 3,21 & 111,70 & 6,50 & 160,00 & 110,00 \\
\hline AMC-0136-A-16 & 338,00 & 105,00 & 0,31 & 0,04990 & 0,00450 & 0,1170 & 0,0110 & 0,01730 & 0,00033 & 0,1533 & 110,34 & 3,50 & 110,00 & 9,60 & 140,00 & 160,00 \\
\hline AMC-0136-A-2 & 369,00 & 205,80 & 0,56 & 0,04950 & 0,00440 & 0,1190 & 0,0100 & 0,01731 & 0,00046 & 0,1777 & 110,46 & 4,06 & 113,10 & 9,10 & 140,00 & 150,00 \\
\hline AMC-0136-A-20 & 83,00 & 28,70 & 0,35 & 0,06000 & 0,01000 & 0,1440 & 0,0230 & 0,01757 & 0,00048 & 0,1257 & 110,63 & 4,35 & 124,00 & 20,00 & 270,00 & 260,00 \\
\hline AMC-0136-A-5 & 311,00 & 203,00 & 0,65 & 0,05230 & 0,00540 & 0,1260 & 0,0130 & 0,01764 & 0,00037 & 0,1991 & 112,16 & 3,70 & 122,00 & 12,00 & 250,00 & 170,00 \\
\hline AMC-0136-A-12 & 191,70 & 48,70 & 0,25 & 0,06050 & 0,00720 & 0,1500 & 0,0170 & 0,01799 & 0,00056 & 0,1373 & 113,19 & 4,58 & 143,00 & 14,00 & 470,00 & 200,00 \\
\hline AMC-0136-A-6 & 354,00 & 144,00 & 0,41 & 0,05230 & 0,00430 & 0,1360 & 0,0100 & 0,01800 & 0,00037 & 0,0706 & 114,43 & 3,74 & 127,20 & 9,30 & 320,00 & 150,00 \\
\hline AMC-0136-A-1 & 231,00 & 72,20 & 0,31 & 0,05630 & 0,00520 & 0,1470 & 0,0140 & 0,01836 & 0,00044 & 0,1667 & 116,12 & 4,05 & 139,00 & 12,00 & 360,00 & 160,00 \\
\hline AMC-0136-A-15 & 77,90 & 67,30 & 0,86 & 0,04690 & 0,00660 & 0,2370 & 0,0330 & 0,03477 & 0,00099 & 0,0815 & 221,33 & 8,40 & 215,00 & 26,00 & 80,00 & 210,00 \\
\hline AMC-0136-A-9 & 113,80 & 57,30 & 0,50 & 0,05410 & 0,00500 & 0,3070 & 0,0270 & 0,03960 & 0,00120 & 0,1854 & 249,46 & 10,11 & 269,00 & 21,00 & 310,00 & 170,00 \\
\hline AMC-0136-A-8 & 17,93 & 8,82 & 0,49 & 0,15600 & 0,02300 & 1,0900 & 0,1500 & 0,05230 & 0,00240 & 0,0561 & 287,14 & 17,99 & 712,00 & 73,00 & $1.680,00$ & 320,00 \\
\hline AMC-0136-A-13 & 241,00 & 8,60 & 0,04 & 0,07860 & 0,00210 & 2,1570 & 0,0600 & 0,19610 & 0,00390 & 0,3376 & $1.153,93$ & 35,62 & $1.167,00$ & 20,00 & $1.151,00$ & 53,00 \\
\hline AMC-0136-A-14 & 210,00 & 21,80 & 0,10 & 0,08120 & 0,00190 & 2,5510 & 0,0750 & 0,22880 & 0,00400 & 0,5272 & $1.334,76$ & 39,36 & $1.280,00$ & 21,00 & $1.226,00$ & 49,00 \\
\hline
\end{tabular}


Anexo 1.11. Resultados isotópicos U-Pb en circón de la muestra GZ-6829B

\begin{tabular}{|c|c|c|c|c|c|c|c|c|c|c|c|c|c|c|c|c|}
\hline Punto & $\mathrm{U}(\mathrm{ppm})$ & Th (ppm) & $\mathrm{Th} / \mathrm{U}$ & ${ }^{207} \mathrm{~Pb} /{ }^{206} \mathrm{~Pb}$ & $\pm 2 \sigma$ & $207 \mathrm{~Pb} / 235 \mathrm{U}$ & $\pm 2 \sigma$ & ${ }^{206} \mathrm{~Pb} /{ }^{238} \mathrm{U}$ & $\pm 2 \sigma$ & $\begin{array}{c}\text { Correlación } \\
\text { de errores }\end{array}$ & $\begin{array}{c}\text { Edad }{ }^{206} \mathrm{~Pb} /{ }^{238} \mathrm{U} \\
(\mathrm{Ma})\end{array}$ & $\pm 2 \sigma$ & $\begin{array}{c}\text { Edad }{ }^{207} \mathrm{~Pb} /{ }^{235} \mathrm{U} \\
(\mathrm{Ma})\end{array}$ & $\pm 2 \sigma$ & $\begin{array}{c}\text { Edad } \\
{ }^{207} \mathrm{~Pb} /{ }^{206} \mathrm{~Pb}(\mathrm{Ma})\end{array}$ & $\pm 2 \sigma$ \\
\hline GZ-6829-B-22 & 495,00 & 94,00 & 0,19 & 0,08160 & 0,00500 & 0,1395 & 0,0084 & 0,01221 & 0,00026 & 0,1661 & 74,89 & 2,52 & 129,70 & 7,20 & $1.170,00$ & 110,00 \\
\hline GZ-6829-B-14 & 131,00 & 36,10 & 0,28 & 0,05530 & 0,00740 & 0,1130 & 0,0150 & 0,01503 & 0,00038 & 0,0910 & 95,28 & 3,48 & 103,00 & 13,00 & 210,00 & 210,00 \\
\hline GZ-6829-B-8 & 216,50 & 98,80 & 0,46 & 0,05690 & 0,00460 & 0,1183 & 0,0093 & 0,01506 & 0,00027 & 0,0218 & 95,28 & 2,97 & 111,80 & 8,40 & 430,00 & 140,00 \\
\hline GZ-6829-B-3 & 262,70 & 77,60 & 0,30 & 0,05340 & 0,00550 & 0,1130 & 0,0110 & 0,01511 & 0,00032 & 0,0099 & 96,02 & 3,19 & 106,00 & 10,00 & 220,00 & 180,00 \\
\hline GZ-6829-B-18 & 205,80 & 65,30 & 0,32 & 0,06020 & 0,00510 & 0,1240 & 0,0100 & 0,01523 & 0,00029 & 0,1000 & 95,94 & 3,03 & 117,70 & 9,00 & 480,00 & 150,00 \\
\hline GZ-6829-B-1 & 236,20 & 71,20 & 0,30 & 0,06670 & 0,00600 & 0,1410 & 0,0120 & 0,01527 & 0,00031 & 0,1000 & 95,40 & 3,16 & 134,00 & 11,00 & 710,00 & 170,00 \\
\hline GZ-6829-B-9 & 248,70 & 121,60 & 0,49 & 0,05630 & 0,00390 & 0,1205 & 0,0086 & 0,01530 & 0,00024 & 0,1256 & 96,86 & 2,89 & 114,00 & 7,70 & 410,00 & 130,00 \\
\hline GZ-6829-B-11 & 803,00 & 437,00 & 0,54 & 0,04770 & 0,00200 & 0,0997 & 0,0043 & 0,01530 & 0,00022 & 0,1834 & 97,92 & 2,76 & 96,10 & 4,00 & 103,00 & 81,00 \\
\hline GZ-6829-B-30 & 183,00 & 68,60 & 0,37 & 0,05080 & 0,00540 & 0,1050 & 0,0110 & 0,01535 & 0,00034 & 0,1682 & 97,85 & 3,32 & 102,10 & 9,90 & 190,00 & 170,00 \\
\hline GZ-6829-B-17 & 266,00 & 88,30 & 0,33 & 0,05200 & 0,00450 & 0,1090 & 0,0094 & 0,01537 & 0,00028 & 0,1278 & 97,83 & 3,04 & 104,70 & 8,60 & 260,00 & 160,00 \\
\hline GZ-6829-B-24 & 346,00 & 149,80 & 0,43 & 0,06020 & 0,00340 & 0,1272 & 0,0073 & 0,01538 & 0,00023 & 0,1869 & 96,88 & 2,87 & 122,70 & 6,70 & 540,00 & 110,00 \\
\hline GZ-6829-B-25 & 174,70 & 57,89 & 0,33 & 0,05040 & 0,00400 & 0,1076 & 0,0082 & 0,01543 & 0,00032 & 0,1175 & 98,41 & 3,23 & 103,00 & 7,60 & 230,00 & 140,00 \\
\hline GZ-6829-B-21 & 296,00 & 78,50 & 0,27 & 0,05110 & 0,00340 & 0,1105 & 0,0076 & 0,01559 & 0,00027 & 0,2211 & 99,34 & 3,03 & 105,80 & 6,90 & 220,00 & 120,00 \\
\hline GZ-6829-B-16 & 390,00 & 124,10 & 0,32 & 0,05710 & 0,00360 & 0,1238 & 0,0077 & 0,01576 & 0,00022 & 0,0491 & 99,66 & 2,83 & 118,40 & 6,90 & 440,00 & 120,00 \\
\hline GZ-6829-B-15 & 815,00 & 331,80 & 0,41 & 0,05010 & 0,00220 & 0,1079 & 0,0046 & 0,01578 & 0,00021 & 0,1093 & 100,67 & 2,82 & 104,70 & 4,30 & 185,00 & 84,00 \\
\hline GZ-6829-B-20 & 165,00 & 43,70 & 0,26 & 0,05170 & 0,00480 & 0,1120 & 0,0100 & 0,01590 & 0,00031 & 0,0826 & 101,23 & 3,24 & 108,60 & 9,20 & 230,00 & 160,00 \\
\hline GZ-6829-B-31 & 167,60 & 50,00 & 0,30 & 0,07030 & 0,00660 & 0,1530 & 0,0140 & 0,01591 & 0,00033 & 0,0497 & 98,92 & 3,29 & 145,00 & 12,00 & 740,00 & 180,00 \\
\hline GZ-6829-B-12 & 812,00 & 381,00 & 0,47 & 0,05330 & 0,00240 & 0,1163 & 0,0051 & 0,01595 & 0,00020 & 0,1095 & 101,34 & 2,82 & 111,60 & 4,60 & 333,00 & 88,00 \\
\hline GZ-6829-B-4 & 143,00 & 69,50 & 0,49 & 0,06720 & 0,00940 & 0,1490 & 0,0210 & 0,01622 & 0,00037 & 0,1000 & 101,24 & 3,59 & 134,00 & 18,00 & 650,00 & 240,00 \\
\hline GZ-6829-B-2 & 288,20 & 86,70 & 0,30 & 0,06330 & 0,00450 & 0,1530 & 0,0110 & 0,01761 & 0,00032 & 0,1323 & 110,42 & 3,45 & 143,60 & 9,30 & 560,00 & 140,00 \\
\hline GZ-6829-B-28 & 147,60 & 124,00 & 0,84 & 0,06350 & 0,00370 & 0,2770 & 0,0170 & 0,03115 & 0,00048 & 0,2960 & 194,45 & 5,75 & 245,00 & 14,00 & 650,00 & 120,00 \\
\hline GZ-6829-B-27 & 41,30 & 60,50 & 1,46 & 0,04630 & 0,00630 & 0,1990 & 0,0270 & 0,03129 & 0,00071 & 0,1008 & 199,55 & 7,14 & 182,00 & 23,00 & 40,00 & 200,00 \\
\hline GZ-6829-B-10 & 108,40 & 215,00 & 1,98 & 0,04980 & 0,00410 & 0,2180 & 0,0180 & 0,03128 & 0,00061 & 0,2050 & 198,62 & 6,27 & 194,00 & 15,00 & 130,00 & 150,00 \\
\hline GZ-6829-B-5 & 66,10 & 98,90 & 1,50 & 0,05570 & 0,00620 & 0,2490 & 0,0260 & 0,03295 & 0,00086 & 0,0940 & 207,59 & 7,69 & 222,00 & 22,00 & 280,00 & 190,00 \\
\hline GZ-6829-B-7 & 34,50 & 37,20 & 1,08 & 0,07030 & 0,00970 & 0,3240 & 0,0430 & 0,03311 & 0,00091 & 0,0399 & 204,79 & 7,79 & 266,00 & 33,00 & 520,00 & 260,00 \\
\hline GZ-6829-B-19 & 68,60 & 37,00 & 0,54 & 0,05320 & 0,00630 & 0,2420 & 0,0290 & 0,03390 & 0,00076 & 0,1000 & 214,17 & 7,11 & 223,00 & 22,00 & 240,00 & 190,00 \\
\hline GZ-6829-B-29 & 148,20 & 111,40 & 0,75 & 0,15470 & 0,00900 & 0,8390 & 0,0590 & 0,03901 & 0,00099 & 0,7417 & 215,13 & 8,48 & 605,00 & 31,00 & $2.351,00$ & 98,00 \\
\hline GZ-6829-B-13 & 240,00 & 75,50 & 0,31 & 0,07430 & 0,00270 & 0,6840 & 0,0240 & 0,06780 & 0,00100 & 0,1827 & 413,13 & 11,59 & 532,00 & 15,00 & $1.009,00$ & 77,00 \\
\hline
\end{tabular}


Anexo 2. Resultados de elementos de las tierras raras (REE) en circones de muestras del Batolito de Mogotes

Anexo 2.1. Resultados de elementos traza en los circones de la muestra TCR-376

\begin{tabular}{|c|c|c|c|c|c|c|c|c|c|c|c|c|c|}
\hline Punto/REE en ppm & La & $\mathrm{Ce}$ & $\mathrm{Pr}$ & Nd & Sm & Eu & Gd & $\mathrm{Tb}$ & Dy & Ho & $\mathrm{Er}$ & $\mathrm{Yb}$ & Lu \\
\hline Zircon-141 TCR-376 & 0,86 & 45,5 & 0,188 & 1,47 & 2,29 & 0,89 & 13,22 & 4,55 & 59,2 & 23,73 & 115,4 & 266,8 & 57,67 \\
\hline Zircon-142 & 0,391 & 23,72 & 0,203 & 1,38 & 1,54 & 0,54 & 7,27 & 2,47 & 31,4 & 13,39 & 67,4 & 163 & 35,46 \\
\hline Zircon-143 & 0 & 4,43 & 0,026 & 0,72 & 1,91 & 0,32 & 12,85 & 4,63 & 62,3 & 25,19 & 118,3 & 233,1 & 49 \\
\hline Zircon-144 & 0 & 16,1 & 0,0037 & 0,26 & 0,7 & 0,314 & 4,8 & 2,05 & 27,3 & 11,8 & 60,5 & 151 & 35,9 \\
\hline Zircon-145 & 6,5 & 43,4 & 0,64 & 2,5 & 1,34 & 0,8 & 12,4 & 4,55 & 58,9 & 26,01 & 128,3 & 287,1 & 61,5 \\
\hline Zircon-146 & 0 & 43,23 & 0,046 & 1,05 & 2,76 & 0,8 & 14,51 & 5,51 & 70,9 & 30,68 & 153,8 & 367,6 & 81,4 \\
\hline Zircon-147 & 0,012 & 26,7 & 0,035 & 0,47 & 1,4 & 0,59 & 10,06 & 4,16 & 54,7 & 24,57 & 123,2 & 308,5 & 72,5 \\
\hline Zircon-148 & 0,108 & 65,7 & 1,051 & 15,6 & 21 & 7,44 & 77,2 & 21,9 & 231 & 81,1 & 337 & 630 & 126,5 \\
\hline Zircon-149 & 0,085 & 80,9 & 0,48 & 9 & 14,1 & 4,47 & 67,3 & 20,9 & 238 & 88,6 & 377 & 697 & 132,5 \\
\hline Zircon-150 & 0 & 58,9 & 0,085 & 1,41 & 2,99 & 1,35 & 20,8 & 7,69 & 95,3 & 39,62 & 187,5 & 408,6 & 87,6 \\
\hline Zircon-151 & 0,244 & 44,65 & 0,117 & 1,42 & 2,94 & 1,14 & 17,95 & 6,71 & 87,1 & 37,69 & 186,9 & 435,3 & 96,9 \\
\hline Zircon-152 & 0 & 11,07 & 0,0084 & 0,38 & 0,77 & 0,319 & 3,61 & 1,39 & 17,77 & 7,46 & 36,1 & 92 & 20,65 \\
\hline Zircon-153 & 0 & 148,7 & 0,137 & 3,13 & 9,04 & 2,75 & 47,2 & 16,7 & 200 & 74,9 & 341 & 674 & 132,1 \\
\hline Zircon-154 & 0,106 & 29,5 & 0,076 & 1,48 & 2,5 & 1,03 & 15,6 & 5,7 & 68 & 27,8 & 130 & 291 & 61,9 \\
\hline Zircon-155 & 0,267 & 48,9 & 0,137 & 1,43 & 3,26 & 1,31 & 18,7 & 7,38 & 94,7 & 40,5 & 199,9 & 484,9 & 105,3 \\
\hline Zircon-156 & 0 & 46,7 & 0,098 & 2,39 & 3,72 & 1,45 & 19,3 & 6,58 & 82,3 & 34 & 161 & 371 & 81,9 \\
\hline Zircon-157 & 0,045 & 14,64 & 0,086 & 0,8 & 1,76 & 0,165 & 7,5 & 3,41 & 42,8 & 19 & 97,2 & 272,9 & 60,2 \\
\hline Zircon-158 & 0,125 & 52,3 & 0,273 & 3,47 & 6,73 & 2,18 & 31,7 & 10,55 & 123 & 50,3 & 231 & 525 & 112,2 \\
\hline Zircon-159 & 0,33 & 51,3 & 0,461 & 6,43 & 9,81 & 2,81 & 37,4 & 11,55 & 129,6 & 49,7 & 219,6 & 469 & 99,4 \\
\hline Zircon-160 & 221 & 710 & 88 & 420 & 98 & 14,7 & 126 & 28,4 & 269 & 89 & 348 & 636 & 121,2 \\
\hline Zircon-161 & 4,3 & 67,7 & 1,64 & 8,2 & 5,83 & 1,72 & 24,2 & 8,54 & 100,9 & 42,2 & 193,2 & 418 & 88,3 \\
\hline Zircon-162 & 19,3 & 131 & 6 & 33 & 10,7 & 2,38 & 32 & 11,33 & 132,4 & 52,9 & 234 & 504 & 100,8 \\
\hline Zircon-163 & 0,027 & 77 & 0,295 & 6,29 & 12,34 & 3,72 & 58,4 & 19,98 & 225 & 84 & 363 & 703 & 137,1 \\
\hline Zircon-164 & 6,53 & 101,2 & 3,94 & 20,5 & 11,6 & 2,67 & 37,3 & 13,5 & 158,2 & 62,9 & 290 & 684 & 149,5 \\
\hline Zircon-165 & 0,0052 & 50,37 & 0,167 & 3,26 & 5,1 & 2,28 & 24,7 & 8,71 & 115,3 & 51,9 & 247,3 & 554,2 & 117,8 \\
\hline Zircon-166 & 0,034 & 78,3 & 0,325 & 6,05 & 8,81 & 3,17 & 45,1 & 14,71 & 159,8 & 58,3 & 239,3 & 441,7 & 83,8 \\
\hline Zircon-001 TCR-376 & 0,09 & 120,6 & 0,245 & 3,31 & 7,4 & 2,25 & 40,7 & 13,01 & 154,9 & 57,4 & 254 & 502 & 101,2 \\
\hline Zircon-002 & 0 & 68,8 & 0,112 & 1,96 & 4,33 & 1,52 & 24,15 & 8,38 & 97,6 & 38,38 & 177,9 & 354,8 & 74,1 \\
\hline Zircon-003 & 0,26 & 26,69 & 0,072 & 0,79 & 1,43 & 0,503 & 8,07 & 2,94 & 38,6 & 16,55 & 87,2 & 212 & 48,6 \\
\hline Zircon-004 & 0,0037 & 39,9 & 0,362 & 5,56 & 9,09 & 3,14 & 38,8 & 11,64 & 131,9 & 47 & 207,1 & 388 & 80,3 \\
\hline Zircon-005 & 0,135 & 424 & 1,6 & 25,2 & 41,6 & 10,59 & 184,6 & 54,2 & 606 & 217 & 911 & 1.540 & 293 \\
\hline Zircon-006 & 5,9 & 67,8 & 1,56 & 7,9 & 4,23 & 1,33 & 21,2 & 7,38 & 96,4 & 40,3 & 204,7 & 468 & 106,9 \\
\hline Zircon-007 & 0,07 & 222 & 0,349 & 6,34 & 11,69 & 4,22 & 61,9 & 18,9 & 208 & 73 & 327 & 579 & 117,3 \\
\hline Zircon-008 & 0 & 31,3 & 0,027 & 0,95 & 1,82 & 0,67 & 9,76 & 3,58 & 44 & 17,6 & 88,9 & 196 & 43,5 \\
\hline Zircon-009 TCR-376 & 0,07 & 112,3 & 0,14 & 3,03 & 6,46 & 2,42 & 39,1 & 13,07 & 156,1 & 59,5 & 272,8 & 554 & 115,8 \\
\hline
\end{tabular}


Anexo 2.2. Resultados de elementos traza en los circones de la muestra MIA-638

\begin{tabular}{|c|c|c|c|c|c|c|c|c|c|c|c|c|c|}
\hline Punto/REE en ppm & La & $\mathrm{Ce}$ & $\mathrm{Pr}$ & Nd & $\mathrm{Sm}$ & $\mathrm{Eu}$ & Gd & Tb & Dy & Ho & $\mathrm{Er}$ & $\mathbf{Y b}$ & Lu \\
\hline Zircon-071 MIA-638 & 0,25 & 103 & 0,193 & 2,8 & 9,5 & 1,01 & 87 & 39,8 & 542 & 226 & 1.050 & 2.080 & 418 \\
\hline Zircon-072 & 0 & 48,7 & 0,028 & 0,59 & 2,44 & 0,78 & 16,4 & 6,99 & 95 & 41,8 & 216 & 493 & 105 \\
\hline Zircon-073 & 0,4 & 254 & 0,41 & 7,9 & 16,6 & 5 & 91 & 30,4 & 364 & 140 & 610 & 1130 & 226 \\
\hline Zircon-074 & 5,8 & 338 & 7,2 & 82 & 95 & 27,2 & 301 & 86 & 870 & 290 & 1.170 & 1.920 & 360 \\
\hline Zircon-075 & 48 & 119 & 8,6 & 31,9 & 6,9 & 1,3 & 24,7 & 9,1 & 118 & 50,5 & 233 & 550 & 119 \\
\hline Zircon-076 & 0,067 & 102 & 0,211 & 3,36 & 6,6 & 1,72 & 35,3 & 11,8 & 140 & 55,3 & 249 & 515 & 106 \\
\hline Zircon-077 & 0,109 & 116 & 0,62 & 9,9 & 16,5 & 4,24 & 77 & 25,4 & 295 & 111 & 491 & 910 & 185 \\
\hline Zircon-078 & 12,7 & 480 & 4,3 & 29,1 & 30,9 & 8,1 & 183 & 62 & 700 & 250 & 1.040 & 1.650 & 310 \\
\hline Zircon-079 & 0,47 & 18,1 & 0,272 & 2,9 & 4,9 & 0,71 & 22,7 & 7,4 & 85 & 32 & 150 & 308 & 67 \\
\hline Zircon-080 & 5,8 & 58,4 & 1,58 & 7,8 & 4 & 1,02 & 16,3 & 5,48 & 70,6 & 31,2 & 151 & 352 & 78 \\
\hline Zircon-081 & 2,05 & 77 & 0,82 & 7,2 & 8,4 & 3,08 & 41,7 & 13,1 & 152 & 58 & 270 & 560 & 120 \\
\hline Zircon-082 & 1,6 & 179 & 1,32 & 13,7 & 18,3 & 5,7 & 83 & 29 & 325 & 123 & 520 & 910 & 177 \\
\hline Zircon-083 & 0,044 & 59 & 0,191 & 4,55 & 7,8 & 1,42 & 38,4 & 11,4 & 120 & 42,6 & 168 & 329 & 64 \\
\hline Zircon-084 & 1,97 & 43,1 & 0,82 & 3,6 & 3,31 & 0,78 & 14,7 & 5,6 & 72 & 30,5 & 147 & 333 & 71 \\
\hline Zircon-085 & 4,2 & 66 & 1,21 & 5,8 & 4,1 & 1,04 & 16,8 & 7,2 & 96 & 40 & 192 & 381 & 93 \\
\hline Zircon-086 & 0,265 & 689 & 1,15 & 22,7 & 46,7 & 11,8 & 255 & 85 & 960 & 352 & 1.460 & 2.320 & 437 \\
\hline Zircon-087 & 0,7 & 81 & 0,84 & 7,3 & 13,4 & 3,64 & 47,8 & 15,7 & 181 & 67,1 & 300 & 553 & 114 \\
\hline Zircon-088 & 0,211 & 45,7 & 0,107 & 1,15 & 2,79 & 0,92 & 15,4 & 5,82 & 74,7 & 31,2 & 149 & 328 & 71,5 \\
\hline Zircon-089 & 0,023 & 47,9 & 0,048 & 0,93 & 2,62 & 1,06 & 17,1 & 7 & 91 & 40,8 & 200 & 440 & 97 \\
\hline Zircon-090 & 0,25 & 192 & 0,285 & 3,51 & 10,2 & 2,73 & 51,6 & 18,3 & 225 & 87,7 & 405 & 820 & 167 \\
\hline Zircon-091 & 0,03 & 1,57 & $-0,00000099$ & 0,058 & 0,43 & 0,18 & 6,2 & 4,2 & 64 & 28,1 & 143 & 310 & 66 \\
\hline Zircon-92 & 0,014 & 7,16 & 0,041 & 0,75 & 1,16 & 0,318 & 4,67 & 1,34 & 16,8 & 5,87 & 26,2 & 59,1 & 15,2 \\
\hline Zircon-93 & 0,51 & 127 & 0,89 & 14,4 & 18,3 & 5,88 & 84 & 27,2 & 300 & 110 & 457 & 830 & 170 \\
\hline Zircon-94 & 1,67 & 70 & 0,64 & 3,9 & 4,17 & 1,08 & 24,8 & 8,9 & 110 & 46,8 & 228 & 482 & 103 \\
\hline Zircon-95 & 12,8 & 140 & 5,2 & 31,6 & 22,1 & 2,48 & 111 & 36,9 & 437 & 163 & 711 & 1240 & 245 \\
\hline Zircon-96 & 0,35 & 85,1 & 0,4 & 4,75 & 10,5 & 3,46 & 66,3 & 25 & 305 & 118 & 518 & 900 & 178 \\
\hline Zircon-97 & 0,082 & 17 & 0,129 & 0,73 & 1,45 & 0,466 & 9,5 & 3,45 & 45,1 & 19,7 & 98 & 274 & 67,8 \\
\hline Zircon-98 & 0,128 & 1,5 & 0,13 & 0,9 & 2,65 & 0,163 & 23,4 & 12,2 & 188 & 90 & 490 & 1120 & 232 \\
\hline Zircon-99 & 0,037 & 136 & 0,396 & 6,4 & 9,5 & 4,28 & 48,1 & 16,2 & 185 & 78 & 349 & 750 & 156 \\
\hline Zircon-100 & 4,7 & 460 & 3 & 25,7 & 29,7 & 7 & 127 & 41,3 & 460 & 169 & 730 & 1290 & 255 \\
\hline Zircon-101 & 1,49 & 216 & 0,98 & 10,8 & 19,4 & 6,49 & 100,2 & 32,7 & 365 & 132 & 556 & 1040 & 207 \\
\hline Zircon-102 & 3,8 & 447 & 1,85 & 17,8 & 30,4 & 6,5 & 138 & 47,8 & 530 & 196 & 860 & 1560 & 310 \\
\hline Zircon-103 MIA-638 & 0,025 & 95 & 0,126 & 2,33 & 5,52 & 1,7 & 36,6 & 13 & 169 & 66,6 & 334 & 687 & 140 \\
\hline
\end{tabular}


Anexo 2.3. Resultados de elementos traza en los circones de la muestra MIA-636

\begin{tabular}{|c|c|c|c|c|c|c|c|c|c|c|c|c|c|}
\hline$z$ & La & $\mathrm{Ce}$ & $\mathrm{Pr}$ & Nd & $\mathrm{Sm}$ & $\mathrm{Eu}$ & Gd & Tb & Dy & Ho & $\mathrm{Er}$ & $\mathrm{Yb}$ & Lu \\
\hline Zircon-068 MIA-636 & 0,092 & 27,4 & 0,096 & 1,44 & 2,94 & 0,98 & 14,9 & 5,13 & 62,2 & 23,9 & 115 & 244 & 50,3 \\
\hline Zircon-069 & 0,01 & 43,2 & 0,074 & 2,04 & 4,75 & 1,63 & 22,9 & 7,3 & 87 & 34 & 155 & 294 & 60,6 \\
\hline Zircon-070 & 0,26 & 80 & 0,56 & 9,8 & 15,9 & 4,55 & 84 & 26,6 & 299 & 105 & 469 & 800 & 152 \\
\hline Zircon-071 & 35 & 116 & 10,7 & 52 & 12,1 & 2,05 & 28,5 & 8,2 & 95 & 34,9 & 165 & 325 & 68,6 \\
\hline Zircon-072 & 0,054 & 105 & 0,22 & 4,05 & 10,5 & 2,74 & 65,7 & 24,1 & 314 & 120 & 554 & 1.020 & 200 \\
\hline Zircon-073 & 0,112 & 27,5 & 0,079 & 1,38 & 3,23 & 0,623 & 18,6 & 6,97 & 83 & 32,1 & 158 & 348 & 73,2 \\
\hline Zircon-074 & 0,087 & 77 & 0,111 & 1,79 & 4,58 & 1,42 & 33,2 & 12,8 & 167 & 68 & 324 & 650 & 130 \\
\hline Zircon-075 & 0,5 & 42,9 & 0,59 & 6,8 & 11,5 & 3,76 & 52,9 & 16,8 & 187 & 67 & 303 & 554 & 111 \\
\hline Zircon-076 & 0,025 & 43,2 & 0,1 & 1,89 & 4,39 & 1,68 & 25 & 9,57 & 117 & 45,2 & 219 & 446 & 90,8 \\
\hline Zircon-077 & 0,0091 & 66 & 0,107 & 2,61 & 5,19 & 1,58 & 30,8 & 10,9 & 129 & 48,6 & 223 & 404 & 79,9 \\
\hline Zircon-078 & 0,25 & 55,1 & 0,229 & 3,49 & 5,67 & 2,07 & 33,9 & 11,8 & 152 & 61,1 & 273 & 556 & 116 \\
\hline Zircon-079 & 0 & 8,4 & 0,036 & 0,73 & 1,63 & 0,68 & 9 & 3,21 & 36,8 & 14,7 & 65,9 & 123 & 25,4 \\
\hline Zircon-080 & 0,0015 & 19 & 0,148 & 2,66 & 4,95 & 1,7 & 25,8 & 8,14 & 94 & 34,6 & 152 & 273 & 57,4 \\
\hline Zircon-081 & 0,072 & 41,6 & 0,078 & 1,16 & 2,97 & 0,99 & 20,8 & 7,13 & 95 & 38,2 & 181 & 375 & 77,1 \\
\hline Zircon-082 & 0,092 & 72,6 & 0,138 & 1,93 & 5,39 & 1,45 & 33,2 & 13,4 & 172 & 65,8 & 302 & 563 & 110 \\
\hline Zircon-083 & 0,044 & 32,8 & 0,416 & 5,82 & 9,2 & 3,44 & 38,5 & 11,3 & 120 & 44,1 & 198 & 359 & 76,3 \\
\hline Zircon-084 & 0,024 & 29,7 & 0,075 & 1,7 & 3,73 & 1,24 & 19,4 & 7,3 & 86,9 & 35,7 & 167 & 357 & 75,3 \\
\hline Zircon-085 & 0,035 & 30,5 & 0,028 & 1,34 & 2,74 & 0,78 & 18,8 & 7,4 & 97,1 & 39,6 & 197 & 408 & 85 \\
\hline Zircon-086 & 0 & 13,3 & 0,066 & 0,93 & 2,36 & 0,126 & 14 & 5,17 & 60,1 & 22,6 & 100,9 & 178 & 34,9 \\
\hline Zircon-087 & 0,87 & 77,9 & 0,55 & 3,53 & 8,2 & 1,63 & 49,6 & 20,4 & 254 & 103 & 466 & 867 & 170 \\
\hline Zircon-088 & 4,1 & 88,5 & 1,66 & 10,9 & 11 & 2,57 & 57,1 & 19,7 & 232 & 86 & 375 & 645 & 125 \\
\hline Zircon-089 & 17,3 & 72 & 5,6 & 25,2 & 5,8 & 1,01 & 13 & 3,77 & 42,7 & 17,2 & 87,9 & 226 & 52,1 \\
\hline Zircon-090 & 0,57 & 63,8 & 0,34 & 3,43 & 6,05 & 1,99 & 32,7 & 11,04 & 132,6 & 50,6 & 237 & 456 & 93,2 \\
\hline Zircon-091 & 0,079 & 72,2 & 0,136 & 2,95 & 5,5 & 2,58 & 35,6 & 12,7 & 160 & 62,3 & 293 & 563 & 116 \\
\hline Zircon-92 & 1,03 & 46,2 & 0,62 & 4,9 & 10,6 & 1,5 & 54,9 & 19,9 & 255 & 95,7 & 456 & 821 & 159 \\
\hline Zircon-93 & 0,47 & 42 & 0,48 & 7,01 & 12,2 & 3,85 & 57,2 & 18,6 & 206 & 72,1 & 307 & 510 & 99 \\
\hline Zircon-94 & 0,033 & 87,1 & 0,138 & 2,29 & 9,1 & 1,68 & 75,1 & 27,6 & 356 & 136 & 618 & 1.130 & 217 \\
\hline Zircon-95 & 0,67 & 104 & 1,16 & 15,9 & 23,6 & 9,5 & 121 & 38 & 410 & 148 & 620 & 1.090 & 208 \\
\hline Zircon-96 & 0,077 & 155 & 0,14 & 2,94 & 10,9 & 1,89 & 75,8 & 29,8 & 405 & 158 & 738 & 1.350 & 257 \\
\hline Zircon-97 & 0,096 & 65,6 & 0,284 & 4,32 & 7,09 & 2,62 & 39,8 & 12,7 & 154 & 57,3 & 260 & 480 & 96,7 \\
\hline Zircon-98 & 0,078 & 52 & 0,259 & 4,77 & 8,9 & 2,79 & 43,3 & 14,3 & 165 & 62 & 277 & 494 & 100,3 \\
\hline Zircon-99 & 11,8 & 62 & 5,7 & 24,6 & 18,7 & 4,19 & 50,7 & 16,9 & 197 & 68,9 & 301 & 595 & 119 \\
\hline Zircon-100 & 0,0019 & 16 & 0,113 & 2,39 & 4,02 & 1,88 & 21,6 & 7,14 & 80,2 & 30,1 & 140 & 260 & 55,1 \\
\hline Zircon-101 & 9,2 & 70,7 & 2,64 & 15,7 & 6,9 & 1,72 & 26,4 & 9,3 & 113 & 45,1 & 210 & 412 & 84,9 \\
\hline Zircon-102 MIA-636 & 0,182 & 4,15 & 0,081 & 0,46 & 1,14 & 0,125 & 4,9 & 2,42 & 26,6 & 12 & 55,3 & 141 & 32,6 \\
\hline
\end{tabular}


Anexo 2.4. Resultados de elementos traza en los circones de la muestra AMC-0144

\begin{tabular}{|c|c|c|c|c|c|c|c|c|c|c|c|c|c|}
\hline Punto/REE en ppm & La & $\mathrm{Ce}$ & $\mathrm{Pr}$ & Nd & $\mathrm{Sm}$ & Eu & Gd & Tb & Dy & Ho & $\mathrm{Er}$ & $\mathrm{Yb}$ & Lu \\
\hline Zircon-001 AMC-0144 & 0,000000279 & 39,5 & 0,083 & 1,71 & 3,04 & 1,2 & 19 & 6,27 & 79,1 & 32,3 & 162 & 378 & 84 \\
\hline Zircon-008 & 1,68 & 40,1 & 0,5 & 3,9 & 4,7 & 1,53 & 21,5 & 7,7 & 91 & 35,5 & 166 & 353 & 76 \\
\hline Zircon-013 & 0,00000036 & 40 & 0,007 & 0,87 & 2,21 & 0,94 & 12,1 & 5,7 & 77 & 34,7 & 187 & 490 & 114 \\
\hline Zircon-014 & 0,0078 & 46,8 & 0,063 & 0,98 & 2,65 & 0,956 & 15,34 & 5,91 & 77 & 31,3 & 155,4 & 350 & 74,6 \\
\hline Zircon-015 & 0,000000198 & 50,4 & 0,047 & 1,34 & 2,99 & 1,11 & 17,8 & 6,49 & 88 & 36,7 & 186 & 438 & 99,9 \\
\hline Zircon-016 & 0,055 & 75 & 0,7 & 9,7 & 16,2 & 5,2 & 66,2 & 19,5 & 218 & 76 & 336 & 625 & 125 \\
\hline Zircon-017 & 0,000000227 & 39,9 & 0,068 & 1,11 & 2,4 & 1,08 & 16,9 & 6,14 & 74,7 & 31 & 155 & 350 & 72,1 \\
\hline Zircon-018 & 0,077 & 21 & 0,26 & 7 & 14,9 & 1,3 & 88 & 31 & 380 & 133 & 580 & 1.040 & 210 \\
\hline Zircon-019 & 0,1 & 150 & 0,23 & 0,42 & 7,5 & 4,4 & 80 & 21 & 340 & 130 & 590 & 1.500 & 320 \\
\hline Zircon-020 & 0,000000164 & 18,1 & 0,0159 & 0,38 & 1,21 & 0,451 & 8,24 & 3,06 & 38 & 14,8 & 76,1 & 184 & 42,1 \\
\hline Zircon-023 & 0,0092 & 37,6 & 0,041 & 0,86 & 1,94 & 0,83 & 12,7 & 4,57 & 60,5 & 24,7 & 129 & 332 & 79 \\
\hline Zircon-024 & 0,46 & 93 & 0,69 & 8,9 & 12,8 & 3,91 & 55,9 & 18,1 & 203 & 71 & 329 & 629 & 125 \\
\hline Zircon-026 & 3,9 & 84,9 & 1,08 & 6,4 & 5,31 & 1,73 & 27,3 & 9,62 & 123 & 46,9 & 250 & 529 & 114,3 \\
\hline Zircon-027 & 0,188 & 55,6 & 0,365 & 6 & 9,1 & 3,23 & 41,6 & 13,7 & 155 & 55,2 & 265 & 552 & 115 \\
\hline Zircon-028 & 0,000000108 & 27,4 & 0,029 & 0,78 & 1,79 & 0,502 & 9,96 & 3,66 & 51,6 & 21 & 111 & 278 & 63,1 \\
\hline Zircon-029 & 0,024 & 91 & 0,285 & 6,1 & 10,3 & 3,26 & 51 & 17,2 & 204 & 74,5 & 371 & 781 & 164 \\
\hline Zircon-030 & 0,00000018 & 71 & 0,106 & 2,22 & 4,76 & 1,68 & 28,3 & 10,2 & 130 & 50,4 & 251 & 540 & 113 \\
\hline Zircon-031 & 0,016 & 38,8 & 0,0163 & 0,63 & 2,07 & 0,81 & 13,7 & 5,49 & 74 & 31,1 & 164 & 405 & 90,9 \\
\hline Zircon-032 & 11 & 68 & 2,61 & 9,7 & 3,03 & 0,85 & 14 & 5,33 & 71,3 & 28,1 & 158 & 383 & 88 \\
\hline Zircon-033 & 0,0101 & 40,7 & 0,061 & 1,62 & 3,8 & 1,5 & 23 & 8 & 103 & 38,8 & 194 & 429 & 90,6 \\
\hline Zircon-035 AMC-0144 & 1,06 & 107 & 0,425 & 4,62 & 7 & 2,49 & 37,4 & 12,6 & 153 & 55,7 & 265 & 541 & 110 \\
\hline
\end{tabular}

